\title{
Hoverfly Communities in Semi-Natural Grasslands, and their Role in Pollination
}

\author{
Lucas, Andrew M.
}

How to cite:

Lucas, Andrew M. (2017) Hoverfly Communities in Semi-Natural Grasslands, and their Role in Pollination. Doctoral thesis, Swansea University.

http://cronfa.swan.ac.uk/Record/cronfa40892

Use policy:

This item is brought to you by Swansea University. Any person downloading material is agreeing to abide by the terms of the repository licence: copies of full text items may be used or reproduced in any format or medium, without prior permission for personal research or study, educational or non-commercial purposes only. The copyright for any work remains with the original author unless otherwise specified. The full-text must not be sold in any format or medium without the formal permission of the copyright holder. Permission for multiple reproductions should be obtained from the original author.

Authors are personally responsible for adhering to copyright and publisher restrictions when uploading content to the repository.

Please link to the metadata record in the Swansea University repository, Cronfa (link given in the citation reference above.)

http://www.swansea.ac.uk/library/researchsupport/ris-support/ 


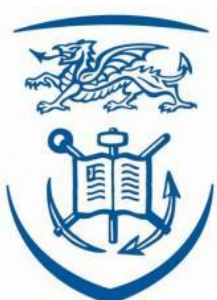

Swansea University Prifysgol Abertawe

\title{
HOVERFLY COMMUNITIES IN SEMI-NATURAL GRASSLANDS, \\ AND THEIR ROLE IN POLLINATION
}

\author{
Mr Andrew Lucas
}

(BSc Ecology)

A thesis submitted to the College of Science in fulfilment for the degree of Doctor of Philosophy from Swansea University.

November, 2017 



\section{DECLARATION}

This work has not previously been accepted in substance for any degree and is not being concurrently submitted in candidature for any degree.

Signed

(candidate)

Date

This thesis is the result of my own investigations, except where otherwise stated. Reference sections are appended.

Other sources are acknowledged by footnotes giving explicit references. A bibliography is appended.

Signed (candidate)

Date

I hereby give consent for my thesis, if accepted, to be available for photocopying and for inter-library loan, and for the title and summary to be made available to outside organisations.

Signed (candidate)

Date 


\section{Contents}

Acknowledgements

Abstract

vi

List of Figures

vii

List of Tables

$x$

List of Abbreviations

xii

Foreword

Chapter 1

GENERAL INTRODUCTION: A

Background to Ecosystem Services,

Pollination, Hoverflies, and

potential applications of DNA

Barcoding

Chapter 2

Flower resource and land

85

management drives hoverfly

communities and bee abundance in

semi-natural and agricultural

grasslands

Chapter 3

Timing of peak emergence and

influence of temperature and

rainfall on hoverfly populations in

fen-meadow grasslands.

Chapter 4

A reference library of CO1 DNA

barcodes for British Syrphidae 
Chapter 5

Generalisation and specialisation in

195

hoverfly (Syrphidae) grassland

pollen transport networks revealed

by DNA metabarcoding.

Chapter 6

Floral resource partitioning by

228

individuals within generalised

hoverfly pollination networks

revealed by DNA metabarcoding

Chapter 7

Discussion

263

Appendices

284 


\section{Acknowledgements}

Firstly, I would like to thank my supervisors, Dr Dan Forman and Dr Penny Neyland (Swansea University) and Dr Natasha de Vere (National Botanic Garden of Wales and Aberystwyth University) for their guidance and support. They reigned in my enthusiasm, tactfully corrected my many errors, and told me things were going fine even when I thought they weren't. I could not have wished for a better supervisory team.

Science is not a solitary endeavour, and I am very grateful for the support of all my collaborators on various chapters. Dr Jim Bull and Dr Owen Bodger gave excellent input with statistics, without which I would still be struggling with R. Dr Matt Hegarty ran the Illumina MiSeq pollen DNA sequencing at IBERS. Dr Berry Brosi gave invaluable advice on the pollen metabarcoding work and network analysis that significantly improved early drafts. Col Ford designed the bioinformatics that produced the data on which much of this thesis is based. He also turned my amateurish excel graphs into quality publishable figures, and patiently endured endless requests for 'just one more minor change'.

Carolyn Greig and Laura Jones had the unenviable task of introducing this clumsy old field ecologist to the precision of molecular biology. Thank you so much for your patience, which was sorely tried at times!

Val Godwin and Mark Rees cast an expert proof-reading eye over the text, picking up many errors and significantly improving my writing in the process.

I would also like to thank all the landowners who allowed me to chase hoverflies across their land, in particular Kyra Somerfield and her late husband Nick at Cruglas, whose connections with the farming community opened many doors. Thanks also to Geoff and 
Sue Freeman at Treiorwg, especially for all those cups of tea at the end of a day's fieldwork.

My employer, the Countryside Council for Wales (now Natural Resources Wales) was very helpful in allowing me to go part time to start my PhD. Roger Thomas (then Chief Executive of CCW) and Dr David Parker (then CCW Chief Scientist) immediately encouraged me and, to my surprise, helped arrange for CCW to meet part of my fees. I have also been incredibly fortunate in my line managers; thanks to Charlotte Gjerlov, David Mee, Dave Charlesworth, Ioan Williams, Huwel Manley and the late David Mitchell for their support. I would also like to thank my colleagues in NRW particularly Khalid Aazem, Richard Facey, Emma Keenan, Brian Pawson, Mair Rees, Leila Thornton, Sue Westwood, Karen Wilkinson, and Julian Woodman - who proof read chapters, and from whose friendship, expertise, and wisdom I benefit daily.

A part-time $\mathrm{PhD}$ of over six years takes a toll on families. Thanks to my wife Beth, and my children Rhiannon and Robert who have grown to adulthood in the course of this work. They all endured the trials and tribulations, particularly during the last few months. We can now finally stop using the phrase "when the $\mathrm{PhD}$ is over..." and get back to our lives! This has been a team effort, and I'd be nowhere without you.

This thesis is dedicated to my parents, Bob and Joyce Lucas, who ignored my headmaster's advice and encouraged my interest in natural history. 


\section{Abstract}

Pollination is an ecosystem service critical to both crop production and the functioning of many ecosystems. Hoverflies (Syrphidae) are a key group of non-hymenopteran pollinators. Using a combination of field and molecular techniques, this thesis explored hoverfly communities in grasslands, investigating how they are structured, and their possible role in pollination. In addition, it also created a library of hoverfly DNA barcodes that has applications for monitoring. Hoverfly abundance and species richness was not related to grassland plant community, but was influenced by flower abundance. Distinctive hoverfly communities were also associated with agriculturally unimproved grassland communities. Focussing on species-rich marshy grasslands, a four year study showed that hoverfly abundance and species richness was influenced by weather conditions. Hoverfly abundance was at a maximum at a daily mean temperature of $15^{\circ} \mathrm{C}$ and at moderate rainfall, declining with both high and low temperature and rainfall. Species-richness declined with increasing daily temperature. Sequences of the standard animal barcode COI were obtained from 82 hoverfly species caught in Britain. This was added to world-wide publicly available sequences for British species to create a library of over $70 \%$ of the British hoverfly fauna. These barcodes were effective at distinguishing hoverfly species, although discrimination was poor in a small number of genera. By DNA metabarcoding pollen derived from hoverflies, the structure of hoverfly pollen transport networks in marshy grasslands was investigated. In Eristalis species, networks were generalised at the whole network and species level, but showed some specialisation by individual hoverflies. Networks of 11 hoverfly species showed that although pollen carried by hoverflies came from a few common plant taxa, different hoverfly species carried distinctive pollen loads derived from at least $40 \%$ of the entomophilous plants present. Collectively, these results increase our understanding of hoverfly community function, and their role in grassland ecosystems. 


\section{List of Figures}

Chapter One Page

Figure 1 The linkages between ecosystem services and human well-being. $\quad 2$ From MEA (2005)

Figure 2 Changing views of nature conservation, from Mace (2014) 7

Figure 3 Change in the distribution of UK pollinators, 1980 to 2010 (JNCC 12 2016).

Figure 4 Eristalis tenax and (inset) wing venation showing the vena spuria $\quad 20$

$\begin{array}{ll}\text { Figure } 5 \text { Cheilosia pagana. } & 23\end{array}$

Figure 6 Hoverfly Eupeodes corollae on flower of Oxalis pes-caprae 24

Figure 7 Pollinator generalisation and specialisation at different levels of $\quad 31$ organisation.

\section{Chapter 2}

Figure 1 Sample Site Locations in South Wales, UK. 90

Figure 2 Percentage of flower units from plant species contributing more than 97 $5 \%$ of total flower unit score in four grassland communities

Figure 3 Canonical Correspondence Analysis biplot of hoverfly communities 103 assessed using pan traps during 2011 at four grassland habitats

Figure 4 Canonical Correspondence Analysis biplot of hoverfly species assessed using pan traps during 2011 at four grassland habitats

\section{Chapter 3}

Figure 1 Location of Field sites used in this study.

Figure 2 Generalised additive model of effect of ordinal date on hoverfly abundance at three marshy grasslands (LLC, RHC and TRE) in west Wales, UK, between 2011 and 2014. Black line = mean model prediction, grey shading $=$ standard error. 
Figure 3 Generalised additive model of effect of insolation ('Sun (hours)') on hoverfly abundance at marshy grassland site TRE in west Wales, UK, between 2011 and 2014.

Figure 4 Generalised additive model of effect of temperature on hoverfly abundance at two marshy grassland sites (CAD and LLC) in west Wales, UK, between 2011 and 2014.

Figure 5 Generalised additive model of effect of mean rainfall $(\mathrm{mm})$ on 138 hoverfly abundance at four marshy grassland sites combined in west Wales, UK, between 2011 and 2014.

Figure 6 Generalised additive model of effect of ordinal date on hoverfly species richness at three marshy grassland (LLC, RHC and TRE) in west Wales, UK, between 2011 and 2014. Black line = mean model prediction, grey shading $=$ standard error .

Figure 7 Generalised additive model of effect of insolation ('Sun (hours)') on hoverfly species richness at marshy grassland RHC in west Wales, UK, between 2011 and 2014.

Figure 8 Generalised additive model of effect of mean daily temperature ('Tmean (Celsius)') on hoverfly species richness at two marshy grasslands (LLC and RHC) in west Wales, UK, between 2011 and 2014.

Figure 9 Generalised additive model of effect of Ln daily rainfall $(\mathrm{mm})$ on hoverfly species richness at marshy grasslands LLC in west Wales, UK, between 2011 and 2014.

\section{Chapter 4}

Figure 1 Distribution map of specimens of Syrphidae sampled in this study

Figure 2 Frequency histogram of intraspecific and interspecific K2P distances 180 (expressed as percentages) for all COI sequences for hoverflies recorded in Britain used as part of this study.

\section{Chapter 5}

Figure 1 Eristalis hoverfly pollen transport networks at four grassland sites CAD (top left), LLC (top right, RHC (bottom left) and TRE (bottom right). Insects collected between June 12014 and July 152014 ('early').

Figure 2 Eristalis hoverfly pollen transport networks at four grassland sites CAD (top left), LLC (top right, RHC (bottom left) and TRE (bottom right). Insects collected between July 16 and August 312014 ('late'). 
Figure 3 Proportions (\%) of pollen DNA sequences from hoverflies on four grasslands. Early - insects collected between 1 June and 15 July. Late insects collected between 16 July and 31 August.

Figure 4 The percentage categories of the most frequent pollen DNA sequences from a single plant taxon recovered from individual Eristalis hoverflies at four grassland sites in early $(\mathrm{n}=55)$ and late $(\mathrm{n}=125)$ summer 2014

\section{Chapter 6}

Figure 1 Mean $\%$ of plant taxa pollen DNA sequences retrieved from pollen loads carried by 11 hoverfly species at three grasslands in west Wales, July August 2014.

Figure 2 Pollen transport network derived from analysis of pollen carried by hoverflies at site CAD, July - August 2014. The length of the hoverfly and plant taxon bars indicates the proportion of the respective taxa in the study, and the width of the connecting ribbon represents the strength of the interaction.

Figure 3 Pollen transport network derived from analysis of pollen carried by hoverflies at site LLC, July - August 2014. The length of the hoverfly and plant taxon bars indicates the proportion of the respective taxa in the study, and the width of the connecting ribbon represents the strength of the interaction.

Figure 4 Pollen transport network derived from analysis of pollen carried by hoverflies at site TRE, July - August 2014. The length of the hoverfly and plant taxon bars indicates the proportion of the respective taxa in the study, and the width of the connecting ribbon represents the strength of the interaction. 


\section{List of Tables}

Chapter One

Table 1 Some examples of crops shown to be dependent on wild pollinators

Table 2 British Hoverfly Genera and their associated larval forms/habitats

Table 3 Examples of generalised pollination networks from a range of habitats

\section{Chapter Two}

Table 1 Hoverfly abundance, hoverfly species richness, hoverfly Shannon H diversity, Bombus abundance, Lasioglossum abundance, site plant species richness, mean number of flowering species, mean flower score, and mean Ellenberg values for four grassland communities sampled using pan traps in 2011

Table 2 Analysis of Variance explaining insect pollinator abundance and species richness.

Table 3 Parameter estimates from log-linear regression of insect pollinator abundance and species richness on mean floral unit score, in agriculturally improved and unimproved grassland

\section{Chapter Three}

Table 1 Total number of hoverflies recorded using pan traps at four grassland sites (CAD, LLC, RHC and TRE) in west Wales, UK, $2011-2014$.

Table 2 Generalised Additive Model $(\mathrm{n}=94)$ for the effect on hoverfly abundance of ordinal date ('Date'), insolation hours ('Sun') and mean daily temperature ('Tmean) at four grassland sites in west Wales, UK, plus effect of mean rainfall (' $\mathrm{Ln}($ Rain)') at all four sites combined.

Table 3 Generalised Additive Model $(\mathrm{n}=94)$ for the effect on hoverfly species richness of ordinal date ('Date'), insolation ('Sun'), mean daily temperature ('Tmean), and mean rainfall ('Ln(Rain)') at four grassland sites in west Wales, UK.

\section{Chapter 4}

Table 1 Metadata associated with each hoverfly specimen

Table 2 Taxonomic coverage of DNA barcodes obtained by sequencing for this study or publicly available. 
Table 3 Mean \% differences in K2P distance amongst British hoverfly genera represented by more than one species.

Table 4 Pairs of species of British hoverflies with a mean K2P distance of 3\% or less.

\section{Chapter 5}

Table 1 The total number of plant taxonomic groups recorded from pollen carried by Eristalis hoverflies at four sites ('CAD', 'LLC', 'RHC' and 'TRE') in west Wales during 2014, with site plant species-richness and flower unit score (see text for definition) between June 1 and July 15 (early) and July 16 and August 31 (late).

Table 2 Values of network metric $H_{2}^{\prime}$ and the species interaction specialisation metric $d$ ' for Eristalis hoverflies at four grassland sites in west Wales from June 1 - July 15 (early) and July 16 - August 31 (late) in 2014.

\section{Chapter 6}

Table 1 Values of $\mathrm{H}_{2}$ ', plant species richness, entomophilous plant species richness, 241 number of entomophilous plants in hoverfly pollen, number of pollen taxa, and values of d' for pollen loads carried by 11 species of hoverfly at three grassland sites in west Wales, July - August 2014

Table 2 Comparison of the pollen loads of five hoverfly genera using the Jaccard Similarity Index.

\section{Chapter 7}

Table 1 A list of candidate hoverfly species for monitoring as part of a wider UK 272 pollinator monitoring scheme. Adapted from Carvell et al. (2016). 


\section{List of Abbreviations}

$\begin{array}{ll}\text { BLAST } & \text { Basic Local Alignment Search Tool } \\ \text { BOLD } & \text { Barcode of Life Database } \\ \text { bp } & \text { Base pairs } \\ \text { CBOL } & \text { Consortium for the Barcode of Life } \\ \text { COI } & \text { Mitochondrial cytochrome C oxidase subunit 1 gene } \\ \text { DEFRA } & \text { Department of Environment, Food and Rural Affairs } \\ \text { DNA } & \text { Deoxyribonucleic acid } \\ \text { GAM } & \text { Generalised Additive Model } \\ \text { GLM } & \text { Generalised Linear Model } \\ \text { HRS } & \text { Hoverfly Recording Scheme } \\ \text { IPBES } & \text { Intergovernmental Platform on Biodiversity and Ecosystem Services } \\ \text { JNCC } & \text { Joint Nature Conservation Committee } \\ \text { NBDC } & \text { National Biodiversity Data Centre } \\ \text { NVC } & \text { National Vegetation Classification } \\ \text { PCR } & \text { Polymerase chain reaction } \\ \text { PVP } & \text { Poly-vinyl pyrrolidinone } \\ \text { rbcL } & \text { Large subunit of the ribulose-bisphosphate carboxylase gene } \\ \text { SDS } & \text { Sodium dodecyl sulphate } \\ \text { UKCP09 } & \text { United Kingdom Climate Projections 2009 }\end{array}$




\section{Foreword}

This thesis is presented as an introduction, five data chapters, and a final discussion. The data chapters are presented separately as papers with associated references. Some have been published or are currently in review. Where this is the case, it is indicated at the beginning of the chapter. The introduction and final discussion also have separate reference lists attached to them.

Chapter One is an introduction to the general themes of the thesis. It discusses the ecosystem service paradigm, pollination as an ecosystem service, the role of wild pollinators in agricultural landscapes, the biology of hoverflies, and how pollination networks are structured. Finally, it discusses DNA barcoding, and its potential to unlock key questions in pollination research.

Chapter Two investigates the differences in hoverfly populations between four different grassland communities with varying degrees of agricultural improvement and soil moisture content. It examines the drivers of hoverfly abundance and species-richness in these grasslands, and differences in hoverfly communities between grasslands, and compares them to two bee genera, Bombus and Lasioglossum.

Chapter Three focusses on the marshy grasslands that will be subject of the following field data chapters. Using a four year data set accumulated during this study, it examines the impact of weather conditions on hoverfly abundance and species richness, and relates these to predictions of future climate change in Britain. 
Chapter Four describes the DNA sequencing of hoverflies, using the standard barcode region COI. Using barcodes derived from hoverflies of British origin, together with publicly available sequences of British species from other countries, it assembles a library of 206 hoverfly species barcodes. It also assesses the efficacy of DNA barcodes as a method of hoverfly identification.

Chapter Five is the first of two chapters that use DNA metabarcoding to investigate hoverfly pollen transport networks. This chapter looks specifically at the genus Eristalis, and how pollen transport networks vary between four marshy grassland sites, and between early and late summer. It also describes the structure of pollen transport networks from the individual insect to whole community.

Chapter Six continues the theme of chapter five, by using DNA metabarcoding to examine the pollen loads of eleven species of hoverfly from five genera at three marshy grassland sites. It looks at network structure, and the degree of similarity between pollen loads carried by different species. It then relates them to what is known about hoverfly foraging behaviour elsewhere in their range.

Chapter Seven is a final discussion that brings common themes together and relates them to the literature described in Chapter One. It also makes recommendations for future research 
Chapter One

GENERAL INTRODUCTION: A Background to

Ecosystem Services, Pollination, Hoverflies, and potential applications of DNA Barcoding 


\section{The Ecosystem Services Concept, and Pollination as an}

\section{Ecosystem Service}

Although the concept of ecosystem services has been discussed for about 50 years, it is only since 2005 that the concept has been popularised (Juniper 2013). There are a number of different definitions of ecosystem services (Daily 1997) but, despite subsequent refinements (Mace, Norris \& Fitter 2012), the most widely used was derived from the Millennium Ecosystem Assessment (MEA 2005), which defined ecosystem services as the benefits that people obtain from ecosystems, and sets out four broad categories of service - Supporting, Provisioning, Regulating, and Cultural (figure 1).

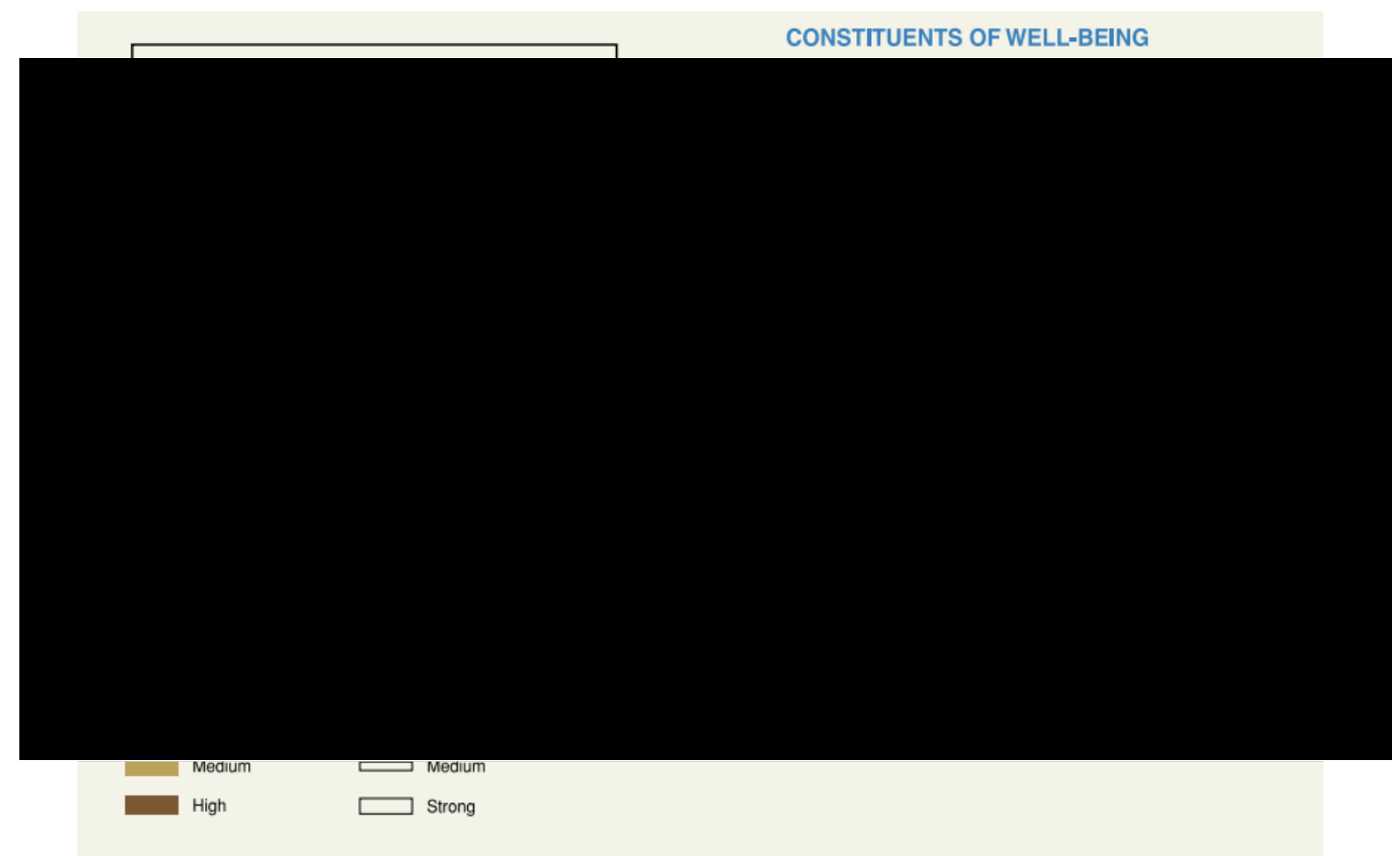

Figure 1. The linkages between ecosystem services and human well-being. From MEA (2005)

In this paradigm, pollination is primarily regarded as a regulating service, although it can also be argued that pollination is also a supporting service by facilitating plant 
reproduction (Kremen, Williams \& Aizen 2007). However, before considering pollination itself as a service, we first need to explore the background to the concept of ecosystem services itself.

\subsection{The Origins of Ecosystem Valuation}

Placing value on natural resources, particularly for hunting, has a long history (Jenkins 1990; Marvin 2006). However, it was only in the late $19^{\text {th }}$ century that the protection of nature, for whatever motive, became an accepted concept (Stamp 1969; Moss 2004). Brockington et al. (2008) described three imperatives that drove early nature conservationists, that would subsequently become a motivation to protect wider ecosystem services :

1. To preserve animals for hunting, led by the rich and powerful social classes.

2. Landscape preservation which, in Britain, has an intersection with highly anthropogenic hilly pastoral landscapes such as the Lake District.

3. The extinction crisis, to protect biodiversity.

By the $20^{\text {th }}$ century these fundamentals of nature conservation and a fledgling environmentalism were in place (Marren 2002). However, conservation remained the preserve of a small minority, with its main appeal being aesthetic, and a preoccupation with rare and exotic species (Evans 1997).

\subsection{An Emerging Environmental Awareness and Ecosystem Services}

In the early 1970s, a wider interest in the value of the environment began to emerge. Publications such as Small is Beautiful (Schumacher 1973) and Limits to Growth (Meadows et al. 1972), raised questions about how we use the world's resources. Westman (1977) drew the distinction between ecosystem 'goods' (such as forest products or minerals) and services (such as the cycling of nutrients and degradation of waste), and discussed the challenges of valuing processes in nature such as the absorption of pollutants, climate regulation, and soil formation.

The term 'environmental services' was introduced by the Study of Critical Environmental Problems (SCEP 1970). Ehrlich and Ehrlich (1981) expanded on this, explaining how 
species extinction was compromising nature's ability to provide humans with services, and used the term 'ecosystem services' for the first time. Following the United Nations Conference on Environment and Development (the 'Rio Summit') in 1992, nongovernmental organisations in Britain produced their own plan for action Biodiversity Challenge (Wynne \& Avery 1995), which acknowledged the wider value of nature, with an emphasis on the sustainable use of biological resources.

\subsection{Nature Conservation and Ecosystem Services from 2000 to the Present}

Despite over a century of effort in nature conservation, wildlife was still in serious decline. It was partly in response to this that interest in ecosystem services, and the consequent monetary valuation of nature, grew. If the neoliberal consensus in the West had no concern for the environment for its own sake, then perhaps this might be a more fruitful approach (Heal et al. 2005; Engel, Pagiola \& Wunder 2008; Kareiva \& Marvier 2011; Kareiva, Groves \& Marvier 2014)? Could environmental destruction now be viewed not as a moral issue, but as a market failure to be addressed?

Much of the initial research on this approach was undertaken by 'The Economics of Ecosystems and Diversity' a large project mainly supported by the European Commission, the United Nations Environment Programme and the German government, which attempted to provide an economics that incorporated the value of ecosystem services \& biodiversity (TEEB 2010). Recently, the Intergovernmental Platform on Biodiversity and Ecosystem Services (IPBES) has been established, which has produced its first report for policy makers on pollinators, pollination, and food production (IPBES 2016) (see section 1.4).

The challenge of introducing such an approach would be considerable in a political framework that emphasises the production of food and other materials over such issues as climate regulation and flood alleviation (Boyd \& Banzhaf 2007; Rangathan et al. 2008; Howe et al. 2014). This would pose a significant test to ecology as a science to demonstrate the evidence that would support such an approach (Mace, Norris \& Fitter 2012; Cimon-Morin, Darveau \& Poulin 2013; Hails \& Ormerod 2013). Attempts were made to quantify ecosystem services in a few, relatively small, defined areas (Chan et al. 2006; Costanza et al. 2006), to investigate the links between biodiversity and the 
provision of ecosystem services (Ricketts et al. 2016), and to assess how pollination services might be effectively valued (Breeze et al. 2016). In the United Kingdom, efforts have been made to incorporate the ecosystem service paradigm into planning decisions (Bateman et al. 2013), and to quantify the ecosystem service provided by the network of existing protected sites (Eigenbrod et al. 2009; Christie \& Raiment 2012; Eastwood et al. 2016; Coetzee 2017).

This approach of placing a value on nature can overemphasise the importance of charismatic species (McGinlay et al. 2017). It has been strongly condemned as sanctioning the destruction of nature deemed to have no worth, and undervaluing resources not readily amenable to such analysis (Nabhan 1996; Allen-Wardell et al. 1998; Boeraeve et al. 2015; Saunders \& Luck 2016). Rather, it is argued, nature should be conserved for its own sake (McCauley 2006; Vucetich, Nelson \& Bruskotter 2015), and the conservation paradigm should reject a strongly anthropocentric viewpoint (Silvertown 2015).

For those whose focus is primarily with biodiversity, the concern is whether the concentration on ecosystem services will translate into nature conservation (Holmes, Sandbrook \& Fisher 2016). A meta-analysis of 466 measures of biodiversity effects suggested that biodiversity does have an impact on ecosystem service delivery (Balvanera et al. 2006), which may have implications for the resilience of such services in the longer term at a time of environmental change (Oliver et al. 2015). Carrasco et al. (2014), and Mukherjee et al. (2014) argued that, in the case of tropical forest systems, a focus on ecosystem services fails to capture the full value of biodiversity. The value of natural habitats is not necessarily self-evident; Ghazoul (2007) cites an example from intensive almond production in California where growers demanded improved road and rail links (to allow domestic honey bee colonies to be moved more easily) over conserving natural habitat for pollinators, because the cost of setting aside land for this purpose was too high. Moreover, not all 'services' provided by ecosystems are beneficial: one example being diseases (Shackleton et al. 2016). The ensuing debate around 'ecosystem disservices' (Rasmussen et al. 2016) is likely only to confirm the misgivings of those who criticise this strongly anthropocentric view of environmental management (Holmes, Sandbrook \& Fisher 2016). 
Whilst the debate on the merits of ecosystem services tends to polarise, there are strong arguments to see the framing of nature as a series of overlapping paradigms (Ormerod 2014; Pearson 2016; Scharks \& Masuda 2016), where ecosystem services can be a useful concept, particularly when addressing audiences that may not be amenable to a traditional nature conservation message (Armsworth, Chan \& Daily 2007; Manfredo et al. 2016). Mace (2014) has argued powerfully that the history of nature conservation has been one of new paradigms being introduced even as existing ones continue to be used, and indeed that ecosystem services may itself have been overtaken by a 'people and nature' approach (see figure 2).

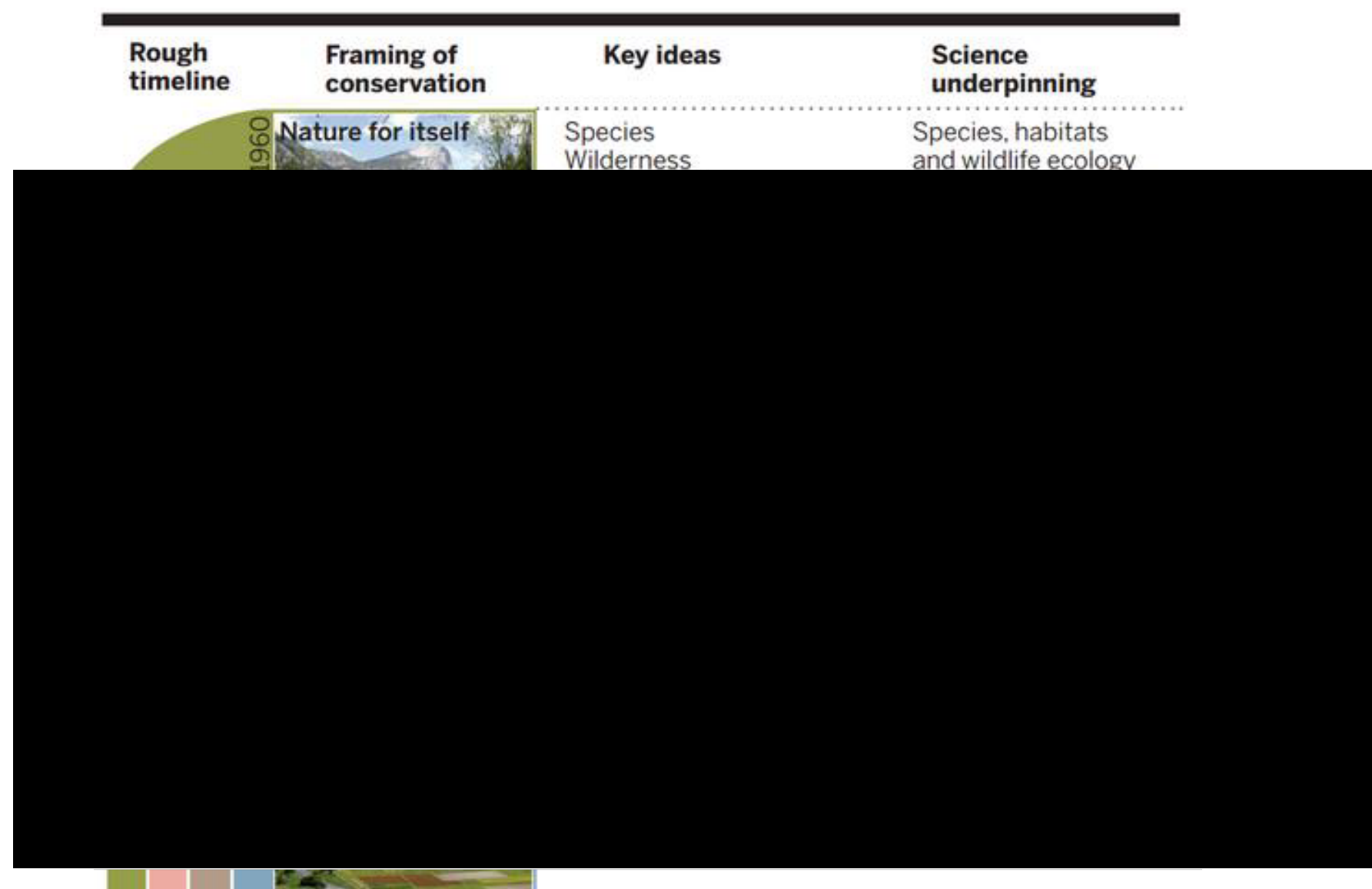

Changing views of nature and conservation. Over the past 50 years, the prevailing view of conservation has changed several times, resulting, for example, in a shift in emphasis from species to ecosystems. None of the framings has been eclipsed as new ones have emerged, resulting in multiple framings in use today.

Mace GM 2014 Whose conservation? Science 345:1558-1560

Figure 2 Changing views of nature conservation, from Mace (2014) 
Valuing ecosystems in purely economic terms may be appealing, because it provides the illusion of objectivity. However, nature conservation is, ultimately, a political choice (Chee 2004; Adams 2014).

\subsection{Pollination as an Ecosystem Service, and the Pollination 'Crisis'}

Pollination is the process in angiosperms by which male and female gametophytes (pollen and ovules) are brought together to effect reproduction (Willmer 2011). There are two main vectors of pollen transport - abiotic (wind and, more rarely, water) (Ackerman 1993; Culley, Weller \& Sakai 2002) and biotic (animal) (Ollerton, Winfree \& Tarrant 2011), with some plant species known to exploit both routes (Stelleman \& Meeuse 1976). Although pollination is generally portrayed as a process driven by insects, there are a wide range of other animals that can facilitate pollination, including mammals (Wiens et al. 1983), birds (Stiles 1975), reptiles (Traveset \& Sáez 1997), and molluscs (Sarma et al. 2007).

Pollination by insects is a key regulating ecosystem service (Nabhan \& Buchmann 1997) because successful plant reproduction underpins the wider functioning of ecosystems and an increasing proportion of much of the world's crop production (Aizen et al. 2008; Albrecht et al. 2012; Turnbull et al. 2016). A global decline in pollinator populations is now widely acknowledged (IPBES 2016), caused by a complex interaction of a number of factors, including agricultural intensification, habitat degradation, the spread of diseases and parasites, and climate change (Hegland et al. 2009; Potts et al. 2010; Goulson, Nicholls \& Botías 2015; Rundlof et al. 2015). These declines have implications for crop production, human health, and wider ecosystem function:

- Some $75 \%$ of crops rely to some extent on animal pollination (Klein et al. 2007), although they also note that $60 \%$ of food production by volume does not rely on pollination.

- The economic value of pollination has been estimated globally at $€ 153$ billion (Gallai, Salles \& Settele 2009).

- The loss of pollination, and consequent impoverishment of diet, would have considerable consequences for human health (Smith et al. 2015) 
- Over $70 \%$ of flowering plants in temperate areas rely on animal pollination in some form (Ollerton, Winfree \& Tarrant 2011), a figure that rises to $94 \%$ in tropical communities; plant diversity is, in turn, a key driver of wider ecosystem services (Isbell et al. 2011; Rzanny \& Voigt 2012; Turnbull et al. 2016).

Making the enhancement of ecosystem services an integral part of agricultural management has the potential to support pollinators, as well as a range of other species (Kovács-Hostyánszki et al. 2017). However, a purely utilitarian crop pollination argument is insufficient to justify the conservation of the majority of pollinator species, most of which play little or no role in food production (Kleijn et al. 2015).

\subsection{Climate change and Pollinators}

Climate change is predicted to have significant effects on the natural world and also the ecosystem services provided by natural systems, including pollination (Parmesan \& Yohe 2003). There are two key impacts of climate change: the phenology of both insect pollinators and plants, and changes in the range of species as populations move in response to changing temperatures (Forrest 2017). However, long-term data sets are relatively rare, making predictions regarding the effect of climate change on pollinators, and particularly on plant - pollinator interactions problematic.

The impact of climate change on pollinators has been most studied in relation to phenology - the study of seasonal phenomena. Changes in the date of first flowering in many European plants (Fitter \& Fitter 2002; Menzel et al. 2006) have been recorded, with phenological change also being noted in a range of insect pollinators. Unsurprisingly, domestic honey bees are some of the most studied, with spring first emergence dates shown to be advancing in Europe (Gordo \& Sanz 2006; Sparks et al. 2010). However, evidence can be contradictory - Langowska et al. (2017) found no significant advance in honey bee phenology in Britain, but significant increases in honey production caused by a longer overall growing, and therefore bee foraging, season. Similar advances in first appearance dates have been recorded in wild bees (Bartomeus et al. 2011; Ovaskainen et al. 2013). Such changes in in flowering times and pollinator emergence can result in reduced pollination service and lower seed production, if it results in a mismatch between a plant flowering (Kudo \& Ida 2013). Evidence for phenological change in hoverflies 
comes from two remarkable long-term studies in single English gardens (Graham-Taylor, Stubbs \& Brooke 2009; Hassall, Owen \& Gilbert 2016). Both found a clear trend of the advance of date of first appearance, notably for two species - Episyrphus balteatus and E. tenax which overwinter as adults, with many species also showing a lengthening at the end of the flight period.

Changes in ranges, with a shift to higher latitudes and altitudes, have been noted in a number of taxa (Chen et al. 2011), but information on many insect pollinator species are lacking. Most data come from butterflies, where northwards expansion of range on several British species has been recorded (Mair et al. 2012). Kerr et al. (2015) found that in bumblebees the southern edge of bumblebee ranges in North American and European species had contracted northwards, consistent with climate change, but that there had been no concomitant expansion at the northern edge of the range. Similar range contractions in endemic bees in the highly restricted South African Mediterranean biome have also been noted (Kuhlmann et al. 2012). Northwards range expansion has already been recorded in other pollinator guilds, including hoverflies, in the Netherlands (Aguirre-Gutiérrez et al. 2017). Modelling of Cheilosia hoverfly populations under climate change in the Balkans has predicted a range contraction northwards, whilst high altitude species may disappear altogether as suitable habitat contracts (Radenković et al. 2017). Similar modelling of population changes in Merodon hoverflies, also in the Balkans, has suggested that contractions in species' ranges as a response to climate change will also occur (Kaloveloni et al. 2015).

If changes in pollinator phenology and range can be expected, how will this impact on pollination networks and plant - pollinator interactions? Some authors have claimed that the multi-species nature of plant - pollinator interactions means that pollination network structure will be fairly robust to climate change, despite changes in phenology and species assemblages (Hegland et al. 2009). A study of a pollinator community comprising bees, flies and butterflies (using altitude as a proxy for climate change) found that many pollinators were comparatively flexible in their flower choice (see section 4 below for a further discussion of specialisation and generalisation in pollination networks), suggesting that functional redundancy may confer some robustness in response to changing climate (Benadi et al. 2014). Moreover, if phenological changes amongst plants and their 
pollinators occur in parallel, then the effect on pollination network structure may be minimised (Iler et al. 2013).

Conversely, mismatches between pollinators and plants have been shown to reduce seed set in some plants (see above), whilst mismatches can also have a direct effect on pollinator fitness and survival (Schenk, Krauss \& Holzschuh 2017). The response of networks to climate change will vary, depending on the degree of generalisation of the network, with greater generalisation not necessarily implying stability (Hoiss, Krauss \& Steffan-Dewenter 2015). In addition, the stability of pollination networks cannot be guaranteed based on the responses of networks to previous environmental change (Burkle, Marlin \& Knight 2013). Clearly, the response of pollination networks to climate change is highly context dependant (Forrest 2015). A thorough understanding of the structure of plant - pollinator interactions in various agricultural and natural systems is essential, in order to predict how pollination ecosystem services will react to environmental change, and to devise management strategies to mitigate any response (see section 4 , and chapters 5 and 6).

\subsection{Pollinator declines in Britain}

In Britain, insect pollinated crops account for $20 \%$ of land under cultivation, but honey bees can only supply $34 \%$ of the pollination required, suggesting a dominant role for wild pollinators (Breeze et al. 2011). Wild pollinator species diversity has declined in Britain, with both bee and hoverfly communities becoming increasingly dominated by a small number of relatively common species (Biesmeijer et al. 2006). However, the timing of pollinator declines in Britain does not mirror the post-1945 declines in other taxa (Vickery et al. 2001). Pollinator population decline began in the 1920s, in response to increasing agricultural intensification following World War I, with the rate of aculeate pollinator species extinction actually slowing in the 1960s, because most of the more sensitive species had already been lost (Ollerton et al. 2014). Long-term population trends of 213 pollinator species in Britain indicated a continued decline in distribution from 1980 to 2010 (JNCC 2016) (figure 3). However, pollinator populations appeared to have stabilised since 1998 (Carvalheiro et al. 2013), possibly in response to increasing nectar provision (Baude et al. 2016). 


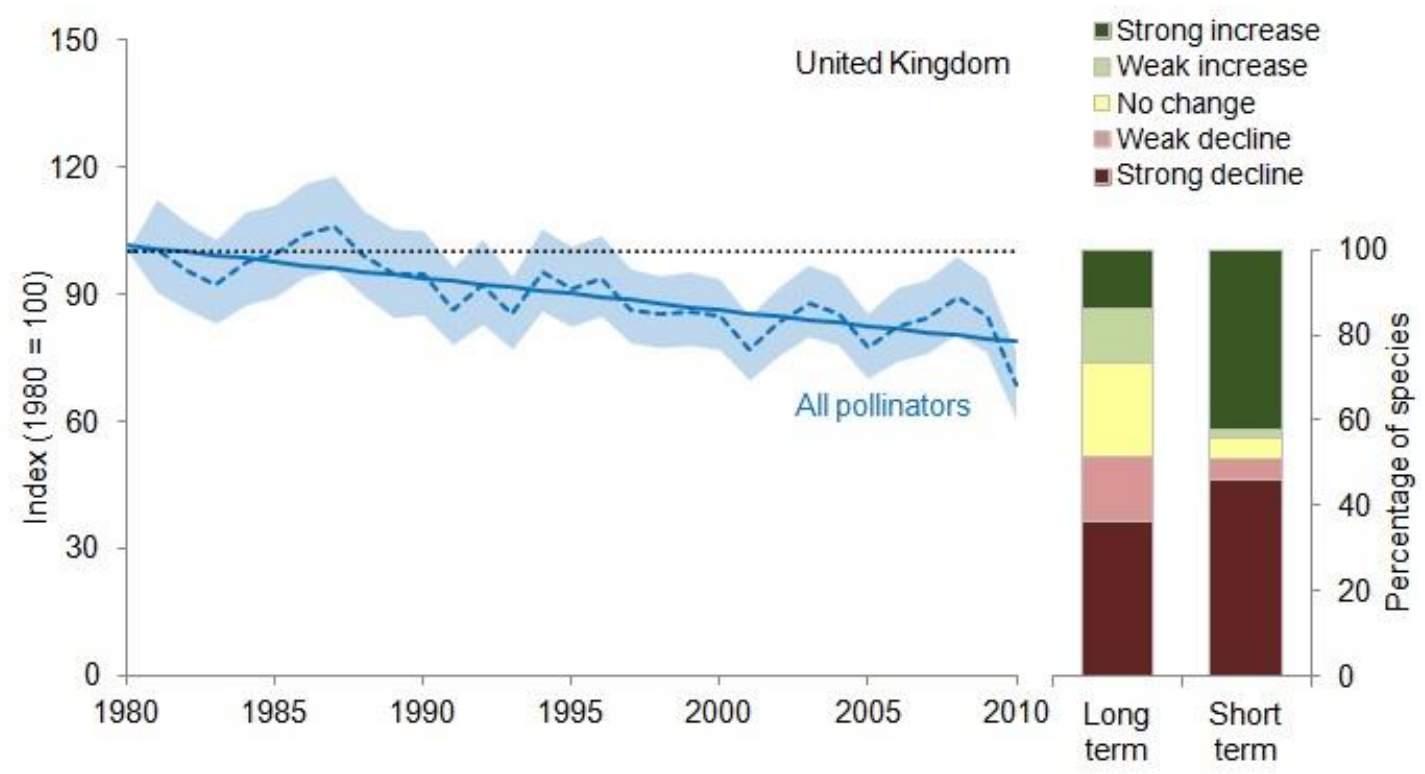

Figure 3 Change in the distribution of UK pollinators, 1980 to 2010 (JNCC 2016).

Pollinator populations can be encouraged by maintaining habitats and reducing agrochemical use (Sutherland et al. 2014; Dicks et al. 2016; Potts et al. 2016). More widely, policy initiatives to support pollinator populations in Britain and Ireland have been attempted (Welsh Government 2013; DEFRA 2014; NBDC 2015), although it is too soon to evaluate their effectiveness. Both Lye et al. (2009) and Hardman et al. (2016) found that prescriptions under agri-environment schemes had varying results with compulsory management changes more effective than a less prescriptive 'entry level' approach. Pollinator populations can operate on a scale larger than the average English farm (145ha) (McKenzie et al. 2013). Given that larger patches of habitat can support a higher species-richness of hoverflies compared to smaller areas (Ouin et al. 2006; Ockinger et al. 2012), a pattern that has been replicated in other arthropod groups (Debinski \& Holt 2000; Rosch et al. 2013; Slade et al. 2013), a more strategic landscape approach to pollinator conservation may be more effective (Meyer et al. 2017).

\section{Pollination in agricultural systems}

\subsection{The role of wild insects in pollination services}


There is considerable evidence of the importance of a diverse wild insect pollinator community to agriculture. Table 1 provides selected examples of a range of commercial crop species, grown in temperate and tropical situations, which have demonstrated a dependence on wild pollinator species. 
Table 1. Some examples of crops shown to be dependent on wild pollinators

\begin{tabular}{|c|c|c|c|}
\hline Crop Type & Location & Pollinator & Reference \\
\hline Almond Prunus dulcis & USA & Bees & (Klein et al. 2012) \\
\hline Apple Malus domestica & Hungary & Bees & (Földesi et al. 2015) \\
\hline Apple Malus domestica & USA & Bees & $\begin{array}{l}\text { (Mallinger \& Gratton } \\
\text { 2015) }\end{array}$ \\
\hline Apple Malus domestica & USA & Bees & (Blitzer et al. 2016) \\
\hline Cherry Prunus avium & Germany & Bees & $\begin{array}{l}\text { (Holzschuh, Dudenhoeffer } \\
\text { \& Tscharntke 2012) }\end{array}$ \\
\hline Field bean Vicia faba & Britain & Bees & (Bishop et al. 2016) \\
\hline $\begin{array}{c}\text { Field bean Vicia faba, } \\
\text { Strawberry Fragaria x ananassa, } \\
\text { Buckwheat Fagopyrum esculentum }\end{array}$ & $\begin{array}{l}\text { Britain, } \\
\text { Germany } \\
\text { Poland }\end{array}$ & $\begin{array}{c}\text { Bees } \\
\text { Hoverflies }\end{array}$ & (Bartomeus et al. 2014) \\
\hline Mango Mangifera indica & $\begin{array}{c}\text { Costa Rica } \\
\text { Panama }\end{array}$ & $\begin{array}{l}\text { Hoverflies } \\
\text { Other } \\
\text { Diptera }\end{array}$ & (Jiron \& Hedstrom 1985) \\
\hline Oilseed rape Brassica napus & Germany & Hoverflies & (Jauker \& Wolters 2008) \\
\hline Oilseed rape Brassica napus & Germany & $\begin{array}{c}\text { Bees } \\
\text { Hoverflies }\end{array}$ & (Jauker et al. 2012) \\
\hline Oilseed rape Brassica napus & Ireland & $\begin{array}{c}\text { Bees } \\
\text { Hoverflies }\end{array}$ & $\begin{array}{l}\text { (Stanley, Gunning \& Stout } \\
\text { 2013) }\end{array}$ \\
\hline Oilseed rape Brassica napus & Sweden & $\begin{array}{c}\text { Bees } \\
\text { Hoverflies }\end{array}$ & $\begin{array}{l}\text { (Bommarco, Marini \& } \\
\text { Vaissiere 2012) }\end{array}$ \\
\hline Pumpkin Cucurbita moschata & Indonesia & Bees & (Hoehn et al. 2008) \\
\hline Pumpkin Cucurbita moschata & USA & Bees & (Julier \& Roulston 2009) \\
\hline Raspberry Rubus idaeus & Italy & $\begin{array}{c}\text { Bees } \\
\text { Hoverflies }\end{array}$ & (Prodorutti \& Frilli 2008) \\
\hline Strawberry Fragaria $\times$ ananassa & USA & Bees & $\begin{array}{l}\text { (Connelly, Poveda \& Loeb } \\
2015)\end{array}$ \\
\hline Sunflower Helianthus annuus & USA & Bees & (Sardiñas et al. 2015) \\
\hline Sweet Pepper Capsicum annuum & USA & Hoverflies & $\begin{array}{l}\text { (Jarlan, De Oliveira \& } \\
\text { Gingras 1997) }\end{array}$ \\
\hline
\end{tabular}


Of particular note here, from an ecosystem service valuation standpoint, is that some studies were able to calculate the additional yield created by pollination by wild pollinator species. Wild pollinators have been shown to substantially increase the production, and therefore cash value, of oil seed rape Brassica napus and field beans Vicia faba (Bommarco, Marini \& Vaissiere 2012; Stanley, Gunning \& Stout 2013; Pywell et al. 2015).

A review study of 41 crop systems from around the world (Garibaldi et al. 2013) found that all showed a positive relationship between fruit set and flower visitation by wild insects, and contrasted this result with honeybees, where only $14 \%$ of studies could show a similar effect. This study also found that wild insects were more effective pollinators, enhancing fruit set by twice as much as honey bees, for the same amount of flower visitation. In other words, honey bees supplemented the impact of wild pollinators, not the reverse, as has often been supposed (Rader et al. 2009; Ollerton et al. 2012; Smith \& Saunders 2016).

\subsection{How semi-natural habitats at landscape and local scales influence wild pollinator populations}

The amount and proximity of semi-natural habitat in the surrounding landscape has been shown by several studies to increase the abundance and species-richness of wild pollinators (Ricketts et al. 2008; Jauker et al. 2013) and to increase fruit set as a consequence (Garibaldi et al. 2011). However, the responses of wild pollinator groups can vary. For example, species richness and abundance of wild bees can decline on agricultural land with distance from semi-natural habitat, but hoverfly species richness and abundance does not (Jauker et al. 2009). This emphasises a critical point: that 'wild pollinators' are not a homogenous group and may respond quite differently to changes in landscape, depending on their ecology. The rate at which flowers are visited by different wild pollinators such as social bees, solitary bees, wasps, or hoverflies can vary depending on time of day, flower height, habitat heterogeneity, management, and landscape structure (Dormann et al. 2007; Schuepp et al. 2011; Albrecht et al. 2012; Meng et al. 2012). Given such complexity, evidence-based solutions are needed (Sutherland et al. 2004; Ferraro \& Pattanayak 2006; Pullin \& Knight 2009); token efforts to promote pollinators, such as patches of non-native colourful pollinator plants or 
leguminous crops are unlikely to be effective, unless supported by sound ecological knowledge (Holzschuh et al. 2016; Samnegård et al. 2016). Understanding which insect taxa are active and capable of pollinating crops, how they behave in varying environmental conditions, and the history of landscape change, is critical to designing management to support wild pollinators (Brittain, Kremen \& Klein 2013; Garratt et al. 2014; Rosa García \& Miñarro 2014; Aguirre-Gutiérrez et al. 2015; Kovács-Hostyánszki et al. 2017).

Whilst many studies of wild pollinators in landscapes emphasise the importance of wild bees, there is an increasing number of studies that focus on the role of hoverflies in pollination (Meyer, Jauker \& Steffan-Dewenter 2009; Meyer et al. 2017). A diverse landscape with a range of habitats has been shown to contribute to hoverfly diversity in habitats as diverse as Mediterranean grasslands (Ricarte, Marcos-Garcia \& Moreno 2011) and Irish farmland (Power, Jackson \& Stout 2016). Schweiger et al. (2007) found that hoverflies were themselves not a homogenous group, and could be split into seven 'functional groups' based on existing knowledge of a range of characters including larval habitat, larval food resource, voltinism and body size. In a study across a range of sites in Europe, they found that intensive land use reduced functional group richness. This study did not investigate complementarity in pollination function, because this information was not available - see chapter 6 for an investigation of this aspect of hoverfly ecology.

Semi-natural habitat can have a 'spill-over' effect that can increase the abundance and/or species-richness of pollinators on adjacent farmland. Semi-natural habitats can potentially support pollinators at a considerable distance, with some bumblebees flying $1.5 \mathrm{~km}$ from their colonies (Osborne et al. 2008), whilst stratomyid and syrphid flies have been recorded flying 400m from flowers they had previously visited (Rader et al. 2011). Such an effect has been demonstrated in studies in farmland in Switzerland (Albrecht $e t$ al. 2007), Germany (Krewenka et al. 2011) the USA (Klein et al. 2012) and Australia (Lentini et al. 2012), whilst Liu et al. (2014) found a similar effect in China with carabid beetles, an important biological control agent in Chinese farmland.

This work on the significance of the wider landscape has led to an assessment of the amount of flower-rich habitat that is required for one particular group of pollinators, the wild bees (Dicks et al. 2015), which identified limiting resources, and proposed a series 
of management interventions. However, the authors noted that data to support a similar analysis of other pollinator taxa was lacking. These data deficiencies have helped identify future directions for pollinator research (Dicks et al. 2013).

\subsection{The value of grasslands for pollinators}

The term 'semi-natural habitat' can encompass several different community types, including woodland, scrub, fallow land, wetlands, and other habitats not under intensive agricultural production (Manhoudt \& de Snoo 2003; Grashof-Bokdam \& van Langevelde 2005). Semi-natural grasslands, in particular, are an increasingly rare habitat, especially in western Europe (Habel et al. 2013; Ridding, Redhead \& Pywell 2015; Carbutt, Henwood \& Gilfedder 2017), that have the potential to provide high quality habitat for a range of pollinators (Batary et al. 2010). Intensive agricultural grasslands also have at least the potential for restoration to a more diverse semi-improved community through appropriate management (see section 2.4) (Rodwell et al. 1992; Smith et al. 2003; Baude et al. 2016).

Given the right management regime, such grasslands could therefore have an important role in the maintenance or restoration of pollinator populations in the wider countryside (Kohler et al. 2007; Power, Kelly \& Stout 2012; Lüscher et al. 2016; Kaiser-Bunbury et al. 2017) . Increased number of flowering plant species has been shown to both increase the numbers of pollinators and, crucially for pollination as an ecosystem service, increase the temporal stability of pollinator visits (Ockinger \& Smith 2007; Ebeling et al. 2008; Ekroos, Rundlof \& Smith 2013). Wet grasslands that are similar to the 'rhos' pasture of Wales have been found to have a particularly diverse pollinator fauna (Moron et al. 2008; Carey, Williams \& Gormally 2017). The abundance and diversity of flower resource has also been shown to be a factor influencing hoverfly populations in Switzerland (Eggenschwiler et al. 2012), the Netherlands (Kleijn \& van Langevelde 2006), and in Norway (Hegland \& Boeke 2006).

Intensive grassland management can affect plant diversity, and lead to simplified and generalist insect communities (Schaffers et al. 2008; Araujo, Tscharntke \& Almeida-Neto 2015; Lázaro et al. 2015; Simons et al. 2015; Tadey 2015). Grassland management intensity has been shown to have an impact on the number of insect groups, such as 
butterflies (D'Aniello et al. 2011; Jerrentrup et al. 2014), grasshoppers (Jerrentrup et al. 2014; Sutcliffe et al. 2015), and beetles (Verdu et al. 2007), as well as bees and hoverflies (Hudewenz et al. 2012; Kormann et al. 2015). Management aimed at maximising flower resource and habitat heterogeneity can increase abundance and species richness of a range of pollinator guilds, including hoverflies (Sjodin, Bengtsson \& Ekbom 2008; Orford et al. 2016)

\subsection{Pollinators and agriculture: a summary}

In summary, there is clear evidence that diverse landscapes, with suitable resources, can provide a pollination service to adjacent farmland. In grasslands, plant diversity and agricultural management interact to influence pollinator community structure. Hoverflies form part of this wild pollinator community. What aspects of their biology make hoverflies potentially such important pollinators? What is the nature of the interaction between individual hoverflies and plant species? These are important questions if we are to fully understand the role of hoverflies in the wider pollination ecosystem service that we seek to protect (Nicolson \& Wright 2017).

\section{Hoverflies: their feeding biology and role in pollination}

\subsection{Diptera as flower visitors, and hoverflies in Britain}

Although Hymenoptera, and specifically bees, are often regarded as the most important pollinator group (see section 2 above), up 30\% of arthropod guilds regularly visit flowers, including beetles (Coleoptera), grasshoppers (Orthoptera), true bugs (Hemiptera), thrips (Thysanoptera), and butterflies and moths (Lepidoptera), as well as true flies (Diptera) (Larson, Kevan \& Inouye 2001; Inouye et al. 2015; Wardhaugh 2015). Indeed, flies can be the dominant flower visitors in some habitats, for example on islands and at high latitudes (Shrestha et al. 2016; Tiusanen et al. 2016) They are attracted by visual, olfactory and physical characters of flowers to the combination of pollen and nectar, a mixture of water and sugars, predominantly glucose, sucrose and fructose (Woodcock et al. 2014; Moyroud \& Glover 2016; Pyke 2016). Pollen is a valuable source of proteins for many insects, including hoverflies (Haslett 1989), whilst nectar is primarily a source of carbohydrate (Pinheiro et al. 2015; Abrahamczyk et al. 2017). 
There are 282 species of hoverfly (Syrphidae) in Britain (Chandler 2017), with almost all species relying on nectar for carbohydrate and pollen for fats and protein (Ball \& Morris 2013). Some species are particularly well-known for their Batesian mimicry of bees and wasps (see Eristalis tenax, a honeybee mimic, figure 4) (Golding, Edmunds \& Ennos 2005; Penney et al. 2012; Taylor, Reader \& Gilbert 2016), which can be both physical (colouration) and acoustic (Moore \& Hassall 2016). However, many species can be uniformly dark in colour (see figure 5). Figure 4 shows the key adult features that differentiate hoverflies from Hymenoptera and other Diptera: one pair of wings, the 'false wing margin' formed by the outer cross-veins running parallel to the wing edge, and (inset) the vena spuria, a reinforced hinge which cuts across the normal venation.

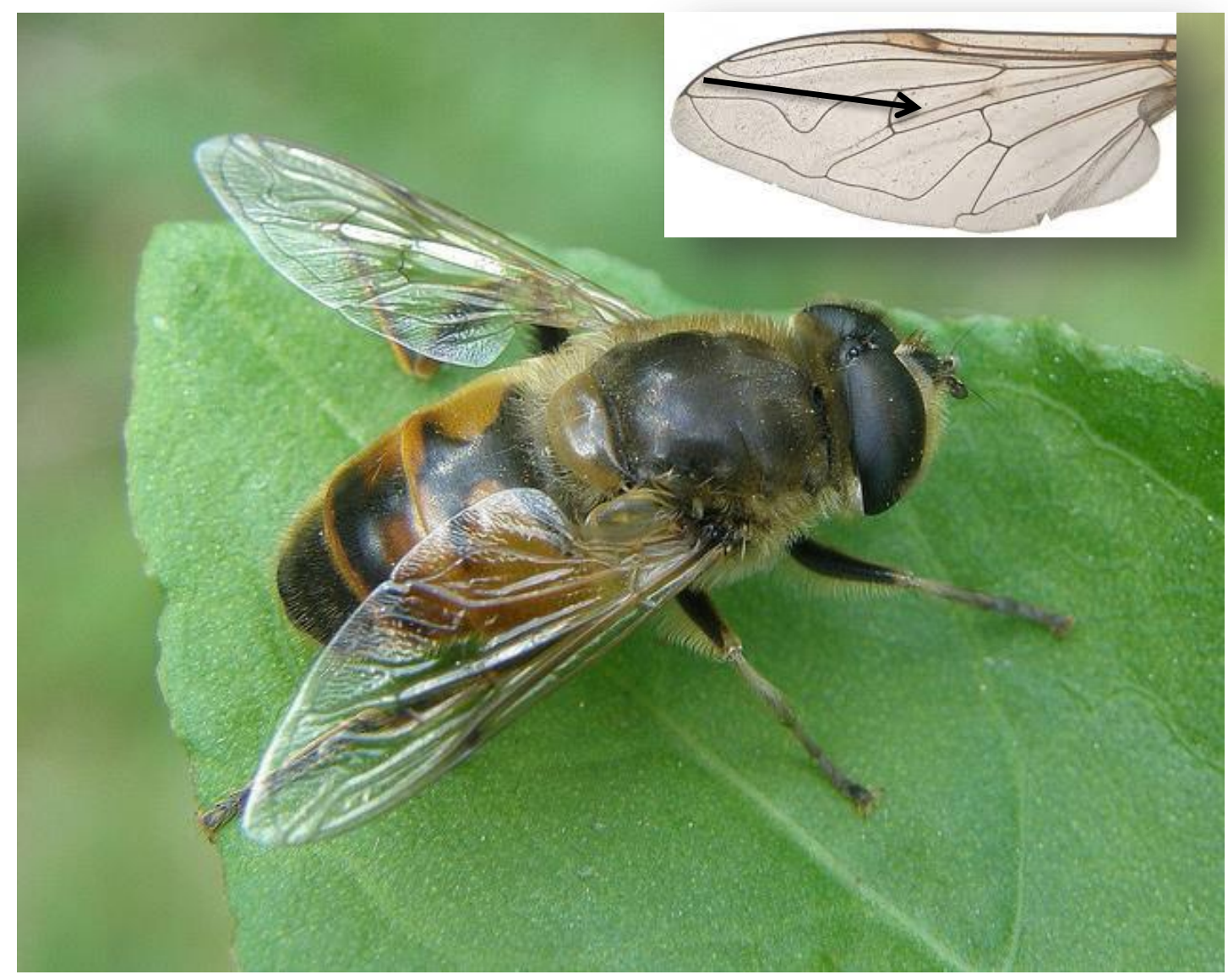

Figure 4 Eristalis tenax and (inset) wing venation showing the vena spuria (indicated by black arrow). (Image courtesy of Steven Falk)

Hoverfly species have a wide variety of larval farms and habitats (Table 2), with aphidophagous species in particular having the potential to provide a considerable pest 
control service (Ramsden et al. 2016). The larval habitats for a number of genera remain unknown, and even within well-known genera, some species' larval stages have yet to be described (e.g. Rhingia rostrata, Eristalis cryptarum ) (Ball \& Morris 2013).

Table 2 British Hoverfly Genera and their associated larval forms/habitats Data from Ball and Morris (2013)

\begin{tabular}{|c|c|}
\hline Larval form/habitat & Associated hoverfly genera \\
\hline $\begin{array}{c}\text { Aphid Feeders (various } \\
\text { habitats) }\end{array}$ & $\begin{array}{l}\text { Baccha, Melanostoma, Platycheirus, Paragus, } \\
\text { Chrysotoxum, Sphaerophoria, Eriozona, Leucozona, } \\
\text { Dasysyrphus, Didea, Scaeva, Eupeodes, Melangyna, } \\
\text { Meligramma, Meliscaeva, Episyrphus, Epistrophe, } \\
\text { Megasyrphus, Parasyrphus, Syrphus, Pipiza, Heringia, } \\
\text { Pipizella, Trichopsomyia, Triglyphus }\end{array}$ \\
\hline Moth larvae feeders & Xanthandrus \\
\hline Ant nests & Chrysotoxum, Xanthogramma, Microdon \\
\hline Dead Wood & $\begin{array}{l}\text { Callicera, Hammerschmidtia, Mallota, Blera, } \\
\text { Brachypalpoides, Caliprobola, Brachypalpus, Criorhina, } \\
\text { Pocota, Xylota }\end{array}$ \\
\hline Herbivorous & Cheilosia, Portevinea, Eumerus, Merodon, \\
\hline Fungivorous & Cheilosia, \\
\hline Sap Runs & Ferdinandea, Brachyopa, Volucella \\
\hline Dung, manure etc. & Rhingia, Syritta \\
\hline $\begin{array}{l}\text { Decaying vegetation (usually } \\
\text { semi-aquatic) }\end{array}$ & $\begin{array}{l}\text { Neoascia, Sphegina, Chysogaster, Melanogaster, } \\
\text { Orthonevra, Riponnensia, Lejogaster, Eristalis, } \\
\text { Eristalinus, Myathropa, Anasimyia, Helophilus, } \\
\text { Parhelophilus, Sericomyia, Chalcosyrphus, Tropidia }\end{array}$ \\
\hline Wasp/Bee nests & Volucella \\
\hline Unknown & Psilota, Lejops, Chamaesyrphus, Pelecocera, Doros \\
\hline
\end{tabular}


There are a number of general accounts to be found of basic hoverfly biology, taxonomy and ecology (Stubbs \& Falk 2002; Ball et al. 2011; Ball \& Morris 2013). Rotheray and Gilbert (2011) provide a comprehensive study of all aspects of hoverfly biology.

\subsection{Hoverfly feeding biology}

The feeding behaviour of a only a few hoverfly species has been investigated (Gilbert 1981; Krenn, Plant \& Szucsich 2005), but there is one particularly well-studied cosmopolitan species, Eristalis tenax (Gilbert 1983; Hansen et al. 1998; Wacht, Lunau \& Hansen 2000; Dinkel \& Lunau 2001) (figure 4). In this species, once food has been detected, the proboscis is extended until the lip of the labella comes into contact with the nectar surface, with this extension being promoted by exposure particularly to yellow light (Lunau \& Wacht 1994) (see below). The nectar is then pumped up into the proboscis. Once the nectar has fallen to a level about $1 \mathrm{~mm}$ below the surface of the labella, the proboscis is extended further and the process begins again (Gilbert 1981). When feeding, the face, proboscis, thorax and wings are frequently cleaned of accidentally transferred pollen, with much of the material ingested (Rotheray \& Gilbert 2011).

Many species, particularly small, sparsely-haired species (e.g. the genera Platycheirus and Melanostoma) ingest mostly anemophilous pollen (Holloway 1976; Ssymank \& Gilbert 1993; Hickman, Lövei \& Wratten 1995), whilst larger 'hairier' species (e.g. bee mimics in the genera Eristalis, Merodon, and Volucella) feed on pollen from nectarbearing species and can be particularly important in pollination, because pollen is readily trapped and transferred by body hairs (Stavert et al. 2016) (see also figure 5).

Observations of insects at flowers and gut analysis has shown that hoverflies can eat a wide variety of pollen (Morris 1998; Irvin et al. 1999). 


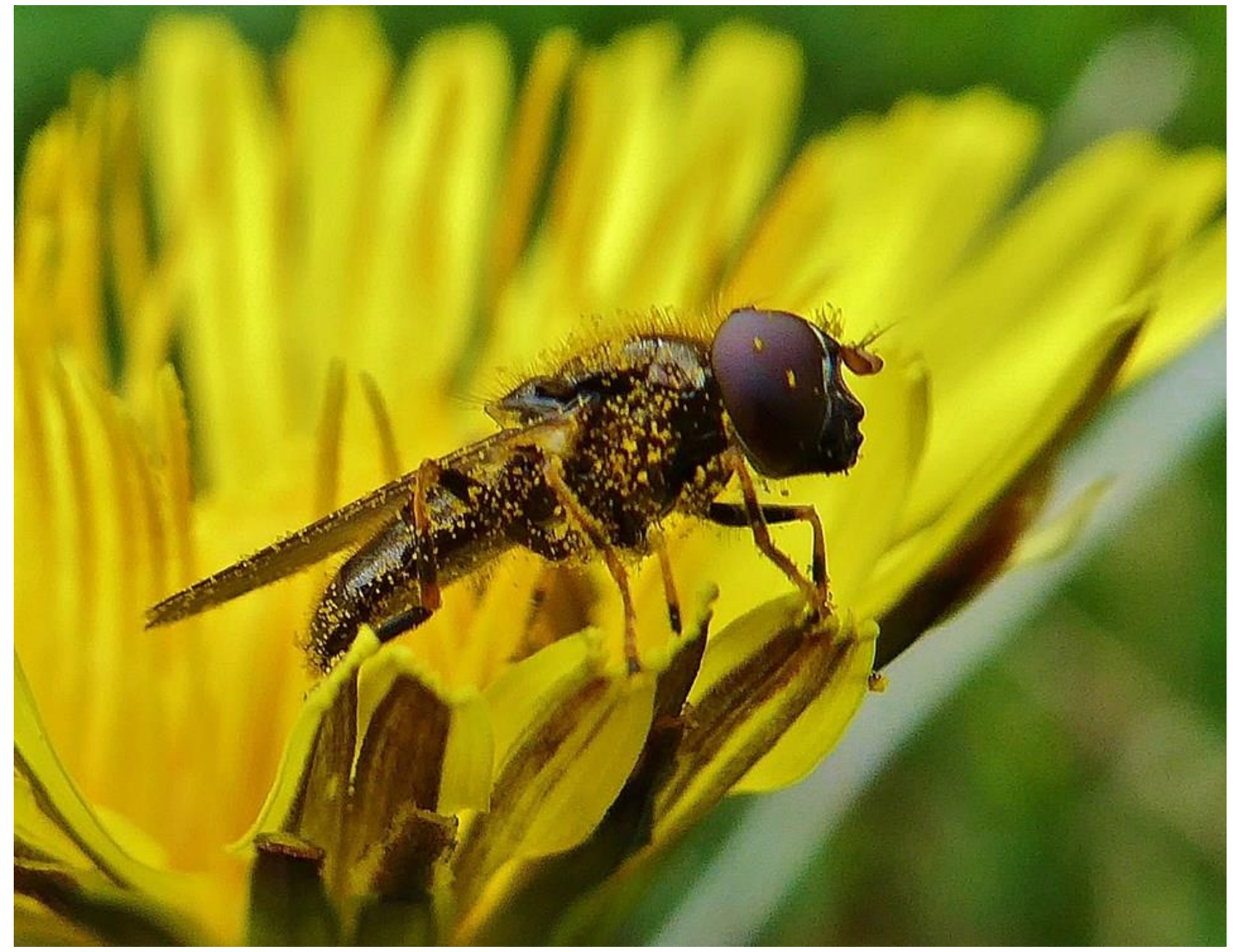

Figure 5 Cheilosia pagana. Many species in this genus are uniformly dark, quite unlike the well-known bee and wasp mimic species. Note the heavy pollen load trapped on body hairs, wings and eyes. (Image: courtesy of Kevin Bandage)

Historically, the precise method of pollen digestion was a matter of some debate (Parmenter 1958; Faegri \& van der Pijl 1979), but is now well understood (Gilbert 1981; Hickman, Lövei \& Wratten 1995). Pollen is not subject to grinding; the exines of pollen grains are frequently visible in hoverfly excreta (Golding \& Edmunds 2003). Instead, the contents of pollen grains are extruded through pores in the pollen surface, in response to osmotic pressure caused by sugars in the gut (Haslett 1983).

Hoverflies are known to be selective in their flower visitation, and can be attracted to flowers with large inflorescences and flat corollae. Some species are particularly attracted to the colour yellow (Cowgill, Wratten \& Sotherton 1993; Sutherland, Sullivan \& Poppy 1999; Branquart \& Hemptinn 2000; Nuttman \& Willmer 2008), which may relate to a feeding response initiated by specific eye photoreceptors (Lunau \& Wacht 1994). These preferences may reflect some partitioning of floral resources with other 
pollinator guilds (e.g. bees), who can access flowers with different structures (Pontin et al. 2006) In a study using artificial flowers of varying designs, Eristalis tenax (see above) has been shown to respond to 'guide lines' on petals which direct feeding towards the centre of flowers (Dinkel \& Lunau 2001) (figure 6).

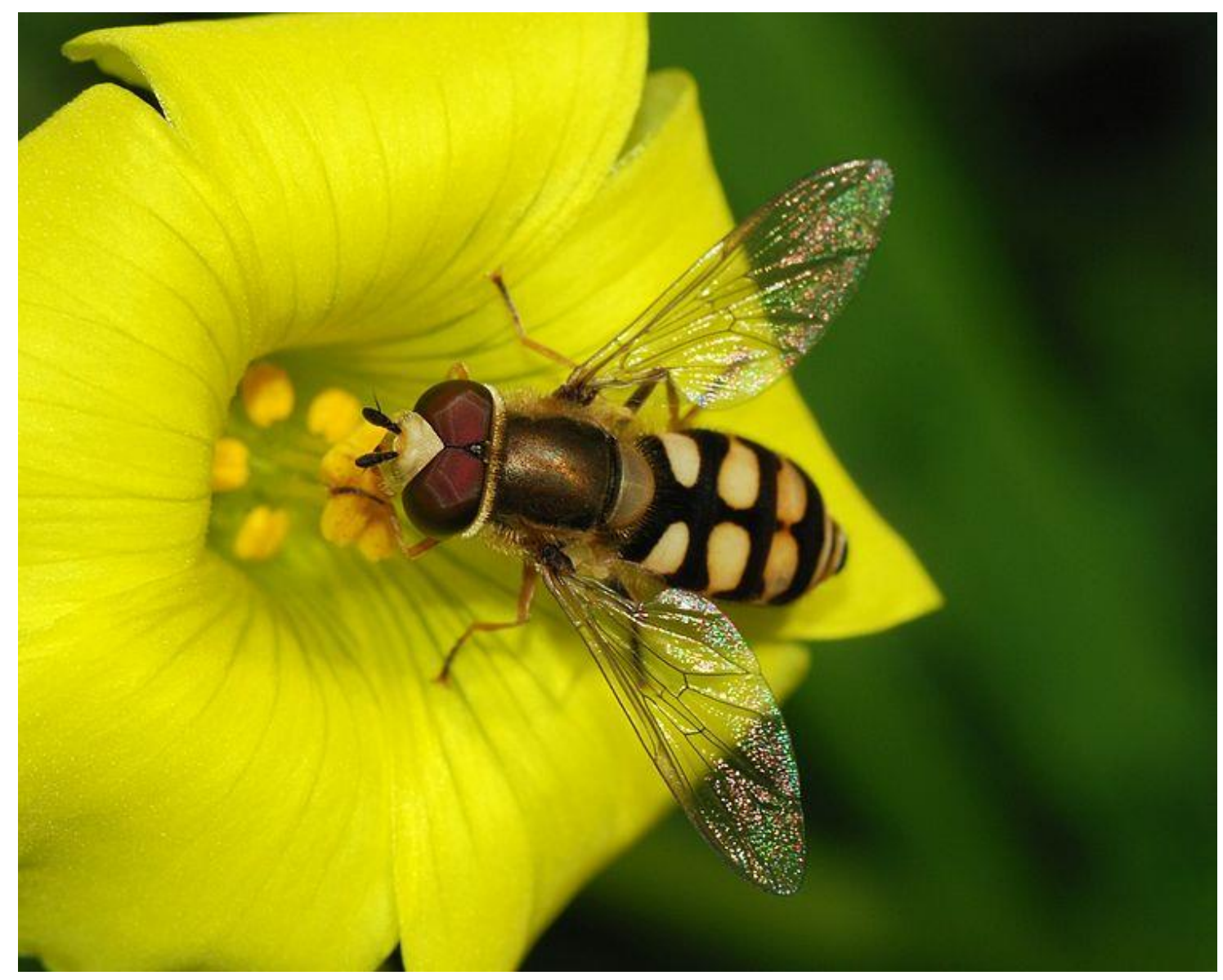

Figure 6 Hoverfly Eupeodes corollae on flower of Oxalis pes-caprae. Note the 'guidelines' on petals (Image: Wiki Commons)

Some species have also been shown to use olfactory clues to locate feeding resources. Primante \& Dotterl (2010) demonstrated that Episyrphus balteatus is attracted to the flowers of Cirsium arvense by two chemicals, methyl salicylate and 2-phenylethanol. Other physical attractants, such as structural colour, light polarisation, and even electrostatic forces have all been implicated in guiding pollinators on flowers and facilitating pollen deposition, the study of which is very much its infancy (Moyroud \& Glover 2016). 


\section{Pollination Networks}

\subsection{Hoverflies and Flower Constancy}

Flower constancy is the phenomenon whereby a pollinating animal may concentrate on one particular plant species, even whilst flowers with an equivalent, or even greater, reward nearby are ignored (Waser 1986). Observations of this behaviour date back to Aristotle, and its causes have been widely debated (Chittka, Thomson \& Waser 1999; Goulson 2000). It had been assumed that limitations in the pollinator nervous system are responsible for the behaviour and, in one oligolectic bee species, a genetic component has been identified (Praz, Müller \& Dorn 2008). Whilst these factors may have some role, it has been argued persuasively by Gruter $\&$ Ratnieks(2011) that, given the variation in flower choice within species, and the behavioural flexibility shown by pollinators in experimental situations, constancy is an adaptive foraging strategy, given the limits of a pollinator's knowledge about other resources.

A pollinating insect may benefit from concentrating on a plant species, rather than investigating other species, because that investigation process has costs (McCallum, McDougall \& Seymour 2013). Thus the insect will continue to visit a plant species of known reward, until the reward falls to a level below the cost of investigating alternatives (Goulson 1999), which has been termed the 'costly-information hypothesis' (Chittka, Thomson \& Waser 1999; Gruter \& Ratnieks 2011). Such behaviour has implications for the coexistence of plant species in communities, because it can increase reproductive isolation (Goulson 1994; Song \& Feldman 2013), which will be further discussed at the end of section 4.2. In turn, plants may evolve floral traits making them particularly attractive to groups of pollinators (Rosas-Guerrero et al. 2014; Ollerton et al. 2015), increasing the probability that any pollen transferred to a pollinator will be deposited on the stigma of a conspecific.

Using pollen microscopy, Gyan and Woodell (1987) characterised pollen loads, and inferred floral constancy, in Eristalis hoverflies in a limited study of their feeding on blackthorn Prunus spinosa, hawthorn Crataegus monogyna, dog rose Rosa canina, and bramble Rubus fruticosus. Flower constancy was also demonstrated in Episyrphus balteatus and Syrphus ribesii (Goulson \& Wright 1998) using canes to mark the foraging 
path of hoverflies as they were watched feeding. A degree of flower selection by Episyprhus balteatus was also noted by Cowgill et al. (1993).

However, these studies suffer from inevitable limitations. Fast-flying hoverflies can be difficult to follow for any length of time in the wild (Goulson \& Wright 1998). Identification of pollen using microscopy can be challenging (see introduction of chapter 5 and 6). In addition, human observers can only observe insects in places that humans themselves can access; Birtele \& Hardersen (2012) showed that hoverfly species can forage at a range of heights from ground level to woodland canopy. Thus, whilst flower constancy might be expected to occur in hoverflies, the evidence for it is limited.

\subsection{Generalisation and specialisation in plant/pollinator interactions}

The behaviour of individual insects, and any floral constancy that they may demonstrate, has led to a debate about how the behaviour of individual pollinators combine to create pollination networks at the community level. Pollination systems provide systems that are amenable to the study of species interactions; Darwin himself investigated the relationships between orchids and their pollinators (Darwin 1877). In broad terms (but see below), this is a continuum of relationships where, in the case of a generalised network, plants interact with multiple pollinators, and pollinators in turn visit multiple plants, as opposed to a system where plants have a relationship with one (or a small number) of pollinators, and vice versa (Jordano 1987; Waser et al. 1996).

It has long been recognised that pollination can provide examples of exceptional coevolution between species (Faegri \& van der Pijl 1979; Willmer 2011). In tropical regions, the relationship between plant reproductive biology and hoverfly feeding behaviour has given rise to some remarkable mutualisms (Pansarin 2008; Stokl et al. 2011). In contrast, many pollination systems, particularly in the relatively well-studied northern hemisphere, have often been described as generalised (Armbruster 2016). Memmott (1999) was one of the first to advocate that, rather than studying interactions between specific pollinator and plant species, ecologists should study pollinator networks using metrics (such as connectance) already used in studying predator/prey interactions. She advocated the collection of data to describe whole networks, and suggested that plant species that were critical to pollination networks (because their removal could cause 
significant change in wider network structure) could be termed keystone species, in the same sense as those in food webs (see below) (Traveset, Tur \& Eguiluz 2017).

If one pollinator group is particularly effective, selection should favour phenotypic traits which encourage that pollinator to the exclusion of others. It is this suite of floral characters, such as colour, shape and depth, that have been termed 'pollination syndromes' (Mitchell et al. 2009), although when the concept has been tested, differences in visitation frequency by pollinators to plants with supposed similar characters have been observed (Hegland \& Totland 2005). Ollerton et al. (2009) studied 482 plant species from six communities that they scored for classical pollination syndromes and described their most common pollinator. They found that almost no plant fell within syndrome clusters, and the most common pollinator could not be predicted by the proposed syndrome in the majority of cases.

Confusion over what is meant by the terms 'generalised' and 'specialised', and whether the term has been applied to plant or pollinator, has also been a feature of this debate. In their review of pollination systems, Ollerton et al. (2007) define three types of 'generalisation' and 'specialisation' in plants:

- Ecological generalisation or specialisation. The number of effective pollinators with which a plant interacts (the definition corresponding to that used by Waser et al. (1996) above).

- Functional generalisation or specialisation: the diversity of pollinators that service a plant at a higher taxonomic level. Examples could be 'bee pollinated' or 'fly pollinated'.

- Phenotypic generalisation or specialisation: refers to the adaptations exhibited by a flower, such as radial symmetry, special rewards, or flowering time that attract specific pollinators.

A plant may be generalist or specialist, according to definition. Ollerton et al. (op.cit.) cite the example of Daucus carota, a member of the Apiaceae that is ecologically generalised, in that a large number of flies and beetles are possible pollinators. But this plant is arguably functionally and phenotypically specialised, because its small white 
umbels of flowers and diffuse nectar rewards attracts smaller insects, whilst deterring larger pollinators such as bumblebees.

Generalised networks, with plants having multiple potential pollinators, and pollinators in turn visiting many plant species, have now been described in many habitats (Table 3). The importance of temporal variation in pollination networks should also be noted, since they can be very plastic, and specialisation can be overemphasised if only a single field season is considered (Alarcón, Waser \& Ollerton 2008; Petanidou et al. 2008; CaraDonna et al. 2017). In contrast, whilst a pollinator may be visiting multiple plants (and therefore deemed to be a 'generalist') it may be exploiting a series of plant species for specific resources, and may be better termed a serial specialist (Armbruster 2016). Moreover, there is a great deal of variation in network structure, with some specialised plants visited by generalised pollinators, whilst some specialised pollinators also visit generalised plants (Ollerton et al. 2003; Vázquez et al. 2009; de Brito et al. 2017). 
Table 3 Examples of generalised pollination networks from a range of habitats.

'Multiple Insect Taxa' indicates that the study used data from a range of pollinator species, including Hymenoptera, Diptera, Coleoptera and Lepidoptera.

\begin{tabular}{|c|c|c|c|}
\hline $\begin{array}{c}\text { Pollination Network } \\
\text { Habitat }\end{array}$ & Taxa & Location & Reference \\
\hline Alpine meadows & $\begin{array}{l}\text { Multiple Insect } \\
\text { Taxa }\end{array}$ & China & (Fang \& Huang 2012) \\
\hline Agricultural grasslands & $\begin{array}{l}\text { Multiple Insect } \\
\text { Taxa }\end{array}$ & Argentina & $\begin{array}{c}\text { (Marrero, Torretta \& } \\
\text { Medan 2014) }\end{array}$ \\
\hline Hay Meadows & $\begin{array}{l}\text { Multiple Insect } \\
\text { Taxa }\end{array}$ & England & (Forup \& Memmott 2005) \\
\hline Heathland & $\begin{array}{c}\text { Multiple Insect } \\
\text { Taxa }\end{array}$ & Belgium & $\begin{array}{l}\text { (Mahy, Sloover \& } \\
\text { Jacquemart 1998) }\end{array}$ \\
\hline Heathland & $\begin{array}{c}\text { Multiple Insect } \\
\text { Taxa }\end{array}$ & England & (Forup et al. 2008) \\
\hline Heathland & $\begin{array}{c}\text { Multiple Taxa } \\
\text { (invertebrate and } \\
\text { vertebrate) }\end{array}$ & Mauritius & $\begin{array}{c}\text { (Kaiser-Bunbury, } \\
\text { Memmott \& Müller 2009) }\end{array}$ \\
\hline Heathland & $\begin{array}{c}\text { Bumblebees } \\
\text { (Bombus) }\end{array}$ & England & $\begin{array}{c}\text { (Ballantyne, Baldock \& } \\
\text { Willmer 2015) }\end{array}$ \\
\hline Heathland & $\begin{array}{l}\text { Multiple Insect } \\
\text { Taxa }\end{array}$ & France & (Descamps et al. 2015) \\
\hline Oceanic Islands & $\begin{array}{l}\text { Multiple Insect } \\
\text { taxa }\end{array}$ & Lanzarote & $\begin{array}{c}\text { (Castro-Urgal \& Traveset } \\
\text { 2014) }\end{array}$ \\
\hline Desert & $\begin{array}{l}\text { Multiple Insect } \\
\text { taxa }\end{array}$ & Argentina & (Chacoff et al. 2012) \\
\hline Boreal Forest & $\begin{array}{l}\text { Nocturnal } \\
\text { Lepidoptera }\end{array}$ & Scotland & $\begin{array}{l}\text { (Devoto, Bailey \& } \\
\text { Memmott 2011) }\end{array}$ \\
\hline Wetland & $\begin{array}{l}\text { Multiple Insect } \\
\text { taxa }\end{array}$ & Portugal & $\begin{array}{c}\text { (Banza, Belo \& Evans } \\
\text { 2015) }\end{array}$ \\
\hline Urban & $\begin{array}{l}\text { Multiple Insect } \\
\text { taxa }\end{array}$ & Poland & $\begin{array}{c}\text { (Jedrzejewska-Szmek \& } \\
\text { Zych 2013) }\end{array}$ \\
\hline Urban & $\begin{array}{l}\text { Multiple Insect } \\
\text { Taxa }\end{array}$ & England \& Scotland & (Baldock et al. 2015) \\
\hline
\end{tabular}


However, generalised networks are not without structure. In a study of a grassland pollination network, Dicks et al.(2002) found distinct pollinator compartments - subsets of pollinators that interact with a subset of available plants, but rarely interact with plants outside this subset, one of which consisted predominantly of Syrphidae visiting the radial flowers Leucanthemum vulgare, Hypochaeris radicata and Achillea millefolium. In a subsequent study of 51 pollination networks, Olesen et al. (2007) described modularity in a similar way in networks with over 150 plant and pollinator species, but never found modularity in networks with fewer than 50 species, presumably because these communities were too small to discriminate between modules. Only a relatively few species were important structurally to the networks, giving some support to Memmott's pollination 'keystone' species concept described above.

Clearly, the compartment structure of pollination networks has implications for nature conservation. The full range of pollinators (representing all compartments) will be required to maintain comprehensive pollination service, whilst variation in plant community can support a wide suite of pollinators (Weiner et al. 2014). Corbet (2000) argued that management should focus on key species within pollination networks, rather than on rarities as such. She contrasted the efforts to safeguard the rare Bombus sylvarum, rather than Bombus hortorum, a declining (but not rare) species that is now the only long-tongued pollinator in some agricultural areas of Britain. Conversely, from a plant conservation perspective, scarce plants can often share pollinators with more common plant species (Feinsinger 1987; Sakata, Sakaguchi \& Yamasaki 2014; Seifan et al. 2014). Whilst common plant species might be expected to compete for pollinators, they can also serve to maintain a viable pollination service in the wider community, which rare plant species can then exploit (Gibson et al. 2006). Although a radical change in approach, focussing on species in key functional groups, rather than rarities, may be more successful in conserving species and corresponding ecosystem processes (Devoto $e t$ al. 2012; Dee et al. 2016; Harvey et al. 2016).

If most pollination networks are generalist, a paradox remains. Since pollination requires the transport of conspecific pollen from one plant to another, how do generalised networks deliver efficient pollination (Waser 1978)? The possibility that short-term specialisation was important in plant pollination and evolution was discussed by Ollerton 
(1996). Most recently, Brosi (2016) has suggested that generalised networks may conceal within them short-term specialisation by individual insects on the basis of a single, or short series of foraging bouts, that allows pollen to be efficiently transported between conspecific plants (figure 7).

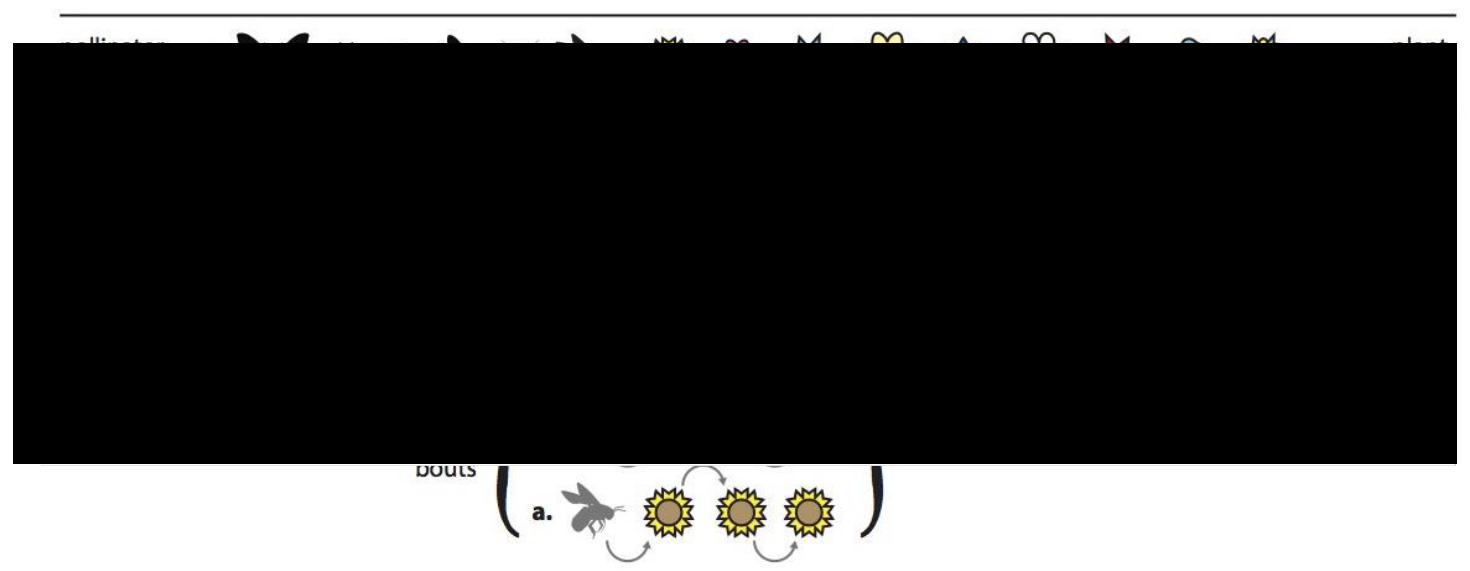

Figure 7 Pollinator generalisation and specialisation at different levels of organisation. At the community level, pollinators may appear to be generalised in their pollination behaviour, but this may resolve into a series of relatively specialised foraging bouts. From Brosi (2016)

\section{DNA Barcoding and its applications in pollination research}

\subsection{The Origins of DNA Barcoding}

DNA barcodes are short sections of genetic material, between 500 and $700 \mathrm{bp}$ long, which can be used to identify species. Hebert et al. (2003) first proposed the mitochondrial cytochrome $\mathrm{C}$ oxidase subunit 1 (CO1 or 'cox1') gene as the basis for animal identification and coined the term 'barcode' as an analogy with the Universal Product Code used to track trade items in stores. The utility of DNA barcoding stems from its use of a standard gene, leading to a universal system providing a common language for all researchers working in the field (Caterino, Cho \& Sperling 2000; Mitchell 2008). The technique quickly attracted interest as a way of overcoming the 'taxonomic impediment': the increasing need to name and identify species as part of ecology, even as taxonomic 
skills decline amongst scientists (Tautz et al. 2003; Godfray 2007). The need to integrate barcoding with existing taxonomic practice has being emphasised, placing it as an extra tool, rather than a competitor, to existing taxonomic practice (Hajibabaei et al. 2007; Pires \& Marinoni 2010).

DNA barcoding has proved to be a successful technique in revealing cryptic species, such as in the Central American butterfly Astraptes fulgerator (Hebert et al. 2004). Cryptic species of hoverfly in the genus Merodon have also been described from Greece (Radenkovic et al. 2011), using morphological approaches combined with barcoding techniques. Barcoding has also had significant applications and utility in conservation programmes (Crawford et al. 2013) and the trade in endangered species (Wong \& Hanner 2008). The recent arrival of commercially-available kits, allowing the preservation of material in the field and subsequent identification, has brought DNA barcoding technology within the realm of citizen science (www.lifescanner.net), and can even be used for school projects (Henter et al. 2016).

Designating a single locus as a suitable barcode region for plants proved to be more problematic. Such a region should be retrievable with a single primer pair, amenable to bidirectional sequencing without the need for manual editing of traces, and give the maximum amount of discrimination between species. The CBOL plant working group investigated seven potential regions, and recommended the use of a two locus combination of $r b c L$ and $m a t K$ as the universal plant barcode (CBOL Plant Working Group et al. 2009). rbcL was the best characterised gene, offering high rates of retrievability in land plants, and 'good, but not outstanding' discrimination between species. matK provided high discrimination, but with issues around the universality of primers, making recovery inconsistent. This combination has been used in the subsequent accumulation of DNA barcode libraries for land plant species (de Vere et al. 2012)

\subsection{Metabarcoding, and its use in pollination studies}

Metabarcoding uses next generation sequencing to identify species from mixed DNA samples, which can come from collections of whole organisms, or body parts, for instance from faecal samples or gut contents (Taberlet et al. 2012; Fayle et al. 2015). It does have its disadvantages; primers used in the PCR step must be universal, and if the pre-existing library of sequences is incomplete, then not all species will be identifiable. In addition, 
the absence of a species' sequence from a sample does not necessarily imply the species itself is absent, and much remains to be learned about how DNA can be transported in the environment (Roussel et al. 2015). However, the technique has been successfully used to investigate food webs (Kaartinen et al. 2010; Alex Smith et al. 2013; Garcia-Robledo et al. 2013; Vesterinen et al. 2013; Kartzinel et al. 2015), and to create species lists of arthropods for sites, allowing the comparison of communities and with community assessments (Yu et al. 2012; Moriniere et al. 2016). DNA metabarcoding has also been advocated as a method to describe complex ecological networks, such as food webs and pollination networks (Evans et al. 2016).

Techniques to identify plant species using barcoding from single pollen grains are well established (Petersen, Johansen \& Seberg 1996; Chen, Pan \& Chen 2008), even from ancient pollen samples (Parducci et al. 2005; Bennett \& Parducci 2006). Traditional pollination studies have relied either on palynological identification (Sharma 1970; O'Neill \& O'Neill 2011; Freitas et al. 2013), or on attempting to follow foraging insects (Gyan \& Woodell 1987; Beil, Horn \& Schwabe 2008). Such divergent methods of sampling can influence the resultant network structure (Gibson et al. 2011).

Metabarcoding therefore offers an insight into pollen transport by insects, by allowing the identification of mixed pollen samples without requiring specialist palynological expertise.

A number of studies have investigated the pollen loads of honey bees, since such loads can readily be retrieved from bees as they return to their hives, using pollen traps. Not only have such studies demonstrated the efficacy of the technique, but they have also revealed considerable flexibility in honey bee foraging (Galimberti et al. 2014; Danner et al. 2017; de Vere et al. 2017). Other studies have sought to compare pollen DNA metabarcoding with traditional identification of pollen through microscopy, particularly with pollen retrieved from honey ('melissopalnyology') (Schnell et al. 2010; Hawkins et al. 2015; Richardson et al. 2015). These studies have found that the two techniques provide comparable results. Melissopalnyology tends to be more reliable in providing quantitative results (because the technique involves counting individual grains), whilst DNA metabarcoding is more effective in detecting pollen species at low concentrations (Hawkins et al. 2015). 
Studies using DNA barcoding have begun to be applied to wild pollinator species, and in particular the impact of invasive non-native plant species on pollinator pollen loads. One such study investigated the diet of endemic bees from the genus Hylaeus on Hawaii (Wilson et al. 2010). Wong et al. (2015) used DNA barcoding to investigate the pollinators of Chinese knotweed Persicaria chinensis. Insect pollinators visiting the plant included many previously recorded as potential pollinators of the highly invasive Japanese knotweed P. japonica, including Eristalis hoverflies. Similar techniques have also been used to investigate the pollen transport of closely related Brassica species, which has implications for the introduction of genetically modified crops (Ronca et al. 2017).

The use of genetic techniques to investigate pollination is a field that is progressing quickly. Clare et al. (2013) described the 'promise' of genomics in the study of plantpollinator interactions, the evolution of plant traits, the co-evolution of plants and their pollinators, and as a tool to describe pollination networks. Three years later, Bell el al. (2016b) could state that, with improvements in extraction, sequencing and bioinformatics pipelines, "...now is the time for researchers..(to apply)...these methods in their research programs." The ability to sequence mixed samples using a dual indexing approach (Sickel et al. 2015) allowed Bell et al. to state that the Illumina sequencing platform was the method of choice for PCR based approaches, and discussed its application in a range of fields, including food (Hawkins et al. 2015), allergies (Kraaijeveld et al. 2015) and forensics (Bell et al. 2016a), as well as plant-pollinator interactions (Bell et al. 2017). However, there are still some caveats to the use and development of these approaches, including the tendency for species at very low concentrations to be missed in the PCR step. Advances including techniques which eliminate the PCR step, such as 'shotgun' sequencing (Creer et al. 2016), may address these deficiencies in future.

One of the most intriguing suggestions is that it may be possible to recover and sequence pollen DNA from museum specimens ('ancient DNA'). This would allow the investigation of pollination networks in 'deep time' (Vamosi et al. 2016). Such data could be invaluable in the reconstruction past of plant-pollinator networks affected by modern agriculture or climate change, as well as estimating the past prevalence of plant species now rare in modern landscapes. Such investigations have been undertaken using 
identification via light microscopy, but up to $25 \%$ of pollen can remain unidentified by such methods (Scheper et al. 2014).

\section{Key evidence gaps in pollination science and thesis questions}

With so much interest in pollination as an ecosystem service, there has been a significant effort both to systemise existing knowledge, from basic ecological concepts to the applied aspects of ecosystem services, and to identify evidence gaps (Senapathi et al. 2017). A number of authors have identified strategic gaps in the pollination science evidence base to provide focus for the research community (Steffan-Dewenter \& Westphal 2008; Mayer et al. 2011), including topics such as the interactions of pollinators and plants, taxonomy and the taxonomic impediment, drivers of pollinator loss, and pollination as an ecosystem service. Of particular note is a list of 35 priority 'knowledge needs' for the conservation of wild pollinators, compiled by Dicks et al. (2013).

Hoverflies can be significant pollinators, but are relatively understudied compared to bees. Given the relative paucity of evidence, and the potential applications of metabarcoding to address these issues, this thesis addressed the following questions and themes:

1. How does agricultural management influence hoverfly populations in grasslands?

2. How do hoverflies respond to regional weather conditions, and what does this tell us about the potential implications of climate change for the pollination service provided by hoverflies?

3. To produce a library of hoverfly COI barcode sequences, based on samples obtained from Britain together with publicly available sequences for species found in Britain.

4. What role do hoverfly species play in pollen transport in grasslands of conservation importance? How are pollen transport networks structured at the community, species, and individual level?

5. To what extent does the composition of pollen loads carried by hoverfly species vary? Are hoverfly species acting as generalist or specialist pollinators? 


\section{References}

Abrahamczyk, S., Kessler, M., Hanley, D., Karger, D.N., Muller, M.P., Knauer, A.C., Keller, F., Schwerdtfeger, M. \& Humphreys, A.M. (2017) Pollinator adaptation and the evolution of floral nectar sugar composition. Journal of Evolutionary Biology, 1, 112 - 127.

Ackerman, J.D. (1993) Pollen germination and pollen tube growth in the marine angiosperm, Zostera marina L. Aquatic Botany, 46, 189-202.

Adams, W.M. (2014) The value of valuing nature. Science, 346, 549 - 551.

Aguirre-Gutiérrez, J., Biesmeijer, J.C., van Loon, E.E., Reemer, M., WallisDeVries, M.F. \& Carvalheiro, L.G. (2015) Susceptibility of pollinators to ongoing landscape changes depends on landscape history. Diversity and Distributions, 21, 11291140.

Aguirre-Gutiérrez, J., Kissling, W.D., Biesmeijer, J.C., WallisDeVries, M.F., Reemer, M. \& Carvalheiro, L.G. (2017) Historical changes in the importance of climate and land use as determinants of Dutch pollinator distributions. Journal of Biogeography, 44, 696-707.

Aizen, M.A., Garibaldi, L.A., Cunningham, S.A. \& Klein, A.M. (2008) Long-Term Global Trends in Crop Yield and Production Reveal No Current Pollination Shortage but Increasing Pollinator Dependency. Current Biology, 18, 1572-1575.

Alarcón, R., Waser, N.M. \& Ollerton, J. (2008) Year-to-year variation in the topology of a plant-pollinator interaction network. Oikos, 117, 1796-1807.

Albrecht, M., Duelli, P., Mueller, C., Kleijn, D. \& Schmid, B. (2007) The Swiss agrienvironment scheme enhances pollinator diversity and plant reproductive success in nearby intensively managed farmland. Journal of Applied Ecology, 44, 813822. 
Albrecht, M., Schmid, B., Hautier, Y. \& Muller, C.B. (2012) Diverse pollinator communities enhance plant reproductive success. Proceedings of the Royal Society B-Biological Sciences, 279, 4845-4852.

Alex Smith, M., Fernández-Triana, J.L., Eveleigh, E., Gómez, J., Guclu, C., Hallwachs, W., Hebert, P.D.N., Hrcek, J., Huber, J.T., Janzen, D., Mason, P.G., Miller, S., Quicke, D.L.J., Rodriguez, J.J., Rougerie, R., Shaw, M.R., Várkonyi, G., Ward, D.F., Whitfield, J.B. \& Zaldívar-Riverón, A. (2013) DNA barcoding and the taxonomy of Microgastrinae wasps (Hymenoptera, Braconidae): impacts after 8 years and nearly 20000 sequences. Molecular Ecology Resources, 13, 168 176.

Allen-Wardell, G., Bernhardt, P., Bitner, R., Burquez, A., Buchmann, S., Cane, J., Cox, P.A., Dalton, V., Feinsinger, P., Ingram, M., Inouye, D., Jones, C.E., Kennedy, K., Kevan, P., Koopowitz, H., Medellin, R., Medellin-Morales, S., Nabhan, G.P., Pavlik, B., Tepedino, V., Torchio, P. \& Walker, S. (1998) The potential consequences of pollinator declines on the conservation of biodiversity and stability of food crop yields. Conservation Biology, 12, 8-17.

Araujo, W.S., Tscharntke, T. \& Almeida-Neto, M.R. (2015) Global effects of land use intensity on the impoverishment of insect herbivore assemblages. Biodiversity and Conservation, 24, 271 - 285.

Armbruster, W.S. (2016) The specialization continuum in pollination systems: diversity of concepts and implications for ecology, evolution and conservation. Functional Ecology 3188 - 100

Armsworth, P.R., Chan, K.M.A. \& Daily, G.C.E., P.R.Kremen, C.Ricketts, T.H.Sanjayan, M.A. (2007) Ecosystem-Service Science and the Way Forward for ConservationEcosystem-Service Science and the Way Forward for Conservation. Conservation Biology, 21, 1383 - 1384.

Baldock, K.C.R., Goddard, M.A., Hicks, D.M., Kunin, W.E., Mitschunas, N., Osgathorpe, L.M., Potts, S.G., Robertson, K.M., Scott, A.V., Stone, G.N., Vaughan, I.P. \& Memmott, J. (2015) Where is the UK's pollinator biodiversity? 
The importance of urban areas for flower-visiting insects. Proceedings of the Royal Society of London B: Biological Sciences, 282. DOI:

10.1098/rspb.2014.2849

Ball, S. \& Morris, R. (2013) Britain's Hoverflies; An introduction to the hoverflies of Britain. Princeton University Press.

Ball, S., Morris, R., Rotheray, G. \& Watt, K. (2011) Atlas of the Hoverflies af Great Britain (Diptera, Syrphidae). Wallingford Biological Records Centre

Ballantyne, G., Baldock, K.C.R. \& Willmer, P.G. (2015) Constructing more informative plant-pollinator networks: visitation and pollen deposition networks in a heathland plant community. Proceedings of the Royal Society of London B: Biological Sciences, 282. DOI: 10.1098/rspb.2015.1130.

Balvanera, P., Pfisterer, A.B., Buchmann, N., He, J., Nakashizuka, T., Raffaelli, D. \& Schmid, B. (2006) Quantifying the evidence for biodiversity effects on ecosystem functioning and services. Ecology Letters, 9, 1146 - 1156.

Banza, P., Belo, A.D.F. \& Evans, D.M. (2015) The structure and robustness of nocturnal Lepidopteran pollen-transfer networks in a Biodiversity Hotspot. Insect Conservation and Diversity, 8, 538-546.

Bartomeus, I., Ascher, J.S., Wagner, D., Danforth, B.N., Colla, S., Kornbluth, S. \& Winfree, R. (2011) Climate-associated phenological advances in bee pollinators and bee-pollinated plants. Proceedings of the National Academy of Sciences, 108, 20645-20649.

Bartomeus, I., Potts, S.G., Steffan-Dewenter, I., Vaissière, B.E., Woyciechowski, M., Krewenka, K.M., Tscheulin, T., Roberts, S.P.M., Szentgyörgyi, H., Westphal, C. \& Bommarco, R. (2014) Contribution of insect pollinators to crop yield and quality varies with agricultural intensification. PeerJ, 2:e328 https://doi.org/10.7717/peerj.328. 
Batary, P., Baldi, A., Saropataki, M., Kohler, F., Verhulst, J., Knop, E., Herzog, F. \& Kleijn, D. (2010) Effect of conservation management on bees and insectpollinated grassland plant communities in three European countries. Agriculture Ecosystems \&amp; Environment, 136, 35-39.

Bateman, I., Harwood, A., Mace, G., Watson, R., Abson, D., Andrews, B., Binner, A., Crowe, A., Day, B., Dugdale, S., Fezzi, C., Foden, J., Hadley, D., Haines-Young, R., Hulme, M., Kontoleon, A., Lovett, A., Munday, P., Pascual, U., Paterson, J., Perino, G., Sen, A., Siriwardena, G., van Soest, D. \& Termansen, M. (2013) Bringing Ecosystem Services into Economic Decision-Making: Land Use in the United Kingdom. Science, 341, 45-50.

Baude, M., Kunin, W.E., Boatman, N.D., Conyers, S., Davies, N., Gillespie, M.A.K., Morton, R.D., Smart, S.M. \& Memmott, J. (2016) Historical nectar assessment reveals the fall and rise of floral resources in Britain. Nature, 530, 85-88.

Beil, M., Horn, H. \& Schwabe, A. (2008) Analysis of pollen loads in a wild bee community (Hymenoptera: Apidae) - a method for elucidating habitat use and foraging distances. Apidologie, 39, 456 - 457.

Bell, K.L., Burgess, K.S., Okamoto, K.C., Aranda, R. \& Brosi, B.J. (2016a) Review and future prospects for DNA barcoding methods in forensic palynology. Forensic Science International: Genetics, 21, 110-116.

Bell, K.L., de Vere, N., Keller, A., Richardson, R.T., Gous, A., Burgess, K.S. \& Brosi, B.J. (2016b) Pollen DNA barcoding: current applications and future prospects. Genome, 59, 1-12.

Bell, K.L., Fowler, J., Burgess, K.S., Dobbs, E.K., Gruenewald, D., Lawley, B., Morozumi, C. \& Brosi, B.J. (2017) Applying pollen DNA metabarcoding to the study of plant-pollinator interactions. Applications in Plant Sciences, 5(6):1600124. 2017 https://doi.org/10.3732/apps.1600124 
Benadi, G., Hovestadt, T., Poethke, H.J. \& Bluthgen, N. (2014) Specialization and phenological synchrony of plant-pollinator interactions along an altitudinal gradient. Journal of Animal Ecology, 83, 639-650.

Bennett, K. \& Parducci, L. (2006) DNA from pollen: principles and potential. Holocene, 16, 1031-1034.

Biesmeijer, J.C., Roberts, S.P.M., Reemer, M., Ohlemuller, R., Edwards, M., Peeters, T., Schaffers, A.P., Potts, S.G., Kleukers, R., Thomas, C.D., Settele, J. \& Kunin, W.E. (2006) Parallel declines in pollinators and insect-pollinated plants in Britain and the Netherlands. Science, 313, 351-354.

Birtele, D. \& Hardersen, S. (2012) Analysis of vertical stratification of Syrphidae (Diptera) in an oak-hornbeam forest in northern Italy. Ecological Research, 27, $755-763$.

Bishop, J., Jones, H.E., Lukac, M. \& Potts, S.G. (2016) Insect pollination reduces yield loss following heat stress in faba bean (Vicia faba L.). Agriculture, Ecosystems \& Environment, 220, 89-96.

Blitzer, E.J., Gibbs, J., Park, M.G. \& Danforth, B.N. (2016) Pollination services for apple are dependent on diverse wild bee communities. Agriculture, Ecosystems \& Environment, 221, 1-7.

Boeraeve, F., Dendoncker, N., Jacobs, S., Gómez-Baggethun, E. \& Dufrêne, M. (2015) How (not) to perform ecosystem service valuations: pricing gorillas in the mist. Biodiversity and Conservation, 1, 187 - 197.

Bommarco, R., Marini, L. \& Vaissiere, B.E. (2012) Insect pollination enhances seed yield, quality, and market value in oilseed rape. Oecologia, 169, 1025-1032.

Boyd, J. \& Banzhaf, S. (2007) What are ecosystem services? The need for standardized environmental accounting units. Ecological Economics, 63, 616 - 626.

Branquart, E. \& Hemptinn, J. (2000) Selectivity in the exploitation of floral resources by hoverflies (Diptera: Syrphinae). Ecography, 23, 732 - 742. 
Breeze, T., Bailey, A., Balcombe, K. \& Potts, S. (2011) Pollination services in the UK: How important are honeybees? Agriculture Ecosystems \& Environment, 142, 137 143.

Breeze, T.D., Gallai, N., Garibaldi, L.A. \& Li, X.S. (2016) Economic Measures of Pollination Services: Shortcomings and Future Directions. Trends in Ecology and Evolution. 31, 927 - 939

Brittain, C., Kremen, C. \& Klein, A.-M. (2013) Biodiversity buffers pollination from changes in environmental conditions. Global Change Biology, 19, 540-547.

Brockington, D., Duffy, R. \& Igoe, J. (2008) Conservation, Capitalism and the Future of Protected Areas. Earthscan, London.

Brosi, B.J. (2016) Pollinator specialization: from the individual to the community. New Phytologist, 4, 1190 - 1194.

Burkle, L.A., Marlin, J.C. \& Knight, T.M. (2013) Plant-Pollinator Interactions over 120 Years: Loss of Species, Co-Occurrence, and Function. Science, 339, 1611.

CaraDonna, P.J., Petry, W.K., Brennan, R.M., Cunningham, J.L., Bronstein, J.L., Waser, N.M. \& Sanders, N.J. (2017) Interaction rewiring and the rapid turnover of plantpollinator networks. Ecology Letters, 20: 385-394. doi:10.1111/ele.12740

Carbutt, C., Henwood, W.D. \& Gilfedder, L.A. (2017) Global plight of native temperate grasslands: going, going, gone? Biodiversity and Conservation. https://doi.org/10.1007/s10531-017-1398-5

Carey, J.G.J., Williams, C.D. \& Gormally, M.J. (2017) Spatiotemporal variation of Diptera changes how we evaluate High Nature Value (HNV) wet grasslands. Biodiversity and Conservation, 26: 1541. https://doi.org/10.1007/s10531-017$1314-\mathrm{z}$

Carrasco, L.R., Nghiem, T.P.L., Sunderland, T. \& Koh, L.P. (2014) Economic valuation of ecosystem services fails to capture biodiversity value of tropical forests. Biological Conservation, 178, 163 - 170. 
Carvalheiro, L.G., Kunin, W.E., Keil, P., Aguirre-Gutiérrez, J., Ellis, W.N., Fox, R., Groom, Q., Hennekens, S., Van Landuyt, W., Maes, D., Van de Meutter, F., Michez, D., Rasmont, P., Ode, B., Potts, S.G., Reemer, M., Roberts, S.P.M., Schaminée, J., WallisDeVries, M.F. \& Biesmeijer, J.C. (2013) Species richness declines and biotic homogenisation have slowed down for NW-European pollinators and plants. Ecology Letters, 16, 870-878.

Castro-Urgal, R. \& Traveset, A. (2014) Differences in flower visitation networks between an oceanic and a continental island. Botanical Journal of the Linnean Society, 174, $478-488$.

Caterino, M.S., Cho, S. \& Sperling, F.A.H. (2000) The current state of insect molecular systematics: A thriving Tower of Babel. Annual Review of Entomology, 45, 1-54.

CBOL Plant Working Group, Hollingsworth, P.M., Forrest, L.L., Spouge, J.L., Hajibabaei, M., Ratnasingham, S., van der Bank, M., Chase, M.W., Cowan, R.S., Erickson, D.L., Fazekas, A.J., Graham, S.W., James, K.E., Kim, K.-J., Kress, W.J., Schneider, H., van AlphenStahl, J., Barrett, S.C.H., van den Berg, C., Bogarin, D., Burgess, K.S., Cameron, K.M., Carine, M., Chacón, J., Clark, A., Clarkson, J.J., Conrad, F., Devey, D.S., Ford, C.S., Hedderson, T.A.J., Hollingsworth, M.L., Husband, B.C., Kelly, L.J., Kesanakurti, P.R., Kim, J.S., Kim, Y.-D., Lahaye, R., Lee, H.-L., Long, D.G., Madriñán, S., Maurin, O., Meusnier, I., Newmaster, S.G., Park, C.-W., Percy, D.M., Petersen, G., Richardson, J.E., Salazar, G.A., Savolainen, V., Seberg, O., Wilkinson, M.J., Yi, D.-K. \& Little, D.P. (2009) A DNA barcode for land plants. Proceedings of the National Academy of Sciences, 106, 12794-12797.

Chacoff, N.P., Vázquez, D.P., Lomáscolo, S.B., Stevani, E.L., Dorado, J. \& Padrón, B. (2012) Evaluating sampling completeness in a desert plant-pollinator network. Journal of Animal Ecology, 81, 190-200.

Chan, K.M.A., Shaw, M.R., Cameron, D.R., Underwood, E.C. \& Daily, G.C. (2006) Conservation planning for ecosystem services. PLoS Biology, 4. (11): e379. https://doi.org/10.1371/journal.pbio.0040379 
Chandler, P., J. (2017) An Update of the 1998 Checklist of Diptera of the British Isles [updated 16 January 2017].

http://www.dipteristsforum.org.uk/documents/BRITISH_ISLES_CHECKLIST.pd f.

Chee, Y.E. (2004) A global perspective on the valuation of ecosystem services.

Biological Conservation, 120, 549 - 565.

Chen, I.C., Hill, J.K., Ohlemüller, R., Roy, D.B. \& Thomas, C.D. (2011) Rapid Range Shifts of Species Associated with High Levels of Climate Warming. Science, 333, 1024.

Chen, P.H., Pan, Y.B. \& Chen, R.K. (2008) High-throughput procedure for single pollen grain collection and polymerase chain. Journal of Integrative Plant Biology, 50, 375-383.

Chittka, L., Thomson, J.D. \& Waser, N.M. (1999) Flower Constancy, Insect Psychology, and Plant Evolution. Naturwissenschaften, 86, 361 - 377.

Christie, M. \& Raiment, N. (2012) An economic assessment of the ecosystem service benefits derived from the SSSI biodiversity conservation policy in England and Wales. Ecosystem Services, 1, 70 - 64.

Cimon-Morin, J., Darveau, M. \& Poulin, M. (2013) Fostering synergies between ecosystem services and biodiversity in conservation planning: A review. Biological Conservation, 166, 144 - 154.

Clare, E.L., Schiestl, F.P., Leitch, A.R. \& Chittka, L. (2013) The promise of genomics in the study of plant-pollinator interactions. Genome Biology, 14:207 https://doi.org/10.1186/gb-2013-14-6-207

Coetzee, B.W.T. (2017) Evaluating the ecological performance of protected areas. Biodiversity and Conservation, 26, 231-236. 
Connelly, H., Poveda, K. \& Loeb, G. (2015) Landscape simplification decreases wild bee pollination services to strawberry. Agriculture, Ecosystems \& Environment, 211, $51-56$.

Corbet, S.A. (2000) Conserving compartments in pollination webs. Conservation Biology, 14, 1229-1231.

Costanza, R., Wilson, M.A., Troy, A., Voinov, A., Liu, S. \& D'Agostino (2006) The value of New Jersey's ecosystem services and natural capital. New Jersey Department of Environmental Protection.

Cowgill, S.E., Wratten, S.D. \& Sotherton, N.W. (1993) The selective use of floral resources by the hoverfly Episyrphus balteatus (Diptera, Syrphidae) on farmland. Annals of Applied Biology, 122, 223-231.

Crawford, A.J., Cruz, C., Griffith, E., Ross, H., Ibáñez, R., Lips, K.R., Driskell, A.C., Bermingham, E. \& Crump, P. (2013) DNA barcoding applied to ex situ tropical amphibian conservation programme reveals cryptic diversity in captive populations. Molecular Ecology Resources, 13, 1005 - 1018.

Creer, S., Deiner, K., Frey, S., Porazinska, D., Taberlet, P., Thomas, W.K., Potter, C. \& Bik, H.M. (2016) The ecologist's field guide to sequence-based identification of biodiversity. Methods in Ecology and Evolution, 7, 1008 - 1018.

Culley, T.M., Weller, S.G. \& Sakai, A.K. (2002) The evolution of wind pollination in angiosperms. Trends in Ecology and Evolution, 17, 361-369.

D'Aniello, B., Stanislao, I., Bonelli, S. \& Balletto, E. (2011) Haying and grazing effects on the butterfly communities of two Mediterranean-area grasslands. Biodiversity and Conservation, 20, 1731-1744.

Daily, G.C. (1997) Nature's Services: Societal Dependence on Natural Ecosystems. Island Press, Washington DC. 
Danner, N., Keller, A., Hartel, S. \& Steffan-Dewenter, I. (2017) Honey bee foraging ecology: Season but not landscape diversity shapes the amount and diversity of collected pollen. PLoS One, 12, e0183716.

Darwin, C.R. (1877) The Various Contrivances By Which Orchids Are Fertilised By Insects, 2nd Ed. edn. John Murray, Albemarle Street, London.

de Brito, V.L.G., Rech, A.R., Ollerton, J. \& Sazima, M. (2017) Nectar production, reproductive success and the evolution of generalised pollination within a specialised pollen-rewarding plant family: a case study using Miconia theizans. Plant Systematics and Evolution, 303, 709-718.

de Vere, N., Jones, L., Gilmore, T., Moscrop, J., Lowe, A., Smith, D., Hegarty, M., Creer, S. \& Ford, C. (2017) Using DNA metabarcoding to investigate honey bee foraging reveals limited flower use despite high floral availability. Scientific Reports, 16;7:42838. doi: 10.1038/srep42838.

de Vere, N., Rich, T.C.G., Ford, C.R., Trinder, S.A., Long, C., Moore, C.W., Satterthwaite, D., Davies, H., Allainguillaume, J., Ronca, S., Tatarinova, T., Garbett, H., Walker, K. \& Wilkinson, M.J. (2012) DNA Barcoding the Native Flowering Plants and Conifers of Wales. Plos One, 7(6): e37945. https://doi.org/10.1371/journal.pone.0037945

Debinski, D.M. \& Holt, R.D. (2000) A survey and overview of habitat fragmentation experiments. Conservation Biology, 14, 342-355.

Dee, L.E., Allesina, S., Bonn, A., Eklöf, A., Gaines, S.D., Hines, J., Jacob, U., McDonald-Madden, E., Possingham, H., Schröter, M. \& Thompson, R.M. (2016) Operationalizing Network Theory for Ecosystem Service Assessments. Trends in Ecology and Evolution. 32: 118 - 130

DEFRA (2014) A consultation on the National Pollinator Strategy for bees and other pollinators in England. DEFRA, Bristol. 
Descamps, C., Moquet, L., Migon, M. \& Jacquemart, A.L. (2015) Diversity of the Insect Visitors on Calluna vulgaris (Ericaceae) in Southern France Heathlands. Journal of Insect Science, 15, 130, https://doi.org/10.1093/jisesa/iev116

Devoto, M., Bailey, S., Craze, P. \& Memmott, J. (2012) Understanding and planning ecological restoration of plant-pollinator networks. Ecology Letters, 15, 319-328.

Devoto, M., Bailey, S. \& Memmott, J. (2011) The 'night shift': Nocturnal pollen-transport networks in a boreal pine forest. Ecological Entomology, 36, 25-35.

Dicks, L.V., Abrahams, A., Atkinson, J., Biesmeijer, J., Bourn, N., Brown, C., Brown, M.J.F., Carvell, C., Connolly, C., Cresswell, J.E., Croft, P., Darvill, B., De Zylva, P., Effingham, P., Fountain, M., Goggin, A., Harding, D., Harding, A., Hartfield, C., Heard, M.E., Heathcote, R., Heaver, D., Holland, J., Howe, M., Hughes, B., Huxley, Y., Kunin, W.E., Little, J., Mason, C., Memmott, J., Osborne, J., Pankhurst, T., Paxton, R.J., Pocock, M.J.O., Potts, S.G., Power, E.F., Raine, N.E., Ranelagh, E., Roberts, S., Saunders, R., Smith, K., Smith, R.M., Sutton, P., Tilley, L.A.N., Tinsley, A., Tonhasca, A., Vanbergen, A.J., Webster, S., Wilson, A. \& Sutherland, W.J. (2013) Identifying key knowledge needs for evidence-based conservation of wild insect pollinators: a collaborative cross-sectoral exercise Insect Conservation and Diversity, 6, 435 - 446.

Dicks, L.V., Baude, M., Roberts, S.P.M., Phillips, J., Green, M. \& Carvell, C. (2015) How much flower-rich habitat is enough for wild pollinators? Answering a key policy question with incomplete knowledge. Ecological Entomology, 40, 22-35.

Dicks, L.V., Corbet, S.A. \& Pywell, R.F. (2002) Compartmentalization in plant-insect flower visitor webs. Journal of Animal Ecology, 71, 32-43.

Dicks, L.V., Viana, B., Bommarco, R., Brosi, B., Arizmendi, M.d.C., Cunningham, S.A., Galetto, L., Hill, R., Lopes, A.V., Pires, C., Taki, H. \& Potts, S.G. (2016) Ten policies for pollinators. Science, $\mathbf{3 5 4}, 975$.

Dinkel, T. \& Lunau, K. (2001) How drone flies (Eristalis tenax L., syrphidae, diptera) use floral guides to locate food sources. Journal of Insect Physiology, 47, 1111-1118. 
Dormann, C.F., Schweiger, O., Augenstein, I., Bailey, D., Billeter, R., de Blust, G., DeFilippi, R., Frenzel, M., Hendrickx, F., Herzog, F., Klotz, S., Liira, J., Maelfait, J.P., Schmidt, T., Speelmans, M., van Wingerden, W. \& Zobel, M. (2007) Effects of landscape structure and land-use intensity on similarity of plant and animal communities. Global Ecology and Biogeography, 16, 774-787.

Eastwood, A., Brooker, R., Irvine, R.J., Artz, R.R.E., Norton, L.R., Bullock, J.M., Ross, L., Fielding, D., Ramsay, S., Roberts, J., Anderson, W., Dugan, D., Cooksley, S. \& Pakeman, R.J. (2016) Does nature conservation enhance ecosystem services delivery? Ecosystem Services, 17, 152-162.

Ebeling, A., Klein, A.M., Schumacher, J., Weisser, W.W. \& Tscharntke, T. (2008) How does plant richness affect pollinator richness and temporal stability of flower visits? Oikos, 117, 1808-1815.

Eggenschwiler, L., Senn, M., Ferrari, A., Egli, A. \& Jacot, K. (2012) Attractiveness of extensive meadows for aphid predators. Agrarforschung Schweiz, 3, 96-103.

Ehrlich, P. \& Ehrlich, A. (1981) Extinction: The Causes and Consequences of the Disappearance of Species. Random House.

Eigenbrod, F., Anderson, B.J., Armsworth, P.R., Heinemeyer, A., Jackson, S.F., Parnell, M., Thomas, C.D. \& Gaston, K.J. (2009) Ecosystem service benefits of contrasting conservation strategies in a human-dominated region. Proceedings of the Royal Society of London B: Biological Sciences, 276, 2903-2911.

Ekroos, J., Rundlof, M. \& Smith, H.G. (2013) Trait-dependent responses of flowervisiting insects to distance to semi-natural grasslands and landscape heterogeneity. Landscape Ecology, 28, 1283-1292.

Engel, S., Pagiola, S. \& Wunder, S. (2008) Designing payments for environmental services in theory and practice. An overview of the issues. Ecological Economics, 65, $663-674$. 
Evans, D. (1997) A History of Nature Conservation in Britain, 2nd edn. Routledge, London.

Evans, D.M., Kitson, J.J.N., Lunt, D.H., Straw, N.A. \& Pocock, M.J.O. (2016) Merging DNA metabarcoding and ecological network analysis to understand and build resilient terrestrial ecosystems. Functional Ecology, 30: 1904-1916. doi:10.1111/1365-2435.12659

Faegri, K. \& van der Pijl, L. (1979) The Principles of Pollination Ecology, 3rd edn. Pergamon Press, Oxford, England.

Fang, Q. \& Huang, S.Q. (2012) Relative stability of core groups in pollination networks in a biodiversity hotspot over four years. PLoS ONE, 7. (3): e32663. https://doi.org/10.1371/journal.pone.0032663

Fayle, T.M., Scholtz, O., Dumbrell, A.J., Russell, S., Segar, S.T. \& Eggleton, P. (2015) Detection of Mitochondrial COII DNA Sequences in Ant Guts as a Method for Assessing Termite Predation by Ants. PLoS ONE, 10.(4): e0122533. https://doi.org/10.1371/journal.pone.0122533

Feinsinger, P. (1987) Effects of plant species on each other's pollination: Is community structure influenced? Trends in Ecology and Evolution, 2, 123-126.

Ferraro, P.J. \& Pattanayak, S.K. (2006) Money for nothing? A call for empirical evaluation of biodiversity conservation investments. Plos Biology, 4, 482-488.

Fitter, A.H. \& Fitter, R.S.R. (2002) Rapid changes in flowering time in British plants. Science, 296, 1689-1691.

Forrest, J.R.K. (2015) Plant-pollinator interactions and phenological change: what can we learn about climate impacts from experiments and observations? Oikos, 124, 4 13.

Forrest, J.R.K. (2017) Insect Pollinators and Climate Change. Global Climate Change and Terrestrial Invertebrates, pp. 69-91. John Wiley \& Sons, Ltd. 
Forup, M.L., Henson, K.S.E., Craze, P.G. \& Memmott, J. (2008) The restoration of ecological interactions: Plant-pollinator networks on ancient and restored heathlands. Journal of Applied Ecology, 45, 742-752.

Forup, M.L. \& Memmott, J. (2005) The restoration of plant-pollinator interactions in Hay meadows. Restoration Ecology, 13, 265-274.

Freitas, A.S., Arruda, V.A.S., Almeida-Muradian, L.B. \& Barth, O.M. (2013) The Botanical Profiles of Dried Bee Pollen Loads Collected by Apis mellifera (Linnaeus) in Brazil. Sociobiology, 60, 56 - 64.

Földesi, R., Kovács-Hostyánszki, A., Korösi, A., Somay, L., Elek, Z., Markó, V., Sárospataki, M., Bakos, R., Varga, A., Nyisztor, K. \& Báldi, A. (2015) Relationships between wild bees, hoverflies and pollination success in apple orchards with different landscape contexts. Agricultural and Forest Entomology. 18: 68-75. doi:10.1111/afe.12135

Galimberti, A., De Mattia, F., Bruni, I., Scaccabarozzi, D., Sandionigi, A., Barbuto, M., Casiraghi, M. \& Labr, M. (2014) A DNA Barcoding Approach to Characterize Pollen Collected by Honeybees. PLoS ONE, 9(10). e109363. https://doi.org/10.1371/journal.pone.0109363

Gallai, N., Salles, J. \& Settele, J. (2009) Economic valuation of the vulnerability of world agriculture confronted with pollinator decline. Ecological Economics, 68, 810 821.

Garcia-Robledo, C., Erickson, D.L., Staines, C.L., Erwin, T.L. \& Kress, W.J. (2013) Tropical Plant-Herbivore Networks: Reconstructing Species Interactions Using DNA Barcodes. Plos One, 8. (1): e52967. https://doi.org/10.1371/journal.pone.0052967

Garibaldi, L., Steffan-Dewenter, I., Winfree, R., Aizen, M., Bommarco, R., Cunningham, S., Kremen, C., Carvalheiro, L., Harder, L., Afik, O., Bartomeus, I., Benjamin, F., Boreux, V., Cariveau, D., Chacoff, N., Dudenhoffer, J., Freitas, B., Ghazoul, J., Greenleaf, S., Hipolito, J., Holzschuh, A., Howlett, B., Isaacs, R., Javorek, S., 
Kennedy, C., Krewenka, K., Krishnan, S., Mandelik, Y., Mayfield, M., Motzke, I., Munyuli, T., Nault, B., Otieno, M., Petersen, J., Pisanty, G., Potts, S., Rader, R., Ricketts, T., Rundlof, M., Seymour, C., Schuepp, C., Szentgyorgyi, H., Taki, H., Tscharntke, T., Vergara, C., Viana, B., Wanger, T., Westphal, C., Williams, N. \& Klein, A. (2013) Wild Pollinators Enhance Fruit Set of Crops Regardless of Honey Bee Abundance. Science, 339, 1608-1611.

Garibaldi, L.A., Steffan-Dewenter, I., Kremen, C., Morales, J.M., Bommarco, R., Cunningham, S.A., Carvalheiro, L.G., Chacoff, N.P., Dudenhoffer, J.H., Greenleaf, S.S., Holzschuh, A., Isaacs, R., Krewenka, K., Mandelik, Y., Mayfield, M.M., Morandin, L.A., Potts, S.G., Ricketts, T.H., Szentgyorgyi, H., Viana, B.F., Westphal, C., Winfree, R. \& Klein, A.M. (2011) Stability of pollination services decreases with isolation from natural areas despite honey bee visits. Ecology Letters, 14, 1062-1072.

Garratt, M.P.D., Coston, D.J., Truslove, C.L., Lappage, M.G., Polce, C., Dean, R., Biesmeijer, J.C. \& Potts, S.G. (2014) The identity of crop pollinators helps target conservation for improved ecosystem services. Biological Conservation, 169, 128-135.

Ghazoul, J. (2007) Challenges to the uptake of the ecosystem service rationale for conservation. Conservation Biology, 21, 1651 - 1652.

Gibson, R.H., Knott, B., Eberlein, T. \& Memmott, J. (2011) Sampling method influences the structure of plant-pollinator networks. Oikos, 120, 822-831.

Gibson, R.H., Nelson, I.L., Hopkins, G.W., Hamlett, B.J. \& Memmott, J. (2006) Pollinator webs, plant communities and the conservation of rare plants: Arable weeds as a case study. Journal of Applied Ecology, 43, 246-257.

Gilbert, F.S. (1981) Foraging ecology of hoverflies: morphology of the mouthparts in relation to feeding on nectar and pollen in some common urban species. Ecological Entomology, 6, 245 - 262. 
Gilbert, F.S. (1983) The foraging ecology of hoverflies (Diptera, Syrphidae): circular movements on composite flowers. Behavioural Ecology and Sociobiology, 13 (4), pp 253-257

Godfray, H.J.C. (2007) Linneaus in the information age. Nature, 446, 259 - 260.

Golding, Y. \& Edmunds, M. (2003) A novel method to investigate the pollen diets of hoverflies. Journal of Biological Education, 37, 182-185.

Golding, Y.C., Edmunds, M. \& Ennos, A.R. (2005) Flight behaviour during foraging of the social wasp Vespula vulgaris (Hymenoptera : Vespidae) and four mimetic hoverfiies (Diptera : Syrphidae) Sericomyia silentis, Myathropa florea, Helophilus sp and Syrphus sp. Journal of Experimental Biology, 208, 4523-4527.

Gordo, O. \& Sanz, J.J. (2006) Temporal trends in phenology of the honey bee Apis mellifera (L.) and the small white Pieris rapae (L.) in the Iberian Peninsula (19522004). Ecological Entomology, 31, 261-268.

Goulson, D. (1994) A model to predict the influence of insect flower constancy on interspecific competition between insect pollinated plants. Journal of Theoretical Biology, 168, 309 - 314.

Goulson, D. (1999) Foraging strategies for insects gathering nectar and pollen, and implications for plant ecology and evolution. Perspectives in Plant Ecology, Evolution and Systematics, 2, 185 - 209.

Goulson, D. (2000) Are Insects Flower Constant Because They Use Search Images to Find Flowers? Oikos, 88, 547-552.

Goulson, D., Nicholls, E. \& Botías, C.R., E.L. (2015) Bee declines driven by combined stress from parasites, pesticides, and lack of flowers. Science, 347. 1255957 DOI: 10.1126/science. 1255957

Goulson, D. \& Wright, N.P. (1998) Flower constancy in the hoverflies Episyrphus balteatus (Degeer) and Syrphus ribesii (L.) (Syrphidae). Behavioral Ecology, 9, $213-219$. 
Graham-Taylor, L.G., Stubbs, A.E. \& Brooke, M.d.L. (2009) Changes in phenology of hoverflies in a central England garden. Insect Conservation and Diversity, 2, 2935.

Grashof-Bokdam, C.J. \& van Langevelde, F. (2005) Green Veining: Landscape Determinants of Biodiversity in European Agricultural Landscapes. Landscape Ecology, 20, 417-439.

Gruter, C. \& Ratnieks, F.L.W. (2011) Flower constancy in insect pollinators: adaptive foraging or cognitive limitation? Communicative and Integrative Biology, 4, 633 636.

Gyan, K.Y. \& Woodell, S.R.J. (1987) Analysis of insect pollen loads and pollination efficiency of some common insect visitors of four species of woody Rosaceae. Functional Ecology, 1, 269-274.

Habel, J.C., Dengler, J., Janiskova, M., Torok, P., Wellstein, C. \& Wiezik, M. (2013) European grassland ecosystems:threatened hotspots of biodiversity. Biodiversity and Conservation, 22, 2131 - 2138.

Hails, R.S. \& Ormerod, S.J. (2013) Ecological science for ecosystem services and the stewardship of Natural Capital. Journal of Applied Ecology, 50, 807 - 811.

Hajibabaei, M., Singer, G.A.C., Hebert, P.D.N. \& Hickey, D.A. (2007) DNA barcoding: how it compliments taxonomy, molecular phylogenetics and population genetics. Trends in Genetics, 23, 167 - 172.

Hansen, K., Wacht, S., Seebauer, H. \& Schnuch, M. (1998) New aspects of chemoreception in flies. Olfaction and Taste Xii: an International Symposium, 855, 143-147.

Hardman, C.J., Harrison, D.P., Shaw, P.J., Nevard, T.D., Hughes, B., Potts, S.G. \& Norris, K. (2016) Supporting local diversity of habitats and species on farmland: a comparison of three wildlife-friendly schemes. Journal of Applied Ecology, 53, 171-180. 
Harvey, E., Gounand, I., Ward, C.L. \& Altermatt, F. (2016) Bridging ecology and conservation: from ecological networks to ecosystem function. Journal of Applied Ecology, 54: 371-379. doi:10.1111/1365-2664.12769

Haslett, J.R. (1983) A photographic account of pollen digestion by adult hoverflies. Physiological Entomolgy, 8, 167 - 171.

Haslett, J.R. (1989) Adult feeding by holometabolous insects: pollen and nectar as complementary nutrient sources for Rhingia campestris (Diptera: Syrphidae). Oecologia, 81, 361-363.

Hassall, C., Owen, J. \& Gilbert, F. (2016) Phenological shifts in hoverflies (Diptera: Syrphidae): linking measurement and mechanism. Ecography, 40: 853-863. doi:10.1111/ecog.02623

Hawkins, J., de Vere, N., Griffith, A., Ford, C.R., Allainguillaume, J., Hegarty, M.J., Baillie, L. \& Adams-Groom, B. (2015) Using DNA Metabarcoding to Identify the Floral Composition of Honey: A New Tool for Investigating Honey Bee Foraging Preferences. PLoS ONE, 10, e0134735.

Heal, G.M., Barbier, E.E., Boyle, K.J., Covich, A.P., Gloss, S.P. \& Hershner, C.H. (2005) Valuing Ecosystem Services: Toward Better Environmental Decision-Making. Washington, DC: The National Academies Press. https://doi.org/10.17226/11139.

Hebert, P.D.N., Cywinska, A., Ball, S.L. \& deWaard, J.R. (2003) Biological identifications through DNA barcodes. Proceedings of the Royal Society of London 270, 313 - 321.

Hebert, P.D.N., Penton, E.H., Burns, J.M., Janzen, D.H. \& Hallwachs, W. (2004) Ten species in one: DNA barcoding reveals cryptic species in the neotropical skipper butterfly Astraptes fulgerator. Proceedings of the National Academy of Sciences of the United States of America, 101, 14812-14817. 
Hegland, S.J. \& Boeke, L. (2006) Relationships between the density and diversity of floral resources and flower visitor activity in a temperate grassland community. Ecological Entomology, 31, 532-538.

Hegland, S.J., Nielsen, A., Lázaro, A., Bjerknes, A.L. \& Totland, Ø. (2009) How does climate warming affect plant-pollinator interactions? Ecology Letters, 12, 184195.

Hegland, S.J. \& Totland (2005) Relationships between species' floral traits and pollinator visitation in a temperate grassland. Oecologia, 145, 586-594.

Henter, H.J., Imondi, R., James, K., Spencer, D. \& Steinke, D. (2016) DNA barcoding in diverse educational settings: five case studies. Philosophical Transactions of the Royal Society B: Biological Sciences, 371. 20150340; DOI: 10.1098/rstb.2015.0340.

Hickman, J.M., Lövei, G.L. \& Wratten, S.D. (1995) Pollen feeding by adults of the hoverfly Melanostoma fasciatum (Diptera: Syrphidae). New Zealand Journal of Zoology, 22, 387-392.

Hoehn, P., Tscharntke, T., Tylianakis, J.M. \& Steffan-Dewenter, I. (2008) Functional group diversity of bee pollinators increases crop yield. Proceedings of the Royal Society B-Biological Sciences, 275, 2283-2291.

Hoiss, B., Krauss, J. \& Steffan-Dewenter, I. (2015) Interactive effects of elevation, species richness and extreme climatic events on plant-pollinator networks. Global Change Biology, 21, 4086-4097.

Holloway, B.A. (1976) Pollen-feeding in hover-flies (Diptera: Syrphidae). New Zealand Journal of Zoology, 3, 339 - 350.

Holmes, G., Sandbrook, C. \& Fisher, J. (2016) Understanding conservationists' perspectives on the new conservation debate. Conservation Biology. 31: 353-363. doi:10.1111/cobi.12811 
Holzschuh, A., Dainese, M., González-Varo, J.P., Mudri-Stojnić, S., Riedinger, V., Rundlöf, M., Scheper, J., Wickens, J.B., Wickens, V.J., Bommarco, R., Kleijn, D., Potts, S.G., Roberts, S.P.M., Smith, H.G., Vilà, M., Vujić, A. \& SteffanDewenter, I. (2016) Mass-flowering crops dilute pollinator abundance in agricultural landscapes across Europe. Ecology Letters, 19, 1228-1236.

Holzschuh, A., Dudenhoeffer, J.-H. \& Tscharntke, T. (2012) Landscapes with wild bee habitats enhance pollination, fruit set and yield of sweet cherry. Biological Conservation, 153, 101-107.

Howe, C., Suich, H., Vira, B. \& Mace, G.M. (2014) Creating win-wins from trade-offs? Ecosystem services for human well-being: a meta analysis of ecosystem service trade-offs and synergies in the real world. Global Environmental Change, 28, 263 $-275$.

Hudewenz, A., Klein, A.-M., Scherber, C., Stanke, L., Tscharntke, T., Vogel, A., Weigelt, A., Weisser, W.W. \& Ebeling, A. (2012) Herbivore and pollinator responses to grassland management intensity along experimental changes in plant species richness. Biological Conservation, 150, 42-52.

Iler, A.M., Inouye, D.W., Høye, T.T., Miller-Rushing, A.J., Burkle, L.A. \& Johnston, E.B. (2013) Maintenance of temporal synchrony between syrphid flies and floral resources despite differential phenological responses to climate. Global Change Biology, 19, 2348-2359.

Inouye, D.W., Larson, B.M.H., Ssymank, A. \& Kevan, P.G. (2015) Flies and Flower III: Ecology of Foraging and Pollination. Journal of Pollination Ecology, 16. 115-133

IPBES (2016) Summary for policymakers of the assessment report of the Intergovernmental Science-Policy Platform on Biodiversity and Ecosystem Services on pollinators, pollination and food production. (eds S.G. Potts, V.L. Imperatriz-Fonseca, H.T. Ngo, J.C. Biesmeijer, T.D. Breeze, L.V. Dicks, L.A. Garibaldi, R. Hill, J. Settele, A.J. Vanbergen, M.A. Aizen, S.A. Cunningham, C. Eardley, B.M. Freitas, N. Gallai, P.G. Kevan, A. Kovács-Hostyánszki, P.K. Kwapong, J. Li, X. Li, D.J. Martins, G. Nates-Parra, J.S. Pettis, R. Rader \& B.F. 
Viana), pp. 36 pages. Secretariat of the Intergovernmental Science-Policy

Platform on Biodiversity and Ecosystem Services, Bonn, Germany.

Irvin, N.A., Wratten, S.D., Frampton, C.M., Bowie, M.H., Evans, A.M. \& Moar, N.T. (1999) The phenology and pollen feeding of three hover fly (Diptera: Syrphidae) species in Canterbury, New Zealand. New Zealand Journal of Zoology, 26, 105 115.

Isbell, F., Calcagno, V., Hector, A., Connolly, J., Harpole, W.S., Reich, P.B., SchererLorenzen, M., Schmid, B., Tilman, D., van Ruijven, J., Weigelt, A., Wilsey, B.J., Zavaleta, E.S. \& Loreau, M. (2011) High plant diversity is needed to maintain ecosystem services. Nature, 477, 199-202.

Jarlan, A., De Oliveira, D. \& Gingras, J. (1997) Pollination by Eristalis tenax (Diptera : syrphidae) and seed set of greenhouse sweet pepper. Journal of Economic Entomology, 90, 1646-1649.

Jauker, B., Krauss, J., Jauker, F. \& Steffan-Dewenter, I. (2013) Linking life history traits to pollinator loss in fragmented calcareous grasslands. Landscape Ecology, 28, 107-120.

Jauker, F., Bondarenko, B., Becker, H.C. \& Steffan-Dewenter, I. (2012) Pollination efficiency of wild bees and hoverflies provided to oilseed rape. Agricultural and Forest Entomology, 14, 81-87.

Jauker, F., Diekotter, T., Schwarzbach, F. \& Wolters, V. (2009) Pollinator dispersal in an agricultural matrix: opposing responses of wild bees and hoverflies to landscape structure and distance from main habitat. Landscape Ecology, 24, 547-555.

Jauker, F. \& Wolters, V. (2008) Hoverflies are efficient pollinators of oilseed rape. Oecologia, 156, 819-823.

Jedrzejewska-Szmek, K. \& Zych, M. (2013) Flower-visitor and pollen transport networks in a large city: Structure and properties. Arthropod-Plant Interactions, 7, 503-516.

Jenkins, D. (1990) The Laws of Hywel Dda. Gomer Press, Llandysul. 
Jerrentrup, J.S., Wrage-Monnig, N., Rover, K. \& Isselstein, J. (2014) Grazing intensity affects insect diversity via sward structure and heterogeneity in a long-term experiment. Journal of Applied Ecology, 51, 968 - 977.

Jiron, L.F. \& Hedstrom, I. (1985) Pollination ecology of mango ( Mangifera indica L.) ( Anacardiaceae) in the Neotropic region. Turrialba, 35, 269-277.

JNCC (2016) UK Biodiversity Indicators 2015. Joint Nature Conservation Committee, London.

Jordano, P. (1987) Patterns of Mutualistic Interactions in Pollination and Seed Dispersal: Connectance, Dependence Asymmetries, and Coevolution. The American Naturalist, 129, 657-677.

Julier, H.E. \& Roulston, T.H. (2009) Wild Bee Abundance and Pollination Service in Cultivated Pumpkins: Farm Management, Nesting Behavior and Landscape Effects. Journal of Economic Entomology, 102, 563-573.

Juniper, T. (2013) What Has Nature Ever Done For Us? Profile Books, London.

Kaartinen, R., Stone, G.N., Hearn, J., Lohse, K. \& Roslin, T. (2010) Revealing secret liaisons: DNA barcoding changes our understanding of food webs. Ecological Entomology, 35, 623-638.

Kaiser-Bunbury, C.N., Memmott, J. \& Müller, C.B. (2009) Community structure of pollination webs of Mauritian heathland habitats. Perspectives in Plant Ecology, Evolution and Systematics, 11, 241-254.

Kaiser-Bunbury, C.N., Mougal, J., Whittington, A.E., Valentin, T., Gabriel, R., Olesen, J.M. \& Blüthgen, N. (2017) Ecosystem restoration strengthens pollination network resilience and function. Nature, 542, 223-227 doi:10.1038/nature21071

Kaloveloni, A., Tscheulin, T., Vujic, A., Radenkovic, S. \& Petanidou, T. (2015) Winners and losers of climate change for the genus Merodon (Diptera: Syrphidae) across the Balkan Peninsula. Ecological Modelling, 313, 201-211. 
Kareiva, P., Groves, C. \& Marvier, M. (2014) The evolving linkage between conservation science and practice at The Nature Conservancy. Journal of Applied Ecology, 51, $1137-1147$.

Kareiva, P. \& Marvier, M. (2011) Conservation Science: Balancing the Needs of People and Nature. Roberts and Co. Publishers.

Kartzinel, T.R., Chen, P.A., Coverdale, T.C., Erickson, D.L., Kress, W.J., Kuzmina, M.L., Rubenstein, D.I., Wang, W. \& Pringle, R.M. (2015) DNA metabarcoding illuminates dietary niche partitioning by African large herbivores. Proceedings of the National Academy of Sciences, 112, 8019-8024.

Kerr, J.T., Pindar, A., Galpern, P., Packer, L., Potts, S.G., Roberts, S.M., Rasmont, P., Schweiger, O., Colla, S.R., Richardson, L.L., Wagner, D.L., Gall, L.F., Sikes, D.S. \& Pantoja, A. (2015) Climate change impacts on bumblebees converge across continents. Science, 349, 177.

Kleijn, D. \& van Langevelde, F. (2006) Interacting effects of landscape context and habitat quality on flower visiting insects in agricultural landscapes. Basic and Applied Ecology, 7, 201-214.

Kleijn, D., Winfree, R., Bartomeus, I., Carvalheiro, L.G., Henry, M.I., Isaacs, R., Klein, A., Kremen, C., M’Gonigle, L.K., Rader, R., Ricketts, T.H., Williams, N.M., Adamson, N.L., Ascher, J.S., Baldi, A., Batary, P., Benjamin, F., Biesmeijer, J.C., Blitzer, E.J., Bommarco, R., Brand, M.R., Bretagnolle, V., Button, L., Cariveau, D.P., Chiffle, R., Colville, J.F., Danforth, B.N., Elle, E., Garratt, M.P.D., Herzog, F., Holzschuh, A., Howlett, B.G., Jauker, F., Jha, S., Knop, E., Krewenka, K.M., Le Feon, V., Mandelik, Y., May, E.A., Park, M.G., Pisanty, G., Reemer, M., Riedinger, V., Rollin, O., Rundlof, M., Sardinas, H.S., Scheper, J., Sciligo, A.R., Smith, H.G., Steffan-Dewenter, I., Thorp, R., Tscharntke, T., Verhulst, J., Viana, B.F., Vaissiere, B.E., Veldtman, R., Westphal, C. \& Potts, S.G. (2015) Delivery of crop pollination services is an insufficient argument for wild pollinator conservation. Nature Communications, 6. 7414 doi:10.1038/ncomms8414 
Klein, A., Vaissière, B.E., Cane, J.H., Steffan-Dewenter, I., Cunningham, S.A., Kremen, C. \& Tscharntke, T. (2007) Importance of pollinators in changing landscapes for world crops. Proceedings of the Royal Society B, 274, 303 - 313.

Klein, A.-M., Brittain, C., Hendrix, S.D., Thorp, R., Williams, N. \& Kremen, C. (2012) Wild pollination services to California almond rely on semi-natural habitat. Journal of Applied Ecology, 49, 723-732.

Kohler, F., Verhulst, J., Knop, E., Herzog, F. \& Kleijn, D. (2007) Indirect effects of grassland extensification schemes on pollinators in two contrasting European countries. Biological Conservation, 135, 302-307.

Kormann, U., Rösch, V., Batáry, P., Tscharntke, T., Orci, K.M., Samu, F. \& Scherber, C. (2015) Local and landscape management drive trait-mediated biodiversity of nine taxa on small grassland fragments. Diversity and Distributions, 21, 1204-1217.

Kovács-Hostyánszki, A., Espíndola, A., Vanbergen, A.J., Settele, J., Kremen, C. \& Dicks, L.V. (2017) Ecological intensification to mitigate impacts of conventional intensive land use on pollinators and pollination. Ecology Letters, 20: 673-689. doi:10.1111/ele.12762

Kraaijeveld, K., de Weger, L.A., Ventayol García, M., Buermans, H., Frank, J., Hiemstra, P.S. \& den Dunnen, J.T. (2015) Efficient and sensitive identification and quantification of airborne pollen using next-generation DNA sequencing. Molecular Ecology Resources, 15, 8-16.

Kremen, C., Williams, N.M. \& Aizen, M.A.G.-H., B.LeBuhn, G.Minckley, R.Packer, L.Potts, S.G.Roulston, T.Steffan-Dewenter, I.Vázquez, D.P.Winfree, R. Adams, L.Crone, E.E.Greenleaf, S.S.Keitt, T.H.Klein, A.Regetz, J.Ricketts, T.H. (2007) Pollination and other ecosystem services produced by mobile organisms: a conceptual framework for the effects of land-use change. Ecology Letters, 10, 299 $-314$.

Krenn, H.W., Plant, J.D. \& Szucsich, N.U. (2005) Mouthparts of flower-visiting insects. Arthropod Structure and Development, 34, 1 - 40. 
Krewenka, K.M., Holzschuh, A., Tscharntke, T. \& Dormann, C.F. (2011) Landscape elements as potential barriers and corridors for bees, wasps and parasitoids. Biological Conservation, 144, 1816-1825.

Kudo, G. \& Ida, T.Y. (2013) Early onset of spring increases the phenological mismatch between plants and pollinators. Ecology, 94, 2311-2320.

Kuhlmann, M., Guo, D., Veldtman, R. \& Donaldson, J. (2012) Consequences of warming up a hotspot: species range shifts within a centre of bee diversity. Diversity and Distributions, 18, 885-897.

Langowska, A., Zawilak, M., Sparks, T.H., Glazaczow, A., Tomkins, P.W. \& Tryjanowski, P. (2017) Long-term effect of temperature on honey yield and honeybee phenology. International Journal of Biometeorology, 61, 1125-1132.

Larson, B.M.H., Kevan, P.G. \& Inouye, D.W. (2001) Flies and Flowers: the taxonomic diversity of anthophiles and pollinators. Canadian Entomologist, 133, 439 - 465.

Lentini, P.E., Martin, T.G., Gibbons, P., Fischer, J. \& Cunningham, S.A. (2012) Supporting wild pollinators in a temperate agricultural landscape: Maintaining mosaics of natural features and production. Biological Conservation, 149, 84-92.

Liu, Y., Meeichun, D., Zhang, X., Zhang, X., Yu, Z. \& Axmacher, J.C. (2014) Effects of plant diversity, habitat and agricultural landscape structure on the functional diversity of carabid assemblages in the North China Plain. Insect Conservation and Diversity. 8: 163-176. doi:10.1111/icad.12096

Lunau, K. \& Wacht, S. (1994) Optical releasers of the innate proboscis extension in the hoverfly Eristalis tenax L (Syrphidae, Diptera). Journal of Comparative Physiology a-Sensory Neural and Behavioral Physiology, 174, 575-579.

Lye, G., Park, K., Osborne, J., Holland, J. \& Goulson, D. (2009) Assessing the value of Rural Stewardship schemes for providing foraging resources and nesting habitat for bumblebee queens (Hymenoptera: Apidae). Biological Conservation, 142, 2023-2032. 
Lázaro, A., Tscheulin, T., Devalez, J., Nakas, G., Stefanaki, A., Hanlidou, E. \& Petanidou, T. (2015) Moderation is best: effects of grazing intensity on plantflower visitor networks in Mediterranean communities. Ecological Applications. 26: 796-807. doi:10.1890/15-0202

Lüscher, G., Ammari, Y., Andriets, A., Angelova, S., Arndorfer, M., Bailey, D., Balázs, K., Bogers, M., Bunce, R.G.H., Choisis, J.-P., Dennis, P., Díaz, M., Dyman, T., Eiter, S., Fjellstad, W., Fraser, M., Friedel, J.K., Garchi, S., Geijzendorffer, I.R., Gomiero, T., González-Bornay, G., Guteva, Y., Herzog, F., Jeanneret, P., Jongman, R.H.G., Kainz, M., Kwikiriza, N., Díaz, M.L.L., Moreno, G., NicholasDavies, P., Nkwiine, C., Opio, J., Paoletti, M.G., Podmaniczky, L., Pointereau, P., Pulido, F., Sarthou, J.-P., Schneider, M.K., Sghaier, T., Siebrecht, N., Stoyanova, S., Wolfrum, S., Yashchenko, S., Albrecht, H., Báldi, A., Belényesi, M., BenhadiMarin, J., Blick, T., Buholzer, S., Centeri, C., Choisis, N., Cuendet, G., De Lange, H.J., Déjean, S., Deltshev, C., Cosín, D.J.D., Dramstad, W., Elek, Z., Engan, G., Evtushenko, K., Falusi, E., Finch, O.-D., Frank, T., Gavinelli, F., Genoud, D., Gillingham, P.K., Grónás, V., Gutiérrez, M., Häusler, W., Heer, X., Hübner, T., Isaia, M., Jerkovich, G., Jesus, J.B., Kakudidi, E., Kelemen, E., Koncz, N., Kovacs, E., Kovács-Hostyánszki, A., Last, L., Ljubomirov, T., Mandery, K., Mayr, J., Mjelde, A., Muster, C., Nascimbene, J., Neumayer, J., Ødegaard, F., Sánchez, F.J.O., Oschatz, M.-L., Papaja-Hülsbergen, S., Paschetta, M., Pavett, M., Pelosi, C., Penksza, K., Pommeresche, R., Popov, V., Radchenko, V., Richner, N., Riedel, S., Scullion, J., Sommaggio, D., Szalkovszki, O., Szerencsits, E., Trigo, D., Vale, J., van Kats, R., Vasilev, A., Whittington, A.E., Wilkes-Allemann, J. \& Zanetti, T. (2016) Farmland biodiversity and agricultural management on 237 farms in 13 European and 2 African regions. Ecology. 97: 1625. doi:10.1890/151985.1

Mace, G., Norris, K. \& Fitter, A. (2012) Biodiversity and ecosystem services: a multilayered relationship. Trends in Ecology \& Evolution, 27, 19-26.

Mace, G.M. (2014) Whose Conservation? Science, 345, 1558 - 1560. 
Mahy, G., Sloover, J.D. \& Jacquemart, A.-L. (1998) The generalist pollination system and reproductive success of Calluna vulgaris in the Upper Ardenne. Canadian Journal of Botany, 76, 1843-1851.

Mair, L., Thomas, C.D., Anderson, B.J., Fox, R., Botham, M. \& Hill, J.K. (2012) Temporal variation in responses of species to four decades of climate warming. Global Change Biology, 18, 2439-2447.

Mallinger, R.E. \& Gratton, C. (2015) Species richness of wild bees, but not the use of managed honeybees, increases fruit set of a pollinator-dependent crop. Journal of Applied Ecology, 52, 323-330.

Manfredo, M.J., Bruskotter, J.T., Teel, T.L., Fulton, D., Schwartz, S.H., Arlinghaus, R., Oishi, S., Uskul, A.K., Redford, K., Kitayama, S. \& Sullivan, L. (2016) Why social values cannot be changed for the sake of conservation. Conservation Biology, 31: 772-780. doi:10.1111/cobi.12855

Manhoudt, A.G.E. \& de Snoo, G.R. (2003) A quantitative survey of semi-natural habitats on Dutch arable farms. Agriculture, Ecosystems and Environment, 97, 235-240.

Marren, P. (2002) Nature Conservation. a review of the conservation of wildlife in Britain 1950 - 2001. Harper Collins, London.

Marrero, H.J., Torretta, J.P. \& Medan, D. (2014) Effect of land use intensification on specialization in plant-floral visitor interaction networks in the Pampas of Argentina. Agriculture, Ecosystems and Environment, 188, 63-71.

Marvin, W.P. (2006) Hunting law and Ritual in Medieval English Literature. D.S.Brewer, Cambridge.

Mayer, C., Adler, L., Armbruster, S., Dafni, A., Eardley, C., Huang, S., Kevan, P.G., Ollerton, J., Packer, L., Ssymank, A., Stout, J.C. \& Potts, S.G. (2011) Pollination ecology in the the 21 st century: key questions for future research. Journal of Pollination Ecology, 3, 8 - 23. 
McCallum, K.P., McDougall, F.O. \& Seymour, R.S. (2013) A review of the energetics of pollination biology. Journal of Comparative Physiology B-Biochemical Systemic and Environmental Physiology, 183, 867-876.

McCauley, D.J. (2006) Selling out on nature. Nature, 443, 27-28.

McGinlay, J., Parsons, D.J., Morris, J., Hubatova, M., Graves, A., Bradbury, R.B. \& Bullock, J.M. (2017) Do charismatic species groups generate more cultural ecosystem service benefits? Ecosystem Services, 27, Part A, 15-24.

McKenzie, A., Emery, S., Franks, J. \& Whittingham, M. (2013) Landscape-scale conservation: collaborative agri-environment schemes could benefit both biodiversity and ecosystem services, but will farmers be willing to participate? Journal of Applied Ecology, 50, 1274-1280.

MEA (2005) Ecosystems and Human Well-being: Synthesis. Washington D.C.

Meadows, D.H., Meadows, D.L., Randers, J. \& Behrens, W.W. (1972) Limits to Growth. Universe Books.

Memmott, J. (1999) The structure of a plant-pollinator food web. Ecology Letters, 2, 276280.

Meng, L.Z., Martin, K., Liu, J.X., Burger, F. \& Chen, J. (2012) Contrasting responses of hoverflies and wild bees to habitat structure and land use change in a tropical landscape (southern Yunnan, SW China). Insect Science, 19, 666-676.

Menzel, A., Sparks, T.H., Estrella, N., Koch, E., Aasa, A., Ahas, R., Alm-Kubler, K., Bissolli, P., Braslavska, O., Briede, A., Chmielewski, F.M., Crepinsek, Z., Curnel, Y., Dahl, A., Defila, C., Donnelly, A., Filella, Y., Jatcza, K., Mage, F., Mestre, A., Nordli, O., Penuelas, J., Pirinen, P., Remisova, V., Scheifinger, H., Striz, M., Susnik, A., Van Vliet, A.J.H., Wielgolaski, F.E., Zach, S. \& Zust, A. (2006) European phenological response to climate change matches the warming pattern. Global Change Biology, 12, 1969-1976. 
Meyer, B., Jauker, F. \& Steffan-Dewenter, I. (2009) Contrasting resource-dependent responses of hoverfly richness and density to landscape structure. Basic and Applied Ecology, 10, 178-186.

Meyer, S., Unternährer, D., Arlettaz, R., Humbert, J.-Y. \& Menz, M.H.M. (2017) Promoting diverse communities of wild bees and hoverflies requires a landscape approach to managing meadows. Agriculture, Ecosystems \& Environment, 239, 376-384.

Mitchell, A. (2008) DNA barcoding demystified. Australian Journal of Entomology, 47, 169-173.

Mitchell, R.J., Irwin, R.E., Flanagan, R.J. \& Karron, J.D. (2009) Ecology and evolution of plant-pollinator interactions. Annals of Botany, 103, 1355-1363.

Moore, C.D. \& Hassall, C. (2016) A bee or not a bee: an experimental test of acoustic mimicry by hoverflies. Behavioral Ecology.

Moriniere, J., de Araujo, B.C., Lam, A.W., Hausmann, A., Balke, M., Schmidt, S., Hendrich, L., Doczkal, D., Fartmann, B., Arvidsson, S. \& Haszprunar, G. (2016) Species Identification in Malaise Trap Samples by DNA Barcoding Based on NGS Technologies and a Scoring Matrix. Plos One, 11(5): e0155497. https://doi.org/10.1371/journal.pone.0155497

Moron, D., Szentgyorgyi, H., Wantuch, M., Celary, W., Westphal, C., Settele, J. \& Woyciechowski, M. (2008) Diversity of wild bees in wet meadows: implications for conservation. Wetlands, 28, 975-983.

Morris, R.K.A. (1998) Hoverflies of Surrey. Surrey Wildlife Trust, Woking.

Moss, S. (2004) A Bird in the Bush: a social history of birdwatching. Aurum Press.

Moyroud, E. \& Glover, B.J. (2016) The physics of pollinator attraction. New Phytologist, 216: 350-354. doi:10.1111/nph.14312 
Mukherjee, N., Sutherland, W.J., Dicks, L., Huge, J., Koedam, N. \& Dahdouh-Guebas, F. (2014) Ecosystem Service Valuations of Mangrove Ecosystems to Inform Decision Making and Future Valuation Exercises. PLoS ONE, 9, e107706. https://doi.org/10.1371/journal.pone.0107706

Nabhan, G.P. (1996) The dangers of reductionism in biodiversity conservation. Conservation Biology, 9, 479 - 481.

Nabhan, G.P. \& Buchmann, S.L. (1997) Services Provided by Pollinators. Nature's Services: Societal Dependence on Natural Ecosystems (ed. G.C. Daily). Island Press, Washington DC.

NBDC (2015) All-Ireland Pollinator Plan 2015 - 2020. Waterford.

Nicolson, S.W. \& Wright, G.A. (2017) Plant-pollinator interactions and threats to pollination: perspectives from the flower to the landscape. Functional Ecology, 31, 22-25.

Nuttman, C. \& Willmer, P. (2008) Hoverfly visitation in relation to floral colour change (Diptera : Syrphidae). Entomologia Generalis, 31, 33-47.

O'Neill, R.P. \& O'Neill, K.M. (2011) Pollen load composition and size in the leafcutting bee Megachile rotundata (Hymenoptera: Megachilidae). Apidologie, 42, 223-233.

Ockinger, E., Lindborg, R., Sjodin, N.E. \& Bommarco, R. (2012) Landscape matrix modifies richness of plants and insects in grassland fragments. Ecography, 35, 259-267.

Ockinger, E. \& Smith, H.G. (2007) Semi-natural grasslands as population sources for pollinating insects in agricultural landscapes. Journal of Applied Ecology, 44, 50 59.

Olesen, J.M., Bascompte, J., Dupont, Y.L. \& Jordano, P. (2007) The modularity of pollination networks. Proceedings of the National Academy of Sciences, 104, 19891-19896. 
Oliver, T.H., Heard, M.S., Isaac, N.J.B., Roy, D.B., Procter, D., Eigenbrod, F., Freckleton, R., Hector, A., Orme, C.D.L., Petchey, O.L., Proença, V., Raffaelli, D., Suttle, K.B., Mace, G.M., Martín-López, B., Woodcock, B.A. \& Bullock, J.M. (2015) Biodiversity and Resilience of Ecosystem Functions. Trends in Ecology \& Evolution, 11: 673 - 684

Ollerton, J. (1996) Reconciling Ecological Processes with Phylogenetic Patterns: The Apparent Paradox of Plant--Pollinator Systems. Journal of Ecology, 84, 767-769.

Ollerton, J., Alarcón, R., Waser, N.M., Price, M.V., Watts, S., Cranmer, L., Hingston, A., Peter, C.I. \& Rotenberry, J. (2009) A global test of the pollination syndrome hypothesis. Annals of Botany, 103, 1471-1480.

Ollerton, J., Erenler, H., Edwards, M. \& Crockett, R. (2014) Extinctions of aculeate pollinators in Britain and the role of large-scale agricultural changes. Science, $\mathbf{3 4 6}$, $1360-1362$.

Ollerton, J., Johnson, S.D., Cranmer, L. \& Kellie, S.A.M. (2003) The Pollination Ecology of an Assemblage of Grassland Asclepiads in South Africa. Annals of Botany, 92, 807-834.

Ollerton, J., Killick, A., Lamborn, E., Watts, S. \& Whiston, M. (2007) Multiple Meanings and Modes: On the Many Ways to Be a Generalist Flower. Taxon, 56, 717-728.

Ollerton, J., Price, V., Armbruster, W.S., Memmott, J., Watts, S., Waser, N.M., Totland, Ø., Goulson, D., Alarcón, R., Stout, J.C. \& Tarrant, S. (2012) Overplaying the role of honey bees as pollinators: a comment on Aebi and Neumann (2011). Trends in Ecology and Evolution, 27, 141-142.

Ollerton, J., Rech, A.R., Waser, N.M. \& Price, M.V. (2015) Using the literature to test pollination syndromes - some methodological cautions. Journal of Pollination Ecology, 16, 119 - 125.

Ollerton, J., Winfree, R. \& Tarrant, S. (2011) How many flowering plants are pollinated by animals? Oikos, 120, 321-326. 
Orford, K.A., Murray, P.J., Vaughan, I.P. \& Memmott, J. (2016) Modest enhancements to conventional grassland diversity improve the provision of pollination services. Journal of Applied Ecology, 53, 906 - 915.

Ormerod, S.J. (2014) Rebalancing the philosophy of river conservation. Aquatic Conservation: Marine and Freshwater ecosystems, 24, 147 - 152.

Osborne, J.L., Martin, A.P., Carreck, N.L., Swain, J.L., Knight, M.E., Goulson, D., Hale, R.J. \& R.A., S. (2008) Bumblebee flight distances in relation to the forage landscape Journal of Animal Ecology, 77, 406 - 415.

Ouin, A., Sarthou, J.P., Bouyjou, B., Deconchat, M., Lacombe, J.P. \& Monteil, C. (2006) The species-area relationship in the hoverfly (Diptera, Syrphidae) communities of forest fragments in southern France. Ecography, 29, 183-190.

Ovaskainen, O., Skorokhodova, S., Yakovleva, M., Sukhov, A., Kutenkov, A., Kutenkova, N., Shcherbakov, A., Meyke, E. \& Delgado, M.d.M. (2013) Community-level phenological response to climate change. Proceedings of the National Academy of Sciences, 110, 13434-13439.

Pansarin, E.R. (2008) Reproductive biology and pollination of Govenia utriculata: A syrphid fly orchid pollinated through a pollen-deceptive mechanism. Plant Species Biology, 23, 90-96.

Parducci, L., Suyama, Y., Lascoux, M. \& Bennett, K. (2005) Ancient DNA from pollen: a genetic record of population history in Scots pine. Molecular Ecology, 14, 28732882.

Parmenter, L. (1958) Flies (Diptera) and their relationships with plants. Nature, 37, 115 125.

Parmesan, C. \& Yohe, G. (2003) A globally coherent fingerprint of climate change impacts across natural systems. Nature, 421, 37-42.

Pearson, R.G. (2016) Reasons to Conserve Nature. Trends in Ecology \& Evolution, 31, $366-371$. 
Penney, H.D., Hassall, C., Skevington, J.H., Abbott, K.R. \& Sherratt, T.N. (2012) A comparative analysis of the evolution of imperfect mimicry. Nature, 483, 461464.

Petanidou, T., Kallimanis, A.S., Tzanopoulos, J., Sgardelis, S.P. \& Pantis, J.D. (2008) Long-term observation of a pollination network: Fluctuation in species and interactions, relative invariance of network structure and implications for estimates of specialization. Ecology Letters, 11, 564-575.

Petersen, G., Johansen, B. \& Seberg, O. (1996) PCR and sequencing from a single pollen grain. Plant Molecular Biology, 31, 189-191.

Pinheiro, L.A., Torres, L.M., Raimundo, J. \& Santos, S.A.P. (2015) Effects of pollen, sugars and honeydew on lifespan and nutrient levels of Episyrphus balteatus. Biocontrol, 60, 47-57.

Pires, A.C. \& Marinoni, L. (2010) DNA barcoding and traditional taxonomy unified through Integrative Taxonomy: a view that challenges the debate questioning both methodologies. Biota Neotropica, 10, 339-346.

Pontin, D.R., Wade, M.R., Kehrli, P. \& Wratten, S.D. (2006) Attractiveness of single and multiple species flower patches to beneficial insects in agroecosystems. Annals of Applied Biology, 148, 39-47.

Potts, S., Biesmeijer, J., Kremen, C., Neumann, P., Schweiger, O. \& Kunin, W. (2010) Global pollinator declines: trends, impacts and drivers. Trends in Ecology and Evolution, 25, 345-353.

Potts, S.G., Imperatriz-Fonseca, V., Ngo, H.T., Aizen, M.A., Biesmeijer, J.C., Breeze, T.D., Dicks, L.V., Garibaldi, L.A., Hill, R., Settele, J. \& Vanbergen, A.J. (2016) Safeguarding pollinators and their values to human well-being. Nature. 540, 220 229 doi:10.1038/nature20588 
Power, E.F., Jackson, Z. \& Stout, J.C. (2016) Organic farming and landscape factors affect abundance and richness of hoverflies (Diptera, Syrphidae) in grasslands. Insect Conservation and Diversity, 9, 244 - 253.

Power, E.F., Kelly, D.L. \& Stout, J.C. (2012) Organic Farming and Landscape Structure: Effects on Insect-Pollinated Plant Diversity in Intensively Managed Grasslands. Plos One, 7(5): e38073. https://doi.org/10.1371/journal.pone.0038073

Praz, C.J., Müller, A. \& Dorn, S. (2008) Host recognition in a pollen-specialist bee: evidence for a genetic basis. Apidologie, 39. 547-557 DOI: 10.1051/apido:2008034

Primante, C. \& Dotterl, S. (2010) A Syrphid Fly Uses Olfactory Cues to Find a NonYellow Flower. Journal of Chemical Ecology, 36, 1207-1210.

Prodorutti, D. \& Frilli, F. (2008) Entomophilous pollination of raspberry, red currant and highbush blueberry in a mountain area of Friuli-Venezia Giulia (north-eastern Italy). Proceedings of the Ixth International Rubus and Ribes Symposium (eds P. Banados \& A. Dale), pp. 429-434.

Pullin, A.S. \& Knight, T.M. (2009) Doing more good than harm - Building an evidencebase for conservation and environmental management. Biological Conservation, 142, 931-934.

Pyke, G.H. (2016) Floral Nectar: Pollinator Attraction or Manipulation? Trends in Ecology \& Evolution, 31, 339-341.

Pywell, R.F., Heard, M.S., Woodcock, B.A., Hinsley, S., Ridding, L., Nowakowski, M. \& Bullock, J.M. (2015) Wildlife-friendly farming increases crop yield: evidence for ecological intensification. Proceedings of the Royal Society - B, 282, 20151740.

Radenkovic, S., Vujic, A., Stahls, G., Perez-Banon, C., Rojo, S., Petanidou, T. \& Simic, S. (2011) Three new cryptic species of the genus Merodon Meigen (Diptera: Syrphidae) from the island of Lesvos (Greece). Zootaxa, 2735: 35-56. 
Radenković, S., Schweiger, O., Milić, D., Harpke, A. \& Vujić, A. (2017) Living on the edge: Forecasting the trends in abundance and distribution of the largest hoverfly genus (Diptera: Syrphidae) on the Balkan Peninsula under future climate change. Biological Conservation, 212, Part A, 216-229.

Rader, R., Edwards, W., Westcott, D.A., Cunningham, S.A. \& Howlett, B.G. (2011) Pollen transport differs among bees and flies in a human-modified landscape. Diversity and Distributions, 17, 519-529.

Rader, R., Howlett, B.G., Cunningham, S.A., Westcott, D.A., Newstrom-Lloyd, L.E., Walker, M.K., Teulon, D.A.J. \& Edwards, W. (2009) Alternative pollinator taxa are equally efficient but not as effective as the honeybee in a mass flowering crop. Journal of Applied Ecology, 46, 1080-1087.

Ramsden, M., Menendez, R., Leather, S. \& Wäckers, F. (2016) Do natural enemies really make a difference? Field scale impacts of parasitoid wasps and hoverfly larvae on cereal aphid populations. Agricultural and Forest Entomology, DOI: 10.1111/afe.12191.

Rangathan, J., Raudsepp-Hearne, C., Lucas, N., Irwin, F., Zurek, M., Bennett, K., Ash, N. \& West, P. (2008) Ecosystem Services: A Guide for Decision Makers. World Resources Institute.

Rasmussen, L.V., Christensen, A.E., Danielsen, F., Dawson, N., Martin, A., Mertz, O., Sikor, T., Thongmanivong, S. \& Xaydongvanh, P. (2016) From food to pest: Conversion factors determine switches between ecosystem services and disservices. Ambio, 46(2):173-183. doi: 10.1007/s13280-016-0813-6.

Ricarte, A., Marcos-Garcia, M.A. \& Moreno, C.E. (2011) Assessing the effects of vegetation type on hoverfly (Diptera: Syrphidae) diversity in a Mediterranean landscape: implications for conservation. Journal of Insect Conservation, 15, 865877.

Richardson, R.T., Lin, C.-H., Sponsler, D.B., Quijia, J.O., Goodell, K. \& Johnson, R.M. (2015) Application of ITS2 metabarcoding to determine the provenance of pollen 
collected by honey bees in an agroecosystem. Applications in Plant Sciences, 3(1), apps.1400066. http://doi.org/10.3732/apps.1400066

Ricketts, T.H., Regetz, J., Steffan-Dewenter, I., Cunningham, S.A., Kremen, C., Bogdanski, A., Gemmill-Herren, B., Greenleaf, S.S., Klein, A.M., Mayfield, M.M., Morandin, L.A., Ochieng, A., Potts, S.G. \& Viana, B.F. (2008) Landscape effects on crop pollination services: are there general patterns? Ecology Letters, 11, 499 - 515.

Ricketts, T.H., Watson, K.B., Koh, I., Ellis, A.M., Nicholson, C.C., Posner, S., Richardson, L.L. \& Sonter, L.J. (2016) Disaggregating the evidence linking biodiversity and ecosystem services. Nature Communications, 7, 13106. doi:10.1038/ncomms13106

Ridding, L.E., Redhead, J.W. \& Pywell, R.F. (2015) Fate of semi-natural grassland in England between 1960 and 2013: A test of national conservation policy. Global Ecology and Conservation, 4, 516-525.

Rodwell, J., Pigott, C.D., Ratcliffe, D.A., Malloch, A.J.C., Birks, H.J.B., Proctor, M.C.F., Shimwell, D.W., Huntley, J.P., Radford, E., Wigginton, M.J. \& Wilkins, P. (1992) British Plant Communities Volume 3: Grasslands and montane communities. Cambridge University Press, Cambridge.

Ronca, S., Allainguillaume, J., Ford, C.S., Warren, J. \& Wilkinson, M.J. (2017) GM Risk Assessment: pollen carriage from Brassica napus to B. rapa varies widely between pollinators. Basic and Applied Ecology. 19, 36-44

Rosa García, R. \& Miñarro, M. (2014) Role of floral resources in the conservation of pollinator communities in cider-apple orchards. Agriculture, Ecosystems \& Environment, 183, 118-126.

Rosas-Guerrero, V., Aguilar, R., Martén-Rodríguez, S.A., L.Lopezaraiza-Mikel, M. \& Bastida, J.M.Q., M. (2014) A quantitative review of pollination syndromes: do floral traits predict effective pollinators? Ecology Letters, 17, 388 - 400. 
Rosch, V., Tscharntke, T., Scherber, C. \& Bata, P. (2013) Landscape composition, connectivity and fragment size drive effects of grassland fragmentation on insect communities. Journal of Applied Ecology, 50, 387 - 394.

Rotheray, G.E. \& Gilbert, F. (2011) The Natural History of Hoverflies. Forrest Text, Cardigan.

Roussel, J.-M., Paillisson, J.-M., Tréguier, A. \& Petit, E. (2015) The downside of eDNA as a survey tool in water bodies. Journal of Applied Ecology, 52, 823-826.

Rundlof, M., Andersson, G.K.S., Bommarco, R., Fries, I., Hederstrom, V., Herbertsson, L., Jonsson, O., Klatt, B.K., Pedersen, T.R., Yourstone, J. \& Smith, H.G. (2015) Seed coating with a neonicotinoid insecticide negatively affects wild bees. Nature, 521, 77-80.

Rzanny, M. \& Voigt, W. (2012) Complexity of multitrophic interactions in a grassland ecosystem depends on plant species diversity. Journal of Animal Ecology, 81, 614-627.

Sakata, Y., Sakaguchi, S. \& Yamasaki, M. (2014) Does community-level floral abundance affect the pollination success of a rewardless orchid, Calanthe reflexa Maxim.? Plant Species Biology, 29, 159-168.

Samnegård, U., Hambäck, P.A., Lemessa, D., Nemomissa, S. \& Hylander, K. (2016) A heterogeneous landscape does not guarantee high crop pollination. Proceedings of the Royal Society B: Biological Sciences, 283. 20161472; DOI: 10.1098/rspb.2016.1472.

Sardiñas, H.S., Tom, K., Ponisio, L.C., Rominger, A. \& Kremen, C. (2015) Sunflower (Helianthus annuus) pollination in California's Central Valley is limited by native bee nest site location. Ecological Applications. 26: 438-447. doi:10.1890/15-0033

Sarma, K., Tandon, R., Shivanna, K.R. \& Ram, H.Y.M. (2007) Snail-pollination in Volvulopsis nummularium. Current Science, 93, 826 - 831. 
Saunders, M.E. \& Luck, G.W. (2016) Limitations of the Ecosystem Services versus Disservices Dichotomy. Conservation Biology, 30: 1363-1365. doi:10.1111/cobi.12740

SCEP (1970) Man's impact on the Global Environment: assessment and recommendations for action. MIT. Cambridge, Mass.

Schaffers, A.P., Raemakers, I.P., Sykora, K.V. \& Ter Braak, C.J.F. (2008) Arthropod assemblages are best predicted by plant species composition. Ecology, 89, 782794.

Scharks, T. \& Masuda, Y.J. (2016) Valuing nature isn't evil. Conservation Letters. 9: 3-4. doi:10.1111/conl.12234

Schenk, M., Krauss, J. \& Holzschuh, A. (2017) Desynchronizations in bee-plant interactions cause severe fitness losses in solitary bees. Journal of Animal Ecology, 1-11. https://doi.org/10.1111/1365-2656.12694

Scheper, J., Reemer, M., van Kats, R., Ozinga, W.A., van der Linden, G.T.J., Schaminée, J.H.J., Siepel, H. \& Kleijn, D. (2014) Museum specimens reveal loss of pollen host plants as key factor driving wild bee decline in The Netherlands. Proceedings of the National Academy of Sciences, 111, 17552-17557.

Schnell, I.B., Fraser, M., Willerslev, E. \& Gilbert, M.T.P. (2010) Characterisation of insect and plant origins using DNA extracted from small volumes of bee honey. Arthropod-Plant Interactions, 4, 107-116.

Schuepp, C., Herrman, J.D., Herzog, F. \& Schmidt-Entling, M.H. (2011) Differential effects of habitat isolation and landscape composition on wasps, bees and their enemies. Oecologia, 165, 713 - 721.

Schumacher, E.F. (1973) Small is Beautiful. A study of economics as if people mattered. Blond and Briggs.

Schweiger, O., Musche, M., Bailey, D., Billeter, R., Diekotter, T., Hendrickx, F., Herzog, F., Liira, J., Maelfait, J.P., Speelmans, M. \& Dziock, F. (2007) Functional 
richness of local hoverfly communities (Diptera, Syrphidae) in response to land use across temperate Europe. Oikos, 116, 461-472.

Seifan, M., Hoch, E.-M., Hanoteaux, S. \& Tielbörger, K. (2014) The outcome of shared pollination services is affected by the density and spatial pattern of an attractive neighbour. Journal of Ecology, 102, 953-962.

Senapathi, D., Goddard, M.A., Kunin, W.E. \& Baldock, K.C.R. (2017) Landscape impacts on pollinator communities in temperate systems: evidence and knowledge gaps. Functional Ecology, 31, 26-37.

Shackleton, C.M., Ruwanza, S., Sinasson Sanni, G.K., Bennett, S., De Lacy, P., Modipa, R., Mtati, N., Sachikonye, M. \& Thondhlana, G. (2016) Unpacking Pandora's Box: Understanding and Categorising Ecosystem Disservices for Environmental Management and Human Wellbeing. Ecosystems, 19, 587-600.

Sharma, M. (1970) An Analysis of Pollen Loads of Honey Bees from Kangra, India. Grana, 10, 35 - 42.

Shrestha, M., Lunau, K., Dorin, A., Schulze, B., Bischoff, M., Burd, M. \& Dyer, A.G. (2016) Floral colours in a world without birds and bees: the plants of Macquarie Island. Plant Biology, 18: 842-850. doi:10.1111/plb.12456.

Sickel, W., Ankenbrand, M.J., Grimmer, G., Holzschuh, A., Härtel, S., Lanzen, J., Steffan-Dewenter, I. \& Keller, A. (2015) Increased efficiency in identifying mixed pollen samples by meta-barcoding with a dual-indexing approach. BMC Ecology, 15, 20. https://doi.org/10.1186/s12898-015-0051-y

Silvertown, J. (2015) Have Ecosystem Services Been Oversold? Trends in Ecology and Evolution, 30, 641-648

Simons, N.K., Gossner, M.M., Lewinsohn, T.M., Lange, M., Turke, M. \& Weisser, W.W. (2015) Effects of land-use intensity on arthropod species abundance distributions in grasslands. Journal of Animal Ecology, 84, 143 - 154. 
Sjodin, N.E., Bengtsson, J. \& Ekbom, B. (2008) The influence of grazing intensity and landscape composition on the diversity and abundance of flower-visiting insects. Journal of Applied Ecology, 45, 763-772.

Slade, E., Merckx, T., Riutta, T., Bebber, D., Redhead, D., Riordan, P. \& Macdonald, D. (2013) Life-history traits and landscape characteristics predict macro-moth responses to forest fragmentation. Ecology, 94, 1519-1530.

Smith, M.R., Singh, G.M., Mozzaffarian, D. \& Myers, S.S. (2015) Effects of decreases of animal pollinators on human nutrition and global health: a modelling analysis. The Lancet, 386, 1964 - 1972.

Smith, R.S., Shiel, R.S., Bardgett, R.D., Millward, D., Corkhill, P., Rolph, G., Hobbs, P.J. \& Peacock, S. (2003) Soil microbial community, fertility, vegetation and diversity as targets in the restoration management of a meadow grassland. Journal of Applied Ecology, 40, 51-64.

Smith, T.J. \& Saunders, M.E. (2016) Honey bees: the queens of mass media, despite minority rule among insect pollinators. Insect Conservation and Diversity, 9, 384390.

Song, Z. \& Feldman, M.W. (2013) Adaptive foraging behaviour of individual pollinators and the coexistence of co-flowering plants. Proceedings of the Royal Society - B, 281, 20132437.

Sparks, T.H., Langowska, A., Glazaczow, A., Wilkaniec, Z., Bienkowska, M. \& Tryjanowski, P. (2010) Advances in the timing of spring cleaning by the honeybee Apis mellifera in Poland. Ecological Entomology, 35, 788-791.

Ssymank, A. \& Gilbert, F. (1993) Anemophilous pollen in the diet of syrphid flies with special reference to the leaf feeding strategy occurring in Xylotini (Diptera: Syrphidae). Deutsche Entomologische Zeitschrift, 40, 245 - 258.

Stamp, D. (1969) Nature Conservation in Britain. Collins. 
Stanley, D.A., Gunning, D. \& Stout, J.C. (2013) Pollinators and pollination of oilseed rape crops (Brassica napus L.) in Ireland: ecological and economic incentives for pollinator conservation. Journal of Insect Conservation, 17, 1181-1189.

Stavert, J.R., Liñán-Cembrano, G., Beggs, J.R., Howlett, B.G., Pattemore, D.E. \& Bartomeus, I. (2016) Hairiness: the missing link between pollinators and pollination. PeerJ, 4, e2779. https://doi.org/10.7717/peerj.2779

Steffan-Dewenter, I. \& Westphal, C. (2008) The interplay of pollinator diversity, pollination services and landscape change. Journal of Applied Ecology, 45, 737741.

Stelleman, P. \& Meeuse, A.D.J. (1976) Anthecological relations between reputedly anemophilous flowers and syrphid flies. I. The possible role of syrphid flies as pollinators of Plantago. Tijdschrift Voor Entomologie, 119, 95 - 119.

Stiles, F.G. (1975) Ecology, Flowering Phenology, and Hummingbird Pollination of Some Costa Rican Heliconia Species. Ecology, 56, 285-301.

Stokl, J., Brodmann, J., Dafni, A., Ayasse, M. \& Hansson, B.S. (2011) Smells like aphids: orchid flowers mimic aphid alarm pheromones to attract hoverflies for pollination. Proceedings of the Royal Society B-Biological Sciences, 278, 12161222.

Stubbs, A.E. \& Falk, S.J. (2002) British Hoverflies. An illustrated identification guide. British Hoverflies. An illustrated identification guide. BENHS, Reading.

Sutcliffe, L.M.E., Batáry, P., Becker, T., Orci, K.M. \& Leuschner, C. (2015) Both local and landscape factors determine plant and Orthoptera diversity in the semi-natural grasslands of Transylvania, Romania. Biodiversity and Conservation, 24, 229 245.

Sutherland, J.P., Sullivan, M.S. \& Poppy, G.M. (1999) The influence of floral character on the foraging behaviour of the hoverfly, Episyrphus balteatus. Entomologia Experimentalis Et Applicata, 93, 157-164. 
Sutherland, W.J., Gardner, T., Bogich, T.L., Bradbury, R.B., Clothier, B., Jonsson, M., Kapos, V., Lane, S.N., Möller, I., Schroeder, M., Spalding, M., Spencer, T., White, P.C.L. \& Dicks, L.V. (2014) Solution scanning as a key policy tool: identifying management interventions to help maintain and enhance regulating ecosystem services. Ecology and Society, 19 (2): 3. http://dx.doi.org/10.5751/ES06082-190203

Sutherland, W.J., Pullin, A.S., Dolman, P.M. \& Knight, T.M. (2004) The need for evidence-based conservation. Trends in Ecology \& Evolution, 19, 305-308.

Taberlet, P., Coissac, E., Pompanon, F., Brochmann, C. \& Willerslev, E. (2012) Towards next-generation biodiversity assessment using DNA metabarcoding. Molecular Ecology, 21, 2045 - 2250.

Tadey, M. (2015) Indirect effects of grazing intensity on pollinators and floral visitation. Ecological Entomology, 40, 451-460.

Tautz, D., Arctander, P., Minelli, A., Thomas, R.H. \& Vogler, A.P. (2003) A plea for DNA taxonomy. Trends in Ecology and Evolution, 18, 70 - 74.

Taylor, C.H., Reader, T. \& Gilbert, F. (2016) Why many Batesian mimics are inaccurate: evidence from hoverfly colour patterns. Proceedings of the Royal Society B: Biological Sciences, 283. 20161585; DOI: 0.1098/rspb.2016.1585

TEEB (2010) The Economics of Ecosystems and Biodiversity: Mainstreaming the Economics of Nature: A synthesisof the approach, conclusions and recommendations of TEEB.

Tiusanen, M., Hebert, P.D., Schmidt, N.M. \& Roslin, T. (2016) One fly to rule them allmuscid flies are the key pollinators in the Arctic. Proceedings of the Royal Society B Biol Sci, 283 20161271; DOI: 10.1098/rspb.2016.1271

Traveset, A. \& Sáez, E. (1997) Pollination of Euphorbia dendroides by lizards and insects: Spatio-temporal variation in patterns of flower visitation. Oecologia, 111, 241-248. 
Traveset, A., Tur, C. \& Eguiluz, V.M. (2017) Plant survival and keystone pollinator species in stochastic coextinction models: role of intrinsic dependence on animalpollination. Scientific Reports, 7, 6915. doi:10.1038/s41598-017-07037-7

Turnbull, L.A., Isbell, F., Purves, D.W., Loreau, M. \& Hector, A. (2016) Understanding the value of plant diversity for ecosystem functioning through niche theory. Proceedings of the Royal Society B: Biological Sciences, 283. 20160536; DOI: $10.1098 / \mathrm{rspb} .2016 .0536$

Vamosi, J.C., Gong, Y.-B., Adamowicz, S.J. \& Packer, L. (2016) Forecasting pollination declines through DNA barcoding: the potential contributions of macroecological and macroevolutionary scales of inquiry. New Phytologist, 214: 11-18. doi:10.1111/nph.14356

Verdu, J.R., Morenob, C.E., Sanchez-Rojasb, G., Numaa, C., Galantea, E. \& Halffterc, G. (2007) Grazing promotes dung beetle diversity in the xeric landscapeof a Mexican Biosphere Reserve. Biological Conservation, 140, 308 - 317.

Vesterinen, E.J., Lilley, T., Laine, V.N. \& Wahlberg, N. (2013) Next Generation Sequencing of Fecal DNA Reveals the Dietary Diversity of the Widespread Insectivorous Predator Daubenton's Bat (Myotis daubentonii) in Southwestern Finland. Plos One, 8(11): e82168. https://doi.org/10.1371/journal.pone.0082168

Vickery, J.A., Tallowin, J.R., Feber, R.E., Asteraki, E.J., Atkinson, P.W., Fuller, R.J. \& Brown, V.K. (2001) The management of lowland neutral grasslands in Britain: effects of agricultural practices on birds and their food resources. Journal of Applied Ecology, 38, 647-664.

Vucetich, J.A., Nelson, M.P. \& Bruskotter, J.T. (2015) Evaluating whether nature's intrinsic value is an axiom of or anathema to conservation. Conservation Biology. 29: 321-332. doi:10.1111/cobi.12464

Vázquez, D.P., Blüthgen, N., Cagnolo, L. \& Chacoff, N.P. (2009) Uniting pattern and process in plant-animal mutualistic networks: a review. Annals of Botany, 103, $1445-1457$. 
Wacht, S., Lunau, K. \& Hansen, K. (2000) Chemosensory control of pollen ingestion in the hoverfly Eristalis tenax by labellar taste hairs. Journal of Comparative Physiology A, 186, 193-203.

Wardhaugh, C.W. (2015) How many species of arthropods visit flowers? ArthropodPlant Interactions, 9, 547-565.

Waser, N.M. (1978) Interspecific pollen transfer and competition between co-occurring plant species. Oecologia, 36, 223-236.

Waser, N.M., Chittka, L., Price, M.V., Williams, N.M. \& Ollerton, J. (1996)

Generalization in Pollination Systems, and Why it Matters. Ecology, 77, 10431060 .

Waser, N.W. (1986) Flower Constancy: definition, cause and measurement. American Naturalist, 127, 593 - 603.

Weiner, C.N., Werner, M., Linsenmair, K.E. \& Blüthgen, N. (2014) Land-use impacts on plant-pollinator networks: interaction strength and specialization predict pollinator declines. Ecology, 95, 466-474.

Welsh Government (2013) An Action Plan for Pollinators. Welsh Government, Aberystwyth.

Westman, W.E. (1977) How Much are Nature's Services Worth? Science, 197, 960 - 964.

Wiens, D., Rourke, J.P., Casper, B.B., Rickart, E.A., LaPine, T.R., Peterson, C.J. \& Channing, A. (1983) Nonflying Mammal Pollination of Southern African Proteas: A Non-Coevolved System. Annals of the Missouri Botanical Garden, 70, 1-31.

Willmer, P. (2011) Pollination and Floral Ecology. Princeton University Press, Princeton, New Jersey.

Wilson, E.E., Sidhu, C.S., LeVan, K.E. \& Holway, D.A. (2010) Pollen foraging behaviour of solitary Hawaiian bees revealed through molecular pollen analysis. Molecular Ecology, 19, 4823-4829. 
Wong, E.H.K. \& Hanner, R.H. (2008) DNA barcoding detects market substitution in North American seafood. Food Research International, 4, 828 - 837.

Wong, M.M., Lim, C.L. \& Wilson, J.J. (2015) DNA barcoding implicates 23 species and four orders as potential pollinators of Chinese knotweed (Persicaria chinensis) in Peninsular Malaysia. Bulletin of Entomological Research, 105, 515-520.

Woodcock, T.S., Larson, B.M.H., Kevan, P.G., Inouye, D.W. \& Lunau, K. (2014) Flies and Flowers II: Floral Attractants and Rewards. Journal of Pollination Ecology 12.

http://www.pollinationecology.org/index.php?journal=jpe\&page=article\&op=vie w\&path $\% 5 \mathrm{~B} \% 5 \mathrm{D}=231$.

Wynne, G. \& Avery, M. (1995) Biodiversity Challenge: An Agenda for Conservation in the UK. RSPB. ISBN: 0903138808

Yu, D.W., Ji, Y., Emerson, B.C., Wang, X., Ye, C., Yang, C. \& Ding, Z. (2012) Biodiversity soup: metabarcoding of arthropods for rapid biodiversity assessment and biomonitoring. Methods in Ecology and Evolution, 3, 613 - 623. 


\section{Chapter 2}

\section{Flower resource and land management drives}

\section{hoverfly communities and bee abundance in semi- natural and agricultural grasslands}

Lucas A., Bull J.C., de Vere N., Neyland P.J., and Forman D.W.

(2017) Flower resource and land management drives hoverfly

communities and bee abundance in seminatural and agricultural

grasslands. Ecology and Evolution 1-14 DOI: 10.1002/ece3.3303.

Andrew Lucas conceived the study, undertook fieldwork, all data collection, statistical analysis, and drafted the manuscript. James C Bull undertook statistical analysis, and drafting of manuscript. Natasha de Vere advised on drafting the manuscript. Penelope J Neyland advised on statistical analysis and drafting the manuscript. Dan W Forman helped to conceive the study, advised on statistical analysis, and drafted the manuscript. 


\section{Summary}

1. Pollination is a key ecosystem service, and appropriate management, particularly in agricultural systems, is essential to maintain a diversity of pollinator guilds. However, management recommendations frequently focus on maintaining plant communities, with the assumption that associated invertebrate populations will be sustained.

2. We tested whether plant community, flower resources and soil moisture would influence hoverfly (Syrphidae) abundance and species richness in floristically-rich semi-natural and floristically-impoverished agricultural grassland communities in Wales (U.K.), and compared these to two Hymenoptera genera, Bombus and Lasioglossum. Interactions between environmental variables were tested using generalised linear modelling, and hoverfly community composition examined using canonical correspondence analysis.

3. There was no difference in hoverfly abundance, species richness, or bee abundance, between grassland types. There was a positive association between hoverfly abundance, species richness and flower abundance in unimproved grasslands. However, this was not evident in agriculturally improved grassland, possibly reflecting intrinsically low flower resource in these habitats, or the presence of plant species with low or relatively inaccessible nectar resources. There was no association between soil moisture content and hoverfly abundance or species richness.

4. Hoverfly community composition was influenced by agricultural improvement and the amount of flower resource. Hoverfly species with semiaquatic larvae were associated with both semi-natural and agricultural wet grasslands, possibly because of localised larval habitat. Despite the absence of differences in hoverfly abundance and species-richness, distinct hoverfly communities are associated with marshy grasslands, agriculturally improved marshy grasslands and unimproved dry grasslands, but not with improved dry grasslands.

5. Grassland plant community cannot be used as a proxy for pollinator community. Management of grasslands should aim to maximise the pollinator feeding resource, as well as maintain plant communities. Retaining waterlogged ground may enhance the number of hoverflies with semi-aquatic larvae. 


\section{Introduction}

Pollination by insects is a key ecosystem service for both agriculture and natural systems (Klein et al. 2007; Vanbergen et al. 2013; Gill et al. 2016). However, there is considerable concern about the declines in pollination services worldwide, caused by agricultural intensification, habitat degradation, the spread of diseases and parasites, and climate change (Biesmeijer et al. 2006; Potts et al. 2010; Goulson, Nicholls \& Botías 2015). In response to these concerns, a number of international, national and regional initiatives have been proposed to address declines in pollinator populations (Welsh Government 2013; DEFRA 2014; IPBES 2016). A key part of these initiatives is the increasing understanding of the significant role of wild insect species in providing pollination services, both within agricultural and semi-natural habitats (Garibaldi et al. 2013; Rader et al. 2015). There is an increasing body of research on how wild pollinators respond to agricultural management (Connelly, Poveda \& Loeb 2015; Lüscher et al. 2016), and what management methods could be employed to restore pollinator populations (Bruppacher et al. 2016; Hardman et al. 2016; Kovács-Hostyánszki et al. 2017). However, there are still gaps in our understanding of how pollinator populations respond to grassland communities and their management (Mayer et al. 2011; Dicks et al. 2013).

Amongst the Diptera, hoverflies (Syrphidae) are a significant group of pollinators (Rotheray \& Gilbert 2011). They can be effective pollinators of agricultural crops (Jauker \& Wolters 2008; Prodorutti \& Frilli 2008; Moisan-Deserres et al. 2014) and wild plant species (Forup et al. 2008; Brown \& McNeil 2009; Ollerton, Winfree \& Tarrant 2011). Individual hoverflies may not be as effective pollinators as bees, although this is compensated to some degree by population numbers (Jauker et al. 2012), and in some cases, the pollination service they provide can be complementary to that of bees (Ellis $e t$ al. 2017) . As adults they rely on nectar for carbohydrate, and pollen, which is a source of carbohydrate and lipids as well as protein for egg formation (Rotheray \& Gilbert 2011). There are 282 species of Syrphidae in Britain (Chandler, 2017), compared to 27 Bombus species and 247 other bee species (Falk \& Lewington 2015). Although hoverfly 
communities are known to be more species-rich on organic farms (Power, Jackson \& Stout 2016), relatively little is known of how hoverfly communities respond to some forms of agricultural intensification (Schweiger et al. 2007).

Semi-natural grasslands are amongst the most threatened habitats in Europe, because they are readily subject to agricultural intensification, which substantially reduces plant diversity (Van Dijk 1991; Habel et al. 2013) and their associated invertebrate communities (Hudewenz et al. 2012). In Great Britain, sites statutorily protected for their biodiversity (Sites of Special Scientific Interest) are selected and monitored primarily for their plant communities (Radcliffe 1989), with the assumption that such habitats will deliver wider ecosystem services such as pollination (Ricketts et al. 2008; Garibaldi et al. 2011; Eastwood et al. 2016). Pollinator guilds might be expected to be more numerous in sites where the plant species diversity offers a more varied, abundant and consistent food resource (Ebeling, Klein \& Tscharntke 2011). Understanding how invertebrate populations, including hoverflies, respond to agricultural intensification in grasslands is essential in formulating strategies to support ecosystem services such as pollination in agricultural landscapes (Weiner et al. 2011; Rzanny \& Voigt 2012) .

The over-arching aim of this study was to investigate which grassland habitats and management regimes might maximise hoverfly abundance and species-richness, and to compare this with the response of two bee genera, Bombus and Lasioglossum. Since hoverflies have specific larval habitat requirements and feeding biology, they might be expected to respond differently than bees to grassland community. We used pan-trapping to sample hoverfly and bee communities in grasslands in west Wales, UK, to answer the following questions:

1. How do hoverfly communities respond to both changes in grassland community as a consequence of agricultural intensification, and differences in plant community caused by variation in soil moisture. How does this response compare to two bee genera, Bombus and Lasioglossum? Since plant community richness has been shown to affect a number of invertebrate taxa (Schaffers et al. 2008), we would predict that pollinator communities will be more abundant and species-rich in grasslands with greater plant diversity.

2. How are hoverfly abundance and species-richness influenced by flower resource and soil moisture, and do these factors operate in a similar manner with 
Lasioglossum and Bombus? Hoverflies have distinctive mouthparts compared to bees that influence which flower morphologies are accessible for feeding. We predicted that this would lead to differing responses to flower resource.

3. How are hoverfly communities in different grasslands structured, and how do environmental factors influence this? We predicted that the diversity of hoverfly larval habitats and feeding biology would influence the species assemblages in different habitats.

\section{Materials and Methods}

Site Selection

Site selection was based on National Vegetation Classification (NVC) community (Rodwell et al. 1991; Rodwell et al. 1992). Twenty grasslands in west Wales were selected for sampling between June 2011 and September 2011 (figure 1, see also Appendix 1). These consisted of five each of two conservation grasslands (NVC communities MG5 and M24) and two agricultural grasslands (NVC communities MG6 and MG10):

- MG5 Cynosurus cristatus - Centaurea nigra grassland (hereafter 'dry grassland', DG). A dicotyledon-rich mesotrophic community frequently found in conservation grasslands in Britain, though rare in the wider agricultural landscape. Grasslands of this type are grazed or used for hay.

- M24 Molinia caerulea - Cirsium dissectum fen-meadow ('marshy grassland', MG). A species-rich community found on moist peaty mineral soils in southern Britain. A relatively rare community, much reduced by agricultural improvement. Such grasslands are usually managed with grazing by cattle or horses.

- MG6 Lolium perenne - Cynosurus cristatus grassland ('improved dry grassland', IDG). A grass-dominated community that is the major permanent agricultural pasture in lowland Britain. These grasslands may be grazed by cattle, sheep or horses, or cut for silage/hay.

- MG10 Juncus effusus - Holcus lanatus rush - pasture ('improved marshy grassland', IMG). A grass and rush dominated community developing on permanently moist agriculturally improved grasslands. Grasslands of this type are used for grazing cattle, sheep or horses. 
Dry grasslands and marshy grasslands were initially selected using the Countryside Council for Wales Phase II grassland survey (Stevens \& Mockridge 2004), which describes grasslands of high conservation value, whilst improved dry and marshy grasslands were identified from aerial photographs and by approaching sympathetic landowners. Grasslands were then checked to ensure that no other habitats, such as species-rich grasslands, woodland, or suburban gardens were within $400 \mathrm{~m}$ of the field boundary, which might provide an alternative source of pollinating insects to the grassland in the study. The value of $400 \mathrm{~m}$ was selected as the distance at which hoverflies have been observed to forage between patches of flowers (Rader et al. 2011). For dry grasslands and marshy grasslands, whilst it was acceptable to have grassland of the same plant community within $400 \mathrm{~m}$, sites with grasslands of a different community (e.g. a marshy grassland with an adjacent dry grassland) were rejected. All grasslands were evaluated, and only those passing these criteria were used to produce the final sample sites used in this study. 


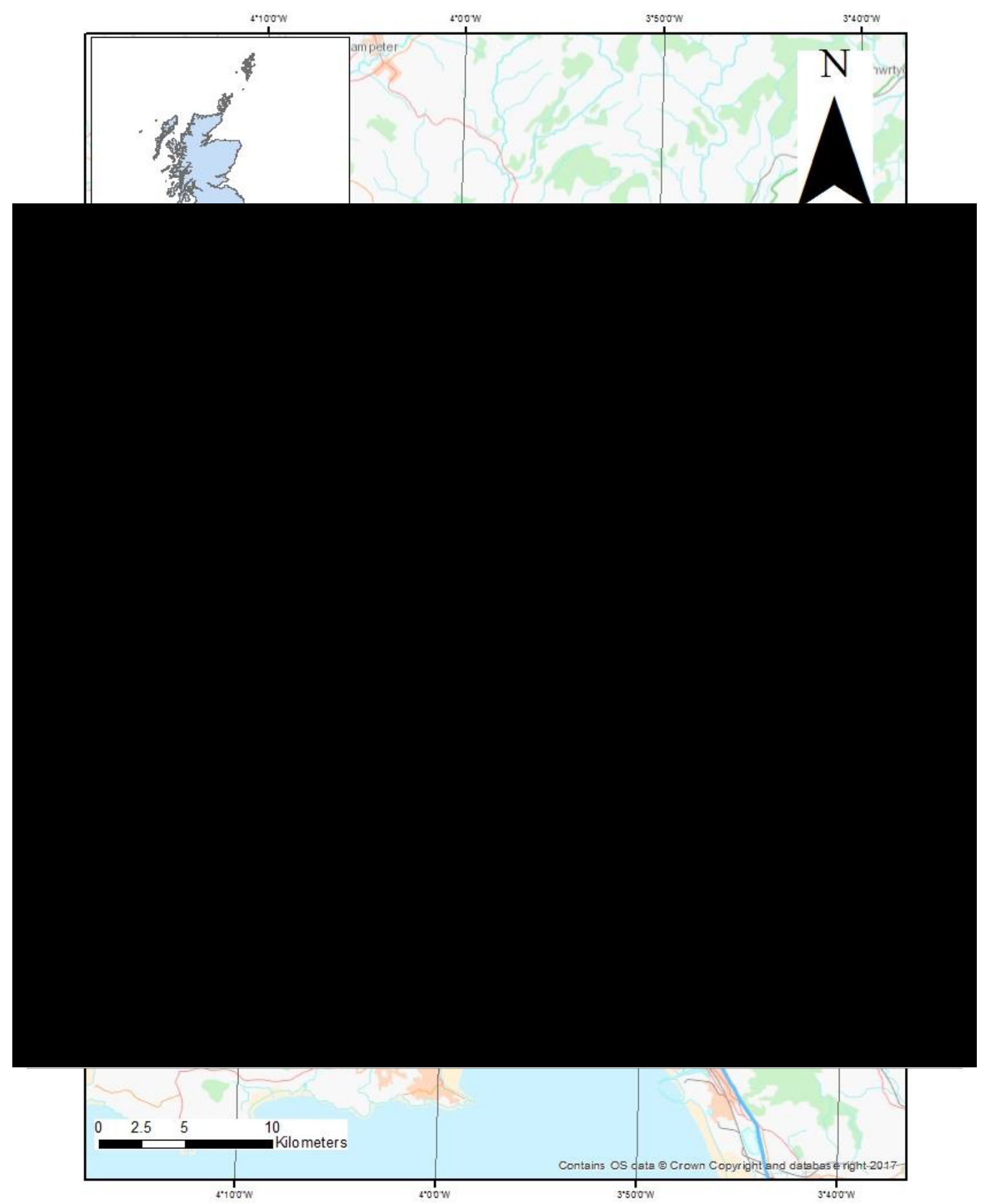

Figure 8. Sample Site Locations in South Wales, UK. (DG = dry grassland, IMG = Improved dry grasslands, MG = marshy grasslands, IMG = improved marshy grasslands) 
Sites ranged in size from 0.4ha (site MG1) to 6.9 ha (site IDG3) (see Appendix 1), and were classified using existing survey information (Stevens \& Mockridge 2004), or by recording three standard NVC $2 \times 2$ m quadrats in order to assign the grasslands to an appropriate community (Rodwell et al. 1992). Plant species diversity for each grassland site derived from these samples is shown in table 1. All of the grasslands studied were under grazing management, using combinations of cattle, horses and sheep, but grazing was not under experimental control.

\section{Insect sampling}

Insect sampling occurred in 2011 using pan traps. These consisted of plastic bowls (340 $\mathrm{mm}$ diameter and $128 \mathrm{~mm}$ depth), supplied by the manufacturer in three colours: white, blue and yellow (Laubertie, Wratten \& Sedcole 2006). Each sample site consisted of a group of nine pan traps at a single location, three of each colour, on a metal stand that positioned the bottom of each trap at the height of the surrounding vegetation. They were surrounded by a three strand barbed wire fence, to protect them from grazing animals, which would not impede insect movement (Wratten et al. 2003). Sample sites were at least $20 \mathrm{~m}$ from the nearest hedgerow to reduce the effect of hedgerow flowers attracting insects. The distance $20 \mathrm{~m}$ was selected because it was the maximum distance that a sample location could be placed from a hedgerow on the smallest sample site.

Sites were divided up into two equal groups to make fieldwork practical, with each group having a mix of grassland types. These two groups were sampled in alternate weeks (see Appendix 1). Each pan trap was filled with water to a depth of approximately $10 \mathrm{~cm}$, to which approximately $0.25 \mathrm{ml}$ of detergent and approximately $50 \mathrm{ml}$ of ethylene glycol was added (Wheater \& Cook 2003). They were then left for four days, and emptied within +/- one hour of the time they had originally been set. Insects were sieved from the water (sieve mesh size $2 \mathrm{~mm}^{2}$ ) and placed in bottles of $70 \%$ ethanol for identification. Pan traps were then covered or emptied for ten days, before the next sample interval. We sampled each site six times at 14 day intervals, between 17 June and 2 September 2011. Samples from each sample interval at a site were pooled for further analysis. 
Insect samples were identified morphologically under a light microscope (x20 - x40). Hoverflies were identified to species level using Stubbs and Falk (2002a), bumblebees (Bombus spp) identified to species using Benton (2009), and honeybees Apis mellifera Linnaeus identified to species and solitary bees identified to genus using BWARS (2011).

\section{Flower Resource Recording}

The available flower resource (floral units) at each site was also measured. A $50 \mathrm{~m}$ x 50 $\mathrm{m}$ plot (or equivalent area, to allow for field shape) was set out in the centre of each sample site. Thirty random sample locations were located within the plot. At each sample location, a $1 \mathrm{~m} \mathrm{x} 1 \mathrm{~m}$ quadrat was placed, and the number of floral units of each forb species (herbaceous flowering plants, excluding grasses, sedges, and rushes) in the quadrat was recorded (Rose 2006).

All flowers were counted on the plants within each sample location. For the Apiaceae, a single inflorescence was regarded as a floral unit. For Narthecium ossifragum L., Rhinanthus minor L., Calluna vulgaris L. and Orchidaceae species, a single flowering spike was regarded as a floral unit. Individual inflorescence heads of Trifolium species were also treated as a single floral unit. These measurements are similar to the 'blossom units' of Dicks et al. (2002). Floral unit density measurements were recorded twice, between June 1 and July 152012 and July 16 and August 31 2012, and the mean of the count of floral units between the two sampling periods was calculated to give a 'mean flower unit score' for each site. The mean number of plant species producing flowers between the two time period was also calculated to give a 'mean flowering species' score (table 1). For full details of plant species recorded flowering, see Appendix 2.

\section{Environmental Variables}

The Ellenberg values for $\mathrm{F}$ (moisture), $\mathrm{R}$ (reaction, or soil $\mathrm{pH}$ ) and $\mathrm{N}$ (nitrogen), were collated for all grassland higher plant species recorded in NVC quadrats at each site (Hill et al. 1999). The mean of these values was then calculated, to give a single value of $F, R$ and $\mathrm{N}$ for each site (table 1). Altitude data for each site was obtained from 1:25000 maps, and site areas calculated using MapInfo @Pitney Bowes Inc. Other environmental 
variables, such as rainfall or temperature, were not included as the sites were located relatively close together (figure 1).

\section{Statistical Analysis}

Data from all pan traps were combined to give one result for each sample site, as the close proximity of the traps meant that the samples were not independent.

We calculated the number of hoverfly individuals (abundance), hoverfly species (species richness), and the hoverfly Shannon Diversity Score H' for each site (table 1). Hoverflies of the genus Sphaerophoria, which can only be identified to species in males, were grouped as one category 'Sphaerophoria spp'. For the Bombus species, 430 individuals (99\%) were identified to six common species (B. hortorum L., B. lapidarius L., B. lucorum L., B. pratorum L., B. pascuorum Scopoli and B. terrestris L.). With so little species diversity, and the potential presence of the cryptic species B. cryptarum (Fabricius) and B. magnus (Vogt), all Bombus species were pooled at each site, to give a single figure for Bombus abundance. For solitary bees, 69\% $(\mathrm{n}=299)$ of individuals belonged to one genus, Lasioglossum, with no other genus sufficiently widespread and numerous to justify further analysis. Honeybee abundance was not analysed because of the possible bias in numbers that could be caused by any nearby domestic honeybee colonies.

Since data for abundance, species-richness and diversity indices did not conform to a normal distribution, differences between the four grassland communities were assessed using Kruskall-Wallis $\mathrm{H}$ tests. This test was also used to investigate possible differences in altitude and site area between grassland types (see Appendix 3). All analysis was undertaken in $\mathrm{IBM}^{\odot}$ SPSS $^{\odot}$ Statistics Version 22.

To investigate the influence of feeding resource availability on hoverfly abundance and species richness, generalised linear modelling using a Poisson distribution and a log link function was undertaken. We accounted for overdispersion by employing a quasipoisson model where appropriate. Poisson models were assessed using $\mathrm{X}^{2}$ tests, quasipoisson using F tests. The response variable comprised count data (abundance or richness), with 
natural logarithm-transformed floral unit scores (transformed since maximum floral unit scores were substantially lower in agriculturally improved land), soil moisture (marshy vs. dry), and level of improvement (unimproved vs. improved) as explanatory variables, which were included as main effects as well as fully interacting. Analysis was undertaken using R 3.1.4 (R Core Team 2014).

Hoverfly community structure was visualised using canonical correspondence analysis (CCA), using Environmental Community Analysis Version 2.1, 2007, Pisces

Conservation Ltd. Lymington, UK (www.pisces-conservation.com). Mean site Ellenberg values for plant species from each sample site were used as explanatory variables in the model (Cajo 1986), together with mean floral unit score and mean flowering species. Weighted variables were used to generate the ordination figures. A Monte Carlo randomization test, using 1000 trials, was undertaken to test the significance of the variability explained by each ordination axis.

\section{Results}

In total, 1171 hoverflies of 42 species, 450 Bombus bees of 10 species, and 299 solitary bees in 12 genera were recorded (table 1, and Appendix 4). 
Table 1 Hoverfly abundance, hoverfly species richness, hoverfly Shannon H diversity, Bombus abundance, Lasio species richness, mean number of flowering species, mean flower score, and mean Ellenberg values for four gr pan traps in 2011

\begin{tabular}{|c|c|c|c|c|c|c|c|}
\hline $\begin{array}{l}\text { Site } \\
\text { Name }\end{array}$ & $\begin{array}{l}\text { Hoverfly } \\
\text { Abundance }\end{array}$ & $\begin{array}{l}\text { Hoverfly species } \\
\text { richness }\end{array}$ & $\begin{array}{l}\text { Hoverfly } \\
\text { Shannon H }\end{array}$ & $\begin{array}{l}\text { Lasioglossum } \\
\text { abundance }\end{array}$ & $\begin{array}{l}\text { Bombus } \\
\text { abundance }\end{array}$ & $\begin{array}{l}\text { Site Plant } \\
\text { spp richness }\end{array}$ & $\begin{array}{l}\text { Mean } \\
\text { Flowering } \\
\text { Species }\end{array}$ \\
\hline DG1 & 212 & 12 & 1.821 & 31 & 69 & 29 & 9.5 \\
\hline DG2 & 7 & 5 & 1.550 & 1 & 17 & 23 & 2 \\
\hline DG3 & 15 & 9 & 2.026 & 4 & 34 & 27 & 3.5 \\
\hline DG4 & 6 & 4 & 1.523 & 0 & 9 & 20 & 5.5 \\
\hline DG5 & 25 & 11 & 1.804 & 11 & 17 & 30 & 9.5 \\
\hline IDG1 & 53 & 14 & 1.632 & 36 & 15 & 14 & 1.5 \\
\hline IDG2 & 9 & 7 & 1.831 & 24 & 7 & 15 & 2 \\
\hline IDG3 & 30 & 11 & 2.280 & 9 & 11 & 10 & 2.5 \\
\hline IDG4 & 25 & 6 & 1.167 & 5 & 17 & 9 & 2 \\
\hline IDG5 & 11 & 7 & 1.768 & 14 & 26 & 8 & 1.5 \\
\hline IMG1 & 59 & 15 & 2.220 & 4 & 21 & 18 & 5 \\
\hline IMG2 & 43 & 14 & 2.240 & 7 & 20 & 17 & 6.5 \\
\hline IMG3 & 50 & 14 & 2.401 & 6 & 9 & 12 & 3.5 \\
\hline IMG4 & 66 & 13 & 1.941 & 7 & 15 & 14 & 4.5 \\
\hline IMG5 & 18 & 8 & 1.769 & 1 & 12 & 11 & 5 \\
\hline MG1 & 64 & 11 & 1.247 & 3 & 16 & 27 & 4.5 \\
\hline MG2 & 37 & 11 & 1.986 & 6 & 29 & 30 & 4.5 \\
\hline MG3 & 192 & 19 & 2.189 & 31 & 58 & 21 & 8 \\
\hline MG4 & 179 & 22 & 2.166 & 8 & 34 & 24 & 8.5 \\
\hline MG5 & 48 & 15 & 2.237 & 0 & 14 & 21 & 5 \\
\hline
\end{tabular}


Amongst hoverflies, Eristalis species were the most frequent $(45 \% \mathrm{n}=520)$ across all sites, with Helophilus pendulus L. $(24 \% \mathrm{n}=320)$ and Rhingia campestris Meigen $(9 \% \mathrm{n}$ =106) also commonly recorded.

There were no significant differences in altitude or site area between grassland types using a Kruskall-Wallis test, and therefore these factors were not used in subsequent modelling (Altitude: $\mathrm{H}_{(3)}=6.56 \mathrm{p}>0.05$, Area $\mathrm{H}_{(3)}=2.78 \mathrm{p}>0.05$ ).

A summary of the floral unit scores are shown in figure 2 and table 1 (with full results in Appendix 2). A total of 45 species were recorded flowering across all sites. Amongst the most widespread flowering taxa were Ranunculus spp, Potentilla erecta, and species of Apiaceae (Heracleum sphondylium and Carum verticillatum). 

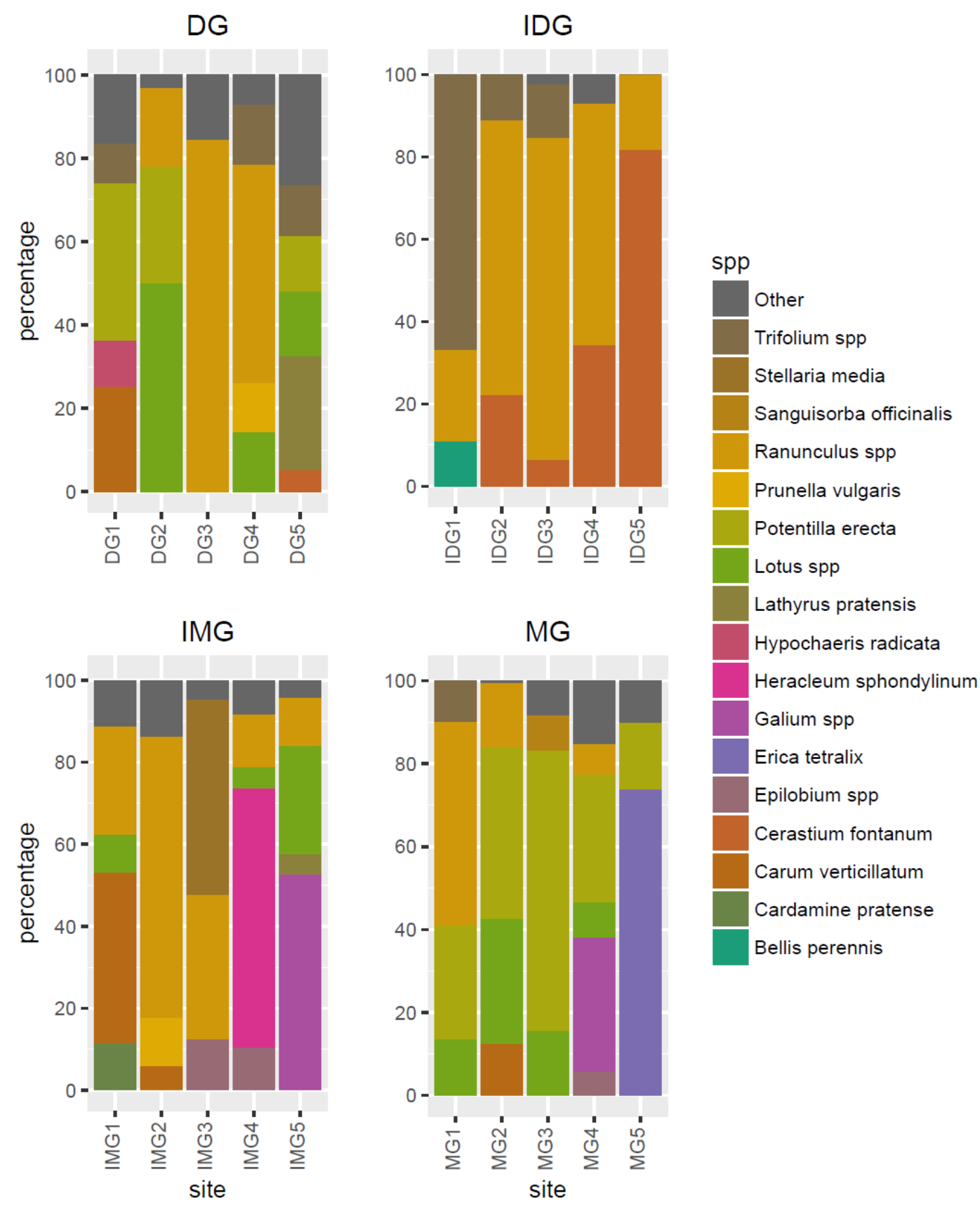

Figure 9 Percentage of flower units from plant species contributing more than $5 \%$ of total flower unit score in four grassland communities (DG = 'Dry Grassland', IDG = 'Improved Dry Grassland', IMG = 'Improved Marshy Grassland', MG = 'Marshy Grassland'). 
Are there differences in hoverfly diversity and abundance, and bee abundance, between grassland types?

No significant differences were observed in hoverfly abundance, H Diversity, Bombus abundance and Lasioglossum abundance between grassland community type, using a Kruskall-Wallis test (see Appendix 3). There was an initial significant difference in hoverfly species-richness between grassland communities $(H=8.225, \mathrm{p}=0.042)$. However, subsequent analysis using a Bonferroni correction for multiple comparisons showed no significant pairwise comparisons (see Appendix 3).

Are hoverfly abundance and species-richness, and bee abundance, influenced by flower resource and soil moisture?

\section{$\underline{\text { Treatment of 'mean floral unit score' and 'mean flowering species' }}$}

We compared 'mean floral unit score' and 'mean flowering species' as measures of flower resource. Both variables were positively correlated (Spearman's $\rho=0.797, \mathrm{p}<$ 0.001). Therefore, we did not include both as explanatory variables in the same statistical models. Instead, we compared the full model (three-way interaction: flower score $\mathrm{x}$ improvement $\mathrm{x}$ moisture) for each measure of flowering, using AIC. We found that for all insect pollinator taxa, 'mean floral unit score' was a better predictor than 'mean flower species' (Hoverfly abundance, $\triangle \mathrm{AIC}=7.24$. Hoverfly species richness $\triangle \mathrm{AIC}=9.27$. Lasioglossum abundance, $\Delta \mathrm{AIC}=10.15$. Bombus abundance, $\Delta \mathrm{AIC}=2.83$ ).

\section{$\underline{\text { Insect pollinator abundance and species richness }}$}

The effects of mean floral unit score on hoverfly abundance, hoverfly species richness, Lasioglossum bee abundance, and Bombus bee abundance were quantified (Figure 3). In each case, the full model incorporating the three-way interaction between floral unit score, agricultural improvement, and soil moisture was assessed by stepwise deletion using $\mathrm{F}$ tests (Table 2). In all cases, the best fitting model showed a statistically significant increase in pollinators with increasing mean floral unit score in unimproved 
grassland (Table 3). However, this was not found in agriculturally improved grassland (Table 3). Hoverfly abundance, hoverfly species richness, and Bombus bee abundance were not significantly affected by mean floral unit score, whereas Lasioglossum bee species abundance significantly decreased with increasing mean floral unit score (Table 3). Other interaction terms were not statistically significant. Since it was not a component of statistically significant interaction terms, soil moisture was assessed as a main effect (Table 2). This was only found to have a statistically significant effect on hoverfly species richness, with more species found in marshy ground than dry (Estimate $=0.542, \mathrm{SE}=$ $\left.0.181, \mathrm{~F}_{1,15}=2.99, \mathrm{p}=0.009\right)$. 
Table 2 Analysis of Variance explaining insect pollinator abundance and species richness. FS = "mean Floral unit Score", I = "soil Moisture". Terms are presented in the order they were assessed in stepwise deletion of the full model, incorporating order terms. Statistically significant terms $(p<0.05)$ are shown in bold

\begin{tabular}{|c|c|c|c|}
\hline & \multicolumn{2}{|c|}{ Hoverfly abundance } & Hoverfly sp \\
\hline & $\mathrm{F}$ & $\mathrm{p}$ & $\mathrm{F}$ \\
\hline $\mathrm{FS} \times \mathrm{I} \times \mathrm{M}$ & 0.761 & 0.400 & 0.095 \\
\hline $\mathrm{I} \times \mathrm{M}$ & 0.292 & 0.598 & 0.047 \\
\hline $\mathrm{FS} \times \mathrm{M}$ & 4.124 & 0.062 & 1.495 \\
\hline $\mathrm{M}$ & 0.815 & 0.381 & 9.277 \\
\hline \multirow[t]{3}{*}{ FS $\times 1$} & 5.960 & 0.027 & 10.75 \\
\hline & \multicolumn{2}{|c|}{ Lasioglossum abundance } & Bombus \\
\hline & $\mathrm{F}$ & $\mathrm{p}$ & $\mathrm{F}$ \\
\hline $\mathrm{FS} \times \mathrm{I} \times \mathrm{M}$ & 0.569 & 0.465 & 0.595 \\
\hline $\mathrm{I} \times \mathrm{M}$ & 2.185 & 0.163 & 0.169 \\
\hline $\mathrm{FS} \times \mathrm{M}$ & 0.691 & 0.420 & 0.330 \\
\hline $\mathrm{M}$ & 1.821 & 0.197 & 0.900 \\
\hline FS $\times 1$ & 76.84 & $<0.001$ & 6.868 \\
\hline
\end{tabular}


Table 3 Parameter estimates from log-linear regression of insect pollinator abundance and species richness on mean flora and unimproved grassland. Statistically significant terms are shown in bold

\begin{tabular}{|c|c|c|}
\hline Response to floral unit score in agriculturally improved land & Estimate & SE \\
\hline Hoverfly abundance & 0.111 & 0.225 \\
\hline Hoverfly species richness & -0.160 & 0.102 \\
\hline Lasioglossum abundance & -0.686 & 0.133 \\
\hline Bombus abundance & -0.016 & 0.136 \\
\hline Response to floral score in agriculturally unimproved land & & \\
\hline & & \\
\hline Hoverfly abundance & Estimate & $\mathbf{0 . 2 4 0}$ \\
\hline Hoverfly species richness & $\mathbf{0 . 9 0 1}$ & $\mathbf{0 . 1 0 5}$ \\
\hline Lasioglossum abundance & $\mathbf{0 . 2 7 4}$ & $\mathbf{0 . 2 2 3}$ \\
\hline Bombus abundance & $\mathbf{1 . 2 5 3}$ & $\mathbf{0 . 1 3 4}$ \\
\hline & & \\
\hline
\end{tabular}


There was a substantial degree of multicollinearity between $\mathrm{R}$ (reaction) and $\mathrm{N}$ (nitrogen) (Reaction: $\mathrm{R}^{2}=0.906, \mathrm{VIF}=10.65$; Nitrogen: $\mathrm{R}^{2}=0.900 \mathrm{VIF}=9.96$ ). Since this study was concerned with the impact of agricultural improvement, the variable $\mathrm{N}$ was retained in the analysis and $\mathrm{R}$ was removed.

A Monte Carlo significance test with 1000 runs showed that axis 1 (broadly defined by nitrogen, $\mathrm{N}$ and mean number of flowering species) was significant in explaining the variance of the data, whilst axis 2 was not significant (Axis 1 Eigen values $=0.269$, mean $=0.168$, maximum $=0.303$, minimum $=0.076, p=0.015 ;$ Axis 2 Eigen values $=0.093$, mean $=0.095$, maximum $=0.162$, minimum $=0.047, \mathrm{p}=0.510$ ).

The marshy grassland and improved marshy grassland showed within-group clustering on axis 1 , suggesting a consistent community of hoverflies (figure 4). The dry grassland sites were also clustered on axis 1 . The improved dry grassland hoverfly communities showed relatively low clustering on axis 1, suggesting there is no consistent hoverfly assemblage associated with this habitat. 


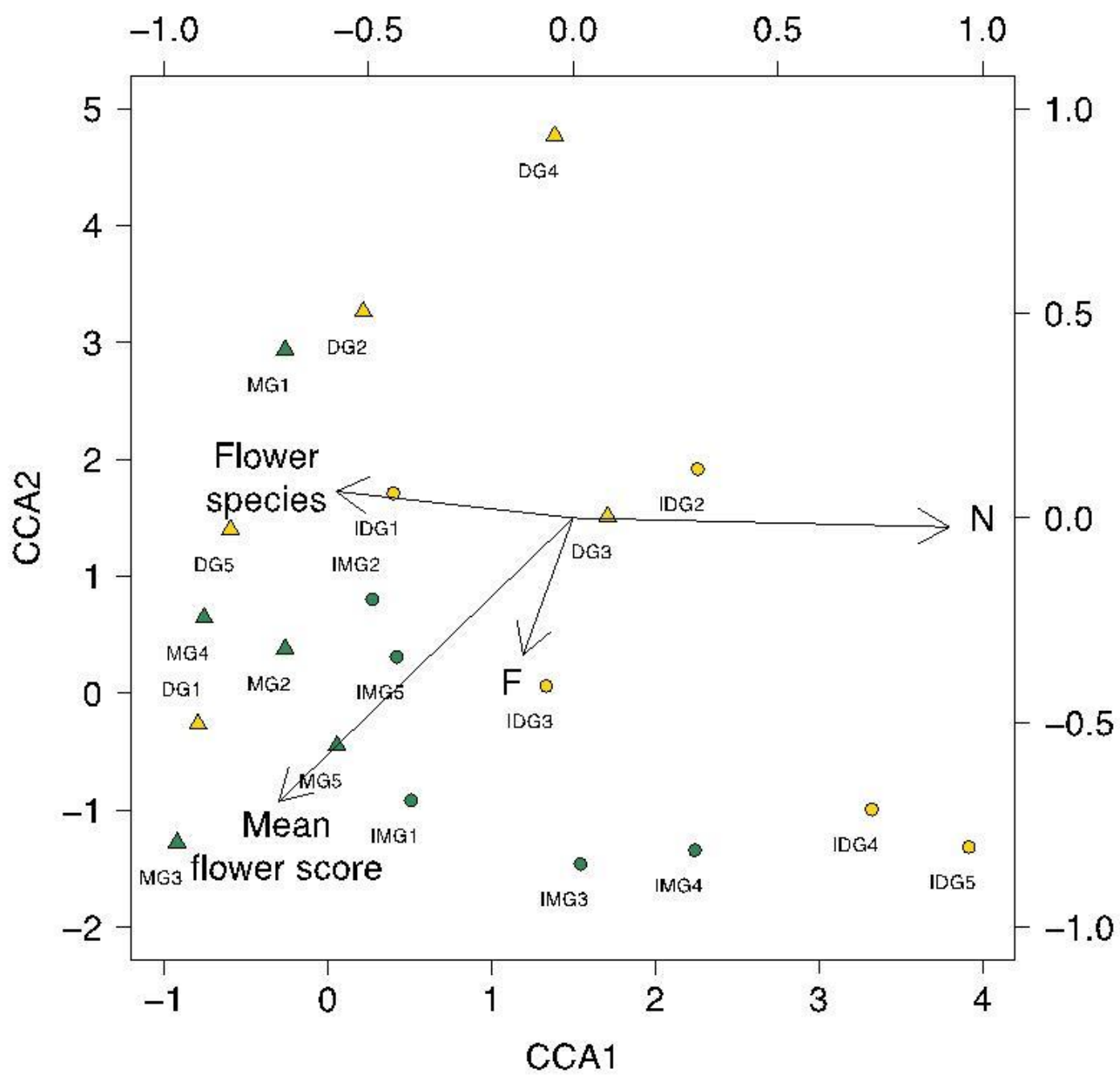

Figure 3 Canonical Correspondence Analysis biplot of hoverfly communities assessed using pan traps during 2011 at four grassland habitats, using mean flower score, mean number of flowering species ('Flower species'), and mean plant Ellenberg values for F (moisture) and N (nitrogen) as environmental variables. MG (marshy grasslands) - green triangles; IMG (improved marshy grasslands) - green circles; DG (dry grasslands) yellow triangles; IDG (improved dry grasslands) - yellow circles.

Common hoverfly species with semi-aquatic larvae, (Eristalis species, Helophilus pendulus and Sericomyia silentis Harris) or species commonly occurring in wet pastures (Platycheirus granditarsa Forster) were associated with marshy grassland (figure 5), having low values on axis 1 . By contrast, Rhingia campestris, whose larvae use cow 
dung, and Episyrphus balteatus De Greer, Eupeodes corollae Fabricius, Sphaerophoria species, Melanostoma mellinum L. and Platycheirus clypeatus Meigen, all of which have aphidophagous larvae, have higher values on axis 1, suggesting a higher association with improved pastures.

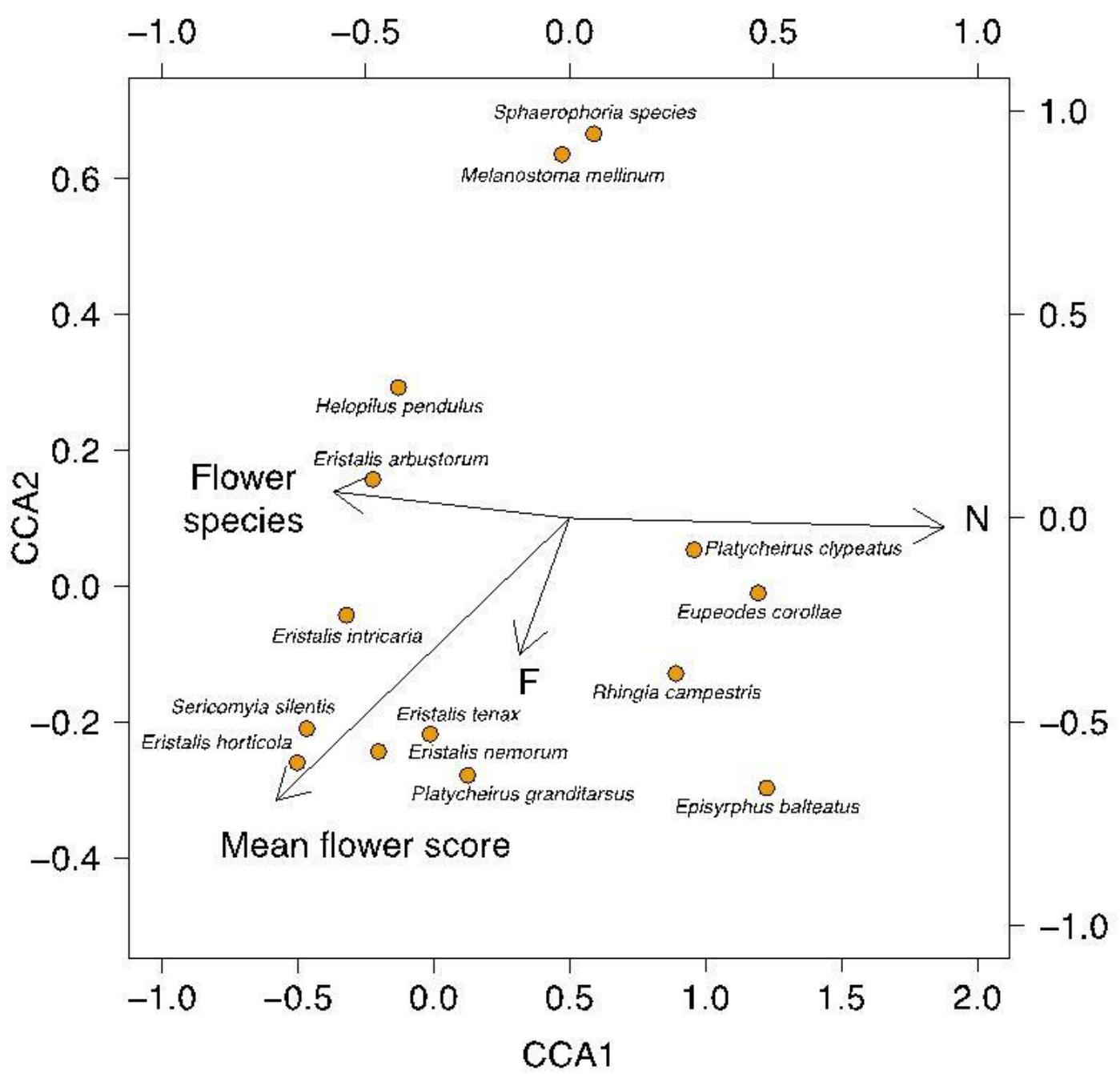

Figure 4 Canonical Correspondence Analysis biplot of hoverfly species assessed using pan traps during 2011 at four grassland habitats, using mean flower score, mean number of flowering species ('Flower species'), and mean plant Ellenberg values for F (moisture) and $\mathrm{N}$ (nitrogen) as environmental variables. For clarity, species with an abundance less than $1 \%$ of the total for all sites have been omitted. 


\section{Discussion}

This study shows that hoverflies and bees are responding to both the habitat and its flower resource. Our prediction was that the grassland community, as defined by plant species richness, would have a key influence on the abundance and species-richness of their hoverfly communities. However, it is the flower abundance, as well as the soil moisture associated with different grassland communities, which is critical to determining the abundance and species composition of hoverfly communities.

Hoverflies, bees and grassland community type

There were no significant differences in hoverfly abundance, species richness, or bee abundance between the four grassland communities ('dry grassland' DG, 'improved dry grassland' IDG, 'improved marshy grassland' IMG and 'marshy grassland' MG). This was unexpected, given the evidence that diverse plant communities support equally diverse invertebrate communities (Schaffers et al. 2008; Senapathi et al. 2015). Diverse grasslands offer more consistent foraging resources to all pollinator guilds, which can enhance the stability of pollination services (Ockinger \& Smith 2007; Garibaldi et al. 2011). However, the results of this study suggest that plant community alone cannot be used as a surrogate for the associated pollinator assemblage.

\section{Hoverflies, flower resource and soil moisture}

Increasing the flower resource, and therefore the feeding opportunities for adult hoverflies, increased both hoverfly abundance and species-richness. This effect was only detected on unimproved grasslands, and the absence of this effect on improved grasslands may be a result of three factors. Firstly, improved grasslands, by definition, have a lower forb and higher graminoid cover (Rodwell et al. 1992), and therefore will have low flower scores overall. Secondly, the plant species that were flowering at improved sites included species such as Cerastium fontanum, Stellaria media, and Galium species (e.g. sites IMG3, IMG5 and IDG5, figure 1 and 2). These species produce a large number of 
very small flowers, with relatively low nectar production (Baude et al. 2016). Such nectar splitting can make food collection more energetically demanding (Carvalheiro et al. 2014). Thirdly, other species that form a significant part of the limited flower resource at improved sites include Trifolium species and two genera of Fabaceae, Lathyrus and Lotus (e.g. IDG1, IMG3 and IMG5, figure 1 and 2). These plants produce zygomorphic flowers that are relatively inaccessible to the mouthparts of many hoverfly species (Gilbert 1981; Branquart \& Hemptinn 2000). Thus, not only is the feeding resource for hoverflies reduced on improved grasslands, but many of the flowers that are present are of low quality as a food resource. A similar effect of increasing flower resource was also found for Lasioglossum and Bombus bees, which were both more abundant at sites with higher flower scores. However, abundance of Lasioglossum fell with increasing flower score on improved dry grasslands. This could represent competitive interaction by other pollinators (Biesmeijer et al. 1999; Dworschak \& Bluthgen 2010), the flower species and available nectar resource (as described for hoverflies above), or differences in foraging strategies (Gathmann \& Tscharntke 2002).

Flower resource is dependent upon both the availability of suitable plant species, and a suitable management. Intensive management can result in a more uniform sward with few flowers (Vickery et al. 2001). This can make a species-rich grassland little different, in terms of the available flowers for pollinator foraging, from an agriculturally improved grassland (Power \& Stout 2011). This may explain the lack of significant differences in hoverfly abundance and species-richness, and bee abundance, between the different grassland communities. The plant species composition of a grassland community itself is not a reliable predictor of pollinator abundance and species-richness unless the management regime and consequent flower resource is also considered (Power \& Stout 2011; Feltham et al. 2015; Jönsson et al. 2015). Soil moisture level did not influence hoverfly abundance, species-richness or bee abundance.

\section{Hoverfly Community Structure and Grassland Type}

The results of the CCA showed that axis 1, broadly associated with environmental variable $\mathrm{N}$ and mean number of flowering species which are both a proxy for the degree of agricultural improvement (Habel et al. 2013), is a key factor in determining hoverfly 
community structure, demonstrating the importance of retaining agriculturally unimproved pastures as hoverfly habitat.

There appears to be a consistent community of hoverflies associated with both marshy grasslands and, to a lesser extent, improved marshy grasslands. Dry grassland sites also show some degree of clustering on axis 1 (figure 4). Hoverflies with semi-aquatic larvae (Eristalis species, Helophilus pendulus, and Sericomyia silentis), or species associated with damp pastures (Platycheirus granditarsus) (Stubbs \& Falk 2002a) were particularly associated with marshy and improved marshy grasslands (figure 5). This indicates that these grasslands may provide species which oviposit in waterlogged sites with localised egg-laying sites and suitable larval habitat, not reflected in the wider plant community. In contrast, the hoverfly assemblages in dry grasslands were more variable in species composition compared to marshy grasslands, and included species with carnivorous larval stages (Melanostoma mellinum, Eupeodes corollae Fabricius and Episyrphus balteatus De Geer). It is also noticeable that Rhingia campestris, a species whose larval habitat is cow dung, has a greater tolerance for relatively higher $\mathrm{N}$ values than many other species. This may reflect cattle husbandry in a range of grasslands, and the ability of $R$. campestris adults to feed on flowers inaccessible to many other hoverflies (Haslett 1989). Larval habitat has previously been noted as a factor structuring hoverfly community structure (Meyer, Jauker \& Steffan-Dewenter 2009; Mueller \& Dauber 2016). Given the diverse nature of hoverfly larval strategies and their potential agricultural importance, greater study of larval ecology is a subject for future research.

Improved dry grassland hoverfly communities showed relatively low clustering in their species assemblages on axis 1 (figure 4). The hoverfly species present appear to be a stochastic association of species, with no clear or repeatable pattern between sites. If hoverflies from more suitable habitats were dispersing into improved dry grasslands, it might be expected that the hoverfly community composition of improved dry grasslands might reflect more species-rich hoverfly communities, although probably at lower levels of abundance. That the hoverfly communities of these floristically impoverished habitats vary amongst each other, and have an unpredictable element, suggests that there is no consistent 'spill-over' into improved dry grasslands from more suitable, if distant, habitats. This indicates that, although the delivery of pollination services by hoverflies in 
agriculturally intensive systems is related to the amount of available habitat in the wider landscape (Power, Jackson \& Stout 2016), it cannot rely on dispersal from distant breeding sites.

Measuring floral unit abundance is relatively straightforward for land managers but, as shown by this study, has limitations if the accessibility of the nectar resource is not considered. Using nectar resource directly would be a more robust method, particularly as data on many common British agricultural species is now available (Baude et al. 2016). Unfortunately, the data does not include the umbellifer Carum verticillatum, a common plant in our study found in semi-natural and even some improved marshy grasslands in west Wales. However, integrating flower abundance and nectar resource is likely to improve the ability of models to predict hoverfly communities compared to flower unit data. Similarly, using pan traps is a simple and effective method of sampling pollinator populations (Carvell et al. 2016), but does have limitations. Unlike netting insects as they visit plants, there is no direct link between pan trap records and flower visitation (Popic, Davila \& Wardle 2013). Pan traps can also over-sample pollinators in resource-poor environments by 'sucking in' pollinators, and can under-sample in flowerrich sites where there are many competing stimuli (Hickman et al. 2001; Roulston, Smith \& Brewster 2007; Wilson, Griswold \& Messinger 2008). However, they do reduce the sampling bias associated with hand netting (Spafford \& Lortie 2013). Ideally, any site pollinator assessment should use a combination of trapping and net sweeping to collect data.

This study attempted to control for the influence of the landscape on pollinator populations by selecting sites that were relatively distant from other habitats from which pollinators might disperse. However, no such control can be perfect, and wider landscape has been demonstrated to have an impact on pollinator populations at specific sites (Ockinger et al. 2012; Ekroos, Rundlof \& Smith 2013; Power, Jackson \& Stout 2016). Therefore, the possibility that some of the differences in hoverfly communities in this study were the result of factors operating at a landscape scale cannot be discounted. 
This study provides a framework to assess the potential for a grassland to support a diverse hoverfly community. Grassland plant community has been long treated as a surrogate for invertebrate community richness e.g. with ground beetles (Yanahan \& Taylor 2014), and butterflies and grasshoppers (Koch et al. 2013). Plant communities have been frequently used as a method of selecting sites for nature conservation designations, both at a British and at European levels (Radcliffe 1989; Evans 2012; Mucina et al. 2016). This study suggests that a more diverse plant community has the potential to support a rich hoverfly fauna, but only if management meets other key requirements of their lifecycle, such as flower resource.

Flower resource is a function of both the plant community and the associated management regime. Whilst agricultural improvement can reduce the number of forb species directly, any factor that can reduce the numbers of flowers, even on floristically species-rich swards, can have a direct effect on flower resource availability, and therefore hoverfly abundance and species-richness. Grazing is one such a factor, and a response to grazing has been noted in a number of other invertebrate groups, including dung beetles, (Verdu et al. 2007), butterflies, and grasshoppers (Jerrentrup et al. 2014). Similar moderate grazing regimes have been shown to be beneficial for pollinator communities (Vanbergen et al. 2014) and specifically hoverflies (Hudewenz et al. 2012; Lazaro et al. 2016). This study confirms that a resource of flowers available for feeding hoverflies, and the lower intensity management regime that can help produce it, is a significant factor in driving hoverfly communities.

Dicks et al. (2015) attempted to evaluate how much suitable habitat is required to maintain viable populations of wild bees, in order to maintain a viable pollination ecosystem service. Our findings suggest that a similar calculation for hoverflies would have to take some account of larval habitat requirements, an effect that has been noted in relation to other insect providers of ecosystem services, such as parasitoid wasps (Gillespie, Gurr \& Wratten 2016). Hoverfly communities of marshy grasslands, whether agriculturally improved or not, can be distinctive from those found in drier grasslands (Carey, Williams \& Gormally 2017). In particular, our study has shown that hoverflies in the genera Eristalis, Sericomyia, and Helophilus, all appear to be particularly associated 
with wetter ground. Since these are relatively large, hairy bee and wasp mimics (Stubbs \& Falk 2002b), they may have significant potential as pollinators (Stavert et al. 2016).

Habitats that support hoverfly populations provide a pollination ecosystem service, by providing pollinators to crops on adjacent land (Garibaldi et al. 2011), facilitating additional functions that underpin other ecosystem services (Mace, Norris \& Fitter 2012), and maintaining the cultural services provided by the habitats themselves (Potts et al. 2016). To effectively conserve and enhance the pollination ecosystem service provided by hoverflies, management should retain remaining species-rich grassland communities (Ockinger \& Smith 2007; Lentini et al. 2012), and ensure they are under appropriate management that allows a sufficient flower resource for feeding. Grasslands that may have been subject to agricultural improvement can still be of some value to hoverflies if management becomes less intensive, allowing more forbs with accessible food resources to flower (Hudewenz et al. 2012; Orford et al. 2016). Finally, and critically, management for varied hoverfly communities must include the provision of larval habitat. For semiaquatic species, this can include either land that is periodically waterlogged or adjacent wetlands.

\section{Acknowledgements}

The authors are grateful to all landowners, in particular Nick and Kyra Somerfield, and Geoff and Sue Freeman. Students and staff from Swansea University helped with sample site construction. Ian Tew advised on sample identification. Professor Bill Kunin of Leeds University gave valuable guidance on experimental design. This study was supported by the Countryside Council for Wales (latterly Natural Resources Wales). The authors thank four anonymous reviewers for their constructive comments that significantly improved the final manuscript.

\section{Data Accessibility}

Data is available via the Dryad Digital Repository doi:10.5061/dryad.1rd15 


\section{References}

Baude, M., Kunin, W.E., Boatman, N.D., Conyers, S., Davies, N., Gillespie, M.A.K., Morton, R.D., Smart, S.M. \& Memmott, J. (2016) Historical nectar assessment reveals the fall and rise of floral resources in Britain. Nature, 530, 85-88.

Benton, T. (2009) Bumblebees. Collins, London.

Biesmeijer, J.C., Richter, J.A.P., Smeets, M.A.J.P. \& Sommeijer, M.J. (1999) Niche differentiation in nectar-collecting stingless bees: the influence of morphology, floral choice and interference competition. Ecological Entomology, 24, 380-388.

Biesmeijer, J.C., Roberts, S.P.M., Reemer, M., Ohlemuller, R., Edwards, M., Peeters, T., Schaffers, A.P., Potts, S.G., Kleukers, R., Thomas, C.D., Settele, J. \& Kunin, W.E. (2006) Parallel declines in pollinators and insect-pollinated plants in Britain and the Netherlands. Science, 313, 351-354.

Branquart, E. \& Hemptinn, J. (2000) Selectivity in the exploitation of floral resources by hoverflies (Diptera: Syrphinae). Ecography, 23, 732 - 742.

Brown, A.O. \& McNeil, J.N. (2009) Pollination ecology of the high latitude, dioecious cloudberry ( Rubus chamaemorus ; Rosaceae). American Journal of Botany, 96, 1096-1107.

Bruppacher, L., Pellet, J., Arlettaz, R. \& Humbert, J.-Y. (2016) Simple modifications of mowing regime promote butterflies in extensively managed meadows: Evidence from field-scale experiments. Biological Conservation, 196, 196202.

BWARS (2011) Bees in Britain Chapter Four: A key to the genera of British bees., pp. http://www.bwars.com/content/bees-britain.

Cajo, J.F.T.B. (1986) Canonical Correspondence Analysis: A New Eigenvector Technique for Multivariate Direct Gradient Analysis. Ecology, 67, 1167-1179.

Carey, J.G.J., Williams, C.D. \& Gormally, M.J. (2017) Spatiotemporal variation of Diptera changes how we evaluate High Nature Value (HNV) wet grasslands. Biodiversity and Conservation, 1-16.

Carvalheiro, L.G., Biesmeijer, J.C., Benadi, G., Fründ, J., Stang, M., Bartomeus, I., KaiserBunbury, C.N., Baude, M., Gomes, S.I.F., Merckx, V., Baldock, K.C.R., Bennett, 
A.T.D., Boada, R., Bommarco, R., Cartar, R., Chacoff, N., Dänhardt, J., Dicks, L.V., Dormann, C.F., Ekroos, J., Henson, K.S.E., Holzschuh, A., Junker, R.R., Lopezaraiza-Mikel, M., Memmott, J., Montero-Castaño, A., Nelson, I.L., Petanidou, T., Power, E.F., Rundlöf, M., Smith, H.G., Stout, J.C., Temitope, K., Tscharntke, T., Tscheulin, T., Vilà, M. \& Kunin, W.E. (2014) The potential for indirect effects between co-flowering plants via shared pollinators depends on resource abundance, accessibility and relatedness. Ecology Letters, 17, 1389-1399.

Carvell, C., Isaac, N.J.B., Jitlal, M., Peyton, J., Powney, G.D., Roy, D.B., Vanbergen, A.J., O’Connor, R.S., Jones, C.M., Kunin, W.E., Breeze, T.D., Garratt, M.P.D., Potts, S.G., Harvey, M., Ansine, J., Comont, R.F., Lee, P., Edwards, M., Roberts, S.P.M., Morris, R.K.A., Musgrove, A.J., Brereton, T., Hawes, C. \& Roy, H.E. (2016) Design and Testing of a National Pollinator and Pollination Monitoring Framework. Final summary report to the Department for Environment, Food and Rural Affairs (Defra), Scottish Government and Welsh Government: Project WC1101.

Chandler, P.J. (2017) An Update of the 1998 Checklist of Diptera of the British Isles (updated 16 January 2017).

http://www.dipteristsforum.org.uk/sgb_check_intro.php (accessed 12/07/2017)

Connelly, H., Poveda, K. \& Loeb, G. (2015) Landscape simplification decreases wild bee pollination services to strawberry. Agriculture, Ecosystems \& Environment, 211, 51-56.

DEFRA (2014) A consultation on the National Pollinator Strategy for bees and other pollinators in England.A consultation on the National Pollinator Strategy for bees and other pollinators in England. DEFRA, Bristol.

Dicks, L.V., Abrahams, A., Atkinson, J., Biesmeijer, J., Bourn, N., Brown, C., Brown, M.J.F., Carvell, C., Connolly, C., Cresswell, J.E., Croft, P., Darvill, B., De Zylva, P., Effingham, P., Fountain, M., Goggin, A., Harding, D., Harding, A., Hartfield, C., Heard, M.E., Heathcote, R., Heaver, D., Holland, J., Howe, M., Hughes, B., Huxley, Y., Kunin, W.E., Little, J., Mason, C., Memmott, J., Osborne, J., 
Pankhurst, T., Paxton, R.J., Pocock, M.J.O., Potts, S.G., Power, E.F., Raine, N.E., Ranelagh, E., Roberts, S., Saunders, R., Smith, K., Smith, R.M., Sutton, P., Tilley, L.A.N., Tinsley, A., Tonhasca, A., Vanbergen, A.J., Webster, S., Wilson, A. \& Sutherland, W.J. (2013) Identifying key knowledge needs for evidence-based conservation of wild insect pollinators: a collaborative cross-sectoral exercise Insect Conservation and Diversity, 6, 435 - 446.

Dicks, L.V., Baude, M.E., Roberts, S.P.M., Phillips, J., Green, M. \& Carvell, C. (2015) How much flower-rich habitat is enough for wild pollinators? Answering a key policy question with incomplete knowledge. Ecological Entomology. 40, 22 35

Dicks, L.V., Corbet, S.A. \& Pywell, R.F. (2002) Compartmentalization in plant-insect flower visitor webs. Journal of Animal Ecology, 71, 32-43.

Dworschak, K.A.I. \& Bluthgen, N. (2010) Networks and dominance hierarchies: does interspecific aggression explain flower partitioning among stingless bees? Ecological Entomology, 35, 216-225.

Eastwood, A., Brooker, R., Irvine, R.J., Artz, R.R.E., Norton, L.R., Bullock, J.M., Ross, L., Fielding, D., Ramsay, S., Roberts, J., Anderson, W., Dugan, D., Cooksley, S. \& Pakeman, R.J. (2016) Does nature conservation enhance ecosystem services delivery? Ecosystem Services, 17, 152-162.

Ebeling, A., Klein, A.M. \& Tscharntke, T. (2011) Plant-flower visitor interaction webs: Temporal stability and pollinator specialization increases along an experimental plant diversity gradient. Basic and Applied Ecology, 12, 300309.

Ekroos, J., Rundlof, M. \& Smith, H.G. (2013) Trait-dependent responses of flowervisiting insects to distance to semi-natural grasslands and landscape heterogeneity. Landscape Ecology, 28, 1283-1292.

Ellis, C.R., Feltham, H., Park, K., Hanley, N. \& Goulson, D. (2017) Seasonal complementary in pollinators of soft-fruit crops. Basic and Applied Ecology, $19,45-55$.

Evans, D. (2012) Building the European Union's Natura 2000 network. Nature Conservation-Bulgaria, 11-26. 
Falk, S. \& Lewington, R. (2015) Field Guide to the Bees of Great Britain and Ireland, First Edition edn. Bloomsbury, London.

Feltham, H., Park, K., Minderman, J. \& Goulson, D. (2015) Experimental evidence that wildflower strips increase pollinator visits to crops. Ecology and Evolution, 5, 3523-3530.

Forup, M.L., Henson, K.S.E., Craze, P.G. \& Memmott, J. (2008) The restoration of ecological interactions: Plant-pollinator networks on ancient and restored heathlands. Journal of Applied Ecology, 45, 742-752.

Garibaldi, L., Steffan-Dewenter, I., Winfree, R., Aizen, M., Bommarco, R., Cunningham, S., Kremen, C., Carvalheiro, L., Harder, L., Afik, O., Bartomeus, I., Benjamin, F., Boreux, V., Cariveau, D., Chacoff, N., Dudenhoffer, J., Freitas, B., Ghazoul, J., Greenleaf, S., Hipolito, J., Holzschuh, A., Howlett, B., Isaacs, R., Javorek, S., Kennedy, C., Krewenka, K., Krishnan, S., Mandelik, Y., Mayfield, M., Motzke, I., Munyuli, T., Nault, B., Otieno, M., Petersen, J., Pisanty, G., Potts, S., Rader, R., Ricketts, T., Rundlof, M., Seymour, C., Schuepp, C., Szentgyorgyi, H., Taki, H., Tscharntke, T., Vergara, C., Viana, B., Wanger, T., Westphal, C., Williams, N. \& Klein, A. (2013) Wild Pollinators Enhance Fruit Set of Crops Regardless of Honey Bee Abundance. Science, 339, 1608-1611.

Garibaldi, L.A., Steffan-Dewenter, I., Kremen, C., Morales, J.M., Bommarco, R., Cunningham, S.A., Carvalheiro, L.G., Chacoff, N.P., Dudenhoffer, J.H., Greenleaf, S.S., Holzschuh, A., Isaacs, R., Krewenka, K., Mandelik, Y., Mayfield, M.M., Morandin, L.A., Potts, S.G., Ricketts, T.H., Szentgyorgyi, H., Viana, B.F., Westphal, C., Winfree, R. \& Klein, A.M. (2011) Stability of pollination services decreases with isolation from natural areas despite honey bee visits. Ecology Letters, 14, 1062-1072.

Gathmann, A. \& Tscharntke, T. (2002) Foraging ranges of solitary bees. Journal of Animal Ecology, 71, 757-764.

Gilbert, F.S. (1981) Foraging ecology of hoverflies: morphology of the mouthparts in relation to feeding on nectar and pollen in some common urban species. Ecological Entomology, 6, 245 - 262.

Gill, R.J., Baldock, K.C.R., Brown, M.J.F., Cresswell, J.E., Dicks, L.V., Fountain, M.T., Garratt, M.P.D., Gough, L.A., Heard, M.S., Holland, J.M., Ollerton, J., Stone, G.N., 
Tang, C.Q., Vanbergen, A.J., Vogler, A.P., Woodward, G., Arce, A.N., Boatman, N.D., Brand-Hardy, R., Breeze, T.D., Green, M., Hartfield, C.M., O’Connor, R.S., Osborne, J.L., Phillips, J., Sutton, P.B. \& Potts, S.G. (2016) Protecting an Ecosystem Service: Approaches to Understanding and Mitigating Threats to Wild Insect Pollinators. Advances in Ecological Research, 54, 135 - 206.

Gillespie, M.A.K., Gurr, G.M. \& Wratten, S.D. (2016) Beyond nectar provision: the other resource requirements of parasitoid biological control agents. Entomologia Experimentalis et Applicata, 159, 207 - 221.

Goulson, D., Nicholls, E. \& Botías, C.R., E.L. (2015) Bee declines driven by combined stress from parasites, pesticides, and lack of flowers. Science, 347. doi: $10.1126 /$ science. 1255957

Habel, J.C., Dengler, J., Janiskova, M., Torok, P., Wellstein, C. \& Wiezik, M. (2013) European grassland ecosystems:threatened hotspots of biodiversity. Biodiversity and Conservation, 22, 2131 - 2138.

Hardman, C.J., Harrison, D.P., Shaw, P.J., Nevard, T.D., Hughes, B., Potts, S.G. \& Norris, K. (2016) Supporting local diversity of habitats and species on farmland: a comparison of three wildlife-friendly schemes. J Appl Ecol, 53, 171-180.

Haslett, J.R. (1989) Adult feeding by holometabolous insects: pollen and nectar as complementary nutrient sources for Rhingia campestris (Diptera: Syrphidae). Oecologia, 81, 361-363.

Hickman, J.M., Wratten, S.D., Jepson, P.C. \& Frampton, C.M. (2001) Effect of hunger on yellow water trap catches of hoverfly (Diptera: Syrphidae) adults. Agricultural and Forest Entomology, 3, 35-40.

Hill, M.O., Mountford, J.O., Roy, D.B. \& Bunce, R.G.H. (1999) Ellenberg's indicator values for British plants., pp. 46. Institute of Terrestrial Ecology, Huntingdon.

Hudewenz, A., Klein, A.-M., Scherber, C., Stanke, L., Tscharntke, T., Vogel, A., Weigelt, A., Weisser, W.W. \& Ebeling, A. (2012) Herbivore and pollinator responses to grassland management intensity along experimental changes in plant species richness. Biological Conservation, 150, 42-52.

IPBES (2016) Summary for policymakers of the assessment report of the Intergovernmental Science-Policy Platform on Biodiversity and Ecosystem Services on pollinators, pollination and food production. (eds S.G. Potts, V.L. 
Imperatriz-Fonseca, H.T. Ngo, J.C. Biesmeijer, T.D. Breeze, L.V. Dicks, L.A. Garibaldi, R. Hill, J. Settele, A.J. Vanbergen, M.A. Aizen, S.A. Cunningham, C. Eardley, B.M. Freitas, N. Gallai, P.G. Kevan, A. Kovács-Hostyánszki, P.K. Kwapong, J. Li, X. Li, D.J. Martins, G. Nates-Parra, J.S. Pettis, R. Rader \& B.F. Viana), pp. 36 pages. Secretariat of the Intergovernmental Science-Policy Platform on Biodiversity and Ecosystem Services, Bonn, Germany.

Jauker, F., Bondarenko, B., Becker, H.C. \& Steffan-Dewenter, I. (2012) Pollination efficiency of wild bees and hoverflies provided to oilseed rape. Agricultural and Forest Entomology, 14, 81-87.

Jauker, F. \& Wolters, V. (2008) Hover flies are efficient pollinators of oilseed rape. Oecologia, 156, 819-823.

Jerrentrup, J.S., Wrage-Monnig, N., Rover, K. \& Isselstein, J. (2014) Grazing intensity affects insect diversity via sward structure and heterogeneity in a long-term experiment. Journal of Applied Ecology, 51, 968 - 977.

Jönsson, A.M., Ekroos, J., Dänhardt, J., Andersson, G.K.S., Olsson, O. \& Smith, H.G. (2015) Sown flower strips in southern Sweden increase abundances of wild bees and hoverflies in the wider landscape. Biological Conservation, 184, 5158.

Klein, A., Vaissière, B.E., Cane, J.H., Steffan-Dewenter, I., Cunningham, S.A., Kremen, C. \& Tscharntke, T. (2007) Importance of pollinators in changing landscapes for world crops. Proceedings of the Royal Society B, 274, 303 - 313.

Koch, B., Edwards, P.J., Blanckenhorn, W.U., Buholzer, S., Walter, T., Wueest, R.O. \& Hofer, G. (2013) Vascular plants as surrogates of butterfly and grasshopper diversity on two Swiss subalpine summer pastures. Biodiversity and Conservation, 22, 1451-1465.

Kovács-Hostyánszki, A., Espíndola, A., Vanbergen, A.J., Settele, J., Kremen, C. \& Dicks, L.V. (2017) Ecological intensification to mitigate impacts of conventional intensive land use on pollinators and pollination. Ecology Letters, 20: 673689. doi:10.1111/ele.12762

Laubertie, E.A., Wratten, S.D. \& Sedcole, J.R. (2006) The role of odour and visual cues in the pan-trap catching of hoverflies (Diptera : Syrphidae). Annals of Applied Biology, 148, 173-178. 
Lazaro, A., Tscheulin, T., Devalez, J., Nakas, G. \& Petanidou, T. (2016) Effects of grazing intensity on pollinator abundance and diversity, and on pollination services. Ecological Entomology, 41, 400 - 412.

Lentini, P.E., Martin, T.G., Gibbons, P., Fischer, J. \& Cunningham, S.A. (2012) Supporting wild pollinators in a temperate agricultural landscape: Maintaining mosaics of natural features and production. Biological Conservation, 149, 84-92.

Lüscher, G., Ammari, Y., Andriets, A., Angelova, S., Arndorfer, M., Bailey, D., Balázs, K., Bogers, M., Bunce, R.G.H., Choisis, J.-P., Dennis, P., Díaz, M., Dyman, T., Eiter, S., Fjellstad, W., Fraser, M., Friedel, J.K., Garchi, S., Geijzendorffer, I.R., Gomiero, T., González-Bornay, G., Guteva, Y., Herzog, F., Jeanneret, P., Jongman, R.H.G., Kainz, M., Kwikiriza, N., Díaz, M.L.L., Moreno, G., Nicholas-Davies, P., Nkwiine, C., Opio, J., Paoletti, M.G., Podmaniczky, L., Pointereau, P., Pulido, F., Sarthou, J.-P., Schneider, M.K., Sghaier, T., Siebrecht, N., Stoyanova, S., Wolfrum, S., Yashchenko, S., Albrecht, H., Báldi, A., Belényesi, M., Benhadi-Marin, J., Blick, T., Buholzer, S., Centeri, C., Choisis, N., Cuendet, G., De Lange, H.J., Déjean, S., Deltshev, C., Cosín, D.J.D., Dramstad, W., Elek, Z., Engan, G., Evtushenko, K., Falusi, E., Finch, O.-D., Frank, T., Gavinelli, F., Genoud, D., Gillingham, P.K., Grónás, V., Gutiérrez, M., Häusler, W., Heer, X., Hübner, T., Isaia, M., Jerkovich, G., Jesus, J.B., Kakudidi, E., Kelemen, E., Koncz, N., Kovacs, E., KovácsHostyánszki, A., Last, L., Ljubomirov, T., Mandery, K., Mayr, J., Mjelde, A., Muster, C., Nascimbene, J., Neumayer, J., Ødegaard, F., Sánchez, F.J.O., Oschatz, M.-L., Papaja-Hülsbergen, S., Paschetta, M., Pavett, M., Pelosi, C., Penksza, K., Pommeresche, R., Popov, V., Radchenko, V., Richner, N., Riedel, S., Scullion, J., Sommaggio, D., Szalkovszki, O., Szerencsits, E., Trigo, D., Vale, J., van Kats, R., Vasilev, A., Whittington, A.E., Wilkes-Allemann, J. \& Zanetti, T. (2016) Farmland biodiversity and agricultural management on 237 farms in 13 European and 2 African regions. Ecology.

Mace, G., Norris, K. \& Fitter, A. (2012) Biodiversity and ecosystem services: a multilayered relationship. Trends in Ecology \& Evolution, 27, 19-26.

Mayer, C., Adler, L., Armbruster, S., Dafni, A., Eardley, C., Huang, S., Kevan, P.G., Ollerton, J., Packer, L., Ssymank, A., Stout, J.C. \& Potts, S.G. (2011) Pollination 
ecology in the the 21st century: key questions for future research. Journal of Pollination Ecology, 3, 8 - 23.

Meyer, B., Jauker, F. \& Steffan-Dewenter, I. (2009) Contrasting resource-dependent responses of hoverfly richness and density to landscape structure. Basic and Applied Ecology, 10, 178-186.

Moisan-Deserres, J., Girard, M., Chagnon, M. \& Fournier, V. (2014) Pollen Loads and Specificity of Native Pollinators of Lowbush Blueberry. Journal of Economic Entomology, 107, $1156-1162$

Mucina, L., Bültmann, H., Dierßen, K., Theurillat, J.-P., Raus, T., Čarni, A., Šumberová, K., Willner, W., Dengler, J., García, R.G., Chytrý, M., Hájek, M., Di Pietro, R., Iakushenko, D., Pallas, J., Daniëls, F.J.A., Bergmeier, E., Santos Guerra, A., Ermakov, N., Valachovič, M., Schaminée, J.H.J., Lysenko, T., Didukh, Y.P., Pignatti, S., Rodwell, J.S., Capelo, J., Weber, H.E., Solomeshch, A., Dimopoulos, P., Aguiar, C., Hennekens, S.M. \& Tichý, L. (2016) Vegetation of Europe: hierarchical floristic classification system of vascular plant, bryophyte, lichen, and algal communities. Applied Vegetation Science, 19, 3-264.

Mueller, A.L. \& Dauber, J. (2016) Hoverflies (Diptera: Syrphidae) benefit from a cultivation of the bioenergy crop Silphium perfoliatum L. (Asteraceae) depending on larval feeding type, landscape composition and crop management. Agricultural and Forest Entomology, 18, 419-431.

Ockinger, E., Lindborg, R., Sjodin, N.E. \& Bommarco, R. (2012) Landscape matrix modifies richness of plants and insects in grassland fragments. Ecography, 35, 259-267.

Ockinger, E. \& Smith, H.G. (2007) Semi-natural grasslands as population sources for pollinating insects in agricultural landscapes. Journal of Applied Ecology, 44, $50-59$.

Ollerton, J., Winfree, R. \& Tarrant, S. (2011) How many flowering plants are pollinated by animals? Oikos, 120, 321-326.

Orford, K.A., Murray, P.J., Vaughan, I.P. \& Memmott, J. (2016) Modest enhancements to conventional grassland diversity improve the provision of pollination services. Journal of Applied Ecology, 53, 906 - 915. 
Popic, T.J., Davila, Y.C. \& Wardle, G.M. (2013) Evaluation of Common Methods for Sampling Invertebrate Pollinator Assemblages: Net Sampling Out-Perform Pan Traps. PLOS ONE, 8, e66665.

Potts, S., Biesmeijer, J., Kremen, C., Neumann, P., Schweiger, O. \& Kunin, W. (2010) Global pollinator declines: trends, impacts and drivers. Trends in Ecology \&amp; Evolution, 25, 345-353.

Potts, S.G., Imperatriz-Fonseca, V., Ngo, H.T., Aizen, M.A., Biesmeijer, J.C., Breeze, T.D., Dicks, L.V., Garibaldi, L.A., Hill, R., Settele, J. \& Vanbergen, A.J. (2016) Safeguarding pollinators and their values to human well-being. Nature. 540, $220-229$

Power, E.F., Jackson, Z. \& Stout, J.C. (2016) Organic farming and landscape factors affect abundance and richness of hoverflies (Diptera, Syrphidae) in grasslands. Insect Conservation and Diversity, 9, 244 - 253.

Power, E.F. \& Stout, J.C. (2011) Organic dairy farming: impacts on insect-flower interaction networks and pollination. Journal of Applied Ecology, 48, 561-569.

Prodorutti, D. \& Frilli, F. (2008) Entomophilous pollination of raspberry, red currant and highbush blueberry in a mountain area of Friuli-Venezia Giulia (northeastern Italy). Proceedings of the Ixth International Rubus and Ribes Symposium (eds P. Banados \& A. Dale), pp. 429-434.

R Core Team (2014) R: a language and environment for statistical computing., pp. http://www.R-project.org R Foundation for Statistical Computing, Vienna, Austria.

Radcliffe, D.A.e. (1989) Guidelines for selection of biological SSSIs. Nature Conservancy Council, Peterborough.

Rader, R., Edwards, W., Westcott, D.A., Cunningham, S.A. \& Howlett, B.G. (2011) Pollen transport differs among bees and flies in a human-modified landscape. Diversity and Distributions, 17, 519-529.

Rader, R., Bartomeus, I., Garibaldi, L.A., Garratt, M.P.D., Howlett, B.G., Winfree, R., Cunningham, S.A., Mayfield, M.M., Arthur, A.D., Andersson, G.K.S., Bommarco, R., Brittain, C., Carvalheiro, L.G., Chacoff, N.P., Entling, M.H., Foully, B., Freitas, B.M., Gemmill-Herren, B., Ghazoul, J., Griffin, S.R., Gross, C.L., Herbertsson, L., Herzog, F., Hipólito, J., Jaggar, S., Jauker, F., Klein, A.-M., Kleijn, D., Krishnan, S., 
Lemos, C.Q., Lindström, S.A.M., Mandelik, Y., Monteiro, V.M., Nelson, W., Nilsson, L., Pattemore, D.E., de O. Pereira, N., Pisanty, G., Potts, S.G., Reemer, M., Rundlöf, M., Sheffield, C.S., Scheper, J., Schüepp, C., Smith, H.G., Stanley, D.A., Stout, J.C., Szentgyörgyi, H., Taki, H., Vergara, C.H., Viana, B.F. \& Woyciechowski, M. (2015) Non-bee insects are important contributors to global crop pollination. Proceedings of the National Academy of Sciences, 113, $146-151$.

Ricketts, T.H., Regetz, J., Steffan-Dewenter, I., Cunningham, S.A., Kremen, C., Bogdanski, A., Gemmill-Herren, B., Greenleaf, S.S., Klein, A.M., Mayfield, M.M., Morandin, L.A., Ochieng, A., Potts, S.G. \& Viana, B.F. (2008) Landscape effects on crop pollination services: are there general patterns? Ecology Letters, 11, $499-515$.

Rodwell, J., Pigott, C.D., Ratcliffe, D.A., Malloch, A.J.C., Birks, H.J.B., Proctor, M.C.F., Shimwell, D.W., Huntley, J.P., Radford, E., Wigginton, M.J. \& Wilkins, P. (1992) British Plant Communities Volume 3: Grasslands and montane communities. Cambridge University Press, Cambridge.

Rodwell, J., Pigott, C.D., Ratclliffe, D.A., Malloch, A.J.C., Proctor, M.C.F., Shimwell, D.W., Huntley, J.P., Radford, E., Wigginton, M.J. \& Wilkins, P. (1991) British Plant Communities Volume 2. Mires and heaths. Cambridge University Press, Cambridge.

Rose, F. (2006) The Wild Flower Key, 2nd Ed. edn. Penguin Group, London.

Rotheray, G.E. \& Gilbert, F. (2011) The Natural History of Hoverflies. Forrest Text, Cardigan.

Roulston, T.a.H., Smith, S.A. \& Brewster, A.L. (2007) A Comparison of Pan Trap and Intensive Net Sampling Techniques for Documenting a Bee (Hymenoptera: Apiformes) Fauna. Journal of the Kansas Entomological Society, 80, 179-181.

Rzanny, M. \& Voigt, W. (2012) Complexity of multitrophic interactions in a grassland ecosystem depends on plant species diversity. Journal of Animal Ecology, 81, 614-627.

Schaffers, A.P., Raemakers, I.P., Sykora, K.V. \& Ter Braak, C.J.F. (2008) Arthropod assemblages are best predicted by plant species composition. Ecology, 89, 782-794. 
Schweiger, O., Musche, M., Bailey, D., Billeter, R., Diekotter, T., Hendrickx, F., Herzog, F., Liira, J., Maelfait, J.P., Speelmans, M. \& Dziock, F. (2007) Functional richness of local hoverfly communities (Diptera, Syrphidae) in response to land use across temperate Europe. Oikos, 116, 461-472.

Senapathi, D., Carvalheiro, L.G., Biesmeijer, J.C., Dodson, C., Evans, R.L., McKerchar, M., Morton, D.R., Moss, E.D., Roberts, S.P.M., Kunin, W.E. \& Potts, S.G. (2015) The impact of over 80 years of land cover changes on bee and wasp pollinator communities in England. Proceedings of the Royal Society B, 282, DOI: $10.1098 / \mathrm{rspb} .2015 .0294$.

Spafford, R.D. \& Lortie, C.J. (2013) Sweeping beauty: Is grassland arthropod community composition effectively estimated by sweep netting? Ecology and Evolution, 3, 3347-3358.

Stavert, J.R., Liñán-Cembrano, G., Beggs, J.R., Howlett, B.G., Pattemore, D.E. \& Bartomeus, I. (2016) Hairiness: the missing link between pollinators and pollination. PeerJ, 4, e2779.

Stevens, D.P. \& Mockridge, C.P. (2004) A vegetation survey and conservation assessment of lowland grasslands in West Glamorgan \& Llanelli Borough. . Countryside Council for Wales, Bangor.

Stubbs, A.E. \& Falk, S.J. (2002a) British Hoverflies. An illustrated identification guide. BENHS, Reading.

Stubbs, A.E. \& Falk, S.J. (2002b) British Hoverflies. An illustrated identification guide. British Hoverflies. An illustrated identification guide. BENHS, Reading.

Van Dijk, G. (1991) The status of semi-natural grasslands in Europe. The Conservation of Lowland Dry Grassland bBrds in Europe (eds P.D. Goriup, L.A. Batten \& J.A. Norton), pp. 15 - 36. Joint Nature Conservation Committee, Peterborough.

Vanbergen, A., Baude, M., Biesmeijer, J., Britton, N., Brown, M., Brown, M., Bryden, J., Budge, G., Bull, J., Carvel, C., Challinor, A., Connolly, C., Evans, D., Feil, E., Garratt, M., Greco, M., Heard, M., Jansen, V., Keeling, M., Kunis, W., Marris, G., Memmott, J., Murray, J., Nicolson, S., Osborne, J., Paxton, R., Pirk, C., Polce, C., Potts, S., Priest, N., Raine, N., Roberts, S., Ryabov, E., Shafir, S., Shirley, M., Simpson, S., Stevenson, P., Stone, G., Termansen, M., Wright, G. \& Initiative, I.P. 
(2013) Threats to an ecosystem service: pressures on pollinators. Frontiers in Ecology and the Environment, 11, 251-259.

Vanbergen, A.J., Woodcock, B.A., Gray, A., Grant, F., Telford, A., Lambdon, P., Chapman, D.S., Pywell, R.F., Heard, M.S. \& Cavers, S. (2014) Grazing alters insect visitation networks and plant mating systems. Functional Ecology, 28, $178-189$.

Verdu, J.R., Morenob, C.E., Sanchez-Rojasb, G., Numaa, C., Galantea, E. \& Halffterc, G. (2007) Grazing promotes dung beetle diversity in the xeric landscapeof a Mexican Biosphere Reserve. Biological Conservation, 140, 308 - 317.

Vickery, J.A., Tallowin, J.R., Feber, R.E., Asteraki, E.J., Atkinson, P.W., Fuller, R.J. \& Brown, V.K. (2001) The management of lowland neutral grasslands in Britain: effects of agricultural practices on birds and their food resources. Journal of Applied Ecology, 38, 647-664.

Weiner, C.N., Werner, M., Linsenmair, K.E. \& Blüthgen, N. (2011) Land use intensity in grasslands: Changes in biodiversity, species composition and specialisation in flower visitor networks. Basic and Applied Ecology, 12, 292-299.

Welsh Government (2013) An Action Plan for Pollinators. Welsh Government, Aberystwyth.

Wheater, C.P. \& Cook, P.A. (2003) Studying Invertebrates. The Richmond Publishing Company, Slough.

Wilson, J.S., Griswold, T. \& Messinger, O.J. (2008) Sampling Bee Communities (Hymenoptera: Apiformes) in a Desert Landscape: Are Pan Traps Sufficient? Journal of the Kansas Entomological Society, 81, 288-300.

Wratten, S.D., Bowie, M.H., Hickman, J.M., Evans, A.M., Sedcole, J.R. \& Tylianakis, J.M. (2003) Field boundaries as barriers to movement of hover flies (Diptera : Syrphidae) in cultivated land. Oecologia, 134, 605-611.

Yanahan, A.D. \& Taylor, S.J. (2014) Vegetative communities as indicators of ground beetle (Coleoptera: Carabidae) diversity. Biodiversity and Conservation, 23, $1591-1609$. 


\title{
Chapter 3
}

\section{Timing of peak emergence and influence of}

temperature and rainfall on hoverfly populations in

\section{fen-meadow grasslands.}

\author{
Andrew Lucas, James C Bull, Natasha de Vere, Penelope J Neyland, and \\ Dan W. Forman
}

Andrew Lucas conceived the study, undertook fieldwork, all data collection, statistical analysis, and drafted the manuscript. James C Bull undertook statistical analysis, and drafting of manuscript. Natasha de Vere advised on drafting the manuscript. Penelope J Neyland advised on statistical analysis and drafting the manuscript. Dan W Forman helped to conceive the study, advised on statistical analysis, and helped draft the manuscript. 


\section{Summary}

1. Climate change is already having effects on pollinator populations, including alterations to phenology and shifts in species ranges. This will cause changes to local pollinator species assemblages both spatially and temporally. However, changes in pollinator abundance and species richness in response to weather conditions are relatively little studied.

2. We investigated the effect of weather on hoverfly abundance and species richness at four fen-meadow sites in west Wales, UK, using a four-year data set of samples collected between June and September. Using generalised additive modelling we investigated the effects of ordinal date, rainfall, mean temperature, and insolation on hoverfly populations.

3. Statistically significant responses were limited, possibly reflecting the restricted data and other factors influencing hoverfly populations. However, abundance and species-richness increased with ordinal date over the survey period at three sites. Hoverfly abundance increased with insolation at one site. At two sites, hoverfly abundance was highest at a mean daily temperature of approximately $15^{\circ} \mathrm{C}$, with declines at higher and lower temperatures. Rainfall showed a similar pattern, with abundance highest in moderate rainfall and lower in dry and wet conditions. Conversely, species-richness declined with increasing insolation at one site, and also declined with increasing mean daily temperature.

4. Most climate-related pollinator studies focus on long-term changes in phenology and distribution. However, these changes will be a cumulative response to varying weather conditions. Given predicted changes in summer temperature and rainfall in Britain, more refined modelling is needed to further explore direct pollinator responses to weather as climate changes. 


\section{Introduction}

Anthropogenic climate change and a consequent warming of the global climate system, caused primarily by the burning of fossil fuels, is now unequivocal (IPCC 2013), with effects on ecosystems having already been demonstrated (Walther et al. 2002). The implications for natural ecosystems include the extinction of species (Thomas et al. 2004; Urban 2015) and the disruption of community functioning (Schmidt et al. 2016). There is particular concern regarding the impact that climate change may have on pollinator communities, populations and species, because pollination is an ecosystem service critical for both food production and also wider ecosystem function (Potts et al. 2010; Ollerton, Winfree \& Tarrant 2011; Breeze et al. 2016). The high nutritional value of many pollinator-dependent crops makes them important to human health and wellbeing (Smith et al. 2015).

Climate change has been predicted to result in changes in the distribution of plants on which pollinators depend, degradation of habitats, and species extinctions (Thomas et al. 2004; Urban 2015). These impacts may combine to have unpredictable effects on pollinator populations. Changes in regional climate may also induce phenological shifts (Roy \& Sparks 2000; Sparks, Jeffree \& Jeffree 2000), causing pollinator populations to be no longer in synchrony with key plant species (Memmott et al. 2007; Hegland et al. 2009; Burkle \& Knight 2012; Schmidt et al. 2016). Increasing temperatures are predicted to result in an 'upward and poleward' change in species distribution (Chen et al. 2011; IPBES 2016) although, in some species, contractions in range at low latitudes have not been matched by range expansion at high latitudes (Kerr et al. 2015). The effects of climate change can vary significantly between pollinator guilds. For example, coldadapted pollinators can expend more energy on thermoregulation as climate warms (Rasmont \& Iserbyt 2012). In bees, temperature can have contrasting impacts on pupal and adult mortality (Radmacher \& Strohm 2011) or changes in social structure in socially plastic species (Schurch, Accleton \& Field 2016). These impacts will act collectively to alter the composition of species' assemblages, as pollinator species arrive at, or depart from, particular locations (Polce et al. 2013).

However, in contrast to phenological and species distribution effects, the direct effect of changing weather conditions as a consequence of climate change on pollinator abundance 
and species-richness has been relatively little studied (Scaven \& Rafferty 2013). Higher temperatures can influence the physiology and behaviour of pollinator insects. For example, changes in air temperature have been shown to alter patterns of flower visitation in a number of pollinator guilds (Willmer 1983). Elevated temperatures can also affect both pupal development and adult survival in bees (Radmacher \& Strohm 2011), and affect the life-span of solitary bees (Sgolastra et al. 2011). Changes in temperature can also affect the resources on which pollinators depend. Temperature can affect nectar production (Petanidou \& Smets 1996; Takkis et al. 2015), and influence the volume and viability of pollen (Koti et al. 2005). In addition, elevated temperatures can determine whether a plant produces flowers (Liu et al. 2012) as well as flowering timing and duration (Jagadish et al. 2016). Crops can also vary in their dependency on pollinators, depending on the amount of heat stress they experience (Bishop et al. 2016). These varying impacts on plants and their pollinators will act synergistically to have farreaching effects on plant-pollinator systems (Hoover et al. 2012).

Although most studies on pollinators and climate change have focussed on bees (Le Conte \& Navajas 2008; Giannini et al. 2012; Miller-Struttmann et al. 2015), flies (Diptera) are also important pollinators of a range of crops and wild plant species (Orford, Vaughan \& Memmott 2015; Rader et al. 2015). Amongst Diptera species, hoverflies (Syrphidae) have an important role in pollination (Pontin et al. 2006; Jauker et al. 2012; Grass et al. 2016). Climate change has been shown to affect hoverfly phenology, with earlier emergence dates, longer flight periods and an increase in voltinism (GrahamTaylor, Stubbs \& Brooke 2009; Hassall, Owen \& Gilbert 2016). Although hoverflies may maintain synchrony with flowers, climate change may lead to particular hoverfly species having reduced overlap with the flowering period of some plant species (Iler et al. 2013).

The most recent climate projections for the United Kingdom ('UKCP09') (Murphy et al. 2009) suggest that, under a medium emissions scenario, all areas of the UK will experience an increase in summer mean temperature by 2050. This warming ranges from a central estimate of change of $4.2^{\circ} \mathrm{C}$ in southern England to $2.5^{\circ} \mathrm{C}$ in northwest Scotland, with mean daily maximum temperatures rising by $5.4^{\circ} \mathrm{C}$ in southern England, and $2.8^{\circ} \mathrm{C}$ in northern Britain. Concurrently, the UKCP09 central estimate for annual precipitation shows little change, but estimates for change in summer precipitation vary 
from $-40 \%$ in southern England to close to zero in northern Scotland. These changes are mirrored in Wales, where the UKCP09 central estimate of summer mean temperature increase is $2.5^{\circ} \mathrm{C}$, with a central estimate of summer precipitation declining by $16 \%$. Given these projected changes, there is an urgent need to evaluate how they may impact plant-pollinator interactions. However, the implications of changes in climate for pollinators, and specifically for hoverflies, are unclear; understanding the impacts of climate change on pollinators has been identified as a key knowledge requirement (Dicks et al. 2013).

The aim of this study was to investigate if hoverfly abundance and species-richness was impacted by weather and ordinal date at four fen-meadow conservation grasslands in west Wales, UK. These grasslands are botanically species-rich (Rodwell et al. 1991), and are considered to be of conservation importance at a UK and European level (Radcliffe 1989; McLeod et al. 2009). They also have the potential to provide ecosystem services, such as pollinator populations, to the wider countryside (Christie \& Raiment 2012). Such grasslands have also been shown to be important habitats for hoverflies, with relatively high hoverfly abundance and a distinctive species assemblage (Lucas et al. 2017).

Pan-trapping was used to investigate hoverfly populations during the main flight period of June to early September over four years from 2011 to 2014. We obtained data from a nearby weather station for the same period. Using generalised additive modelling (GAMs) we explored whether the weather-related metrics rainfall, mean temperature, and insolation, as well as ordinal date, were related to hoverfly abundance and species richness. Our prediction was that hoverflies would become more abundant and speciesrich as the summer flight period progressed, but would be less abundant and less speciesrich during periods when rainfall was high, and temperatures and insolation low. These predictions were based on observations of hoverfly natural history (Ball \& Morris 2013). We then related our results to climate predictions for the UK, to infer what impact future climate change may have on pollinator hoverfly populations.

\section{Methods}

Four grassland sites were used for this study, hereafter referred to as 'CAD', 'LLC', 'RHC' and 'TRE'. 


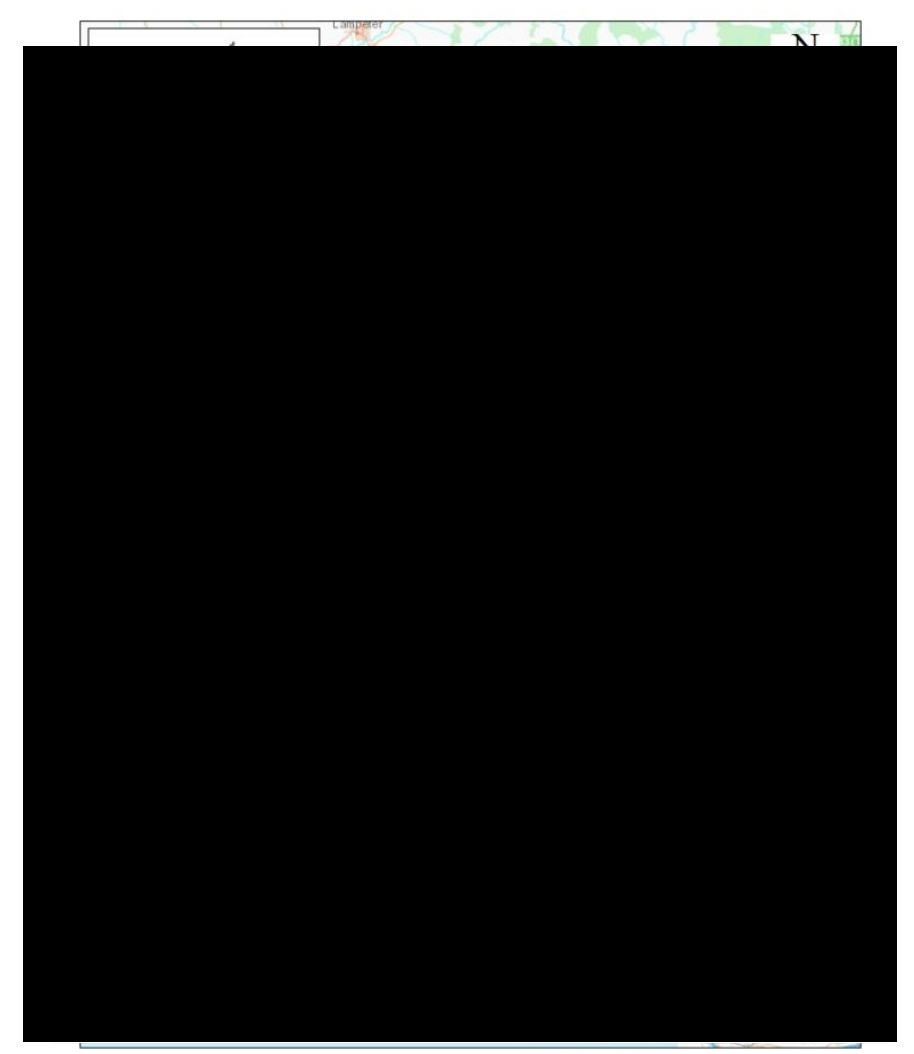

Figure 10 Location of field sites used in this study.

Further information on these sites is included in the supplementary information. All these sites are conservation grasslands in which the National Vegetation Community (NVC) M24 Molinia caerulea - Cirsium dissectum fen-meadow is present, in a mosaic with other mire and grassland communities. M24 is a species-rich community found on moist peaty, but slightly base-enriched soils. Insects were collected during at least five sample intervals between June 1 and September 15 for four years annually between 2011 and 2014 (sites LLC, RHC and TRE) and for three years between 2012 and 2014 (site CAD). The number of sample intervals varied between years, with six sample intervals in 2011 (year 1), five sample intervals in 2012 (year 2), and seven each in 2013 and 2014 (years 3 and 4).

Insect pan-trapping methods were similar to those described in Lucas et al. (2017). Nine plastic bowls (340 $\mathrm{mm}$ diameter and $128 \mathrm{~mm}$ depth) were used as pan traps, supplied in 
three colours by the manufacturer: white, blue and yellow (Laubertie, Wratten \& Sedcole 2006). These were mounted on metal stands, set up and fenced to protect them from stock. All of the grasslands studied were under grazing management, using combinations of cattle, horses and sheep, but grazing was not under experimental control.

Pan traps were filled with water to a depth of approximately $10 \mathrm{~cm}$, to which approximately $0.25 \mathrm{ml}$ of detergent and approximately $50 \mathrm{ml}$ of ethylene glycol was added (Wheater \& Cook 2003). They were then left for four days, and emptied within $+/-$ one hour of the time they had originally been set. Insects were sieved from the water (sieve mesh size $2 \mathrm{~mm}^{2}$ ) and placed in bottles of $70 \%$ ethanol for identification. Pan traps were then covered or emptied for ten days, before the next sample interval. Samples from each sample interval at a site were pooled for further analysis

Insect samples were sorted to remove hoverflies, which were then identified morphologically under a light microscope (x20 - x40) using Stubbs and Falk (2002).

Data from all pan traps were combined to give one result for each sample site, as the close proximity of the traps meant that the samples were not independent. We calculated hoverfly abundance and species richness for each sample interval. Hoverflies of the genus Sphaerophoria, which can only be identified to species in males, were grouped as one category 'Sphaerophoria spp'. The date on which a sample was collected was noted, and converted to an ordinal date number, to be associated with hoverfly abundance, species-richness and meteorological data.

\section{Climate data}

A number of climate metrics were obtained from the Aberporth weather station supplied by the UK Met Office (Met Office Data Licence for Non-Commercial Use No. 010076939). This station is approximately $50 \mathrm{~km}$ to the northwest from the sample sites in this study (latitude $52.14^{\circ} \mathrm{N}$, longitude $04.57^{\circ} \mathrm{W}$, altitude $133 \mathrm{~m}$ ). This site was selected because it is the closest weather station where measurements of all the required metrics were available. Since the weather in Wales is predominantly influenced by weather systems arriving from the Atlantic (Mayes 2013), the Aberporth site would not be in the rain shadow of the Cambrian Mountains, and would therefore be a better analogue for rainfall at the sample sites than weather stations to the east. 
Five climate metrics were obtained from the weather station data. These were daily maximum temperature, daily minimum temperature, daily mean temperature (all in degrees Celsius), daily total rainfall ( $\mathrm{mm}$ ) and daily total sunshine (hours). These records were available for all sample periods. Since pan trapping for insect samples was undertaken during four 24 hour periods (generally being set on Monday and collected on Friday), climate data was collected for each of the five days during which the traps were in operation. A mean daily figure for each climate metric was then calculated for each insect sample interval, which could then be associated with insect data from the same period.

\section{Statistical Analysis}

An initial investigation showed a significant correlation between mean temperature and maximum temperature (Pearsons' $\mathrm{r}=0.969, \mathrm{t}=37.74, \mathrm{p}<0.01$ ), and between mean temperature and minimum temperature (Pearson's $r=0.95, t=29.56, p<0.01$ ). There were no other significant correlations between other combinations of variables. Therefore, in all models, only mean temperature was used as an explanatory variable. To investigate the effect of date and weather conditions on hoverfly abundance and species richness, generalised additive modelling using cubic smoothing splines was undertaken. These were implemented using negative binomial error distributions and log link functions. Our first analysis investigated the effect of the explanatory variables sample date (ordinal date), mean temperature, $\ln ($ mean rainfall +0.01 ) (to account for zero values), mean insolation hours and year (as a factor) on the abundance of hoverflies at each site. Initially, these explanatory variables were included as main effects and pairwise interactions. Interaction terms were assessed by comparing AIC differences with and without terms. All GAMs were implemented using the "mgcv" package in R 3.1.4. (R Core Team 2014).

\section{Results}

\section{Overview}

In total, 2786 individuals of 46 species were identified (table 1 and Appendix 1). The most numerous taxon was Helophilus pendulus (1170 individuals, $42 \%$ of all hoverfly 
individuals recorded). Eristalis species comprised 1039 individuals (34.9\%), with the next largest taxon being Sericomyia silentis (184 individuals, 6.6\%). These three taxa collectively comprise $2325(83.5 \%)$ of all hoverflies recorded.

The abundance of hoverflies varied between years, from 13670 in 2014 to 291 in 2011 , although the differences in the number of samples taken at each site should be noted here. The abundance for 2012 was influenced by an exceptional emergence of Helophilus pendulus at site TRE in late August. The lowest abundance $(\mathrm{n}=5)$ was recorded in site LLC in 2013. 
Table 4 Total number of hoverflies recorded using pan traps at four grassland sites (CAD, LLC, RHC and 2014. 'Others' includes all species contributing less than $1 \%$ of the total. Note that site CAD was not s

\begin{tabular}{|c|ccc|cccc|cccc|}
\hline Species & $\mathbf{2 0 1 1}$ & $\mathbf{2 0 1 1}$ & $\mathbf{2 0 1 1}$ & $\mathbf{2 0 1 2}$ & $\mathbf{2 0 1 2}$ & $\mathbf{2 0 1 2}$ & $\mathbf{2 0 1 2}$ & $\mathbf{2 0 1 3}$ & $\mathbf{2 0 1 3}$ & $\mathbf{2 0 1 3}$ & $\mathbf{2 0 1 3}$ \\
Episyrphus balteatus & LLC & RHC & TRE & CAD & LLC & RHC & TRE & CAD & LLC & RHC & TRE \\
Eristalis arbustorum & 0 & 1 & 1 & 2 & 0 & 6 & 2 & 32 & 0 & 4 & 3 \\
Eristalis horticola & 1 & 13 & 2 & 2 & 0 & 50 & 70 & 1 & 0 & 5 & 0 \\
Eristalis intricarius & 0 & 46 & 1 & 1 & 1 & 93 & 5 & 37 & 0 & 54 & 1 \\
Eristalis nemorum & 1 & 4 & 9 & 2 & 0 & 10 & 2 & 1 & 1 & 1 & 3 \\
Eristalis pertinax & 3 & 6 & 4 & 0 & 2 & 112 & 12 & 7 & 0 & 10 & 1 \\
Eristalis tenax & 0 & 2 & 0 & 1 & 0 & 10 & 12 & 3 & 0 & 1 & 1 \\
Helophilus pendulus & 2 & 11 & 8 & 1 & 0 & 37 & 37 & 3 & 1 & 4 & 2 \\
Melanogaster hirtella & 46 & 49 & 6 & 16 & 24 & 77 & 636 & 92 & 0 & 45 & 10 \\
Melanostoma mellinum & 0 & 3 & 0 & 11 & 0 & 30 & 3 & 0 & 0 & 6 & 1 \\
Platycheirus granditarsus & 0 & 0 & 2 & 1 & 3 & 7 & 23 & 2 & 0 & 1 & 2 \\
Rhingia campestris & 2 & 2 & 1 & 1 & 0 & 1 & 1 & 0 & 0 & 7 & 1 \\
Sericomyia silentis & 0 & 8 & 7 & 1 & 2 & 3 & 3 & 1 & 0 & 3 & 0 \\
Syritta pipiens & 0 & 13 & 3 & 3 & 0 & 4 & 3 & 69 & 0 & 22 & 3 \\
Xylota segnis & 1 & 1 & 0 & 0 & 0 & 0 & 0 & 2 & 0 & 4 & 2 \\
Others & 0 & 0 & 1 & 0 & 0 & 0 & 1 & 3 & 0 & 2 & 2 \\
Total & 8 & 20 & 3 & 7 & 0 & 21 & 15 & 20 & 3 & 15 & 18 \\
Number Species & $\mathbf{6 4}$ & $\mathbf{1 7 9}$ & $\mathbf{4 8}$ & $\mathbf{4 9}$ & $\mathbf{3 2}$ & $\mathbf{4 6 1}$ & $\mathbf{8 2 5}$ & $\mathbf{2 7 3}$ & $\mathbf{5}$ & $\mathbf{1 8 4}$ & $\mathbf{5 0}$ \\
Total Abundance (year) & $\mathbf{1 1}$ & $\mathbf{2 2}$ & $\mathbf{1 5}$ & $\mathbf{1 5}$ & $\mathbf{5}$ & $\mathbf{2 4}$ & $\mathbf{2 1}$ & $\mathbf{1 9}$ & $\mathbf{5}$ & $\mathbf{2 5}$ & $\mathbf{2 0}$ \\
\hline
\end{tabular}




\section{Effect of Ordinal date and Weather on Hoverfly Abundance}

Table 2 shows the effects of ordinal date, mean insolation (hours) and mean temperature $\left({ }^{\circ} \mathrm{C}\right)$, and each sample site on hoverfly abundance, as well as the effects of mean rainfall $(\mathrm{mm})$ at all sites combined on hoverfly abundance. There were statistically significant effects of date at sites LLC, RHC and TRE; of insolation at site TRE; of mean daily temperature at sites CAD and LLC; and of mean rainfall $(\mathrm{mm})$ at all sites combined. The adjusted $\mathrm{R}^{2}$ value was 0.281 , and the model explained $75.3 \%$ of the variance. 
Table 5 Generalised Additive Model $(n=94)$ for the effect on hoverfly abundance of ordinal date ('Date'), insolation hours ('Sun') and mean daily temperature ('Tmean) at four grassland sites in west Wales, UK, plus effect of mean rainfall ('Ln(Rain)') at all four sites combined. Statistically significant results are shown in bold.

\begin{tabular}{|c|c|c|c|c|}
\hline $\begin{array}{c}\text { Explanatory } \\
\text { variable }\end{array}$ & EDF & $\begin{array}{c}\text { Ref } \\
\mathbf{d f}\end{array}$ & $\begin{array}{c}\text { Chi } \\
\text { Sq }\end{array}$ & $\mathbf{P}$ \\
\hline Date at Site CAD & 1.000 & 1.000 & 1.897 & 0.168 \\
\hline Date at Site LLC & 1.856 & 1.976 & 13.346 & $<\mathbf{0 . 0 0 1}$ \\
\hline Date at Site RHC & 1.919 & 1.993 & 26.218 & $<\mathbf{0 . 0 0 1}$ \\
\hline Date at Site TRE & 1.910 & 1.992 & 38.350 & $<\mathbf{0 . 0 0 1}$ \\
\hline Sun at Site CAD & 1.791 & 1.955 & 5.265 & 0.097 \\
\hline Sun at Site LLC & 1.214 & 1.378 & 0.577 & 0.482 \\
\hline Sun at Site RHC & 1.000 & 1.000 & 2.299 & 0.130 \\
\hline Sun at Site TRE & 1.631 & 1.863 & 10.022 & $\mathbf{0 . 0 1 5}$ \\
\hline Tmean at Site CAD & 1.836 & 1.971 & 6.914 & $\mathbf{0 . 0 4 6}$ \\
\hline Tmean at Site LLC & 1.900 & 1.988 & 8.327 & $\mathbf{0 . 0 2 1}$ \\
\hline Tmean at Site RHC & 1.000 & 1.000 & 0.001 & 0.979 \\
\hline Tmean at Site TRE & 1.000 & 1.000 & 0.433 & 0.511 \\
\hline Ln(Rain) at all Sites & 1.938 & 1.995 & 18.142 & $<\mathbf{0 . 0 0 1}$ \\
\hline
\end{tabular}

The statistically significant results in table 2 are shown as plots in figures $2-5$. Hoverfly abundance increased with ordinal date at three sites (LLC, RHC and TRE) (figure 2). At RHC and TRE, the results showed the abundance increasing rapidly at the end of the sampling period, with the increase beginning at about ordinal date $200-210$ (July 17 to July 28 in non-leap years). 


\section{LLC}

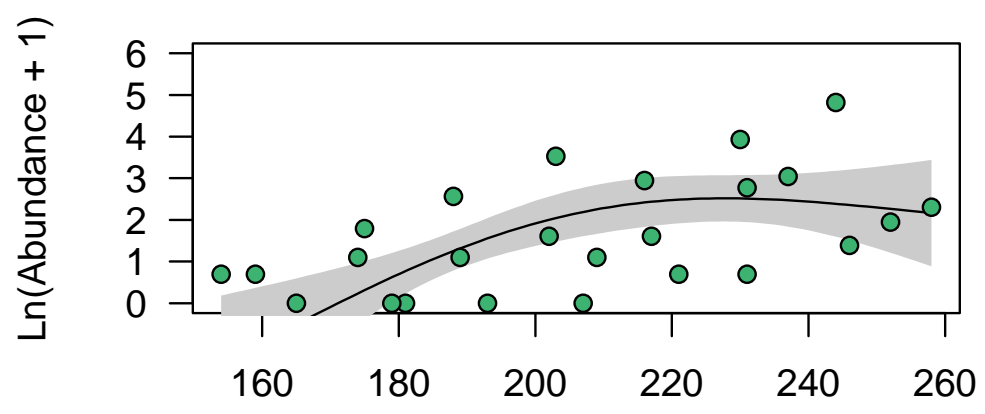

Date

\section{TRE}

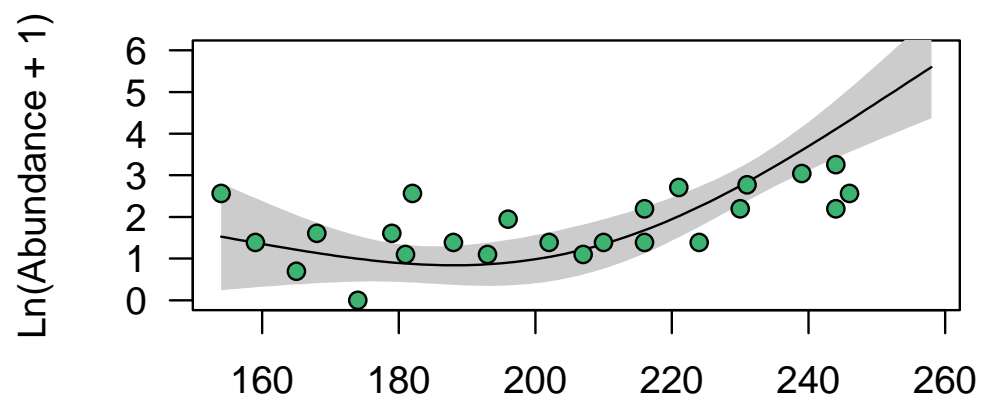

Date

RHC

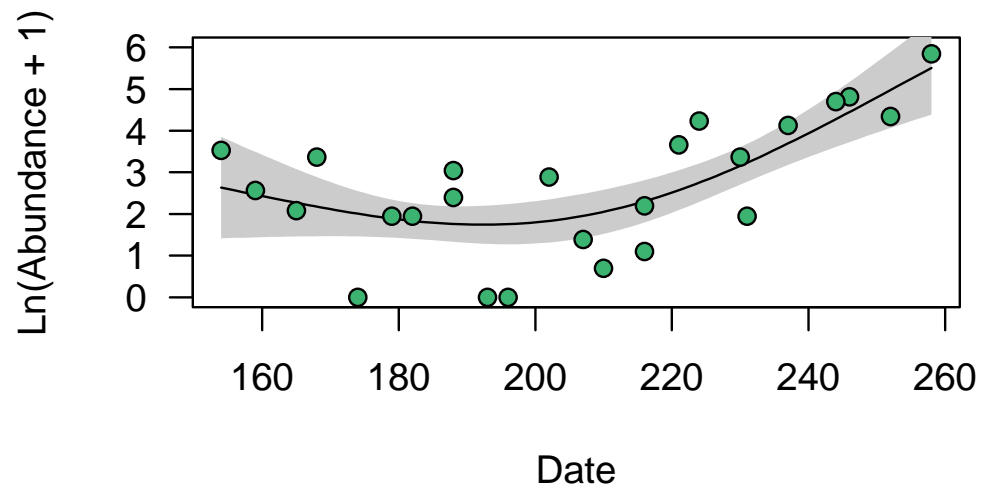

Figure 2: Generalised additive model of effect of ordinal date on hoverfly abundance at three marshy grasslands (LLC, RHC and TRE) in west Wales, UK, between 2011 and 2014. Black line $=$ mean model prediction, grey shading $=$ standard error . 
Insolation (in hours per day) only had a significant effect on hoverfly abundance at site TRE (figure 3). The abundance of hoverflies was unchanged up to approximately 6 hours, but thereafter increased with increasing insolation hours.

\section{TRE}

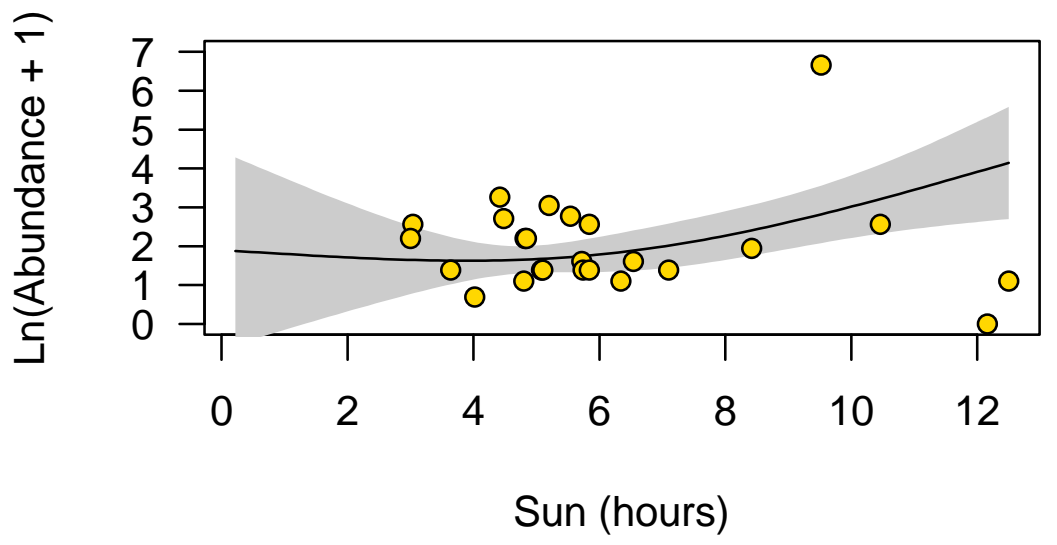

Figure 3: Generalised additive model of effect of insolation ('Sun (hours)') on hoverfly abundance at marshy grassland site TRE in west Wales, UK, between 2011 and 2014. Black line $=$ mean model prediction, grey shading $=$ standard error .

The effect of temperature on hoverfly abundance was significant at two sites, CAD and LLC (figure 4). Here there was a peak in hoverfly abundance at a mean daily temperature of between approximately $14^{\circ} \mathrm{C}$ and $15^{\circ} \mathrm{C}$, with hoverfly abundance reduced at both higher and lower temperatures. 


\section{CAD}

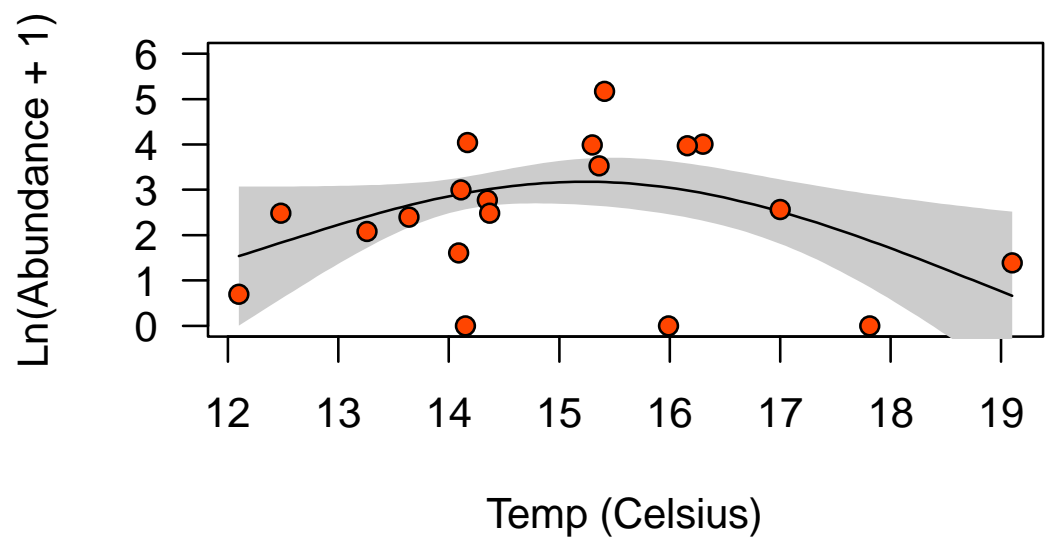

\section{LLC}

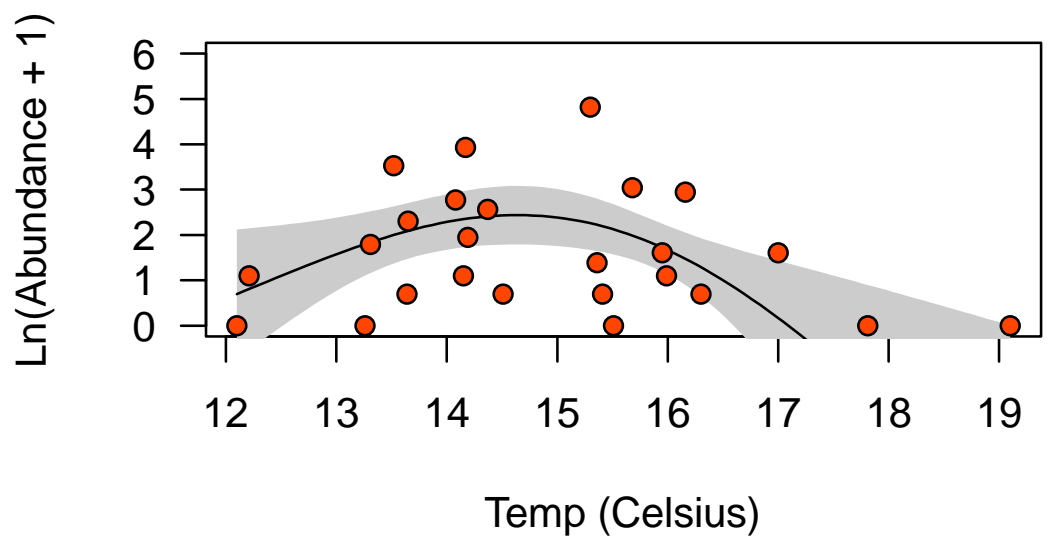

Figure 4: Generalised additive model of effect of temperature on hoverfly abundance at two marshy grassland sites (CAD and LLC) in west Wales, UK, between 2011 and 2014. Black line $=$ mean model prediction, grey shading $=$ standard error.

A similar result was found in the effect of rainfall on hoverfly abundance at all sites combined (figure 5). Hoverfly abundance was greatest at moderate rainfall levels, but was reduced in both high and low rainfall. 


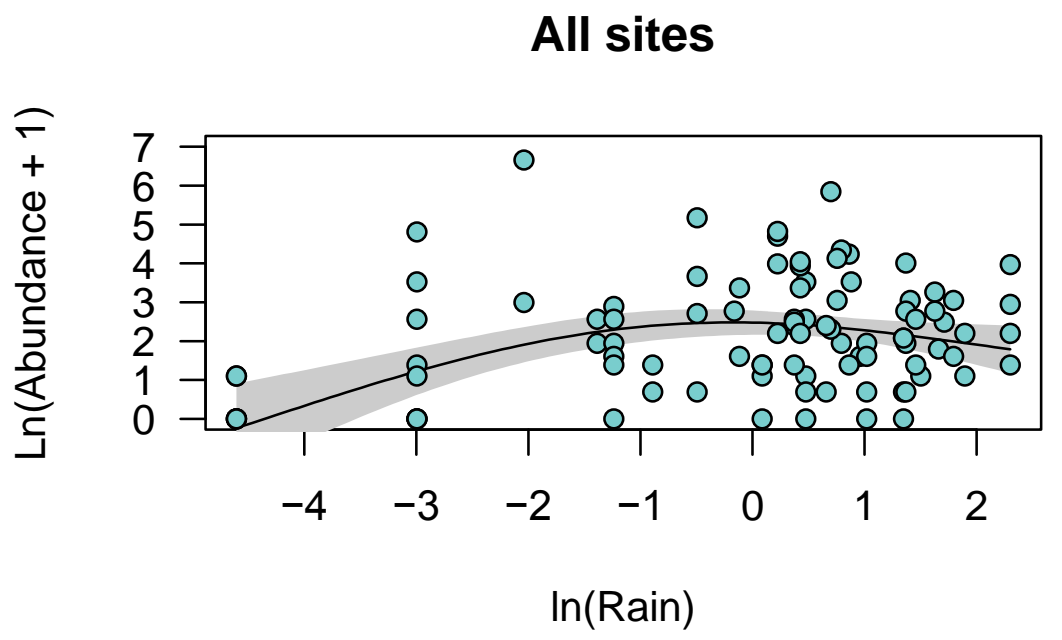

Figure 5: Generalised additive model of effect of mean rainfall $(\mathrm{mm})$ on hoverfly abundance at four marshy grassland sites combined in west Wales, UK, between 2011 and 2014. Black line $=$ mean model prediction, grey shading $=$ standard error .

\section{Effect of Ordinal date and Weather on Hoverfly Species Richness}

The results of the GAM of the effects of ordinal date, mean insolation (hours), mean temperature $\left({ }^{\circ} \mathrm{C}\right)$, and mean rainfall $(\mathrm{mm})$ at each sample on species richness is shown in table 3. There were statistically significant effects of ordinal date on species richness at sites LLC, RHC and TRE; of insolation on species richness at site RHC; of mean daily temperature on species richness at sites LLC and RHC; and of mean rainfall (mm) on species richness at site LLC. The adjusted $\mathrm{R}^{2}$ value was 0.535 , and the model explained $65.7 \%$ of the variance. 
Table 6 Generalised Additive Model $(n=94)$ for the effect on hoverfly species richness of ordinal date ('Date'), insolation ('Sun'), mean daily temperature ('Tmean), and mean rainfall ('Ln(Rain)') at four grassland sites in west Wales, UK. Statistically significant results are shown in bold type face.

\begin{tabular}{|c|c|c|c|c|}
\hline Interaction & EDF & Ref df & Chi Sq & P \\
\hline Date at Site CAD & 1.625 & 1.858 & 4.454 & 0.0630 \\
\hline Date at Site LLC & 1.758 & 1.937 & 8.130 & $\mathbf{0 . 0 2 5 1}$ \\
\hline Date at Site RHC & 1.000 & 1.000 & 9.150 & $\mathbf{0 . 0 0 2 5}$ \\
\hline Date at Site TRE & 1.000 & 1.000 & 16.861 & $<\mathbf{0 . 0 0 1}$ \\
\hline Sun at Site CAD & 1.742 & 1.932 & 2.530 & 0.2986 \\
\hline Sun at Site LLC & 1.773 & 1.945 & 4.468 & 0.0750 \\
\hline Sun at Site RHC & 1.763 & 1.944 & 6.659 & $\mathbf{0 . 0 2 5 2}$ \\
\hline Sun at Site TRE & 1.000 & 1.000 & 0.070 & 0.7908 \\
\hline Tmean at Site CAD & 1.798 & 1.957 & 3.933 & 0.1729 \\
\hline Tmean at Site LLC & 1.897 & 1.988 & 7.876 & $\mathbf{0 . 0 2 1 2}$ \\
\hline Tmean at Site RHC & 1.000 & 1.000 & 4.352 & $\mathbf{0 . 0 3 7 0}$ \\
\hline Tmean at Site TRE & 1.000 & 1.000 & 2.560 & 0.1099 \\
\hline Ln(Rain) at Site CAD & 1.763 & 1.943 & 5.097 & 0.0503 \\
\hline Ln(Rain) at Site LLC & 1.000 & 1.000 & 5.113 & $\mathbf{0 . 0 2 3 8}$ \\
\hline Ln(Rain) at Site RHC & 1.000 & 1.000 & 1.190 & 0.2753 \\
\hline Ln(Rain) at Site TRE & 1.000 & 1.000 & 0.187 & 0.6658 \\
\hline
\end{tabular}

The statistically significant results relating to species-richness in table 3 are shown as plots in figures $6-9$. Hoverfly species richness increased with ordinal date at three sites, LLC, RHC and TRE (figure 6). However, there was a difference in response between sites, with species-richness at site LLC increasing through the sampling period to reach a 
plateau on day 220, similar to hoverfly abundance, whilst sites RHC and TRE showed a relatively consistent increase in species richness throughout the sampling period. 


\section{LLC}

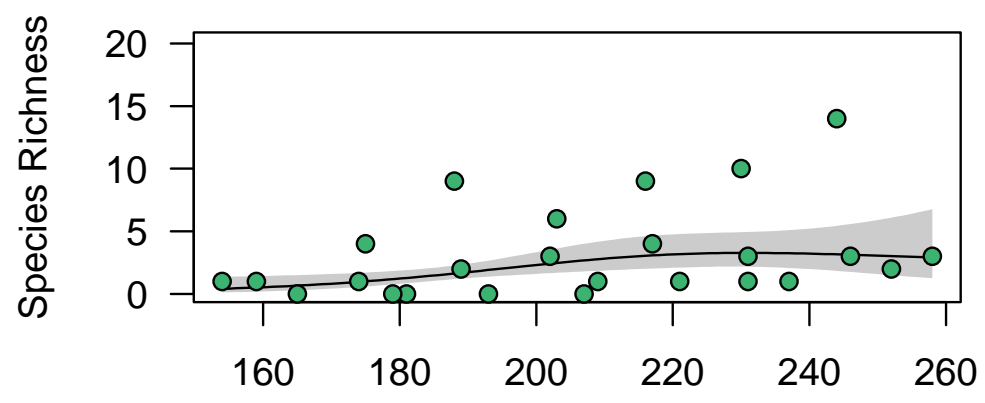

Date

RHC

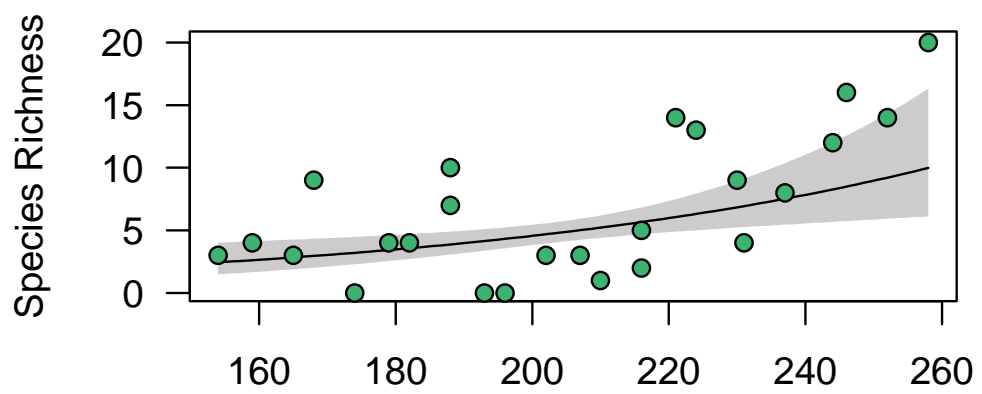

Date

TRE

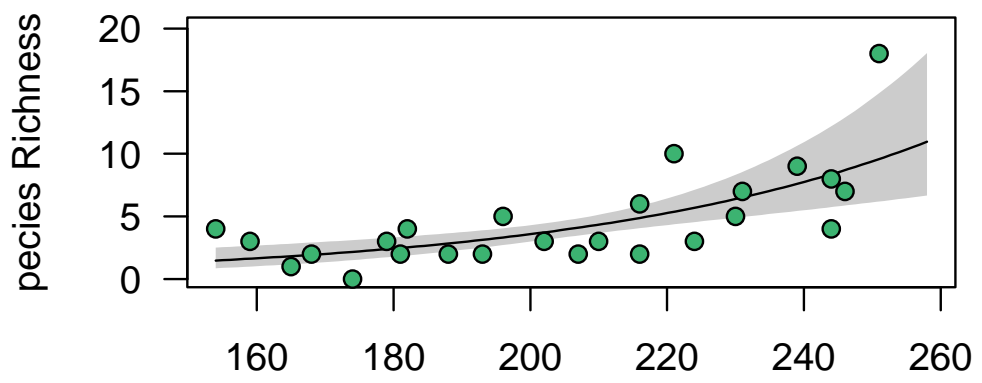

Date

Figure 6: Generalised additive model of effect of ordinal date on hoverfly species richness at three marshy grassland (LLC, RHC and TRE) in west Wales, UK, between 2011 and 2014. Black line $=$ mean model prediction, grey shading $=$ standard error . 
In contrast to hoverfly abundance at site TRE (figure 3), species richness at site RHC (figure 7) showed a declining trend with increased insolation.

\section{RHC}

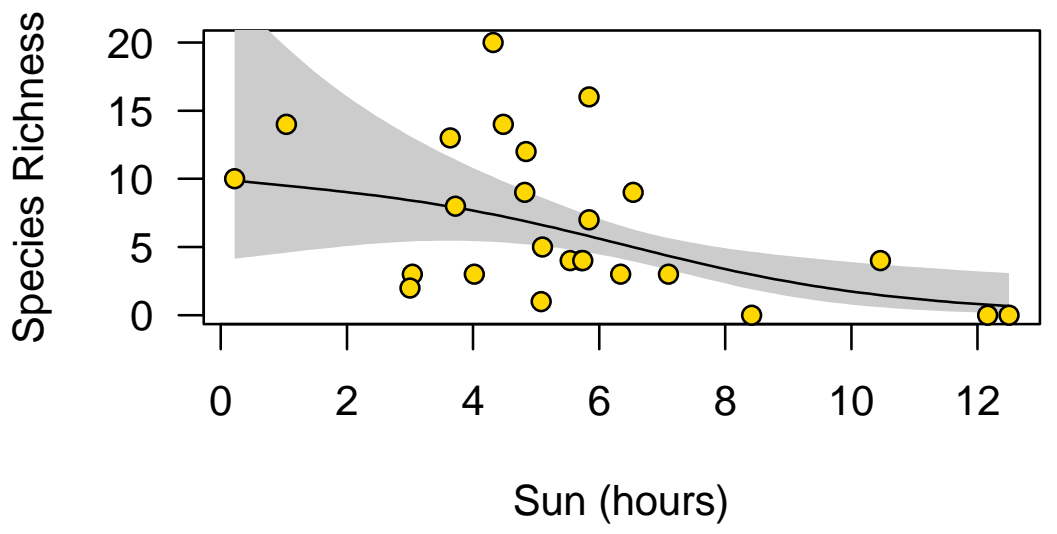

Figure 7: Generalised additive model of effect of insolation ('Sun (hours)') on hoverfly species richness at marshy grassland RHC in west Wales, UK, between 2011 and 2014. Black line $=$ mean model prediction, grey shading $=$ standard error .

Species richness at site LLC (figure 8) showed a similar response to increasing temperature as did hoverfly abundance at sites CAD and LLC (figure 4), with a peak a mean daily temperature of between $14^{\circ} \mathrm{C}$ and $15^{\circ} \mathrm{C}$, and temperatures up to $19^{\circ} \mathrm{C}$ and down to $12^{\circ} \mathrm{C}$ depressing species richness at this site. However, species richness at site RHC (figure 8) declined consistently with increasing temperature. However, it should be noted that a relatively consistent species richness from $12^{\circ} \mathrm{C}$ to approximately $14^{\circ} \mathrm{C}$, with a decline thereafter as temperatures increase is within the standard error of the model. 


\section{LLC}

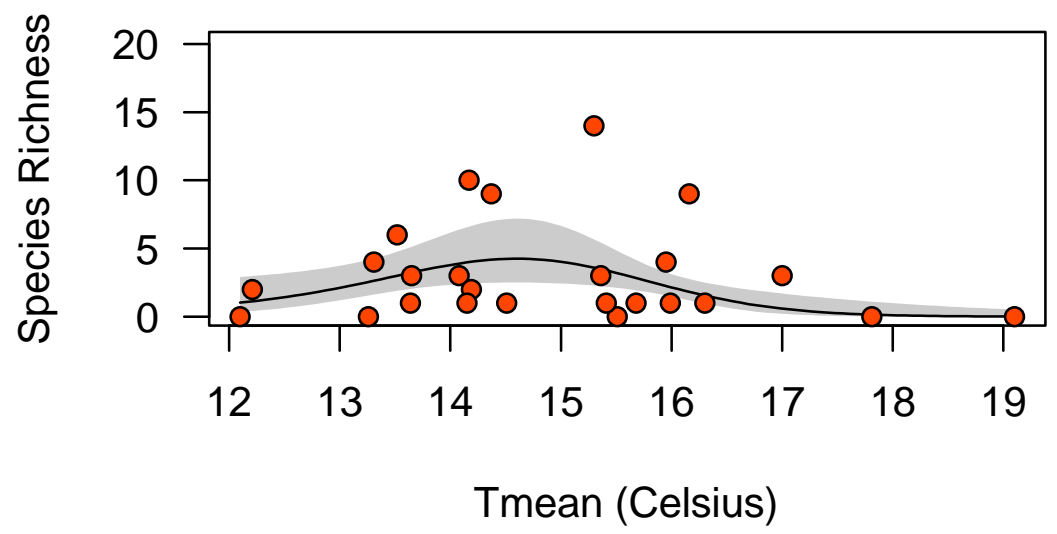

RHC

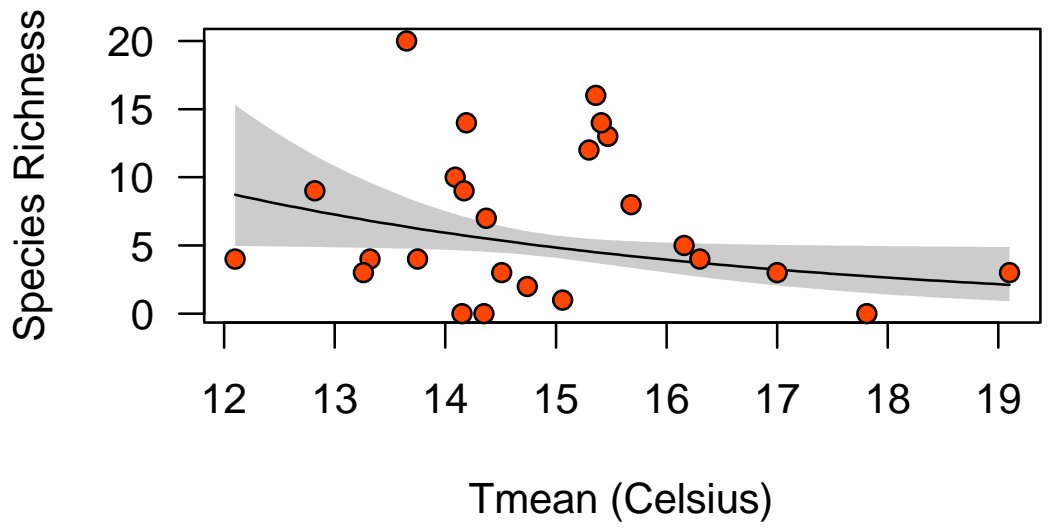

Figure 8: Generalised additive model of effect of mean daily temperature ('Tmean (Celsius)') on hoverfly species richness at two marshy grasslands (LLC and RHC) in west Wales, UK, between 2011 and 2014. Black line = mean model prediction, grey shading = standard error.

Species richness showed a consistent increase with increasing rainfall at site LLC (figure 9), in contrast to the response of hoverfly abundance at all sites (figure 5) 


\section{LLC}

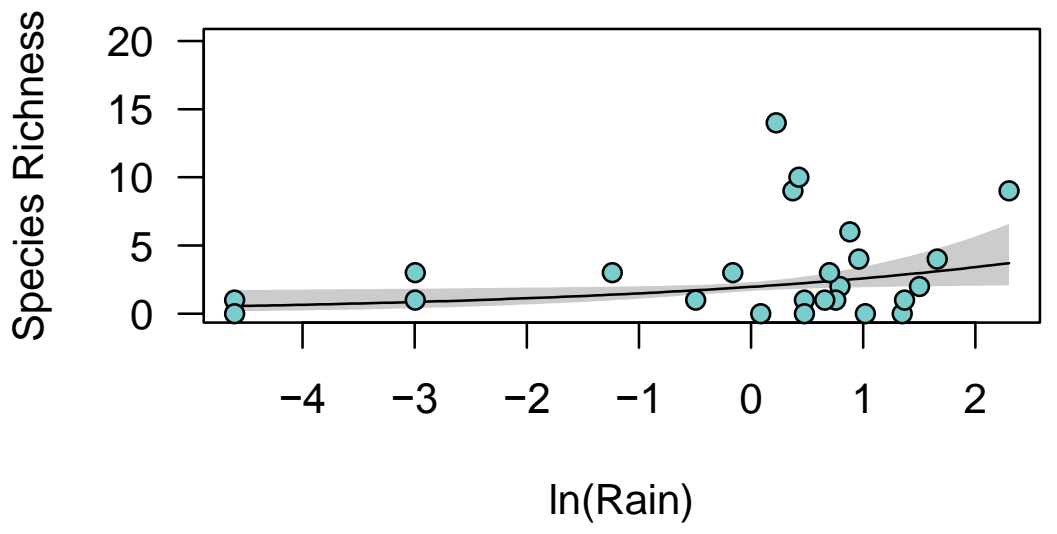

Figure 9: Generalised additive model of effect of $L$ daily rainfall $(\mathrm{mm})$ on hoverfly species richness at marshy grasslands LLC in west Wales, UK, between 2011 and 2014. Black line $=$ mean model prediction, grey shading $=$ standard error .

\section{Discussion}

This study modelled the effects of ordinal date, and the weather metrics mean temperature, rainfall and insolation, on hoverfly abundance and species-richness in fen meadow grasslands. Our results give some indication of how hoverfly populations may respond in future, in the light of climate predictions for the UK (Murphy et al. 2009). The first prediction was that hoverfly abundance and species richness would increase with ordinal date. This was confirmed at three of the four sites. However, our prediction that hoverflies would be less abundant and species rich in conditions of high rainfall and low temperatures, as found in other invertebrate taxa in Britain (Pollard 1988) was not supported. The response of hoverfly populations varied with site, and the response to weather variables was more complex than initially predicted. In particular, the response to mean temperature and rainfall at some sites was non-linear; optimum temperature and rainfall values maximised hoverfly abundance and species-richness, with values of both declining at temperature and rainfall extremes. Murphy et al. (2009) have predicted that, under a medium $\mathrm{CO}_{2}$ emissions scenario, there will be significant increase of between 4.2 ${ }^{\circ} \mathrm{C}$ to $2.5^{\circ} \mathrm{C}$ in summer temperature across much of Britain, with conditions becoming 
drier in southern England, but with little change in precipitation in northern Scotland. The current study suggests that changes in hoverfly abundance and species-richness by hoverflies in response to extremes in both temperature and rainfall could result in changes in hoverfly communities, with possible declines in both abundance and species richness.

The abundance of hoverflies increased with ordinal date at three out of the four study sites, LLC, RHC and TRE (figure 1). The majority of hoverfly individuals recorded in this study (83.5\%) were derived from three taxa - Eristalis species, Helophilus pendulus and Sericomyia silentis. These are polyvoltine species with multiple generations that overlap as the summer adult flight period progresses (Heal 1989). Ball et al. (2011) recorded the numbers of hoverflies of all British species between February and October from 1985 onwards, and found that Eristalis species, H. pendulus and S. silentis species all had peaks in the number of records submitted by observers in late July or August. Adult hoverfly emergence building to a peak over the course of the summer flight period has been recorded in other studies, in both natural habitats and captive populations used for pollination in greenhouses (Pineda \& Marcos-García 2008; Naderloo \& Pashaei Rad 2014). Hoverfly species richness also increased from June to September at sites LLC, RHC and TRE (figure 5). A similar pattern of increasing species-richness as the summer flight season progresses was also found in wet grasslands in Ireland (Carey, Williams \& Gormally 2017). However, although there was a trend for increasing species richness with time at site $\mathrm{CAD}$, it was not significant. The reason for this is unclear. It may be the result of insufficient data, as site CAD was sampled for three years, compared to four at the remaining sites. This further emphasises the value of long-term monitoring to explore changes in hoverfly populations (Dicks et al. 2013; Dicks et al. 2016).

A warming climate may have implications for the phenology of hoverflies. In Britain, Episyrphus balteatus, Eristalis pertinax and E. tenax have emerged earlier in the adult flight period (Graham-Taylor, Stubbs \& Brooke 2009). Species that exhibit increased voltinism, such as Eristalis species, have been shown to more liable to change in their phenology (Hassall, Owen \& Gilbert 2016). Eristalis tenax is also a species that can overwinter as an adult, thus being able to take advantage of warm weather in spring to emerge and breed (Speight 2014; Tomlinson \& Menz 2015). The implications for an earlier flight period are uncertain and, as with other impacts of climate change, require further research (Didham, Basset \& Leather 2010; Dicks et al. 2013). Earlier flight 
periods could cause the peak in hoverfly abundance and species-richness observed in this study (and therefore the peak in the pollination ecosystem service) to take place earlier in the summer flight period. The implications of such a change are uncertain. If there are comparable phenological changes in both pollinator emergence times and plant flowering times, then any mismatch between pollinator populations and the flower resources on which they depend will be minimised (Iler et al. 2013). In such a scenario, the implications of climate change for pollination in some ecosystems may be limited (Forrest 2015). Conversely, increasing ambient temperature has been shown to have contrasting phenological responses in plants and their Dipteran pollinators in arctic ecosystems, significantly reducing the amount of time during the flowering season that plants can be successfully pollinated (Hoye et al. 2013). The consequences for any change in peak hoverfly abundance and species-richness driven by climate change is therefore unclear, for while phenological change in invertebrate taxa have been widely observed (Pozsgai \& Littlewood 2011; Kuhlmann et al. 2012), the implications for plant pollinator interactions are not well understood (Byers 2017).

Hoverflies are often anecdotally reported as being more frequent in periods of high insolation (Ball \& Morris 2013) but, in contrast to the implications of rising temperatures, the effect of increasing insolation as weather patterns change for any guild of pollinators has received very little attention. For example, Forrest (2017), in her review of the impacts of climate change on pollinators, discussed only summer and winter temperature, and reductions in snowpack. Our study found that hoverflies responded to insolation in contradictory ways, with increasing abundance with increasing insolation at site TRE, but declining species richness with increasing insolation at site RHC. That significant relationships in this study between insolation and either hoverfly abundance or species richness were limited to these two examples might suggest that the impact of this weather metric is less than either mean temperature or rainfall. However, increased insolation can have considerable effects on the microclimate experienced by pollinators, by increasing the temperature in flowers above the ambient temperature (Kevan 1975). This has been shown to overheat small bee species, leading to behavioural changes to increase cooling (Corbet \& Huang 2016). Although contrasting responses to overheating have been noted in hoverflies, depending on body size (Gilbert 1984; Gilbert 1985), there has been 
relatively little study of the direct effects of insolation on hoverfly behaviour. More extensive study is required before its importance can be dismissed.

The response of hoverflies to mean daily temperature in this study showed that there was peak abundance in hoverflies between $14.5^{\circ} \mathrm{C}$ and $15.5^{\circ} \mathrm{C}$ at two sites (CAD and LLC), with a decline in hoverfly abundance observed both above and below this range. Species richness was also at a maximum between $14^{\circ} \mathrm{C}$ and $15^{\circ} \mathrm{C}$ at site LLC, but declined with increasing temperature at RHC. Hoverflies are generally associated warm dry conditions, as are other insect species in Britain (Pollard 1988). However, variation in air temperature presents challenges for adult hoverfly thermoregulation, to which they can respond both behaviourally and physiologically. In cool conditions, hoverflies may enter torpor, during which they cease foraging (Hart \& Bale 1997; Hondelmann \& Poehling 2007), or by vibrating wing muscles, to elevate body temperature (Heinrich \& Pantle 1975). Conversely, high temperatures can cause an insect's body temperature to rise above the limit for flight. In such situations, some hoverfly species can lose heat by the evaporation of water through the exoskeleton, which can be permeable in Eristalis species (Bressin \& Willmer 2000). Some Diptera species may also adopt body positions that maximise cooling (Morgan \& Shelly 1988). However, as with cooler conditions, the primary response to high temperatures is to enter torpor. Hoverflies can become inactive at temperatures above $21^{\circ} \mathrm{C}$ (Gilbert 1985). In these conditions, hoverflies stop heat producing activities such as foraging and lekking (Heinrich \& Pantle 1975). Thus, although hoverflies can respond to suboptimal temperatures with behavioural and physiological adaptations, hoverfly foraging is likely to be reduced in such conditions (D'Amen et al. 2013), which could lead to the reduction in abundance seen in this study.

In addition to the behavioural and physiological changes noted above, the response to temperature variation may also vary between hoverfly species, depending on their morphology. Larger insects are better able to elevate their body temperature than smaller species (Bishop \& Armbruster 1999; Muniz et al. 2013). In addition to the differing responses to temperature between large and small hoverfly species noted above, smaller hoverfly species tend to be dark in colour, rather than accurate Batesian mimics, as a trade-off which can aid thermoregulation in cool conditions (Taylor, Reader \& Gilbert 2016). Larger hoverfly species can also employ this strategy. Darker morphs of Eristalis hoverflies, that have a greater capability to warm their body temperature in cool weather, 
are known to be more common during the cooler spring months (Holloway 1993; Ottenheim et al. 1999). Thus, differing responses to temperature could be expected between hoverfly species. In this study, the majority of hoverfly individuals recorded came from three taxa with very similar body sizes, and therefore it is not possible to investigate the effect of temperature on hoverfly species of differing body size. Further work is required to investigate how body size in hoverflies influences a species' response to temperature, the potential effect on community composition, and the consequent impact on pollination service delivery.

Hoverfly abundance appears to be at a maximum at moderate levels of rainfall (figure 4), with both high and low rainfall resulting in reduced hoverfly abundance when all sites are considered. Increased rainfall was also significantly related to increased hoverfly species richness at one site (LLC) (figure 8). Hoverflies might be expected to be more frequent in drier conditions (Ball \& Morris 2013), but there may be a number of explanations why moderate levels of rain increase hoverfly abundance. The greater availability of water may allow a greater degree of body cooling by evaporation as described above (Bressin $\&$ Willmer 2000). Higher rainfall may improve the food resources for hoverflies, because plants may be able to maintain a volume of high quality nectar provided they are not experiencing water stress (Petanidou \& Smets 1996). As previously described, $83.5 \%$ hoverflies identified as part of this study came from relatively large bee or wasp mimic species, that have aquatic larvae with long posterior breathing spiracles, and are found in organic-rich water bodies, mud and detritus (Speight 2014). It is possible that drier conditions may reduce local larval habitat availability, and therefore consequently the number of adults recorded in a given area.

Understanding how weather affects pollinator populations is problematic, because weather metrics will interact, sometime to mitigate effects, and sometimes to reinforce them (Hoover et al. 2012). For example, higher rainfall can have implications for the maintenance of hoverfly feeding resources, particularly at higher temperatures. Takkis et al. (2015) showed that the volume of nectar, sugar concentration per flower, and sugar content could all be maintained by two Lamiaceae species at temperatures up to $38^{\circ} \mathrm{C}$, but only in situations where water was not limiting. Conversely, differences in daily minimum and maximum temperatures may also be important, potentially affecting nectar volume (Mu et al. 2015). High temperatures can also reduce the amount of viable pollen 
a plant produces, which is important for hoverfly foraging, since non-viable pollen has a lower protein content (Prasad, Boote \& Allen 2006).

Previous authors have noted the problems inherent in modelling the responses of invertebrate populations, and specifically hoverflies, to climate change, because multiple interacting factors such as land use change and landscape structure (Dormann et al. 2008). Our data has a number of limitations that may make it difficult to extrapolate from the results. Responses by hoverflies to weather conditions can be site specific (Ottenheim \& Nev 1999), which may in part explain why weather metrics had significant effects on hoverfly populations at some sites and not others in this study. Site management was also not under experimental control. This was a particular issue at site LLC, where heavy grazing and poaching removed much of the flower resource, especially in 2013, but a complete relaxation of grazing after April 2014 resulted in a much greater hoverfly abundance and species-richness in that year. Only four sites of one habitat type were used in the study, and the sampling was restricted to between June and September. However, the effect of weather on hoverfly pollination may be different earlier in the adult flight season, from mid-March to May. The weather data also related to the average over a five day period, which may obscure patterns caused by short term weather events, such as heavy showers or exceptionally warm days. Predicting future changes in hoverfly populations as a consequence of climate change from these results also assumes that hoverfly assemblages will be unchanged. However, changes in the species composition of invertebrate populations have already been noted in Britain (Conrad et al. 2004). Hoverfly assemblages are also undergoing change (Keil et al. 2011), as climate change causes new species to arrive, and those on the southern edge of their range to retreat northwards (Kaloveloni et al. 2015). Some hoverfly genera are predicted to have range contractions in both species-richness and abundance (Radenković et al. 2017), whilst the northwards range expansion of one hoverfly Volucella zonaria in Britain has been attributed to warmer conditions (Morris \& Ball 2004). These results from a four-year study highlights the need for long-term data to study how pollinator populations respond to changes in weather patterns, in order to integrate predictions of climate change with pollination ecosystem service provision.

Combining weather information data with data from existing citizen science recording projects may be possible, although ensuring contemporaneous weather and biological 
data could be difficult. Monitoring the threats and pressures on pollinator populations has been noted as a key research gap (Mayer et al. 2011). Public meteorological data sets, like that used in this study, could be integrated with data arising from a national pollinator monitoring scheme (Carvell et al. 2016), to investigate the response of pollinator taxa to weather in a range of habitats. In the meantime, there is evidence that heterogeneous landscapes with varied microclimates and opportunities for pollinator movement at a landscape scale can ameliorate the effects of climate change in bees (Papanikolaou et al. 2017) and butterflies (Curtis \& Isaac 2015). Since many policy interventions for pollinators aim to increase the amount and variety of resources for pollinators (Dicks et al. 2016), focussing on other stressors on pollinator populations would be the best approach until detailed information on the effects of climate change becomes available.

\section{Acknowledgments}

Thanks to the UK Met Office for making weather data available.

\section{References}

Ball, S. \& Morris, R. (2013) Britain's Hoverflies; An introduction to the hoverflies of Britain. . Princeton University Press.

Ball, S., Morris, R., Rotheray, G. \& Watt, K. (2011) Atlas of the Hoverflies af Great Britain (Diptera, Syrphidae). Wallingford,Biological Records Centre

Bishop, J., Jones, H.E., Lukac, M. \& Potts, S.G. (2016) Insect pollination reduces yield loss following heat stress in faba bean (Vicia faba L.). Agriculture, Ecosystems \& Environment, 220, 89-96.

Bishop, J.A. \& Armbruster, W.S. (1999) Thermoregulatory abilities of Alaskan bees: effects of size, phylogeny and ecology. Functional Ecology, 13, 711-724.

Breeze, T.D., Gallai, N., Garibaldi, L.A. \& Li, X.S. (2016) Economic Measures of Pollination Services: Shortcomings and Future Directions. Trends in Ecology and Evolution. 31: 927-939, 
Bressin, S. \& Willmer, P.G. (2000) Estimation of thermal constants: The importance of using equilibrium temperature rather than ambient temperature demonstrated with hoverflies (Diptera, Syrphidae, genus Eristalis). Journal of Experimental Biology, 203, 2511-2517.

Burkle, L.A. \& Knight, T.M. (2012) Shifts in pollinator composition and behavior cause slow interaction accumulation with area in plant-pollinator networks. Ecology, 93, 2329-2335.

Byers, D.L. (2017) Studying plant-pollinator interactions in a changing climate: A review of approaches. Appl Plant Sci, 5 (6) doi: 10.3732/apps.1700012

Carey, J.G.J., Williams, C.D. \& Gormally, M.J. (2017) Spatiotemporal variation of Diptera changes how we evaluate High Nature Value (HNV) wet grasslands. Biodiversity and Conservation 26: 1541. https://doi.org/10.1007/s10531-0171314-Z

Carvell, C., Isaac, N.J.B., Jitlal, M., Peyton, J., Powney, G.D., Roy, D.B., Vanbergen, A.J., O’Connor, R.S., Jones, C.M., Kunin, W.E., Breeze, T.D., Garratt, M.P.D., Potts, S.G., Harvey, M., Ansine, J., Comont, R.F., Lee, P., Edwards, M., Roberts, S.P.M., Morris, R.K.A., Musgrove, A.J., Brereton, T., Hawes, C. \& Roy, H.E. (2016) Design and Testing of a National Pollinator and Pollination Monitoring Framework. Final summary report to the Department for Environment, Food and Rural Affairs (Defra), Scottish Government and Welsh Government: Project WC1101.

Chen, I.C., Hill, J.K., Ohlemüller, R., Roy, D.B. \& Thomas, C.D. (2011) Rapid Range Shifts of Species Associated with High Levels of Climate Warming. Science, 333 1024-1026 DOI: 10.1126/science.1206432

Christie, M. \& Raiment, N. (2012) An economic assessment of the ecosystem service benefits derived from the SSSI biodiversity conservation policy in England and Wales. Ecosystem Services, 1, 70 - 64.

Conrad, K.F., Woiwod, I.P., Parsons, M., Fox, R. \& Warren, M.S. (2004) Long-term population trends in widespread British moths. Journal of Insect Conservation, $\mathbf{8}$, 119-136.

Corbet, S.A. \& Huang, S.Q. (2016) Small bees overheat in sunlit flowers: do they make cooling flights? Ecological Entomology, 41, 344-350. 
Curtis, R.J. \& Isaac, N.J.B. (2015) The effect of temperature and habitat quality on abundance of the Glanville fritillary on the Isle of Wight: implications for conservation management in a warming climate. Journal of Insect Conservation, 19, 217-225.

D'Amen, M., Birtele, D., Zapponi, L. \& Hardersen, S. (2013) Patterns in diurnal cooccurrence in an assemblage of hoverflies (Diptera: Syrphidae). European Journal of Entomology, 110, 649-656.

Dicks, L.V., Abrahams, A., Atkinson, J., Biesmeijer, J., Bourn, N., Brown, C., Brown, M.J.F., Carvell, C., Connolly, C., Cresswell, J.E., Croft, P., Darvill, B., De Zylva, P., Effingham, P., Fountain, M., Goggin, A., Harding, D., Harding, A., Hartfield, C., Heard, M.E., Heathcote, R., Heaver, D., Holland, J., Howe, M., Hughes, B., Huxley, Y., Kunin, W.E., Little, J., Mason, C., Memmott, J., Osborne, J., Pankhurst, T., Paxton, R.J., Pocock, M.J.O., Potts, S.G., Power, E.F., Raine, N.E., Ranelagh, E., Roberts, S., Saunders, R., Smith, K., Smith, R.M., Sutton, P., Tilley, L.A.N., Tinsley, A., Tonhasca, A., Vanbergen, A.J., Webster, S., Wilson, A. \& Sutherland, W.J. (2013) Identifying key knowledge needs for evidence-based conservation of wild insect pollinators: a collaborative cross-sectoral exercise Insect Conservation and Diversity, 6, 435 - 446.

Dicks, L.V., Viana, B., Bommarco, R., Brosi, B., Arizmendi, M.d.C., Cunningham, S.A., Galetto, L., Hill, R., Lopes, A.V., Pires, C., Taki, H. \& Potts, S.G. (2016) Ten policies for pollinators. Science, 354, 975-976 DOI: 10.1126/science.aai9226

Didham, R.K., Basset, Y. \& Leather, S.R. (2010) Research needs in insect conservation and diversity. Insect Conservation and Diversity, 3, 1-4.

Dormann, C.F., Schweiger, O., Arens, P., Augenstein, I., Aviron, S., Bailey, D., Baudry, J., Billeter, R., Bugter, R., Bukacek, R., Burel, F., Cerny, M., De Cock, R., De Blust, G., DeFilippi, R., Diekotter, T., Dirksen, J., Durka, W., Edwards, P.J., Frenzel, M., Hamersky, R., Hendrickx, F., Herzog, F., Klotz, S., Koolstra, B., Lausch, A., Le Coeur, D., Liira, J., Maelfait, J.P., Opdam, P., Roubalova, M., Schermann-Legionnet, A., Schermann, N., Schmidt, T., Smulders, M.J.M., Speelmans, M., Simova, P., Verboom, J., van Wingerden, W. \& Zobel, M. (2008) Prediction uncertainty of environmental change effects on temperate European biodiversity. Ecology Letters, 11, 235-244. 
Forrest, J.R.K. (2015) Plant-pollinator interactions and phenological change: what can we learn about climate impacts from experiments and observations? Oikos, 124, 4 13.

Forrest, J.R.K. (2017) Insect Pollinators and Climate Change. in Global Climate Change and Terrestrial Invertebrates (Johnson, S.N and Jones, T.H. (eds)) 69-91. John Wiley \& Sons, Ltd.

Giannini, T.C., Acosta, A.L., Garofalo, C.A., Saraiva, A.M., Alves-dos-Santos, I. \& Imperatriz-Fonseca, V.L. (2012) Pollination services at risk: Bee habitats will decrease owing to climate change in Brazil. Ecological Modelling, 244, 127-131.

Gilbert, F. (1985) Diurnal activity patterns in hoverflies (Diptera: Syrphidae). Ecological Entomology, 10, 385 - 392.

Gilbert, F.S. (1984) Thermoregulation and the structure of swarms in Syrphus ribesii (Syrphidae). Oikos, 42, 249-255.

Graham-Taylor, L.G., Stubbs, A.E. \& Brooke, M.d.L. (2009) Changes in phenology of hoverflies in a central England garden. Insect Conservation and Diversity, 2, 2935.

Grass, I., Albrecht, J., Jauker, F., Diekötter, T., Warzecha, D., Wolters, V. \& Farwig, N. (2016) Much more than bees-Wildflower plantings support highly diverse flower-visitor communities from complex to structurally simple agricultural landscapes. Agriculture, Ecosystems \& Environment, 225, 45-53.

Hart, A.J. \& Bale, J.S. (1997) Cold tolerance of the aphid predator Episyrphus balteatus (DeGeer) (Diptera, Syrphidae). Physiological Entomology, 22, 332-338.

Hassall, C., Owen, J. \& Gilbert, F. (2016) Phenological shifts in hoverflies (Diptera: Syrphidae): linking measurement and mechanism. Ecography 40: 853-863. doi:10.1111/ecog.02623/

Heal, J.R. (1989) Variation and seasonal-changes in hoverfly species - interactions between temperature, age and genotype. Biological Journal of the Linnean Society, 36, 251-269.

Hegland, S.J., Nielsen, A., Lázaro, A., Bjerknes, A.L. \& Totland, Ø. (2009) How does climate warming affect plant-pollinator interactions? Ecology Letters, 12, 184195.

Heinrich, B. \& Pantle, C. (1975) Thermoregulation in Small Flies: Basking and Shivering. The Journal of Experimental Biology, 62: 599-610 
Holloway, G.J. (1993) Phenotypic variation in color patters and seasonal plasticity in Eristalis hoverflies (Diptera, Syrphidae)Phenotypic variation in color patters and seasonal plasticity in Eristalis hoverflies (Diptera, Syrphidae). Ecological Entomology, 18, 209-217.

Hondelmann, P. \& Poehling, H.-M. (2007) Diapause and overwintering of the hoverfly Episyrphus balteatus. Entomologia Experimentalis et Applicata, 124, 189-200.

Hoover, S.E., Ladley, J.J., Shchepetkina, A.A., Tisch, M., Gieseg, S.P. \& Tylianakis, J.M. (2012) Warming, CO2, and nitrogen deposition interactively affect a plantpollinator mutualism. Ecology Letters, 15, 227-234.

Hoye, T.T., Post, E., Schmidt, N.M., Trojelsgaard, K. \& Forchhammer, M.C. (2013) Shorter flowering seasons and declining abundance of flower visitors in a warmer Arctic. Nature Climate Change, 3, 759-763.

Iler, A.M., Inouye, D.W., Høye, T.T., Miller-Rushing, A.J., Burkle, L.A. \& Johnston, E.B. (2013) Maintenance of temporal synchrony between syrphid flies and floral resources despite differential phenological responses to climate. Global Change Biology, 19, 2348-2359.

IPBES (2016) Summary for policymakers of the assessment report of the Intergovernmental Science-Policy Platform on Biodiversity and Ecosystem Services on pollinators, pollination and food production. (eds S.G. Potts, V.L. Imperatriz-Fonseca, H.T. Ngo, J.C. Biesmeijer, T.D. Breeze, L.V. Dicks, L.A. Garibaldi, R. Hill, J. Settele, A.J. Vanbergen, M.A. Aizen, S.A. Cunningham, C. Eardley, B.M. Freitas, N. Gallai, P.G. Kevan, A. Kovács-Hostyánszki, P.K. Kwapong, J. Li, X. Li, D.J. Martins, G. Nates-Parra, J.S. Pettis, R. Rader \& B.F. Viana), pp. 36 pages. Secretariat of the Intergovernmental Science-Policy Platform on Biodiversity and Ecosystem Services, Bonn, Germany.

IPCC (2013) Climate Change 2013: The Physical Science Basis. Contribution of Working Group I to the Fifth Assessment Report of the Intergovernmental Panel on Climate Change. (eds T.F. Stocker, D. Qin, G.-K. Plattner, M. Tignor, S.K. Allen, J. Boschung, A. Nauels, Y. Xia, V. Bex \& P.M. Midgley), pp. 1535. Cambridge University Press, Cambridge United Kingdom and New York, NY, USA,. Jagadish, S.V., Bahuguna, R.N., Djanaguiraman, M., Gamuyao, R., Prasad, P.V. \& Craufurd, P.Q. (2016) Implications of High Temperature and Elevated CO2 on Flowering Time in Plants. Frontiers in Plant Science, 7, 913. 
Jauker, F., Bondarenko, B., Becker, H.C. \& Steffan-Dewenter, I. (2012) Pollination efficiency of wild bees and hoverflies provided to oilseed rape. Agricultural and Forest Entomology, 14, 81-87.

Kaloveloni, A., Tscheulin, T., Vujic, A., Radenkovic, S. \& Petanidou, T. (2015) Winners and losers of climate change for the genus Merodon (Diptera: Syrphidae) across the Balkan Peninsula. Ecological Modelling, 313, 201-211.

Keil, P., Biesmeijer, J.C., Barendregt, A., Reemer, M. \& Kunin, W.E. (2011) Biodiversity change is scale-dependent: an example from Dutch and UK hoverflies (Diptera, Syrphidae). Ecography, 34, 392-401.

Kerr, J.T., Pindar, A., Galpern, P., Packer, L., Potts, S.G., Roberts, S.M., Rasmont, P., Schweiger, O., Colla, S.R., Richardson, L.L., Wagner, D.L., Gall, L.F., Sikes, D.S. \& Pantoja, A. (2015) Climate change impacts on bumblebees converge across continents. Science, 349, 177-180 DOI: 10.1126/science.aaa7031

Kevan, P.G. (1975) Sun-Tracking Solar Furnaces in High Arctic Flowers: Significance for Pollination and Insects. Science, 189, 723-726 DOI:

10.1126/science.189.4204.723.

Koti, S., Reddy, K.R., Reddy, V.R., Kakani, V.G. \& Zhao, D. (2005) Interactive effects of carbon dioxide, temperature, and ultraviolet-B radiation on soybean (Glycine max L.) flower and pollen morphology, pollen production, germination, and tube lengths. Journal of Experimental Botany, 56, 725-736.

Kuhlmann, M., Guo, D., Veldtman, R. \& Donaldson, J. (2012) Consequences of warming up a hotspot: species range shifts within a centre of bee diversity. Diversity and Distributions, 18, 885-897.

Laubertie, E.A., Wratten, S.D. \& Sedcole, J.R. (2006) The role of odour and visual cues in the pan-trap catching of hoverflies (Diptera : Syrphidae). Annals of Applied Biology, 148, 173-178.

Le Conte, Y. \& Navajas, M. (2008) Climate change: impact on honey bee populations and diseases. Revue Scientifique Et Technique-Office International Des Epizooties, 27, 499-510.

Liu, Y., Mu, J., Niklas, K.J., Li, G. \& Sun, S. (2012) Global warming reduces plant reproductive output for temperate multi-inflorescence species on the Tibetan plateau. New Phytologist, 195, 427-436. 
Lucas, A., Bull, J.C., de Vere, N., Neyland, P.J. \& Forman, D.W. (2017) Flower resource and land management drives hoverfly communities and bee abundance in seminatural and agricultural grasslands. Ecology and Evolution 1 - 14 DOI: 10.1002/ece3.3303

Mayer, C., Adler, L., Armbruster, S., Dafni, A., Eardley, C., Huang, S., Kevan, P.G., Ollerton, J., Packer, L., Ssymank, A., Stout, J.C. \& Potts, S.G. (2011) Pollination ecology in the the 21st century: key questions for future research. Journal of Pollination Ecology, 3, 8 - 23.

Mayes, J. (2013) Regional weather and climates of the British Isles - Part 5: Wales. Weather, 68, 227-232.

McLeod, C.R., Yeo, M., Brown, A.E., Burn, A.J., Hopkins, J.J. \& Way, S.F.e. (2009) The Habitats Directive: selection of Special Areas of Conservation in the UK. Joint Nature Conservation Committee, Peterborough.

Memmott, J., Craze, P.G., Waser, N.M. \& Price, M.V. (2007) Global warming and the disruption of plant-pollinator interactions. Ecology Letters, 10, 710-717.

Miller-Struttmann, N.E., Geib, J.C., Franklin, J.D., Kevan, P.G., Holdo, R.M., EbertMay, D., Lynn, A.M., Kettenbach, J.A., Hedrick, E. \& Galen, C. (2015) Functional mismatch in a bumble bee pollination mutualism under climate change. Science, 349, 1541-1544.

Morgan, K.R. \& Shelly, T.E. (1988) Body temperature regulation in desert robber flies (Diptera: Asilidae). Ecological Entomology, 13, 419-428.

Morris, R.K.A. \& Ball, S.G. (2004) Sixty years of Volucella zonaria (Poda) (Diptera:Syrphidae) in Britain. British Journal of Entomology and Natural History, 17, 217 - 227.

Mu, J.P., Peng, Y.H., Xi, X.Q., Wu, X.W., Li, G.Y., Niklas, K.J. \& Sun, S.C. (2015) Artificial asymmetric warming reduces nectar yield in a Tibetan alpine species of Asteraceae. Annals of Botany, 116, 899-906.

Muniz, J.M., Pereira, A.L.C., Valim, J.O.S. \& Campos, W.G. (2013) Patterns and mechanisms of temporal resource partitioning among bee species visiting basil (Ocimum basilicum) flowers. Arthropod-Plant Interactions, 7, 491-502.

Murphy, J.M., Sexton, D.M.H., Jenkins, G.J., Boorman, P.M., Booth, B.B.B., Brown, C.C., Clark, R.T., Collins, M., Harris, G.R., Kendon, E.J., Betts, R.A., Brown, 
S.J., Howard, T.P., Humphrey, K.A., McCarthy, M.P., McDonald, R.E., Stephens, A., Wallace, C., Warren, R., Wilby, R. \& Wood, R.A. (2009) UK Climate Projections Science Report: Climate change projections., pp. 190. Met Office Hadley Centre, Exeter.

Naderloo, M. \& Pashaei Rad, S. (2014) Diversity of hoverfly (Diptera: Syrphidae) communities in different months in eastern part of Zanjan province, Iran. Zoology and Ecology, 24, 261-265.

Ollerton, J., Winfree, R. \& Tarrant, S. (2011) How many flowering plants are pollinated by animals? Oikos, 120, 321-326.

Orford, K.A., Vaughan, I.P. \& Memmott, J. (2015) The forgotten flies: the importance of non-syrphid Diptera as pollinators. Proceedings of the Royal Society B, 282 20142934; DOI: 10.1098/rspb.2014.2934.

Ottenheim, M.M. \& Nev (1999) Annual and diurnal rhythms of Eristalis species (Diptera : Syrphidae). Proceedings of Experimental and Applied Biology 11169 - 174

Ottenheim, M.M., Wertheim, B., Holloway, G.J. \& Brakefield, P.M. (1999) Survival of colour-polymorphic Eristalis arbustorum hoverflies in semi-field conditions. Functional Ecology, 13, 72-77.

Papanikolaou, A.D., Kuhn, I., Frenzel, M. \& Schweiger, O. (2017) Landscape heterogeneity enhances stability of wild bee abundance under highly varying temperature, but not under highly varying precipitation. Landscape Ecology, 32, 581-593.

Petanidou, T. \& Smets, E. (1996) Does temperature stress induce nectar secretion in Mediterranean plants? New Phytologist, 133, 513-518.

Pineda, A. \& Marcos-García, M.Á. (2008) Seasonal Abundance of Aphidophagous Hoverflies (Diptera: Syrphidae) and Their Population Levels In and Outside Mediterranean Sweet Pepper Greenhouses. Annals of the Entomological Society of America, 101, 384-391.

Polce, C., Termansen, M., Aguirre-Gutierrez, J., Boatman, N.D., Budge, G.E., Crowe, A., Garratt, M.P., Pietravalle, S., Potts, S.G., Ramirez, J.A., Somerwill, K.E. \& Biesmeijer, J.C. (2013) Species Distribution Models for Crop Pollination: A Modelling Framework Applied to Great Britain. Plos One, 8(10): e76308. https://doi.org/10.1371/journal.pone.0076308 
Pollard, E. (1988) Temperature, Rainfall and Butterfly Numbers. Journal of Applied Ecology, 25, 819-828.

Pontin, D.R., Wade, M.R., Kehrli, P. \& Wratten, S.D. (2006) Attractiveness of single and multiple species flower patches to beneficial insects in agroecosystems. Annals of Applied Biology, 148, 39-47.

Potts, S., Biesmeijer, J., Kremen, C., Neumann, P., Schweiger, O. \& Kunin, W. (2010) Global pollinator declines: trends, impacts and drivers. Trends in Ecology \& Evolution, 25, 345-353.

Pozsgai, G. \& Littlewood, N.A. (2011) Changes in the phenology of the ground beetle Pterostichus madidus (Fabricius, 1775). Insect Science, 18, 462-472.

Prasad, P.V.V., Boote, K.J. \& Allen, L.H. (2006) Adverse high temperature effects on pollen viability, seed-set, seed yield and harvest index of grain-sorghum [Sorghum bicolor (L.) Moench] are more severe at elevated carbon dioxide due to higher tissue temperatures. Agricultural and Forest Meteorology, 139, 237-251.

R Core Team (2014) R: a language and environment for statistical computing., pp. http://www.R-project.org R Foundation for Statistical Computing, Vienna, Austria.

Radcliffe, D.A.e. (1989) Guidelines for selection of biological SSSIs. Nature Conservancy Council, Peterborough.

Radenković, S., Schweiger, O., Milić, D., Harpke, A. \& Vujić, A. (2017) Living on the edge: Forecasting the trends in abundance and distribution of the largest hoverfly genus (Diptera: Syrphidae) on the Balkan Peninsula under future climate change. Biological Conservation, 212, Part A, 216-229.

Rader, R., Bartomeus, I., Garibaldi, L.A., Garratt, M.P.D., Howlett, B.G., Winfree, R., Cunningham, S.A., Mayfield, M.M., Arthur, A.D., Andersson, G.K.S., Bommarco, R., Brittain, C., Carvalheiro, L.G., Chacoff, N.P., Entling, M.H., Foully, B., Freitas, B.M., Gemmill-Herren, B., Ghazoul, J., Griffin, S.R., Gross, C.L., Herbertsson, L., Herzog, F., Hipólito, J., Jaggar, S., Jauker, F., Klein, A.-M., Kleijn, D., Krishnan, S., Lemos, C.Q., Lindström, S.A.M., Mandelik, Y., Monteiro, V.M., Nelson, W., Nilsson, L., Pattemore, D.E., de O. Pereira, N., Pisanty, G., Potts, S.G., Reemer, M., Rundlöf, M., Sheffield, C.S., Scheper, J., Schüepp, C., Smith, H.G., Stanley, D.A., Stout, J.C., Szentgyörgyi, H., Taki, H., Vergara, C.H., Viana, B.F. \& Woyciechowski, M. (2015) Non-bee insects are 
important contributors to global crop pollination. Proceedings of the National Academy of Sciences, 113, 146 - 151.

Radmacher, S. \& Strohm, E. (2011) Effects of constant and fluctuating temperatures on the development of the solitary bee Osmia bicornis (Hymenoptera: Megachilidae). Apidologie, 42, 711-720.

Rasmont, P. \& Iserbyt, S. (2012) The Bumblebees Scarcity Syndrome: Are heat waves leading to local extinctions of bumblebees (Hymenoptera: Apidae: Bombus)? Annales de la Société entomologique de France (N.S.), 48, 275-280.

Rodwell, J., Pigott, C.D., Ratclliffe, D.A., Malloch, A.J.C., Proctor, M.C.F., Shimwell, D.W., Huntley, J.P., Radford, E., Wigginton, M.J. \& Wilkins, P. (1991) British Plant Communities Volume 2. Mires and heaths. Cambridge University Press, Cambridge.

Roy, D.B. \& Sparks, T.H. (2000) Phenology of British butterflies and climate change. Global Change Biology, 6, 407-416.

Scaven, V.L. \& Rafferty, N.E. (2013) Physiological effects of climate warming on flowering plants and insect pollinators and potential consequences for their interactions. Current Zoology, 59, 418-426.

Schmidt, N.M., Mosbacher, J.B., Nielsen, P.S., Rasmussen, C., Høye, T.T. \& Roslin, T. (2016) An ecological function in crisis? The temporal overlap between plant flowering and pollinator function shrinks as the Arctic warms. Ecography 39: 1250-1252. doi:10.1111/ecog.02261

Schurch, R., Accleton, C. \& Field, J. (2016) Consequences of a warming climate for social organisation in sweat bees. Behavioral Ecology and Sociobiology, 70, 1131-1139.

Sgolastra, F., Kemp, W.P., Buckner, J.S., Pitts-Singer, T.L., Maini, S. \& Bosch, J. (2011) The long summer: pre-wintering temperatures affect metabolic expenditure and winter survival in a solitary bee. Journal of Insect Physiology, 57, 1651-1659.

Smith, M.R., Singh, G.M., Mozzaffarian, D. \& Myers, S.S. (2015) Effects of decreases of animal pollinators on human nutrition and global health: a modelling analysis. The Lancet, 386, 1964 - 1972.

Sparks, T.H., Jeffree, E.P. \& Jeffree, C.E. (2000) An examination of the relationship between flowering times and temperature at the national scale using long-term 
phenological records from the UK. International Journal of Biometeorology, 44, 82-87.

Speight, M.C.D. (2014) Species accounts of European Syrphidae (Diptera), 2014. Syrph the Net publications, Dublin.

Stubbs, A.E. \& Falk, S.J. (2002) British Hoverflies. An illustrated identification guide. BENHS, Reading.

Takkis, K., Tscheulin, T., Tsalkatis, P. \& Petanidou, T. (2015) Climate change reduces nectar secretion in two common Mediterranean plants. AoB PLANTS, 15;7. doi: 10.1093/aobpla/plv111.

Taylor, C.H., Reader, T. \& Gilbert, F. (2016) Why many Batesian mimics are inaccurate: evidence from hoverfly colour patterns. Proceedings of the Royal Society B: Biological Sciences, 283 20161585; DOI: 10.1098/rspb.2016.1585.

Thomas, C.D., Cameron, A., Green, R.E., Bakkenes, M., Beaumont, L.J., Collingham, Y.C., Erasmus, B.F.N., de Siqueira, M.F., Grainger, A., Hannah, L., Hughes, L., Huntley, B., van Jaarsveld, A.S., Midgley, G.F., Miles, L., Ortega-Huerta, M.A., Peterson, A.T., Phillips, O.L. \& Williams, S.E. (2004) Extinction risk from climate change. Nature, 427, 145-148.

Tomlinson, S. \& Menz, M.H.M. (2015) Does metabolic rate and evaporative water loss reflect differences in migratory strategy in sexually dimorphic hoverflies? Comparative Biochemistry and Physiology a-Molecular \& Integrative Physiology, 190, 61-67.

Urban, M.C. (2015) Accelerating extinction risk from climate change. Science, 348, 571. Walther, G.R., Post, E., Convey, P., Menzel, A., Parmesan, C., Beebee, T.J.C., Fromentin, J.M., Hoegh-Guldberg, O. \& Bairlein, F. (2002) Ecological responses to recent climate change. Nature, 416, 389-395.

Wheater, C.P. \& Cook, P.A. (2003) Studying Invertebrates. The Richmond Publishing Company, Slough.

Willmer, P.G. (1983) Thermal constraints on activity patterns in nectar-feeding insects. Ecological Entomology, 8, 455-469. 


\section{Chapter 4}

\section{A reference library of CO1 DNA barcodes for British}

\section{Syrphidae}

Andrew Lucas, Col R. Ford, Dan W. Forman, Carolyn Greig, Penelope J. Neyland, Natasha de Vere

Andrew Lucas conceived the study, undertook fieldwork, DNA extraction and sequencing, and lead the writing of the manuscript. Col Ford undertook analysis of sequence data and figure preparation.

Carolyn Greig helped to devise the DNA extraction and amplification protocol, and provided training in molecular techniques. Dan Forman and Penny Neyland advised on the drafting of the manuscript.

Natasha de Vere helped to conceive the study, advised on data analysis, and drafting the manuscript. 


\section{Summary}

DNA barcoding based on partial cytochrome $c$ oxidase subunit 1 (COI) sequences has been demonstrated to be an effective method of identifying many invertebrate species, including hoverflies (Syrphidae). To assist the use of DNA barcoding as a monitoring tool in Britain, we constructed a reference data set of 2853 individual sequences of 210 species. Some 82 species (256 sequences) were barcoded for this study from specimens collected in Britain. The remainder were drawn from publicly available sequences of species collected elsewhere that occur in Britain. The ability of sequences to identify species was determined using the Kimura 2-parameter (K2P) distance, and a nearest neighbour joining tree was constructed. Sequences showed low mean K2P divergence within species, with only one (Cheilosia proxima, 3.6\%) having a mean distance greater than 3\%. Five genera had a mean interspecific distance less than 3\%. Some 110 species pairs ( $0.5 \%$ of total potential pairs) had a mean divergence less than $3 \%$, indicating low discrimination between species, particularly in the genera Eupeodes and Sphaerophoria. Of the 86 species that contribute $90 \%$ of all hoverfly species records in Britain, barcodes are available for 84 , suggesting this library is a practical tool for species recording and identification in most situations in Britain. However, 77 species lack barcodes, and 36 species are represented by a single specimen. Therefore, further work is required to complete a barcode reference library of British Syrphidae. 


\section{$\underline{\text { Introduction }}$}

Understanding species diversity is one of the key challenges in biology (Hutchinson 1959). The ability to identify an organism is critical to the conservation of biodiversity, but in many situations this may be limited by access to suitable taxonomic expertise (Tautz et al. 2003), or because the material available (e.g. fragments recovered from faeces) is insufficient for traditional morphological approaches (Zeale et al. 2011).

DNA barcodes, derived from short standardised sections of a species' genome offer a solution to the problem of limited taxonomic expertise (Godfray 2007). A 650-bp fragment of the 5'-end of the mitochondrial COI gene is now the established barcode region for animals (Hebert et al. 2003), with additional markers being used for greater taxonomic and phylogenetic investigation (Mengual, Ståhls \& Rojo 2008). The principle, which assumes that variation between species in this genetic region exceeds the intraspecific variation (the 'barcode gap'), has been shown to be effective in discriminating species in a number of invertebrate groups by matching an unknown sequence to those in a reference library (deWaard, Hebert \& Humble 2011; Park et al. 2011; Iftikhar et al. 2016). There is now a considerable world-wide effort to compile global DNA barcode libraries, which will eventually allow the identification of all metazoan species (Hajibabaei et al. 2005). These libraries of sequences require specimen collection data, images and the details of the location of an associated voucher specimen, in a publicly accessible repository, the Barcode of Life Datasystem (BOLD) (www.boldsystems.org) (Ratnasingham and Hebert 2007). Once DNA barcode libraries are publicly available, it becomes practical to make assessments of species diversity, particularly of invertebrates, from bulk mixed-species samples by means of next generation sequencing using DNA metabarcoding (Taberlet et al. 2012; Yu et al. 2012; Creer et al. 2016). Such techniques can also be applied to mixed samples collected as part of citizen science projects (Geiger et al. 2016).

There are 282 species of British hoverflies (Syrphidae) (Chandler 2017), with new species added to the British list at a rate of about one per year (Ball \& Morris 2013), and over 6000 named species worldwide (Wardhaugh 2015). Adult hoverflies feed almost exclusively on nectar and pollen (Ssymank \& Gilbert 1993; Radisic et al. 2001; Rotheray \& Gilbert 2011), making these insects important pollinators of wild plant species and 
many crops (Ambrosino et al. 2006; Jauker \& Wolters 2008; Prodorutti \& Frilli 2008). Pollination by insects is a key regulating ecosystem service (Nabhan \& Buchmann 1997), and there is now considerable evidence that wild bee species, together with hoverflies, are the primary pollinators of many crops, rather than domestic honey bees Apis mellifera (Ollerton et al. 2012; Blitzer et al. 2016). Consequently, monitoring of pollinator populations is important to ensure that this pollination service is not compromised (Casey et al. 2015; Carvell et al. 2016; Dicks et al. 2016). However, although many hoverflies are known for their Batesian mimicry of bees and wasps (Edmunds \& Reader 2014) and can readily be identified from specimens or even photographs, others are relatively nondescript and present a considerable identification challenge as adults (Stubbs \& Falk 2002). Moreover, hoverfly larvae have diverse life strategies including carnivorous, saprophagous and herbivorous species. Amongst carnivorous species, some have aphidophagous larvae that can be effective biological control agents (Ramsden et al. 2016). However, identification of this life stage is difficult, with most species unable to be identified beyond genus (Rotheray 1993). For a number of British species the larval stage remains unknown (Ball et al. 2011).

Molecular techniques including the use of the COI barcode region have been applied successfully in the wider study of hoverfly taxonomy (Stahls et al. 2003; Mengual, Stahls \& Rojo 2008; Skevington \& Thompson 2012; Vujić et al. 2013; Jordaens et al. 2015), and in the discovery of new hoverfly species in Europe (Claussen \& Stahls 2007; Stahls et al. 2009; Marcos-García et al. 2011; Radenkovic et al. 2011). However, although a number of regional barcode libraries have been compiled for a range of invertebrate taxonomic groups in Europe, including Orthoptera (Hawlitschek et al. 2016), Coleoptera (Hendrich et al. 2015; Raupach et al. 2016), Hemiptera (Raupach et al. 2014) and some Diptera (Pohjoismaki, Kahanpaa \& Mutanen 2016; Morinière et al. 2017), there has been no barcode library published for the hoverflies of Britain.

Here, we present the first compilation of DNA barcodes for Syrphidae species recorded in Britain. We compiled a reference library of 82 species in 40 genera from specimens collected in Britain, representing $29 \%$ of the British hoverfly fauna. This was combined with existing global published sequences for species recorded in the Britain, to make a library covering 210 species representing 74\% of British species. Using the Kimura 2 parameter, we investigated intraspecies and interspecies barcode distances, to establish 
the ability of COI barcodes to discriminate hoverfly species, and compared the species where barcodes are available with the 86 species that make up $90 \%$ of individual British hoverfly records. The results give some indication of the effectiveness of the COI barcode in discriminating British hoverfly species, the practicality of using DNA barcodes as part of a monitoring programme, and genera where identification to species level remains problematic.

\section{Methods}

\section{Field Collection and metadata compilation}

All samples were obtained from specimens caught in south Wales and southern England between 2011 and 2016. It had been planned to utilise preserved material from museum collections. However an initial test with 10 Eristalis specimens, captured from 1987 to 1995 in the collection of the National Museum of Wales, Cardiff, failed to yield COI DNA fragments of the required length. The use by entomologists of ethyl acetate as a killing agent is a likely explanation (Dillon, Austin \& Bartowsky 1996; Gilbert et al. 2007). Since many species are represented in the collection by single specimens, damaging them with no guarantee of successful amplification could not be justified. Therefore, only live caught material preserved in ethanol or by freezing was used. Some had been caught in pan traps as part of another study, and had been stored in $70 \%$ ethanol (Lucas et al. 2017). Other specimens were caught specifically for DNA extraction. These were placed in a sterilised $1.5 \mathrm{ml}$ Eppendorf in the field, and subsequently killed by freezing at $-20^{\circ} \mathrm{C}$. They were then be identified, pinned, and placed in a collection for subsequent use.

A number of specimens were also provided by volunteers, who were supplied with sterilised Eppendorf tubes, and asked to use one insect per tube, and store them in a suitable freezer. They were then posted to the authors for confirmation of identification, and placed in the collection. Specimens were identified morphologically using Stubbs and Falk (2002). All identifications were undertaken by the lead author, with results subsequently confirmed by staff at the National Museum of Wales, Cardiff (NMW). All specimens used for this study will subsequently be stored at NMW. 
Following BOLD guidelines, a standard project ('Welsh Syrphidae SUAL') was created for all successfully sequenced and subsequently validated specimens. Each specimen had metadata associated with it (see table 1). The number of specimens per species sequenced ranged from one (12 species 15\% of total) to eight (Pipiza noctiluca) (see table 2). 
Table 7 Metadata associated with each hoverfly specimen

\begin{tabular}{|c|c|}
\hline Metadata & Description \\
\hline Process ID & Unique DNA sample identifier (provided by BOLD) \\
\hline Sample ID & $\begin{array}{l}\text { Unique identifier for the specimen, and tissue sample used for the } \\
\text { analysis. This was 'SUAL' followed by a four figure number. }\end{array}$ \\
\hline Institution Storing & $\begin{array}{l}\text { All specimens were deposited with the National Museum of Wales, } \\
\text { Cardiff }\end{array}$ \\
\hline Phylum Name & Phylum Name (Arthropoda) \\
\hline Class name & Class Name (Insecta) \\
\hline Order Name & Order Name (Diptera) \\
\hline Family Name & Family Name (Syrphidae) \\
\hline Subfamily Name & Subfamily Name \\
\hline Genus Name & Genus Name \\
\hline Species Name & Species Name \\
\hline Identifier & Person providing taxonomic identification \\
\hline Identification Method & 'Morphological' in all cases \\
\hline Sex & Sex of specimen determined morphologically \\
\hline Life Stage & 'Adult' in all cases \\
\hline Tissue Descriptor & 'Leg' in all cases \\
\hline Collector name & Person collecting insect \\
\hline Location & $\begin{array}{l}\text { Name of site (e.g. farm name, or name of nature reserve, nearest } \\
\text { village etc.), county, and country. }\end{array}$ \\
\hline Latitude/Longitude Grid Reference & $\begin{array}{l}\text { Location of collection site. Minimum required was a standard UK } \\
\text { two letter and four figure grid reference (i.e. a } 1 \mathrm{~km} \text { square), } \\
\text { subsequently converted to latitude and longitude. }\end{array}$ \\
\hline Collection Date & Collection Date \\
\hline
\end{tabular}


All DNA analysis was undertaken at Swansea University. DNA extraction was performed using either a single leg (larger species) or two to three legs (smaller species). Generally, the rear legs were used for extraction, except for species where the rear leg is critical to morphological identification. Extractions were carried out using the DNeasy Blood \& Tissue Kit (Hilden GmbH, Germany) following the manufacturer's instructions; samples were resuspended in $50 \mu$ l ultra-pure water.

DNA was amplified using a polymerase chain reaction (PCR), using the standard animal target barcode marker, the 5' region of COI (Hebert et al. 2003), using the forward primer LCO1490 (5' - GGTCAACAAATCATAAAGATATTGG - 3') and reverse primer HCO2198 (5' - TAAACTTCAGGGTGACCAAAAAATCA - 3') (Folmer et al. 1994; Radenkovic et al. 2011) .

The PCR was performed in a volume of $20 \mathrm{ul}$ using the following reagents: $10.7 \mu 1$ PCR grade $\mathrm{H}_{2} \mathrm{O}, 3.9 \mu \mathrm{l}$ 10X Taq PCR buffer, $1.9 \mu 125 \mathrm{mM} \mathrm{MgCl}$ solution, $0.1 \mu 110 \mathrm{mM}$ dNTPs, $0.2 \mu 1$ 10mM primer mix, and $0.2 \mu \mathrm{l}$ of $5 \mathrm{U} / \mathrm{ul}$ Taq DNA polymerase. This $17 \mu \mathrm{l}$ mastermix was added to $3 \mu \mathrm{l}$ of sample DNA. The reaction was performed in a thermal cycler using the following conditions: an initial denaturing at $94^{\circ} \mathrm{C}$ for 2 minutes; 5 cycles of 60 seconds at $72^{\circ} \mathrm{C}$ followed by 40 seconds at $45^{\circ} \mathrm{C} ; 35$ cycles of 60 seconds at $72^{\circ} \mathrm{C}$ followed by 40 seconds at $51^{\circ} \mathrm{C} ; 10$ minutes at $72^{\circ} \mathrm{C}$. For each PCR, a negative water control, and a positive control of Diptera DNA extracted from commercially available Calliphora vomitoria maggots, was used.

The products of the PCR reaction were visualised on a $1 \%$ agarose gel to confirm successful amplification. A combined aliquot of sample DNA ( $3 \mu \mathrm{l})$ and loading buffer $(2 \mu \mathrm{l})$ was used with a GeneRuler $1 \mathrm{~kb}$ DNA ladder $(3 \mu \mathrm{l})$ added to each sample row. The gels were run for 30 minutes at $100 \mathrm{~V}$.

Gel images were recorded and used for DNA quantification using Image Lab version 5.1 (C) Bio Rad Laboratories. PCR products were then sequenced in both directions by Eurofins Genomics GmbH (www.eurofinsDNA.com). A $15 \mu$ l sample of each PCR product was provided, normalised to a concentration of $10 \mathrm{ng} / \mu \mathrm{l}$ to comply with Eurofins 
requirements. Sequencing was undertaken using the same primers as the original amplification.

\section{Sequence analysis and data storage}

Sequence trace files were imported into Sequence Scanner Software 2 Version 2.0 (C) Applied Biosystems 2012 (http://www.appliedbiosystems.com) and quality control and trace score reports were generated for each sequence. Sequences with a contiguous read length greater than $500 \mathrm{bp}$ were used for subsequent analysis.

Suitable sequences were then imported into Seq Trace 0.9.0 (@2014 Brian J. Stucky). Forward and reverse sequences for each sample were then aligned, and edited where necessary. Finished sequences were then generated, and exported as a bulk FASTA file of trimmed consensus sequences.

Sequences for each species were trimmed and aligned in Mega6 (ㄷ 1993 - 2013 Koichiro Tamura, Glen Stecher, Daniel Peterson, Sudhir Kumar) by ClustalW using the default parameters. Sequences were then translated into amino acid sequences to confirm that they were free of stop codons, with the reading frame being adjusted where necessary. DNA sequence alignments were then exported in FASTA format for subsequent upload to BOLD, together with associated metadata (table 1). These data, including voucher information, taxonomic classification, photographs, DNA barcode sequences, primer information and trace files will be accessible through the public data set. New barcode data will also be deposited in GenBank.

As part of quality control, after sequencing, DNA barcodes were compared to conspecific records, where available, using BLAST $^{\odot}$ (Altschul et al. 1990) (http://blast.ncbi.nlm.nih.gov/Blast.cgi).

\section{Publicly available sequences}

Additional sequences were downloaded from BOLD. A search was done using all hoverfly species on the British Isles list (see Appendix 1) plus 'Eristalis interrupta' a synonym of E. nemorum, and Pipiza bimaculata and P. fenestrata, two species recognised by Stubbs \& Falk (2002). The FASTA files for all public sequences were then added to the FASTA files for British species generated as described above. These were 
then analysed in Mega6. The combined dataset was aligned as described above, and then trimmed to produce a series of concurrent sequences of 550bp. Kimura 2 parameter (K2P) distances were calculated (see Appendix 2), and a nearest neighbour-joining tree constructed using 1000 bootstraps (see Appendix 3, including bootstrap values). British samples identified as Microdon mutabilis agg. were excluded from the species total, but included in the comparison of pairwise distances. Microdon mutabilis agg. includes both M. mutabilis sensu stricto, and M. myrmicae. These species cannot be separated morphologically as adults. A threshold of $3 \%$ was taken as indicating either high intraspecific variation or low interspecific variation, since this was the distance below which $99 \%$ of all intraspecific pairwise comparisons were found. It is also the level used elsewhere in the study of hoverflies (Jordaens et al. 2015) and slightly higher than the lowest interspecific pairwise K2P value (2.68\%) found in Merodon hoverflies (Stahls et al. 2009).

\section{Hoverfly Record Data}

Record data was supplied by the Hoverfly Recording Scheme (HRS). The HRS is the recording scheme for hoverflies in Britain, drawing records from Local Environmental Records Centres (LERCs) throughout Britain, as well as records submitted directly to the scheme. The data consisted of the number of records for each species submitted to the scheme, to 4 September 2017.

\section{Results}

Details of all sequences used for this work is given in Appendix 4, and details of countries of origin in Appendix 5. In summary, for the specimens obtained for this study, 256 individuals of 82 species in 40 genera yielded barcode sequences of at least 550bp, for which 70 species had more than one sequence. When combined with the publicly available sequences, the dataset consisted of 2858 sequences. Following alignment, the final data set consisted of 2853 barcode sequences of 210 species, representing $74 \%$ of the British fauna. Five sequences were rejected from further analysis because they were too short, or represented parts of the genome other than the COI region. On average, 13.6 sequences per species were analysed, with the largest number of samples for a single species being 197 for Episyrphus balteatus. Sequences from 30 countries were available 
for analysis (figure 1, Appendix 5). The greatest number originated from Canada (1324, $46 \%$ of total), Germany $(436,15 \%$ of total) Norway $(422,15 \%$ of total) and the United Kingdom (260, $9 \%$ of total).

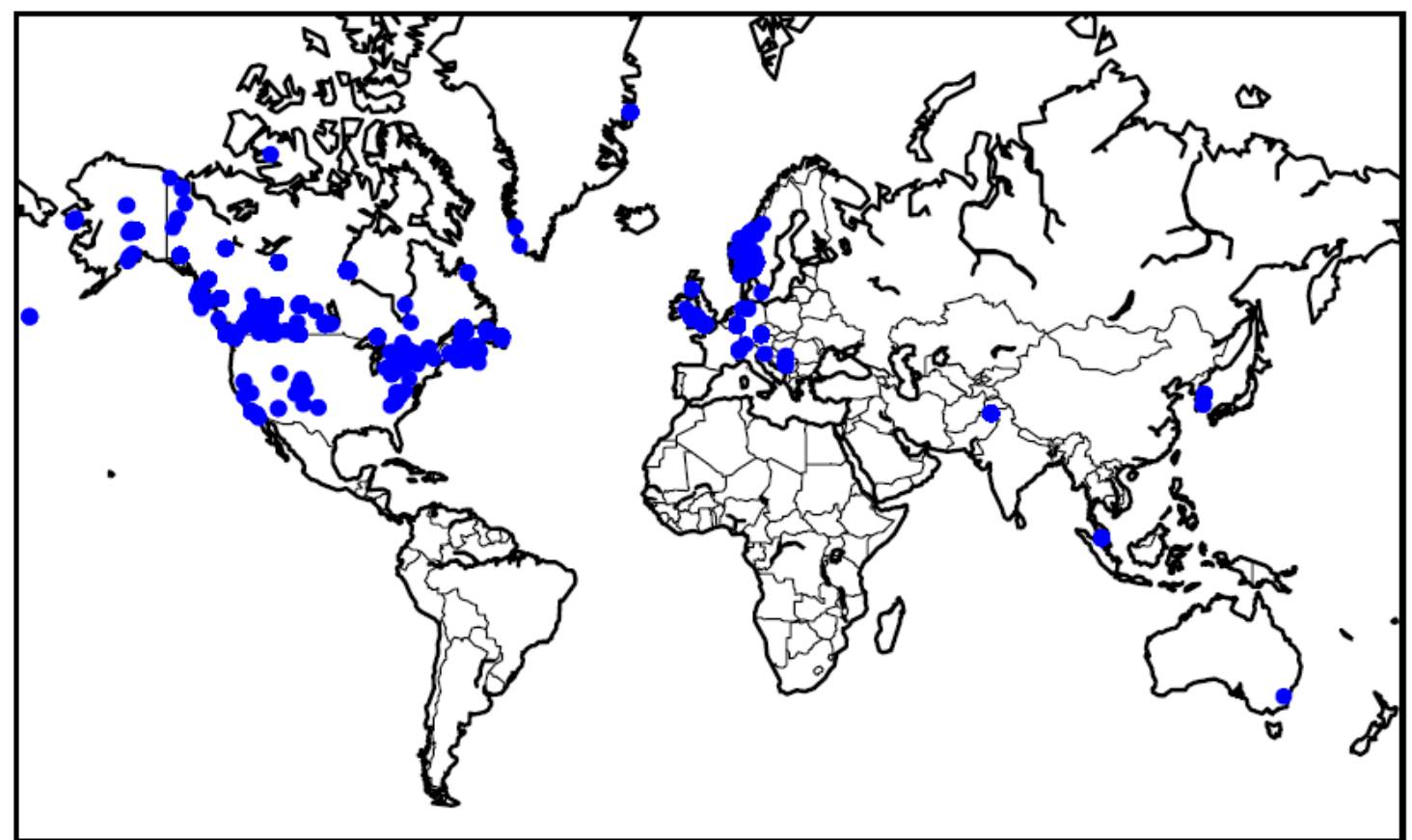

Figure 11 Distribution map of specimens of Syrphidae sampled in this study

Table 2 shows the number of sequences obtained for each species. The number of individuals of British origin barcoded as part of the study is also shown. In 9 species the barcodes from this study are the first to be published for the species. 118 species $(57.5 \%)$ had four or more barcodes whilst 35 species (16.6\%) had a single sequence. Table 2 also indicates whether a species was in the top 86 hoverfly species recorded in the Hoverfly Recording Scheme (HRS) database, together with its rank (1 = most recorded species, 86 $=86^{\text {th }}$ most recorded species). As of 4 September 2017, the HRS held 891, 286 records. These 86 species collectively represent $90 \%$ of all records in the database, and are thus those most frequently encountered by hoverfly recorders in Britain. Of these 86 species, 84 have at least one barcode. The two species lacking barcodes (with their rank), are Criorhina berberina $\left(70^{\text {th }}\right)$ and Riponnensia splendens $\left(79^{\text {th }}\right)$. The number of species 
records for all species in the HRS for which barcodes were generated by this study is 842,518 , which represents $94 \%$ of all records. 
Table 2. Taxonomic coverage of DNA barcodes obtained by sequencing for this study or publicly available. 'Total Specimens' is the total number of sequences used in this study, 'Total GB' in the total sequences obtained from sequencing insects captured in Britain, 'Total Non GB' represents the number of sequences used from non- GB sources, and 'Top $90 \%$ species records (rank)' are the top 86 species as recorded by the Hoverfly Recording Scheme to $4 / 9 / 2017$ (' 1 ' $=$ most recorded, ' $86^{\prime}=86^{\text {th }}$ most recorded species).

\begin{tabular}{|c|c|c|c|c|c|c|}
\hline Sub Family & Genus & Species & $\begin{array}{c}\text { Total } \\
\text { Specimens }\end{array}$ & Total GB & $\begin{array}{c}\text { Total Non } \\
\text { GB }\end{array}$ & $\begin{array}{c}\text { Top } 90 \% \\
\text { species records } \\
\text { (rank) }\end{array}$ \\
\hline \multirow{30}{*}{ Eristalineae } & \multirow{2}{*}{ Anasimyia } & Anasimyia contracta & 1 & 1 & 0 & \\
\hline & & Anasimyia lineata & 2 & 0 & 2 & 80 \\
\hline & Blera & Blera fallax & 1 & 0 & 1 & \\
\hline & \multirow{2}{*}{ Brachyopa } & Brachyopa pilosa & 2 & 0 & 2 & \\
\hline & & Brachyopa scutellaris & 2 & 2 & 0 & \\
\hline & Brachypalpoides & Brachypalpoides lentus & 4 & 1 & 3 & \\
\hline & Brachypalpus & Brachypalpus laphriformis & 3 & 0 & 3 & \\
\hline & Chalcosyrphus & Chalcosyrphus nemorum & 63 & 3 & 60 & 76 \\
\hline & \multirow{22}{*}{ Cheilosia } & Cheilosia albipila & 2 & 0 & 2 & \\
\hline & & Cheilosia albitarsis & 6 & 4 & 2 & 30 \\
\hline & & Cheilosia antiqua & 1 & & 1 & \\
\hline & & Cheilosia bergenstammi & 3 & 3 & 0 & 59 \\
\hline & & Cheilosia caerulescens & 1 & 0 & 1 & \\
\hline & & Cheilosia carbonaria & 2 & 0 & 2 & \\
\hline & & Cheilosia chrysocoma & 1 & 0 & 1 & \\
\hline & & Cheilosia fraterna & 5 & 4 & 1 & 81 \\
\hline & & Cheilosia grossa & 4 & 0 & 4 & \\
\hline & & Cheilosia illustrata & 6 & 4 & 2 & 25 \\
\hline & & Cheilosia impressa & 4 & 3 & 1 & 69 \\
\hline & & Cheilosia latifrons & 1 & 0 & 1 & \\
\hline & & Cheilosia longula & 2 & 0 & 2 & \\
\hline & & Cheilosia mutabilis & 5 & 0 & 5 & \\
\hline & & Cheilosia nebulosi & 1 & 0 & 1 & \\
\hline & & Cheilosia pagana & 8 & 4 & 4 & 24 \\
\hline & & Cheilosia proxima & 10 & 4 & 6 & 65 \\
\hline & & Cheilosia psilophthalma & 1 & 0 & 1 & \\
\hline & & Cheilosia pubera & 1 & 0 & 1 & \\
\hline & & Cheilosia scutellata & 7 & 3 & 4 & \\
\hline & & Cheilosia semifasciata & 1 & 0 & 1 & \\
\hline & & Cheilosia soror & 5 & 0 & 5 & \\
\hline
\end{tabular}




\begin{tabular}{|c|c|c|c|c|c|c|}
\hline Sub Family & Genus & Species & $\begin{array}{c}\text { Total } \\
\text { Specimens }\end{array}$ & Total GB & $\begin{array}{c}\text { Total Non } \\
\text { GB }\end{array}$ & $\begin{array}{c}\text { Top } 90 \% \\
\text { species records } \\
\text { (rank) } \\
\end{array}$ \\
\hline & & Cheilosia urbana & 2 & 0 & 2 & \\
\hline & & Cheilosia uviformis & 1 & 0 & 1 & \\
\hline & & Cheilosia variabilis & 5 & 4 & 1 & 51 \\
\hline & & Cheilosia velutina & 3 & 0 & 3 & \\
\hline & & Cheilosia vernalis & 5 & 2 & 3 & 60 \\
\hline & & Cheilosia vicina & 3 & 0 & 3 & \\
\hline & Chrysogaster & Chrysogaster solstitialis & 5 & 3 & 2 & 40 \\
\hline & \multirow{2}{*}{ Criorhina } & Criorhina asilica & 3 & 0 & 3 & \\
\hline & & Criorhina ranunculi & 5 & 4 & 1 & \\
\hline & \multirow{2}{*}{ Eristalinus } & Eristalinus aeneus & 5 & 4 & 1 & \\
\hline & & Eristalinus sepulchralis & 6 & 2 & 4 & 48 \\
\hline & \multirow{10}{*}{ Eristalis } & Eristalis abusiva & 2 & 0 & 2 & \\
\hline & & Eristalis arbustorum & 10 & 4 & 6 & 10 \\
\hline & & Eristalis cryptarum & 12 & 0 & 12 & \\
\hline & & Eristalis horticola & 4 & 4 & 0 & 34 \\
\hline & & Eristalis intricaria & 6 & 4 & 2 & 22 \\
\hline & & Eristalis nemorum & 7 & 3 & 4 & 18 \\
\hline & & Eristalis pertinax & 19 & 4 & 15 & 2 \\
\hline & & Eristalis rupium & 4 & 0 & 4 & \\
\hline & & Eristalis similis & 3 & 0 & 3 & \\
\hline & & Eristalis tenax & 44 & 4 & 40 & 4 \\
\hline & \multirow{3}{*}{ Eumerus } & Eumerus funeralis & 34 & 3 & 31 & 78 \\
\hline & & Eumerus ornatus & 1 & 0 & 1 & \\
\hline & & Eumerus strigatus & 10 & 0 & 10 & \\
\hline & \multirow{2}{*}{ Ferdinandea } & Ferdinandea cuprea & 9 & 2 & 7 & 53 \\
\hline & & Ferdinandea ruficornis & 3 & 0 & 3 & \\
\hline & \multirow{5}{*}{ Helophilus } & Helophilus affinis & 1 & 0 & 1 & \\
\hline & & Helophilus groenlandicus & 27 & 0 & 27 & \\
\hline & & Helophilus hybridus & 68 & 3 & 65 & 61 \\
\hline & & Helophilus pendulus & 13 & 4 & 9 & 3 \\
\hline & & Helophilus trivittatus & 17 & 3 & 14 & 63 \\
\hline & Lejogaster & Lejogaster metallina & 1 & 0 & 1 & 64 \\
\hline & \multirow{2}{*}{ Melanogaster } & Melanogaster aerosa & 1 & 0 & 1 & \\
\hline & & Melanogaster hirtella & 4 & 4 & 0 & 46 \\
\hline & Merodon & Merodon equestris & 18 & 3 & 15 & 32 \\
\hline & Myathropa & Myathropa florea & 7 & 4 & 3 & 11 \\
\hline & \multirow{4}{*}{ Neoascia } & Neoascia geniculata & 33 & 0 & 33 & \\
\hline & & Neoascia meticulosa & 2 & 0 & 2 & \\
\hline & & Neoascia obliqua & 1 & 0 & 1 & \\
\hline & & Neoascia podagrica & 8 & 3 & 5 & 28 \\
\hline
\end{tabular}




\begin{tabular}{|c|c|c|c|c|c|c|}
\hline Sub Family & Genus & Species & $\begin{array}{c}\text { Total } \\
\text { Specimens }\end{array}$ & Total GB & $\begin{array}{c}\text { Total Non } \\
\text { GB }\end{array}$ & $\begin{array}{c}\text { Top } 90 \% \\
\text { species records } \\
\text { (rank) } \\
\end{array}$ \\
\hline & & Neoascia tenur & 42 & 0 & 42 & 41 \\
\hline & \multirow{3}{*}{ Orthonevra } & Orthonevra geniculata & 2 & 0 & 2 & \\
\hline & & Orthonevra intermedia & 1 & 0 & 1 & \\
\hline & & Orthonevra nobilis & 2 & 0 & 2 & \\
\hline & \multirow{2}{*}{ Parhelophilus } & Parhelophilus consimilis & 1 & 0 & 1 & \\
\hline & & Parhelophilus versicolor & 3 & 0 & 3 & \\
\hline & \multirow{2}{*}{ Pelecocera } & Pelecocera scaevoides & 2 & 0 & 2 & \\
\hline & & Pelecocera tricincta & 1 & 0 & 1 & \\
\hline & Portevinia & Portevinia maculata & 4 & 4 & 0 & 84 \\
\hline & \multirow{2}{*}{ Rhingia } & Rhingia campestris & 21 & 4 & 17 & 9 \\
\hline & & Rhingia rostrata & 6 & 3 & 3 & \\
\hline & \multirow{3}{*}{ Sericomyia } & Sericomyia lappona & 8 & 3 & 5 & 86 \\
\hline & & Sericomyia silentis & 8 & 4 & 4 & 21 \\
\hline & & Sericomyia superbiens & 4 & 4 & 0 & \\
\hline & \multirow{2}{*}{ Sphegina } & Sphegina clunipes & 3 & 1 & 2 & 72 \\
\hline & & Sphegina sibirica & 2 & 0 & 2 & \\
\hline & Syritta & Syritta pipiens & 31 & 1 & 30 & 7 \\
\hline & Tropidia & Tropidia scita & 5 & 3 & 2 & 66 \\
\hline & \multirow{5}{*}{ Volucella } & Volucella bombylans & 7 & 4 & 3 & 26 \\
\hline & & Volucella inanis & 9 & 0 & 9 & 55 \\
\hline & & Volucella inflata & 2 & 2 & 0 & \\
\hline & & Volucella pellucens & 9 & 1 & 8 & 15 \\
\hline & & Volucella zonaria & 3 & 0 & 3 & 50 \\
\hline & & Xylota florum & 3 & 0 & 3 & \\
\hline & & Xylota jakutorum & 5 & 0 & 5 & \\
\hline & Xylota & Xylota segnis & 22 & 4 & 18 & 13 \\
\hline & & Xylota sylvarum & 4 & 0 & 4 & 52 \\
\hline & & Xylota tarda & 3 & 0 & 3 & \\
\hline \multirow{4}{*}{ Microdontineae } & \multirow{4}{*}{ Microdon } & Microdon analis & 1 & 0 & 1 & \\
\hline & & Microdon mutabilis & 2 & 0 & 2 & \\
\hline & & Microdon mutabilis agg. & 3 & 3 & 0 & \\
\hline & & Microdon myrmicae & 1 & 0 & 1 & \\
\hline \multirow{8}{*}{ Pipizineae } & \multirow{3}{*}{ Heringia } & Heringia heringi & 2 & 0 & 2 & \\
\hline & & Heringia latitarsis & 1 & 0 & 1 & \\
\hline & & Heringia pubescens & 9 & 0 & 9 & \\
\hline & \multirow{5}{*}{ Pipiza } & Pipiza austriaca & 1 & 0 & 1 & \\
\hline & & Pipiza bimaculata & 5 & 0 & 5 & \\
\hline & & Pipiza fenestrata & 4 & 0 & 4 & \\
\hline & & Pipiza lugubris & 7 & 0 & 7 & \\
\hline & & Pipiza luteitarsis & 12 & 2 & 10 & \\
\hline
\end{tabular}




\begin{tabular}{|c|c|c|c|c|c|c|}
\hline Sub Family & Genus & Species & $\begin{array}{c}\text { Total } \\
\text { Specimens }\end{array}$ & Total GB & $\begin{array}{l}\text { Total Non } \\
\text { GB }\end{array}$ & $\begin{array}{c}\text { Top } 90 \% \\
\text { species records } \\
\text { (rank) }\end{array}$ \\
\hline & & Pipiza noctiluca & 30 & 8 & 22 & 67 \\
\hline & & Pipizella viduata & 13 & 4 & 9 & 61 \\
\hline & Trichopsomyia & Trichopsomyia flavitarsis & 2 & 0 & 2 & \\
\hline & Triglyphus & Triglyphus primus & 3 & 0 & 3 & \\
\hline \multirow{36}{*}{ Syrphineae } & Baccha & Baccha elongata & 44 & 4 & 40 & 33 \\
\hline & \multirow{6}{*}{ Chrysotoxum } & Chrysotoxum arcuatum & 11 & 1 & 10 & 85 \\
\hline & & Chrysotoxum bicinctum & 11 & 4 & 7 & 35 \\
\hline & & Chrysotoxum cautum & 19 & 1 & 18 & \\
\hline & & Chrysotoxum festivum & 3 & 0 & 3 & 75 \\
\hline & & $\begin{array}{c}\text { Chrysotoxum } \\
\text { octomaculatum }\end{array}$ & 2 & 0 & 2 & \\
\hline & & Chrysotoxum vernale & 3 & 0 & 3 & \\
\hline & \multirow{7}{*}{ Dasysyrphus } & Dasysyrphus albostriatus & 8 & 3 & 5 & 47 \\
\hline & & Dasysyrphus friuliensis & 1 & 0 & 1 & \\
\hline & & Dasysyrphus hilaris & 3 & 0 & 3 & \\
\hline & & Dasysyrphus pauxillus & 19 & 0 & 19 & \\
\hline & & Dasysyrphus pinastri & 5 & 0 & 5 & \\
\hline & & Dasysyrphus tricinctus & 6 & 1 & 5 & 77 \\
\hline & & Dasysyrphus venustus & 90 & 4 & 86 & 57 \\
\hline & \multirow{3}{*}{ Didea } & Didea alneti & 2 & 0 & 2 & \\
\hline & & Didea fasciata & 1 & 0 & 1 & \\
\hline & & Didea intermedia & 2 & 0 & 2 & \\
\hline & Doros & Doros profuges & 1 & 0 & 1 & \\
\hline & \multirow{4}{*}{ Epistrophe } & Epistrophe eligans & 23 & 4 & 19 & 23 \\
\hline & & Epistrophe grossulariae & 15 & 2 & 13 & 42 \\
\hline & & Epistrophe melanostoma & 3 & 0 & 3 & \\
\hline & & Epistrophe nitidicollis & 13 & 0 & 13 & \\
\hline & Episyrphus & Episyrphus balteatus & 197 & 4 & 193 & 1 \\
\hline & Eriozona & Eriozona syrphoides & 1 & 0 & 1 & \\
\hline & \multirow{9}{*}{ Eupeodes } & Eupeodes bucculatus & 6 & 0 & 6 & \\
\hline & & Eupeodes corollae & 92 & 4 & 88 & 17 \\
\hline & & Eupeodes goeldlini & 1 & 0 & 1 & \\
\hline & & Eupeodes lapponicus & 18 & 0 & 18 & \\
\hline & & Eupeodes latifasciatus & 66 & 0 & 66 & 58 \\
\hline & & Eupeodes lundbecki & 3 & 0 & 3 & \\
\hline & & Eupeodes luniger & 12 & 4 & 8 & 16 \\
\hline & & Eupeodes nielseni & 3 & 0 & 3 & \\
\hline & & Eupeodes nitens & 3 & 0 & 3 & \\
\hline & \multirow{3}{*}{ Leucozona } & Leucozona glaucia & 7 & 4 & 3 & 45 \\
\hline & & Leucozona laternaria & 3 & 1 & 2 & 71 \\
\hline & & Leucozona lucorum & 7 & 3 & 4 & 27 \\
\hline
\end{tabular}




\begin{tabular}{|c|c|c|c|c|c|c|}
\hline Sub Family & Genus & Species & $\begin{array}{c}\text { Total } \\
\text { Specimens }\end{array}$ & Total GB & $\begin{array}{c}\text { Total Non } \\
\text { GB }\end{array}$ & $\begin{array}{c}\text { Top } 90 \% \\
\text { species records } \\
\text { (rank) } \\
\end{array}$ \\
\hline & Megasyrphus & Megasyrphus erraticus & 1 & 0 & 1 & \\
\hline & \multirow{7}{*}{ Melangyna } & Melangyna arctica & 19 & 0 & 19 & \\
\hline & & Melangyna barbifrons & 2 & 0 & 2 & \\
\hline & & Melangyna compositarum & 6 & 0 & 6 & 74 \\
\hline & & Melangyna ericarum & 1 & 0 & 1 & \\
\hline & & Melangyna labiatarum & 11 & 0 & 11 & -74 \\
\hline & & Melangyna lasiophthalma & 29 & 0 & 29 & 83 \\
\hline & & Melangyna umbellatarum & 2 & 0 & 2 & \\
\hline & \multirow{3}{*}{ Melanostoma } & Melanostoma dubium & 1 & 0 & 1 & \\
\hline & & Melanostoma mellinum & 98 & 4 & 94 & 12 \\
\hline & & Melanostoma scalare & 10 & 4 & 6 & 6 \\
\hline & \multirow{2}{*}{ Meliscaeva } & Meliscaeva auricollis & 7 & 4 & 3 & 37 \\
\hline & & Meliscaeva cinctella & 99 & 4 & 95 & 39 \\
\hline & \multirow{2}{*}{ Paragus } & Paragus haemorrhous & 118 & 0 & 118 & 73 \\
\hline & & Paragus tibialis & 6 & 0 & 6 & \\
\hline & \multirow{5}{*}{ Parasyrphus } & Parasyrphus annulatus & 6 & 0 & 6 & \\
\hline & & Parasyrphus malinellus & 12 & 0 & 12 & \\
\hline & & Parasyrphus nigritarsis & 9 & 0 & 9 & \\
\hline & & Parasyrphus punctulatus & 8 & 0 & 8 & 82 \\
\hline & & Parasyrphus vittiger & 4 & 0 & 4 & \\
\hline & \multirow{20}{*}{ Platycheirus } & Platycheirus albimanus & 44 & 2 & 42 & 5 \\
\hline & & Platycheirus ambiguus & 2 & 0 & 2 & \\
\hline & & Platycheirus amplus & 3 & 0 & 3 & \\
\hline & & Platycheirus angustatus & 9 & 0 & 9 & 56 \\
\hline & & Platycheirus aurolateralis & 1 & 0 & 1 & \\
\hline & & Platycheirus clypeatus & 63 & 1 & 62 & 20 \\
\hline & & Platycheirus discimanus & 3 & 0 & 3 & \\
\hline & & Platycheirus europaeus & 2 & 0 & 2 & \\
\hline & & Platycheirus fulviventris & 12 & 4 & 8 & \\
\hline & & Platycheirus granditarsis & 60 & 3 & 57 & 38 \\
\hline & & Platycheirus manicatus & 9 & 3 & 6 & 36 \\
\hline & & Platycheirus melanopsis & 2 & 0 & 2 & \\
\hline & & Platycheirus nielseni & 10 & 0 & 10 & \\
\hline & & Platycheirus occultus & 4 & 0 & 4 & \\
\hline & & Platycheirus peltatus & 14 & 2 & 12 & 44 \\
\hline & & Platycheirus perpallidus & 8 & 0 & 8 & \\
\hline & & Platycheirus podagratus & 36 & 0 & 36 & \\
\hline & & Platycheirus rosarum & 35 & 3 & 32 & 54 \\
\hline & & Platycheirus scambus & 123 & 0 & 123 & \\
\hline & & Platycheirus scutatus & 19 & 0 & 19 & 29 \\
\hline
\end{tabular}




\begin{tabular}{|c|c|c|c|c|c|c|}
\hline Sub Family & Genus & Species & $\begin{array}{c}\text { Total } \\
\text { Specimens }\end{array}$ & Total GB & $\begin{array}{c}\text { Total Non } \\
\text { GB }\end{array}$ & $\begin{array}{c}\text { Top } 90 \% \\
\text { species records } \\
\text { (rank) } \\
\end{array}$ \\
\hline & & Platycheirus sticticus & 1 & 0 & 1 & \\
\hline & & Platycheirus tarsalis & 4 & 1 & 3 & \\
\hline & \multirow{3}{*}{ Scaeva } & Scaeva albomaculata & 3 & 0 & 3 & \\
\hline & & Scaeva pyrastri & 33 & 4 & 29 & 31 \\
\hline & & Scaeva selenitica & 6 & 0 & 6 & \\
\hline & \multirow{8}{*}{ Sphaerophoria } & $\begin{array}{l}\text { Sphaerophoria } \\
\text { bankowskae }\end{array}$ & 2 & 0 & 2 & \\
\hline & & Sphaerophoria batava & 2 & 0 & 2 & \\
\hline & & Sphaerophoria interrupta & 2 & 0 & 2 & 68 \\
\hline & & Sphaerophoria philanthus & 35 & 0 & 35 & \\
\hline & & Sphaerophoria rueppellii & 3 & 0 & 3 & \\
\hline & & Sphaerophoria scripta & 14 & 1 & 13 & 14 \\
\hline & & Sphaerophoria taeniata & 3 & 0 & 3 & \\
\hline & & Sphaerophoria virgata & 3 & 0 & 3 & \\
\hline & \multirow{5}{*}{ Syrphus } & Syrphus nitidifrons & 1 & 0 & 1 & \\
\hline & & Syrphus rectus & 6 & 0 & 6 & \\
\hline & & Syrphus ribesii & 141 & 3 & 138 & 8 \\
\hline & & Syrphus torvus & 74 & 3 & 71 & 43 \\
\hline & & Syrphus vitripennis & 27 & 4 & 23 & 19 \\
\hline & \multirow{3}{*}{ Xanthogramma } & $\begin{array}{l}\text { Xanthogramma } \\
\text { citrofasciatum }\end{array}$ & 2 & 0 & 2 & \\
\hline & & $\begin{array}{c}\text { Xanthogramma } \\
\text { pedissequum }\end{array}$ & 2 & 0 & 2 & 49 \\
\hline & & $\begin{array}{c}\text { Xanthogramma } \\
\text { stackelbergi }\end{array}$ & 1 & 0 & 1 & \\
\hline
\end{tabular}

The frequency of intra and interspecific barcode distances between individuals are shown in figure 2. The intraspecific genetic distance between individuals varied from 0 to $13 \%$ $($ mean $=0.8 \%)$. Of the intraspecific distances, $900(1 \%$ of total $)$ distances between individuals exceeded 3\%. One species, 10 individuals of Cheilosia proxima, had a mean intraspecific distance greater than $3 \%$ (3.6\%). Species represented by a single individual were excluded from this analysis. Interspecific divergences varied from $0 \%-25 \%$ (mean $13.0 \%)$. Of these, $24,216(0.3 \%)$ of individual interspecific distances were $3 \%$ or less. Thus the mean genetic distance between species was 16.25 times higher than that within species. 
Figure 12 Frequency histogram of intraspecific and interspecific K2P distances (expressed as percentages) for all COI sequences for hoverflies recorded in Britain used as part of this study.

Table 3 shows the mean congeneric distances for each genus. Amongst the genera with the largest genetic distance between species (i.e. the genera where barcodes had the greatest discrimination between species) are two notably speciose genera: Cheilosia (mean divergence between species $=7.4 \%$ ) and Platycheirus (mean divergence between species $=6.7$ ). Genera where mean genetic distance was below 3\% were Melanogaster, Melanostoma, Paragus, Sphaerophoria and Xanthogramma. 
Table 3 Mean \% differences in K2P distance amongst British hoverfly genera represented by more than one species.

\begin{tabular}{|c|c|c|c|c|}
\hline Genus & $\begin{array}{l}\text { Mean \% } \\
\text { Distance }\end{array}$ & $\begin{array}{c}\text { Mean } \\
\text { K2P }\end{array}$ & $\begin{array}{c}\text { Stand } \\
\text { Dev }\end{array}$ & $\begin{array}{c}\text { No. } \\
\text { Species }\end{array}$ \\
\hline Anasimyia & 12.5 & 0.12 & 0.000 & 2 \\
\hline Brachyopa & 6.1 & 0.06 & 0.000 & 2 \\
\hline Cheilosia & 7.4 & 0.07 & 0.019 & 28 \\
\hline Chrysotoxum & 5.6 & 0.06 & 0.017 & 6 \\
\hline Criorhina & 10.6 & 0.11 & 0.002 & 2 \\
\hline Dasysyrphus & 5.6 & 0.06 & 0.016 & 7 \\
\hline Didea & 4.9 & 0.05 & 0.018 & 3 \\
\hline Epistrophe & 8.4 & 0.08 & 0.008 & 4 \\
\hline Eristalinus & 8.6 & 0.09 & 0.001 & 2 \\
\hline Eristalis & 7.2 & 0.07 & 0.013 & 11 \\
\hline Eumerus & 4.3 & 0.04 & 0.022 & 3 \\
\hline Eupeodes & 4.4 & 0.04 & 0.023 & 9 \\
\hline Ferdinandea & 8.1 & 0.08 & 0.001 & 2 \\
\hline Helophilus & 5.7 & 0.06 & 0.009 & 5 \\
\hline Heringia & 4.5 & 0.05 & 0.019 & 3 \\
\hline Leucozona & 5.8 & 0.06 & 0.008 & 3 \\
\hline Melangyna & 4.4 & 0.04 & 0.010 & 7 \\
\hline Melanogaster & 0.9 & 0.01 & 0.000 & 2 \\
\hline Melanostoma & 1.1 & 0.01 & 0.013 & 3 \\
\hline Meliscaeva & 7.4 & 0.07 & 0.001 & 2 \\
\hline Microdon & 6.1 & 0.06 & 0.080 & 4 \\
\hline Neoascia & 3.9 & 0.04 & 0.010 & 5 \\
\hline Orthonevra & 6.3 & 0.06 & 0.002 & 3 \\
\hline Paragus & 2.6 & 0.03 & 0.004 & 2 \\
\hline Parasyrphus & 5.0 & 0.05 & 0.011 & 5 \\
\hline Parhelophilus & 5.7 & 0.06 & 0.002 & 2 \\
\hline Pelecocera & 6.7 & 0.07 & 0.001 & 2 \\
\hline Pipiza & 3.9 & 0.04 & 0.021 & 6 \\
\hline Platycheirus & 6.7 & 0.07 & 0.020 & 22 \\
\hline Rhingia & 6.2 & 0.06 & 0.001 & 2 \\
\hline Scaeva & 3.4 & 0.03 & 0.010 & 3 \\
\hline Sericomyia & 3.7 & 0.04 & 0.021 & 3 \\
\hline Sphaerophoria & 0.7 & 0.01 & 0.005 & 8 \\
\hline Sphegina & 9.6 & 0.10 & 0.001 & 2 \\
\hline Syrphus & 4.7 & 0.05 & 0.011 & 5 \\
\hline Volucella & 7.3 & 0.07 & 0.019 & 5 \\
\hline Xanthogramma & 0.8 & 0.01 & 0.005 & 3 \\
\hline Xylota & 6.8 & 0.07 & 0.009 & 5 \\
\hline
\end{tabular}


Pairs of species that show low divergence in their mean K2P distance, where the distance was $3 \%$ or less (deWaard, Hebert \& Humble 2011), are shown in table 4. In a dataset of 210 species, there are 21,945 potential species pairs $(n(n-1) / 2)$. Of these, 110 species pairs $(0.5 \%)$ had a mean K2P divergence of $3 \%$ or less. All the species pairs with low divergence came from species in the same genus.

Table 4 Pairs of species of British hoverflies with a mean K2P distance of $3 \%$ or less. The number of specimens on which distance has been calculated, and the comparisons using 10 or fewer specimens are shown.

\begin{tabular}{|c|c|c|c|c|c|}
\hline Species A & Species B & $\begin{array}{l}\text { Mean K2P } \\
\text { distance \% }\end{array}$ & $\begin{array}{l}\text { No. First } \\
\text { species }\end{array}$ & $\begin{array}{l}\text { No. Second } \\
\text { Species }\end{array}$ & $\begin{array}{c}\text { No. pair }<10 \\
(1=\text { yes, } 0= \\
\text { No })\end{array}$ \\
\hline Cheilosia albipila & Cheilosia grossa & 2.2 & 2 & 4 & 1 \\
\hline Cheilosia caerulescens & Cheilosia antiqua & 0.2 & 1 & 1 & 1 \\
\hline Cheilosia longula & Cheilosia soror & 2.9 & 2 & 5 & 1 \\
\hline Cheilosia psilophthalma & Cheilosia urbana & 0.1 & 1 & 2 & 1 \\
\hline Cheilosia uviformis & Cheilosia urbana & 0.1 & 1 & 2 & 1 \\
\hline Cheilosia vernalis & Cheilosia fraternaa & 1.2 & 5 & 5 & 1 \\
\hline Chrysotoxum bicinctum & Chrysotoxum vernale & 1.8 & 11 & 3 & 0 \\
\hline Chrysotoxum bicinctum & Chrysotoxum festivum & 2.0 & 11 & 3 & 0 \\
\hline Chrysotoxum octomaculatum & Chrysotoxum bicinctum & 2.1 & 2 & 11 & 0 \\
\hline Chrysotoxum octomaculatum & Chrysotoxum vernale & 2.8 & 2 & 3 & 1 \\
\hline Chrysotoxum octomaculatum & Chrysotoxum festivum & 1.2 & 2 & 3 & 1 \\
\hline Chrysotoxum vernale & Chrysotoxum festivum & 2.1 & 3 & 3 & 1 \\
\hline Dasysyrphus pinastri & Dasysyrphus pauxillus & 2.1 & 5 & 19 & 0 \\
\hline Dasysyrphus venustus & Dasysyrphus hilaris & 0.9 & 90 & 3 & 0 \\
\hline Eristalis arbustorum & Eristalis abusiva & 2.1 & 10 & 2 & 0 \\
\hline Eupeodes bucculatus & Eupeodes lundbecki & 1.0 & 6 & 3 & 1 \\
\hline Eupeodes bucculatus & Eupeodes corollae & 1.7 & 6 & 92 & 0 \\
\hline Eupeodes goeldlini & Eupeodes luniger & 0.3 & 1 & 12 & 0 \\
\hline Eupeodes goeldlini & Eupeodes nielseni & 0.7 & 1 & 3 & 1 \\
\hline Eupeodes goeldlini & Eupeodes nitens & 0.3 & 1 & 3 & 1 \\
\hline Eupeodes goeldlini & Eupeodes latifasciatus & 2.4 & 1 & 66 & 0 \\
\hline Eupeodes goeldlini & Eupeodes bucculatus & 0.7 & 1 & 6 & 1 \\
\hline Eupeodes goeldlini & Eupeodes lundbecki & 0.2 & 1 & 3 & 1 \\
\hline Eupeodes goeldlini & Eupeodes corollae & 2.3 & 1 & 92 & 0 \\
\hline Eupeodes latifasciatus & Eupeodes bucculatus & 2.9 & 66 & 6 & 0 \\
\hline Eupeodes latifasciatus & Eupeodes lundbecki & 2.2 & 66 & 3 & 0 \\
\hline Eupeodes lundbecki & Eupeodes corollae & 2.5 & 3 & 92 & 0 \\
\hline Eupeodes luniger & Eupeodes nielseni & 0.7 & 12 & 3 & 0 \\
\hline Eupeodes luniger & Eupeodes nitens & 0.2 & 12 & 3 & 0 \\
\hline
\end{tabular}




\begin{tabular}{|c|c|c|c|c|c|}
\hline Species A & Species B & $\begin{array}{l}\text { Mean K2P } \\
\text { distance \% }\end{array}$ & $\begin{array}{l}\text { No. First } \\
\text { species }\end{array}$ & $\begin{array}{l}\text { No. Second } \\
\text { Species }\end{array}$ & $\begin{array}{c}\text { No. pair }<10 \\
(1=\text { yes, } 0= \\
\text { No })\end{array}$ \\
\hline Eupeodes luniger & Eupeodes latifasciatus & 2.3 & 12 & 66 & 0 \\
\hline Eupeodes luniger & Eupeodes bucculatus & 1.1 & 12 & 6 & 0 \\
\hline Eupeodes luniger & Eupeodes lundbecki & 0.3 & 12 & 3 & 0 \\
\hline Eupeodes luniger & Eupeodes corollae & 2.4 & 12 & 92 & 0 \\
\hline Eupeodes nielseni & Eupeodes nitens & 0.6 & 3 & 3 & 1 \\
\hline Eupeodes nielseni & Eupeodes latifasciatus & 2.7 & 3 & 66 & 0 \\
\hline Eupeodes nielseni & Eupeodes bucculatus & 1.4 & 3 & 6 & 1 \\
\hline Eupeodes nielseni & Eupeodes lundbecki & 0.5 & 3 & 3 & 1 \\
\hline Eupeodes nielseni & Eupeodes corollae & 3.0 & 3 & 92 & 0 \\
\hline Eupeodes nitens & Eupeodes latifasciatus & 2.3 & 3 & 66 & 0 \\
\hline Eupeodes nitens & Eupeodes bucculatus & 1.0 & 3 & 6 & 1 \\
\hline Eupeodes nitens & Eupeodes lundbecki & 0.2 & 3 & 3 & 1 \\
\hline Eupeodes nitens & Eupeodes corollae & 2.5 & 3 & 92 & 0 \\
\hline Helophilus affinis & Helophilus groenlandicus & 2.6 & 1 & 27 & 0 \\
\hline Heringia pubescens & Heringia latitarsis & 1.7 & 9 & 1 & 1 \\
\hline Melangyna ericarum & Melangyna umbellatarum & 1.8 & 1 & 2 & 1 \\
\hline Melangyna lasiophthalma & Melangyna compositarum & 2.7 & 29 & 6 & 0 \\
\hline Melanogaster hirtella & Melanogaster aerosa & 0.9 & 4 & 1 & 1 \\
\hline Melanostoma mellinum & Melanostoma scalare & 1.1 & 98 & 10 & 0 \\
\hline Melanostoma mellinum & Melanostoma dubium & 1.1 & 98 & 1 & 0 \\
\hline Melanostoma scalare & Melanostoma dubium & 0.1 & 10 & 1 & 0 \\
\hline Microdon mutabilis-agg. & Microdon mutabilis & 0.2 & 3 & 2 & 1 \\
\hline Microdon myrmicae & Microdon mutabilis-agg. & 0.4 & 1 & 3 & 1 \\
\hline Microdon myrmicae & Microdon mutabilis & 0.2 & 1 & 2 & 1 \\
\hline Neoascia podagrica & Neoascia geniculate & 2.8 & 8 & 33 & 0 \\
\hline Paragus haemorrhous & Paragus tibialis & 2.6 & 118 & 6 & 0 \\
\hline Pipiza austriaca & Pipiza fenestrate & 1.1 & 1 & 4 & 1 \\
\hline Pipiza bimaculata & Pipiza noctiluca & 0.8 & 5 & 30 & 0 \\
\hline Pipiza bimaculata & Pipiza austriaca & 1.7 & 5 & 1 & 1 \\
\hline Pipiza bimaculata & Pipiza fenestrata & 1.0 & 5 & 4 & 1 \\
\hline Pipiza noctiluca & Pipiza austriaca & 1.2 & 30 & 1 & 0 \\
\hline Pipiza noctiluca & Pipiza fenestrata & 0.5 & 30 & 4 & 0 \\
\hline Platycheirus amplus & Platycheirus peltatus & 0.8 & 3 & 14 & 0 \\
\hline Platycheirus angustatus & Platycheirus occultus & 2.1 & 9 & 4 & 0 \\
\hline Platycheirus angustatus & Platycheirus fulviventris & 2.4 & 9 & 12 & 0 \\
\hline Platycheirus angustatus & Platycheirus europaeus & 1.2 & 9 & 2 & 0 \\
\hline Platycheirus angustatus & Platycheirus clypeatus & 2.4 & 9 & 63 & 0 \\
\hline Platycheirus aurolateralis & Platycheirus scutatus & 0.4 & 1 & 19 & 0 \\
\hline Platycheirus europaeus & Platycheirus clypeatus & 2.4 & 2 & 63 & 0 \\
\hline Platycheirus fulviventris & Platycheirus europaeus & 2.4 & 12 & 2 & 0 \\
\hline Platycheirus fulviventris & Platycheirus clypeatus & 0.9 & 12 & 63 & 0 \\
\hline Platycheirus nielseni & Platycheirus amplus & 0.6 & 10 & 3 & 0 \\
\hline Platycheirus nielseni & Platycheirus peltatus & 0.5 & 10 & 14 & 0 \\
\hline
\end{tabular}




\begin{tabular}{|c|c|c|c|c|c|}
\hline Species A & Species B & $\begin{array}{l}\text { Mean K2P } \\
\text { distance \% }\end{array}$ & $\begin{array}{l}\text { No. First } \\
\text { species }\end{array}$ & $\begin{array}{l}\text { No. Second } \\
\text { Species }\end{array}$ & $\begin{array}{c}\text { No. pair }<10 \\
(1=\text { yes, } 0= \\
\text { No })\end{array}$ \\
\hline Platycheirus occultus & Platycheirus fulviventris & 2.0 & 4 & 12 & 0 \\
\hline Platycheirus occultus & Platycheirus europaeus & 2.0 & 4 & 2 & 1 \\
\hline Platycheirus occultus & Platycheirus clypeatus & 1.9 & 4 & 63 & 0 \\
\hline Platycheirus tarsalis & Platycheirus manicatus & 2.0 & 4 & 9 & 0 \\
\hline Scaeva albomaculata & Scaeva pyrastri & 2.1 & 3 & 33 & 0 \\
\hline Sericomyia lappona & Sericomyia silentis & 1.6 & 8 & 8 & 0 \\
\hline Sphaerophoria batava & Sphaerophoria virgata & 0.5 & 2 & 3 & 1 \\
\hline Sphaerophoria batava & Sphaerophoria bankowskae & 0.8 & 2 & 2 & 1 \\
\hline Sphaerophoria interrupta & Sphaerophoria rueppellii & 1.9 & 2 & 3 & 1 \\
\hline Sphaerophoria interrupta & Sphaerophoria batava & 0.7 & 2 & 2 & 1 \\
\hline Sphaerophoria interrupta & Sphaerophoria virgata & 0.9 & 2 & 3 & 1 \\
\hline Sphaerophoria interrupta & Sphaerophoria bankowskae & 1.0 & 2 & 2 & 1 \\
\hline Sphaerophoria philanthus & Sphaerophoria taeniata & 1.0 & 35 & 3 & 0 \\
\hline Sphaerophoria philanthus & Sphaerophoria interrupta & 0.9 & 35 & 2 & 0 \\
\hline Sphaerophoria philanthus & Sphaerophoria rueppellii & 1.5 & 35 & 3 & 0 \\
\hline Sphaerophoria philanthus & Sphaerophoria batava & 0.9 & 35 & 2 & 0 \\
\hline Sphaerophoria philanthus & Sphaerophoria virgata & 0.7 & 35 & 3 & 0 \\
\hline Sphaerophoria philanthus & Sphaerophoria bankowskae & 0.3 & 35 & 2 & 0 \\
\hline Sphaerophoria rueppellii & Sphaerophoria batava & 1.8 & 3 & 2 & 1 \\
\hline Sphaerophoria rueppellii & Sphaerophoria virgata & 1.7 & 3 & 3 & 1 \\
\hline Sphaerophoria rueppellii & Sphaerophoria bankowskae & 1.3 & 3 & 2 & 1 \\
\hline Sphaerophoria scripta & Sphaerophoria philanthus & 0.3 & 14 & 35 & 0 \\
\hline Sphaerophoria scripta & Sphaerophoria taeniata & 1.0 & 14 & 3 & 0 \\
\hline Sphaerophoria scripta & Sphaerophoria interrupta & 0.9 & 14 & 2 & 0 \\
\hline Sphaerophoria scripta & Sphaerophoria rueppellii & 1.5 & 14 & 3 & 0 \\
\hline Sphaerophoria scripta & Sphaerophoria batava & 0.9 & 14 & 2 & 0 \\
\hline Sphaerophoria scripta & Sphaerophoria virgata & 0.7 & 14 & 3 & 0 \\
\hline Sphaerophoria scripta & Sphaerophoria bankowskae & 0.5 & 14 & 2 & 0 \\
\hline Sphaerophoria taeniata & Sphaerophoria interrupta & 0.2 & 3 & 2 & 1 \\
\hline Sphaerophoria taeniata & Sphaerophoria rueppellii & 1.9 & 3 & 3 & 1 \\
\hline Sphaerophoria taeniata & Sphaerophoria batava & 0.6 & 3 & 2 & 1 \\
\hline Sphaerophoria taeniata & Sphaerophoria virgata & 0.9 & 3 & 3 & 1 \\
\hline Sphaerophoria taeniata & Sphaerophoria bankowskae & 1.1 & 3 & 2 & 1 \\
\hline Sphaerophoria virgata & Sphaerophoria bankowskae & 0.6 & 3 & 2 & 1 \\
\hline Syrphus rectus & Syrphus vitripennis & 1.5 & 6 & 27 & 0 \\
\hline Volucella zonaria & Volucella pellucens & 2.4 & 3 & 9 & 0 \\
\hline Xanthogramma pedissequum & Xanthogramma citrofasciatum & 1.1 & 2 & 2 & 1 \\
\hline Xanthogramma stackelbergi & Xanthogramma citrofasciatum & 1.1 & 1 & 2 & 1 \\
\hline
\end{tabular}

Of the species pairs, $46(42 \%)$ had ten or fewer individuals in the paired comparison. The genera with the most species pairs showing low divergence were Eupeodes (27 pairs), 
Platycheirus (15 pairs), and Sphaerophoria (28 pairs). However, when the number of species in each genus is considered (and therefore the possible number of pairs of species), Eupeodes (9 species, 36 potential pairs, 27 low divergence pairs $=75 \%$ ) and Sphaerophoria ( 8 species, 28 potential pairs, 28 low divergence pairs $=100 \%$ ) are the two genera with the most species showing low divergence. Although Platycheirus also has a number of pairs with low mean divergence, this is a low proportion of the genus (22 species, 231 potential pairs, 15 low divergence pairs $=6.5 \%$ ), consistent with the high overall divergence between species for this genus shown in table 3. Other genera with pairs of species showing poor discrimination include Pipiza, Melanostoma, and Xanthogramma.

British species with no publicly available barcode sequence are listed in Appendix 6.

\section{Discussion}

Our results indicate that the COI barcode is a reliable tool for differentiating between hoverfly species in the British Isles. There is a clear barcode gap between the range of intraspecific $\mathrm{K} 2 \mathrm{P}$ distances and interspecific distances (figure 2). However, despite the impoverished hoverfly fauna in the British Isles compared to mainland Europe, there were still a small number of instances where COI may be insufficient for identification to species level. For many species, the low numbers of publicly available sequences means that further work is required to fully assess the value of $\mathrm{COI}$ in species discrimination.

Most genera had relatively high levels of divergence between their species (table 2). This was the case for two of the most taxonomically challenging genera, Cheilosia and Platycheirus (Ball \& Morris 2013). Cheilosia is the most speciose hoverfly genus in Europe (Stahls \& Nyblom 2000; Stahls \& Barkalov 2017) and also in Britain, whilst Platycheirus is the second most speciose genus in Britain (26 species, compared to 37 in Cheilosia) (Chandler 2017). Both genera showed relatively high mean differences between species $(7.1 \%$ and $5.9 \%$ respectively). Other taxonomically difficult taxa, because of their small size, such as the genus Pelecocera (4.6\%) Sphegina (5.8\%) and Brachyopa (4.0\%) were also differentiated by DNA barcoding.

In contrast, a small number of widespread genera showed low divergence in their K2P distance. These include genera where morphological identification can be challenging, 
such as Pipiza and Neoascia, as well as genera which can be readily identified without the need for microscopy such as Sericomyia, Rhingia, Melanostoma and Meliscaeva. COI barcodes have been used successfully in North America to differentiate Sericomyia species (Skevington \& Thompson 2012), where S. lappona was shown to be most closely related to $S$. militaris, a New World species (S. silentis does not occur in North America). The genus Melanostoma in particular is known to have species that share identical COI haplotypes, but has had its taxonomy in Europe resolved using a combination of COI and the nuclear second internal transcribed spacer ITS2 (Haarto \& Stahls 2014).

When comparing those species with low divergences in their $\mathrm{K} 2 \mathrm{P}$ distance, it is notable that only 110 species pairs out of 21,945 potential species pairs $(0.5 \%)$ had a mean divergence of $3 \%$ or less. This demonstrates that, despite the genera where discrimination is low (see below), COI sequences are effective in identifying most hoverfly species. However, there are two genera where discrimination was particularly poor. Firstly, in Eupeodes, with nine species in Britain, 27 out of 36 potential species pairs showed low mean K2P divergence. In Britain there are three Eupeodes species that are common and widespread -E. luniger, E. corollae and E. latifasciatus, with the six remaining species either localised geographically or occurring as vagrants. Low mean distances occurred between E. luniger and both E. corollae and E. latifasciatus, as well as the rarer species. E. corollae has been demonstrated to be monophyletic by investigating its entire mitochondrial genome ( $\mathrm{Pu}$ et al. 2017), but the taxonomy of this genus remains in flux (Ball \& Morris 2013) with three unnamed possible British species (Eupeodes species A, B and C, sensu Stubbs and Falk (2002)). Our results suggest that the COI barcode region may be insufficient to reliably identify British species in this genus.

Secondly, in the genus Sphaerophoria, all 28 potential pairs showed low K2P divergence. Apart from Sphaerophoria scripta, which can be recognised by its long abdomen, identification in this genus is particularly difficult. Males can only be identified by dissection of the genitalia (Stubbs \& Falk 2002), whilst the females cannot be identified to species morphologically. This raises the possibility that the individuals from which publicly available sequences were derived were misidentified. Sphaerophoria scripta is also known to be a genetically diverse species (Raymond, Plantegenest \& Vialatte 2013), and an investigation of six Sphaerophoria species using a combination of COI, 28s and 12s genes found them to be paraphyletic with the African genus Exallandra (Mengual, 
Stahls \& Rojo 2008). These results, together with this study, indicate that the COI gene alone is insufficient to identify Sphaerophoria specimens to species.

From a monitoring perspective, the high level of interspecific COI divergence amongst most hoverflies in this study indicates that they can be used to identify most specimens to species level. This technique has already been applied to monitoring programmes collecting mixed samples of Diptera and other taxa (Geiger et al. 2016; Moriniere et al. 2016), and has been used to investigate the ecology of previously unidentifiable hoverfly larval stages (Andric et al. 2014). That 84 of the 86 species most commonly recorded hoverfly species in Britain have COI barcodes in this study suggests that this tool is viable for use in next generation sequencing of mixed species samples from Britain, that might be derived from a monitoring using malaise or pan traps, in most situations (Ji et al. 2013). However, there are limitations to the COI barcode library presented here. Many species are represented by a relatively small number of individuals, and require further sequence sampling to confirm the validity of species separation using COI barcodes. Moreover, 74 British species have no publicly available COI sequences. Further work is required to integrate these species into this framework, and identify any additional taxa where discrimination between species is limited. It should also be emphasised that the COI library presented here is purely an identification tool; a small divergence in the COI gene between two hoverfly species does not imply they are taxonomically closely related. Such a determination would rely on multiple gene loci, together with morphological characters (Stahls et al. 2003; Mengual, Stahls \& Rojo 2008).

In conclusion, this study has produced two outputs. The first is a reference library for most British hoverfly species, and the majority of the most frequently recorded species, that provides species-level identification and is available for use in biodiversity monitoring of this important pollinator guild. For the small proportion of taxa that cannot be identified to species, resolution to a pair of species or genus is possible. The second output is that, by identifying species-groups that have few or no sequences available, it indicates where effort is required to build a truly comprehensive library of British hoverfly species.

\section{Acknowledgments}


The authors would like to thank Paul Leland, Stephen Plummer, Neil Price and Diana Westmoreland for providing specimens for this study. Mark Pavett at NMW reviewed the morphological identifications. Stuart Ball and Roger Morris provided the data from the Hoverfly Recording Scheme.

\section{References}

Altschul, S.F., Gish, W., Miller, W., Myers, E.W. \& Lipman, D.J. (1990) Basic local alignment search tool. Journal of Molecular Biology, , 215, 403 - 410

Ambrosino, M.D., Luna, J.M., Jepson, P.C. \& Wratten, S.D. (2006) Relative Frequencies of Visits to Selected Insectary Plants by Predatory Hoverflies (Diptera: Syrphidae), Other Beneficial Insects, and Herbivores. Environmental Entomology, 35, $394-400$.

Andric, A., Sikoparija, B., Obreht, D., Dan, M., Preradovic, J., Radenkovic, S., PerezBanon, C. \& Vujic, A. (2014) DNA barcoding applied: identifying the larva of Merodon avidus (Diptera: Syrphidae). Acta Entomologica Musei Nationalis Pragae, 54, 741-757.

Ball, S. \& Morris, R. (2013) Britain's Hoverflies; An introduction to the hoverflies of Britain. Princeton University Press.

Ball, S., Morris, R., Rotheray, G. \& Watt, K. (2011) Atlas of the Hoverflies af Great Britain (Diptera, Syrphidae). Wallingford Biological Records Centre

Blitzer, E.J., Gibbs, J., Park, M.G. \& Danforth, B.N. (2016) Pollination services for apple are dependent on diverse wild bee communities. Agriculture, Ecosystems \& Environment, 221, 1-7.

Carvell, C., Isaac, N.J.B., Jitlal, M., Peyton, J., Powney, G.D., Roy, D.B., Vanbergen, A.J., O’Connor, R.S., Jones, C.M., Kunin, W.E., Breeze, T.D., Garratt, M.P.D., Potts, S.G., Harvey, M., Ansine, J., Comont, R.F., Lee, P., Edwards, M., Roberts, S.P.M., Morris, R.K.A., Musgrove, A.J., Brereton, T., Hawes, C. \& Roy, H.E. (2016) Design and Testing of a National Pollinator and Pollination Monitoring Framework. Final summary report to the Department for Environment, Food and Rural Affairs (Defra), Scottish Government and Welsh Government: Project WC1101. 
Casey, L.M., Rebelo, H., Rotheray, E. \& Goulson, D. (2015) Evidence for habitat and climatic specializations driving the long-term distribution trends of UK and Irish bumblebees. Diversity and Distributions, 21, 864-875.

Chandler, P., J. (2017) An Update of the 1998 Checklist of Diptera of the British Isles [updated 16 January 2017]. pp. http://www.dipteristsforum.org.uk/documents/BRITISH_ISLES_CHECKLIST.pd f.

Claussen, C. \& Stahls, G. (2007) A new species of Cheilosia Meigen from Thessaly, Greece,and its phylogenetic position (Diptera, Syrphidae). Volucella, 8, 45 - 62.

Creer, S., Deiner, K., Frey, S., Porazinska, D., Taberlet, P., Thomas, W.K., Potter, C. \& Bik, H.M. (2016) The ecologist's field guide to sequence-based identification of biodiversity. Methods in Ecology and Evolution, 7, 1008 - 1018.

deWaard, J.R., Hebert, P.D.N. \& Humble, L.M. (2011) A Comprehensive DNA Barcode Library for the Looper Moths (Lepidoptera: Geometridae) of British Columbia, Canada. PLOS ONE, 6, e18290.

Dicks, L.V., Viana, B., Bommarco, R., Brosi, B., Arizmendi, M.d.C., Cunningham, S.A., Galetto, L., Hill, R., Lopes, A.V., Pires, C., Taki, H. \& Potts, S.G. (2016) Ten policies for pollinators. Science, 354, 975.

Dillon, N., Austin, A. \& Bartowsky, E. (1996) Comparison of preservation techniques for DNA extraction from hymenopterous insects. Insect Molecular Biology, 5, 21-24.

Edmunds, M. \& Reader, T. (2014) Evidence for Batesian mimicry in a polymorphic hoverfly. Evolution, 68, 827 - 839.

Folmer, O., Black, M., Hoeh, W., Lutz, R. \& Vrijenhoek, R. (1994) DNA primers for amplification of mitochondrial cytochrome c oxidase subunit I from diverse metazoan invertebrates. Molecular Marine Biology and Biotechnology,, 3, 294299.

Geiger, M.F., Moriniere, J., Hausmann, A., Haszprunar, G., Wägele, W., Hebert, P.D.N. \& Rulik, B. (2016) Testing the Global Malaise Trap Program - How well does the current barcode reference library identify flying insects in Germany? Biodiversity Data Journal, e10671.

Gilbert, M., Moore, W., Melchior, L. \& Worobey, M. (2007) DNA Extraction from Dry Museum Beetles without Conferring External Morphological Damage. Plos One, 2. e272. https://doi.org/10.1371/journal.pone.0000272 
Godfray, H.J.C. (2007) Linneaus in the information age. Nature, 259 - 260.

Hajibabaei, M., DeWaard, J., Ivanova, N., Ratnasingham, S., Dooh, R., Kirk, S., Mackie, P. \& Hebert, P. (2005) Critical factors for assembling a high volume of DNA barcodes. Philosophical Transactions of the Royal Society B-Biological Sciences, 360, 1959-1967.

Hawlitschek, O., Morinière, J., Lehmann, G.U.C., Lehmann, A.W., Kropf, M., Dunz, A., Glaw, F., Detcharoen, M., Schmidt, S., Hausmann, A., Szucsich, N.U., CaetanoWyler, S.A. \& Haszprunar, G. (2016) DNA barcoding of crickets, katydids and grasshoppers (Orthoptera) from Central Europe with focus on Austria, Germany and Switzerland. Molecular Ecology Resources, 1037-1053. doi: 10.1111/17550998.12638 .

Hebert, P.D.N., Cywinska, A., Ball, S.L. \& deWaard, J.R. (2003) Biological identifications through DNA barcodes. Proceeding of the Royal Society of London, 270, 313 - 321.

Hendrich, L., Moriniere, J., Haszprunar, G., Hebert, P.D.N., Hausmann, A., Kohler, F. \& Balke, M. (2015) A comprehensive DNA barcode database for Central European beetles with a focus on Germany: adding more than 3500 identified species to BOLD. Molecular Ecology Resources, 15, 795-818.

Hutchinson, G.E. (1959) Homage to Santa Rosalia or Why Are There So Many Different Kinds of Animals. The American Naturalist, 93, 145 - 159.

Iftikhar, R., Ashfaq, M., Rasool, A. \& Hebert, P.D.N. (2016) DNA Barcode Analysis of Thrips (Thysanoptera) Diversity in Pakistan Reveals Cryptic Species Complexes. Plos One, 11. e0146014. https://doi.org/10.1371/journal.pone.0146014

Jauker, F. \& Wolters, V. (2008) Hoverflies are efficient pollinators of oilseed rape. Oecologia, 156, 819-823.

Ji, Y., Ashton, L., Pedley, S., Edwards, D., Tang, Y., Nakamura, A., Kitching, R., Dolman, P., Woodcock, P., Edwards, F., Larsen, T., Hsu, W., Benedick, S., Hamer, K., Wilcove, D., Bruce, C., Wang, X., Levi, T., Lott, M., Emerson, B. \& Yu, D. (2013) Reliable, verifiable and efficient monitoring of biodiversity via metabarcoding. Ecology Letters, 16, 1245-1257.

Jordaens, K., Goergen, G., Virgilio, M., Backeljau, T., Vokaer, A. \& De Meyer, M. (2015) DNA Barcoding to Improve the Taxonomy of the Afrotropical Hoverflies 
(Insecta: Diptera: Syrphidae). Plos One, 10. e0140264.

https://doi.org/10.1371/journal.pone.0140264

Lucas, A., Bull, J.C., de Vere, N., Neyland, P.J. \& Forman, D.W. (2017) Flower resource and land management drives hoverfly communities and bee abundance in seminatural and agricultural grasslands. Ecology and Evolution 7(19):8073-8086

Marcos-García, M.Á., Vujić, A., Ricarte, A. \& Ståhls, G. (2011) Towards an integrated taxonomy of the Merodon equestris species complex (Diptera: Syrphidae) including description of a new species, with additional data on Iberian Merodon. The Canadian Entomologist, 143, 332-348.

Mengual, X., Stahls, G. \& Rojo, S. (2008) Molecular phylogeny of Allograpta (Diptera, Syrphidae) reveals diversity of lineages and non-monophyly of phytophagous taxa. Molecular Phylogenetics and Evolution, 49, 715-727.

Mengual, X., Ståhls, G. \& Rojo, S. (2008) First phylogeny of predatory flower flies (Diptera, Syrphidae, Syrphinae) using mitochondrial COI and nuclear 28S rRNA genes: conflict and congruence with the current tribal classification. Cladistics, 24, 543-562.

Moriniere, J., de Araujo, B.C., Lam, A.W., Hausmann, A., Balke, M., Schmidt, S., Hendrich, L., Doczkal, D., Fartmann, B., Arvidsson, S. \& Haszprunar, G. (2016) Species Identification in Malaise Trap Samples by DNA Barcoding Based on NGS Technologies and a Scoring Matrix. Plos One, 11. e0155497. https://doi.org/10.1371/journal.pone.0155497

Morinière, J., Hendrich, L., Balke, M., Beermann, A.J., König, T., Hess, M., Koch, S., Müller, R., Leese, F., Hebert, P.D.N., Hausmann, A., Schubart, C.D. \& Haszprunar, G. (2017) A DNA barcode library for Germany's mayflies, stoneflies and caddisflies (Ephemeroptera, Plecoptera and Trichoptera). Molecular Ecology Resources, doi: 10.1111/1755-0998.12683.

Nabhan, G.P. \& Buchmann, S.L. (1997) Services Provided by Pollinators. Nature's Services: Societal Dependence on Natural Ecosystems (ed. G.C. Daily). Island Press, Washington DC.

Ollerton, J., Price, V., Armbruster, W.S., Memmott, J., Watts, S., Waser, N.M., Totland, Ø., Goulson, D., Alarcón, R., Stout, J.C. \& Tarrant, S. (2012) Overplaying the role of honey bees as pollinators: a comment on Aebi and Neumann (2011). Trends in Ecology \& Evolution, 27, 141-142. 
Park, D.S., Foottit, R., Maw, E. \& Hebert, P.D.N. (2011) Barcoding Bugs: DNA-Based Identification of the True Bugs (Insecta: Hemiptera: Heteroptera). PloS One, 6.

Pohjoismaki, J.L.O., Kahanpaa, J. \& Mutanen, M. (2016) DNA Barcodes for the Northern European Tachinid Flies (Diptera: Tachinidae). Plos One, 11. e0164933. https://doi.org/10.1371/journal.pone.0164933

Prodorutti, D. \& Frilli, F. (2008) Entomophilous pollination of raspberry, red currant and highbush blueberry in a mountain area of Friuli-Venezia Giulia (north-eastern Italy). Proceedings of the Ixth International Rubus and Ribes Symposium (eds P. Banados \& A. Dale), pp. 429-434.

Pu, D.Q., Liu, H.L., Gong, Y.Y., Ji, P.C., Li, Y.J., Mou, F.S. \& Wei, S.J. (2017) Mitochondrial genomes of the hoverflies Episyrphus balteatus and Eupeodes corollae ( Diptera: Syrphidae), with a phylogenetic analysis of Muscomorpha. Scientific Reports, 7 doi: 10.1038/srep443000.

Radenkovic, S., Vujic, A., Stahls, G., Perez-Banon, C., Rojo, S., Petanidou, T. \& Simic, S. (2011) Three new cryptic species of the genus Merodon Meigen (Diptera: Syrphidae) from the island of Lesvos (Greece). Zootaxa, 2735:35-56 .

Radisic, P., Papadopoulos, A., Vujic, A. \& Simic, S. (2001) Pollen feeding of Cheilosia albipila Meigen, 1838 (Diptera: Syrphidae). Acta Entomologica Serbica, 6, 83 92.

Ramsden, M., Menendez, R., Leather, S. \& Wäckers, F. (2016) Do natural enemies really make a difference? Field scale impacts of parasitoid wasps and hoverfly larvae on cereal aphid populations. Agricultural and Forest Entomology, DOI: 10.1111/afe.12191.

Raupach, M.J., Hannig, K., Moriniere, J. \& Hendrich, L. (2016) A DNA barcode library for ground beetles (Insecta, Coleoptera, Carabidae) of Germany: The genus Bembidion Latreille, 1802 and allied taxa. Zookeys, 592, 121-141.

Raupach, M.J., Hendrich, L., Kuechler, S.M., Deister, F., Moriniere, J. \& Gossner, M.M. (2014) Building-Up of a DNA Barcode Library for True Bugs (Insecta: Hemiptera: Heteroptera) of Germany Reveals Taxonomic Uncertainties and Surprises. Plos One, 9. e106940. https://doi.org/10.1371/journal.pone.0106940

Raymond, L., Plantegenest, M. \& Vialatte, A. (2013) Migration and dispersal may drive to high genetic variation and significant genetic mixing: the case of two 
agriculturally important, continental hoverflies (Episyrphus balteatus and Sphaerophoria scripta). Molecular Ecology, 22, 5329-5339.

Rotheray, G.E. (1993) A Colour Guide to Hoverfly Larvae (Diptera, Syrphidae). Derek Whiteley, Sheffield, England.

Rotheray, G.E. \& Gilbert, F. (2011) The Natural History of Hoverflies. Forrest Text, Cardigan.

Skevington, J.H. \& Thompson, F.C. (2012) Review of New World Sericomyia (Diptera: Syrphidae), including description of a new species. Canadian Entomologist, 144, 216-247.

Ssymank, A. \& Gilbert, F. (1993) Anemophilous pollen in the diet of syrphid flies with special reference to the leaf feeding strategy occurring in Xylotini (Diptera: Syrphidae). Deutsche Entomologische Zeitschrift, 40, 245 - 258.

Stahls, G. \& Barkalov, A.V. (2017) Taxonomic review of the Palaearctic species of the Cheilosia caerulescens-group (Diptera, Syrphidae). Zookeys, 662, 137-171.

Stahls, G., Hippa, H., Rotheray, G., Muona, J. \& Gilbert, F. (2003) Phylogeny of Syrphidae (Diptera) inferred from combined analysis of molecular and morphological characters. Systematic Entomology, 28, 433-450.

Stahls, G. \& Nyblom, K. (2000) Phylogenetic analysis of the genus Cheilosia (Diptera, Syrphidae) using mitochondrial COI sequence data. Molecular Phylogenetics and Evolution, 15, 235-241.

Stahls, G., Vujic, A., Perez-Banon, C., Radenkovic, S., Rojo, S. \& Petanidou, T. (2009) COI barcodes for identification of Merodon hoverflies (Diptera, Syrphidae) of Lesvos Island, Greece. Molecular Ecology Resources, 9, 1431-1438.

Stubbs, A.E. \& Falk, S.J. (2002) British Hoverflies. An illustrated identification guide. BENHS, Reading.

Taberlet, P., Coissac, E., Pompanon, F., Brochmann, C. \& Willerslev, E. (2012) Towards next-generation biodiversity assessment using DNA metabarcoding. Molecular Ecology, 21, 2045 - 2250.

Tautz, D., Arctander, P., Minelli, A., Thomas, R.H. \& Vogler, A.P. (2003) A plea for DNA taxonomy. Trends in Ecology and Evolution, 18, 70 - 74.

Vujić, A., Ståhls, G., Ačanski, J., Bartsch, H., Bygebjerg, R. \& Stefanović, A. (2013) Systematics of Pipizini and taxonomy of European Pipiza Fallén: molecular and morphological evidence (Diptera, Syrphidae). Zoologica Scripta, 42, 288-305. 
Wardhaugh, C.W. (2015) How many species of arthropods visit flowers? ArthropodPlant Interactions, 9, 547-565.

Yu, D.W., Ji, Y., Emerson, B.C., Wang, X., Ye, C., Yang, C. \& Ding, Z. (2012) Biodiversity soup: metabarcoding of arthropods for rapid biodiversity assessment and biomonitoring. Methods in Ecology and Evolution, 3, 613 - 623.

Zeale, M.R.K., Butlin, R.K., Barker, G.L.A., Lees, D.C. \& Jones, G. (2011) Taxonspecific PCR for DNA barcoding arthropod prey in bat faeces. Molecular Ecology Resources, 11, 236-244. 


\section{Chapter 5}

\section{Generalisation and specialisation in hoverfly}

\section{(Syrphidae) grassland pollen transport networks}

\section{revealed by DNA metabarcoding.}

Andrew Lucas, Owen Bodger, Berry J Brosi, Col R. Ford, Dan W. Forman,

Carolyn Greig, Matthew Hegarty, Penelope J. Neyland, Natasha de Vere

(NB: following peer review, this chapter was published in an amended form as Lucas et al (2018) Generalisation and specialisation in hoverfly (Syrphidae) grassland pollen transport networks revealed by DNA metabarcoding. Journal of Animal Ecology, https://doi.org/10.1111/13652656.12828)

Andrew Lucas conceived the study, undertook fieldwork, DNA sample preparation, statistical analysis, and led writing of the manuscript. Owen Bodger and Berry Brosi performed statistical analysis and drafted the manuscript. Col Ford undertook data analysis and figure design. Dan Forman and Penny Neyland DF and PN helped to plan the study, and draft the manuscript. Carolyn Greig designed the pollen removal protocol, and drafted the manuscript. Matt Hegarty assisted with development of NGS metabarcoding protocols and creation of the sequencing libraries, performed the NGS runs and assisted with data analysis. Natasha de Vere conceived and designed the experiments, acquired and analysed the data, and drafted the manuscript. 


\section{Summary}

1. Pollination by insects is a key ecosystem service, and important to wider ecosystem function. Most species-level pollination networks studied have a generalised structure, with plants having several potential pollinators, and pollinators in turn visiting a number of different plant species. This is in contrast to a plant's need for efficient conspecific pollen transfer.

2. The aim of this study was to investigate the structure of pollen transport networks at three levels of biological hierarchy: community, species, and individual. We did this using hoverflies in the genus Eristalis, a key group of non-Hymenopteran pollinators.

3. We constructed pollen transport networks using DNA metabarcoding to identify pollen. We captured hoverflies in conservation grasslands in west Wales, UK, removed external pollen loads, sequenced the pollen DNA on the Illumina MiSeq platform using the standard plant barcode $r b c L$, and matched sequences using a pre-existing plant DNA barcode reference library.

4. We found that Eristalis hoverflies transport pollen from 65 plant taxa, more than previously appreciated. Networks were generalised at the site and species level, suggesting some degree of functional redundancy, and were more generalised in late summer compared to early summer. In contrast, pollen transport at the individual level appears to be relatively specialised. The pollen loads of individual hoverflies came predominantly from single plant taxa, suggesting some degree of specialisation by individuals. However, individual hoverflies did become more generalised in late summer, possibly in response to an increase in floral resources. Rubus fruticosus agg. and Succisa pratensis were key plant species for hoverflies at our sites.

5. Our results contribute to resolving the apparent paradox of how generalised pollinator networks can provide efficient pollination to plant species. Generalised hoverfly pollen transport networks may result from a varied range of short-term specialised feeding bouts by individual insects. The generalisation and functional redundancy of Eristalis pollen transport networks may increase the stability of the pollination service they deliver. 


\section{Introduction}

The structure and function of pollination networks has been the subject of considerable research interest (Petanidou et al. 2008; Jordano 2016; Nicolson \& Wright 2017). Despite examples of remarkable mutualisms between specific plants and their pollinator species (Stokl et al. 2011; Johnson, Hollens \& Kuhlmann 2012), plant-pollinator networks often have a generalised structure (Waser et al. 1996; Memmott 1999; Bascompte et al. 2003) in which plant species are visited by numerous pollinator taxa, and pollinators in turn visit a number of plant species. Pollination is a key ecosystem service (IPBES 2016) that has significant economic value as well as facilitating wider ecosystem function (Gill et al. 2016; Potts et al. 2016). Understanding the structure of plant-pollinator networks is important to safeguarding the provision of this ecosystem service, because generalised networks may be more robust to a number of environmental stressors, including climate change (Memmott et al. 2007; Gilman et al. 2012), species extinctions and invasive species (Memmott, Waser \& Price 2004; Kaiser-Bunbury et al. 2010), and to the impact of habitat management (Vanbergen et al. 2014).

However, generalised pollination networks appear to be contrary to the need of plants for efficient conspecific pollen transfer to achieve pollination (Waser 1986). It has been suggested that such networks can be both generalised and specialised at different levels of biological hierarchy, with individual insects engaging in short-term specialised feeding bouts, and therefore efficiently moving pollen between plant conspecifics, whilst networks at the species and community level remain generalised (Ollerton 1996; Armbruster 2016; Brosi 2016). Addressing this issue requires the investigation of individual pollinator behaviour, but existing techniques, such as following insects in the field (Ambrosino et al. 2006; Brosi \& Briggs 2013), or morphologically identifying pollen grains carried by insects (Golding \& Edmunds 2003), have limitations. In particular, the accurate visual identification of pollen requires considerable skill (Bruni et al. 2015; Hawkins et al. 2015) with some plant species groups being difficult to distinguish, even by experts (Galimberti et al. 2014).

Many studies of pollination networks have focussed on bees (Hymenoptera) (Ballantyne, Baldock \& Willmer 2015; Tucker \& Rehan 2016). However, hoverflies (Syrphidae), 
which, as adults, feed almost exclusively on nectar and pollen, are also pollinators of a wide range of plants (Gyan \& Woodell 1987; Woodcock et al. 2014), including crop species such as oilseed rape Brassica napa (Stanley, Gunning \& Stout 2013). Wild pollinators, including hoverflies, have been shown to be more effective pollinators (in terms of fruit set) than honey bees in a range of crop systems (Garibaldi et al. 2013), and the species diversity of wild pollinators may make them more resilient to temporal environmental change than managed honey bees (Rader et al. 2015). Nonetheless, there remain key gaps in the pollination science evidence-base, particularly relating to which insects pollinate which wild plants (Dicks et al. 2013).

DNA metabarcoding, the use of next-generation DNA sequencing to identify species from mixed samples (Creer et al. 2016), has great potential in the study of insect pollen transport (Clare et al. 2013). This approach compares samples of mixed DNA sequences recovered from pollen with a library of plant species sequences (Hawkins et al. 2015). DNA barcodes have been successfully recovered from pollen carried by bees (Wilson et al. 2010; Bell et al. 2017; de Vere et al. 2017). DNA metabarcoding therefore has the potential to offer an insight into pollen transport by hoverflies, by allowing the identification of mixed pollen samples from individual hoverflies without requiring specialist palynological expertise (Bell et al. 2016).

Here, we investigate the pollen transport network of Eristalis hoverflies, a genus widely distributed across the Holarctic. We carried out this study in fen-meadow grasslands, a floristically-rich habitat of conservation importance in lowland Wales, UK (Blackstock, Howe \& Stevens 2010). We retrieved and isolated pollen DNA carried on the bodies of hoverfly specimens, and sequenced and matched sequences to a pre-existing library to identify the pollen plant taxa (de Vere et al. 2012). We also quantified the flower resource available to hoverflies in these botanically diverse habitats. From these data, we constructed hoverfly pollen transport networks that describe specialization at the level of the overall network $\left(H_{2}{ }^{\prime}\right)$ and species ( $\left.d^{\prime}\right)$ level (Bluthgen, Menzel \& Bluthgen 2006). Using the relative proportions of pollen sequence reads, we have investigated the degree of specialisation shown by individual insects. This has allowed us to investigate hoverfly pollen transport from whole networks to individuals and relate these results to changes in flower resource availability. We address the following specific research questions: 
1. What plant pollens are Eristalis hoverflies transporting, and how do the proportions of different pollen species change during the summer flight period? We predict that hoverflies carry pollen reflecting seasonal variation in floral resource availability, and become less specialised later in the season as more pollen resources became available.

2. How are Eristalis pollen transport networks structured? Our prediction is that, similar to pollination networks studied previously, they would have a generalised structure at the whole network and species level.

3. Are individual insects specialised? Our prediction here is that, given the evidence of floral constancy found by direct observation of hoverflies during foraging bouts (Goulson \& Wright 1998), some degree of specialisation will be reflected in the pollen loads of individual insects.

\section{Materials and Methods}

\section{Field Collection of Hoverflies}

The study took place during 2014 at four grassland sites of high conservation importance in west Wales, United Kingdom. We collected Eristalis hoverflies at these locations (referred to as 'CAD', 'LLC', 'RHC' and 'TRE'), where the National Vegetation Classification community Molinia caerulea - Cirsium dissectum fen-meadow (CirsioMolinietum caerulae) (Rodwell et al. 1991) was present (for full site information, see Appendix 1). Each site consisted of a single field, surrounded by hedgerows. Collection occurred in two time periods: 'early' ( $1^{\text {st }}$ June to July $\left.15^{\text {th }}\right)$ and 'late' (July $16^{\text {th }}$ to August $\left.31^{\text {st }}\right)$. To ensure the insects captured were representative of the site as a whole, a series of transects 20m apart were walked across each site, during which Eristalis hoverflies were actively collected using a hand-held net. Transects were walked continuously, repeating them as necessary, with each site searched for approximately three hours in each time period (early and late season). Insects were stored individually in sterile $1.5 \mathrm{ml}$ tubes at $20^{\circ} \mathrm{C}$ prior to pollen removal.

\section{Recording of plant species-richness and herb flower resource}


We used existing grassland survey information in Bevan et al. (2006), together with records of species present in the hedgerows, to create a list of plant species (and therefore a measure of plant species richness) for each site.

To measure the grassland herb flower resource (here termed 'flower unit score') we placed a 50m x 50m plot approximately centrally in each site. This size was selected as the largest plot size that could be used on the smallest site. Within the plot, we set up 30 randomly located $1 \mathrm{~m}^{2}$ quadrats, within which we recorded all the plant species in flower, excluding grasses and sedges. We also recorded the number of floral units within the quadrat. For most plant species, a floral unit corresponds to a single flower, but for Apiaceae species an inflorescence was counted as one flower unit, and for Dactylorhiza spp., Narthecium ossifragum and Calluna vulgaris, a single flowering stem or spike was counted as one flower unit. These measurements are similar to the 'blossom units' described by Dicks et al. (2002), based on a floral unit that a medium-sized bee has to fly, rather than walk, between. We recorded the flowers twice at each site, once in the early period, and once in the late.

\section{Pollen Removal}

We removed external pollen from insects, first via an initial washing of insects in the tube in which the insect had been placed in the field. The fly was immersed in $1 \mathrm{ml}$ of a $1 \%$ sodium dodecyl sulphate (SDS) and $2 \%$ poly-vinyl pyrrolidinone (PVP) solution in water. The tube was shaken vigorously by hand for 1 minute, and then centrifuged briefly to ensure that the insect was fully immersed in the liquid. It was then allowed to stand at room temperature for 5 minutes. The tube was then shaken vigorously by hand for 20 seconds. The fly was removed using forceps to a clean $1.5 \mathrm{ml}$ tube and frozen at $20^{\circ} \mathrm{C}$ for subsequent species identification. The tube containing the detergent and pollen was centrifuged at $13000 \mathrm{rpm}$ for 5 minutes.

\section{DNA extraction}

We used the DNeasy plant mini kit (Qiagen) to extract DNA. The supernatant was discarded and the pellet suspended in $400 \mu \mathrm{L}$ AP1 and $80 \mu \mathrm{L}$ proteinase $\mathrm{K}(1 \mathrm{mg} / \mathrm{ml})$. This was incubated for 60 minutes at $65^{\circ} \mathrm{C}$ in a water bath and then disrupted using a TissueLyser II (Qiagen) for 4 minutes at $30 \mathrm{~Hz}$ with $3 \mathrm{~mm}$ tungsten carbide beads. The 
subsequent steps were followed according to the manufacturer's instructions, with the exception that QIAshredder column and second wash stage were omitted.

\section{Amplification and Sequencing: Illumina Miseq}

We amplified the DNA using the $r b c L$ DNA barcode marker region (CBOL Plant Working Group et al. 2009; Bell, Loeffler \& Brosi 2017). Two rounds of PCR were carried out: a primary tailed amplification of the $r b c L$ region, followed by a second round of amplification that added the Illumina Nextera index adaptor sequences so that samples could be processed on Illumina platforms and be subsequently separated via bioinformatic processing. We initially amplified the samples using the universal primers rbcLaf and rbcLr506 (de Vere et al. 2012), to which adaptor 5' overhangs had been added:

(rbcLaf+adaptor:

TCGTCGGCAGCGTCAGATGTGTATAAGAGACAGATGTCACCACAAACAGAGA CTAAAGC

rbcLr506+adaptor:

GTCTCGTGGGCTCGGAGATGTGTATAAGAGACAGAGGGGACGACCATACTTG TTCA).

We performed the PCR using a final volume of $20 \mu \mathrm{l}$. A mix of $10 \mu \mathrm{l}$ of $2 \mathrm{x}$ Phusion Mastermix (New England Biolabs), $0.4 \mu \mathrm{l}$ of forward primer (rbcLa-F), $0.4 \mu \mathrm{l}$ of reverse primer (rbcL506), and $7.2 \mu \mathrm{l}$ of molecular biology grade water was made, to which $2.0 \mu \mathrm{l}$ of template DNA was added. The PCR conditions were: $95^{\circ} \mathrm{C}$ for 2 minutes; $95^{\circ} \mathrm{C}$ for 30 seconds, $50^{\circ} \mathrm{C}$ for 1 minute 30 seconds, $72^{\circ} \mathrm{C}$ for 40 seconds ( 35 cycles), $72^{\circ} \mathrm{C}$ for 5 minutes, $30^{\circ} \mathrm{C}$ for 10 seconds. PCR products were visualised using agarose gel electrophoresis to confirm successful amplification.

We purified the products from the first PCR following IIlumina's 16S Metagenomic Sequencing Library Preparation protocol (Illumina 2013) using Agencourt AMPure XP beads (Beckman Coulter). The Index PCR stage (following the Illumina protocol) used a $25 \mu 1$ reaction $(12.5 \mu \mathrm{l}$ of $2 \mathrm{x}$ Phusion Mastermix, $2.5 \mu \mathrm{l}$ of Nextera XT i7 Index Primer, $2.5 \mu 1$ of Nextera XT i5 Index Primer, $5 \mu 1$ of PCR grade water, and $2.5 \mu 1$ of purified first-round PCR product). PCR clean-up 2 of the Illumina protocol was then followed, 
cleaning $20 \mu 1$ of Indexed PCR product, with a 1:0.8 ratio of product to AMPure XP beads.

We quantified the amplified products using a Qubit fluorescence spectrophotometer (Life Technologies) and pooled at equal concentrations to produce the final library. This was again quantified via Qubit to determine concentration and adjusted to $10 \mathrm{nM}$ concentration with $0.1 \mathrm{M}$ Tris- $\mathrm{HCl} / 0.01 \%$ Tween 20 solution prior to sequencing on an Illumina MiSeq platform. Library denaturation and sample loading steps followed the Illumina protocol: sample was loaded at 3pM concentration with $20 \%$ PhiX control spike and paired-end sequences generated in $2 \times 300 \mathrm{bp}$ format.

\section{Data Analysis}

A data analysis pipeline was created to process the Illumina sequence reads and to match them to known taxa within a local reference database. Files containing the sequence reads used in this study are available through the NCBI sequence read archive (SRA accession SRP076527). The source code and tools used for the pipeline are available on github at https://github.com/colford/nbgw-plant-illumina-pipeline. Sequences were quality trimmed and then merged with only sequences greater than $450 \mathrm{bp}$ used in downstream analysis.

A local BLAST database was created from chloroplast sequence data from GenBank which included $r b c L$ sequences obtained from the Barcode Wales project, providing $98 \%$ coverage for the native flowering plants of Wales (de Vere et al. 2012). DNA sequences from the pollen samples were scored against the database using MegaBLAST. If the sequence top bit score matched to a single species, then the sequence was identified to that species. If the top bit score was the same for different species belonging to the same genus, then the result was given to genus. If the top bit score belonged to multiple genera within the same family then a family level designation was made. Sequences blasting to multiple families were considered to be unknown (Hawkins et al. 2015; de Vere et al. 2017).

Results for each pollen sample were manually filtered so that only species recorded within the UK (Stace 2010) were retained. The number of sequences for each insect was then converted to a proportion (\%), to control for differences in DNA amplification between samples in the initial PCR. These results can be influenced by differences in the 
amount of pollen produced by different plants and biases introduced during DNA extraction, PCR and sequencing. To avoid these biases, pollen results were used on a presence/absence basis for the network analysis, with the percentage data used as a semiquantitative measure of DNA amount to investigate the proportions of pollen carried by individuals.

\section{Network Analysis}

Interaction networks were analysed using the Bipartite Package (v. 2.05) (Dormann, Gruber \& Frund 2008), and binomial-errors mixed-effects models using the lme4 package (Bates et al. 2015) in R version 3.0.1 (R Core Team 2014),

We calculated two metrics of network specialization (Bluthgen, Menzel \& Bluthgen 2006; Baldock et al. 2015; Ballantyne, Baldock \& Willmer 2015). These were network specialisation $\left(\mathrm{H}_{2}{ }^{\prime}\right)$, which represents the overall level of specialisation of all species in a network, and varies from 0 (complete generalisation) to 1 (complete specialisation); and $d$, which measures how exclusive a given species' interactions are compared to the other species in a network, and varies from 0 (no exclusivity) to 1 (completely exclusive).

To investigate the influence of time period, and hoverfly sex on individual specialisation, we used a binomial-errors mixed-effects model. Hoverflies were placed in two categories: predominantly 'single plant visitors', defined as individuals where the proportion of sequences of the greatest pollen taxon was $90 \%$ or above, and 'multi-plant visitors', where the proportion was below $90 \%$. The threshold of $90 \%$ was selected because of the possibility of hoverflies acquiring heterospecific pollen from a plant deposited by a previous visitor, or windblown pollen present in the wider environment. It was therefore unrealistic to expect $100 \%$ of pollen carried by a hoverfly to come from one plant taxon group. The response variable was single versus multi-plant visitors, with time period and hoverfly sex as fixed effects. Site and species were included as random effects.

\section{Results}

\section{Overview}


Pollen sequences from Illumina MiSeq were recovered from 180 out of 192 individual hoverfly samples (55 during the early period and 125 in the late period). A total of 2,349,247 (148,216 from early period, and 2,201,031 from late period) sequences over $450 \mathrm{bp}$ in length could be attributed to tagged sequences of $r b c L$. Of these, 2,330,020 (99.2\%) could be identified to plants at species, genus or family level (see Appendix 2). A total of 65 plant taxonomic groups were identified consisting of 24 species, 27 genera and 14 tribes and families, ranging from 31 at site TRE to 39 at site LLC. Hoverflies were identified to six species: E. arbustorum, E. horticola, E. intricaria, E. nemorum, E. pertinax and E. tenax.

\section{What plant pollens are Eristalis hoverflies transporting?}

Botanical surveys of sample sites showed that plant species-richness varied from 63 (site CAD) to 83 species (site RHC). Flower unit score, recorded twice at each site, ranged from 20 (site LLC early period) to 631 (site RHC early period) (table 1). Flower unit scores rose at three out of four sites from the early to the late period. Flower unit scores fell at one site (RHC), although it should be noted that resources at this site in early summer were exceptionally high relative to the other sites, and the value in late summer was comparable to sites LLC and TRE. 
Table 1. The total number of plant taxonomic groups recorded from pollen carried by Eristalis hoverflies at four sites ('CAD', 'LLC', 'RHC' and 'TRE') in west Wales during 2014, with site plant species-richness and flower unit score (see text for definition) between June 1 and July 15 (early) and July 16 and August 31 (late).

\begin{tabular}{|l|c|c|c|c|}
\hline Site & CAD & LLC & RHC & TRE \\
\hline No. Pollen taxa recorded & 32 & 39 & 38 & 31 \\
\hline Site plant species richness & 63 & 75 & 83 & 66 \\
\hline Flower unit score Early & 168 & 20 & 631 & 75 \\
\hline Flower unit score Late & 372 & 100 & 96 & 99 \\
\hline
\end{tabular}

When all sites were considered together, during the early period the most frequently recovered pollen originated from Rubus fruticosus agg., Sambucus nigra, Apiaceae, Ranunculus spp., and Cardueae (thistles and knapweeds). In the late period, the plant pollens present on most Eristalis hoverflies were Cardueae, R. fruticosus agg., Succisa pratensis, Filipendula ulmaria, and Apiaceae (see Appendix 2). Whilst the sites CAD, LLC and TRE were similar in the numbers of different pollen taxa present, site RHC was more plant species-rich, and had a greater variety of pollen taxa carried by hoverflies. This was particularly noticeable in the early period, when $R$. fruticosus agg. was the predominant taxon at CAD, LLC and TRE, but at RHC there was a mix of pollens, with Apiaceae, R. fruticosus agg., S. nigra and Senecio spp. being the principal taxa recovered from hoverflies (Figure $1-3$ ). 

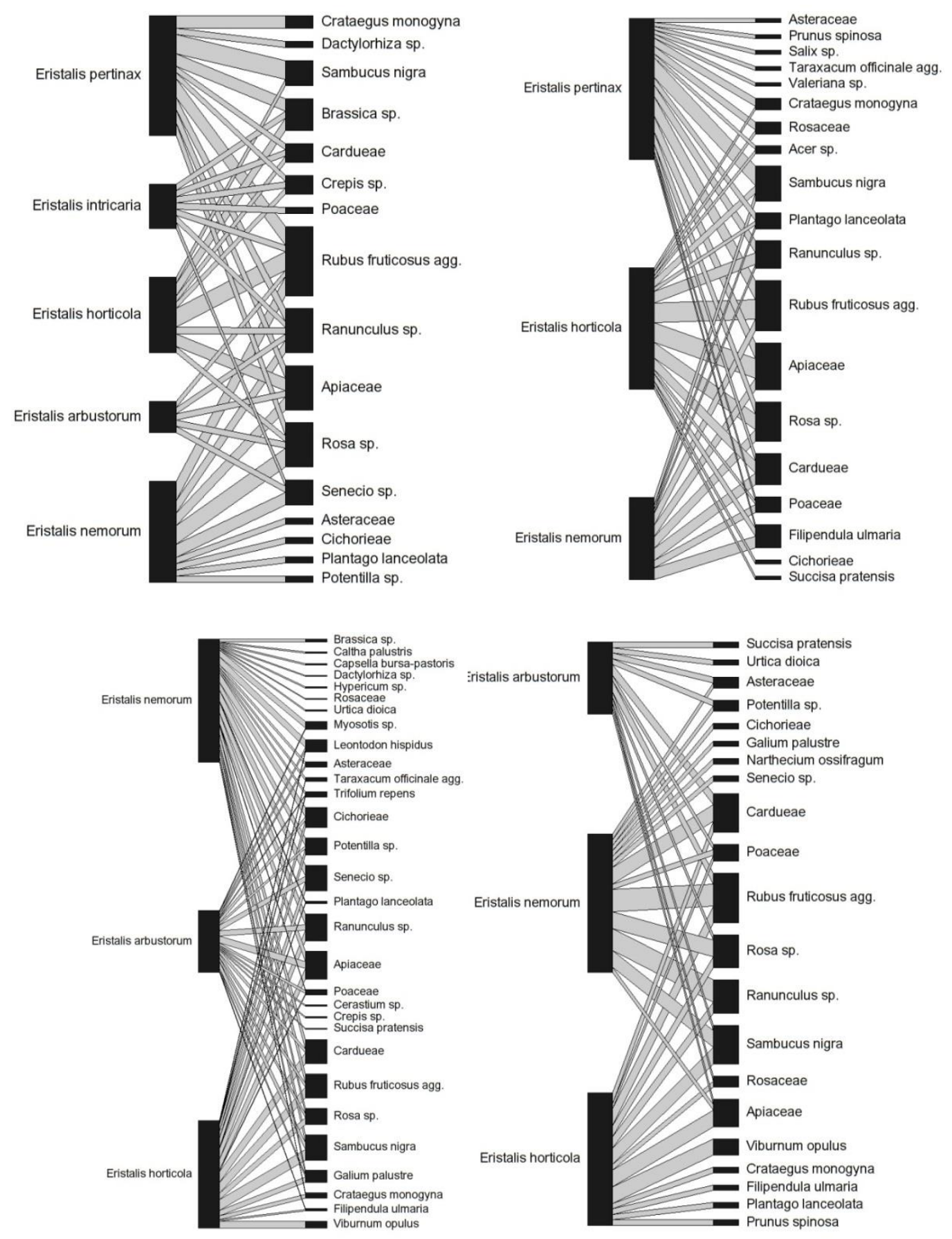

Figure 1. Eristalis hoverfly pollen transport networks at four grassland sites CAD (top left), LLC (top right, RHC (bottom left) and TRE (bottom right). Insects collected between June 12014 and July 152014 ('early'). 

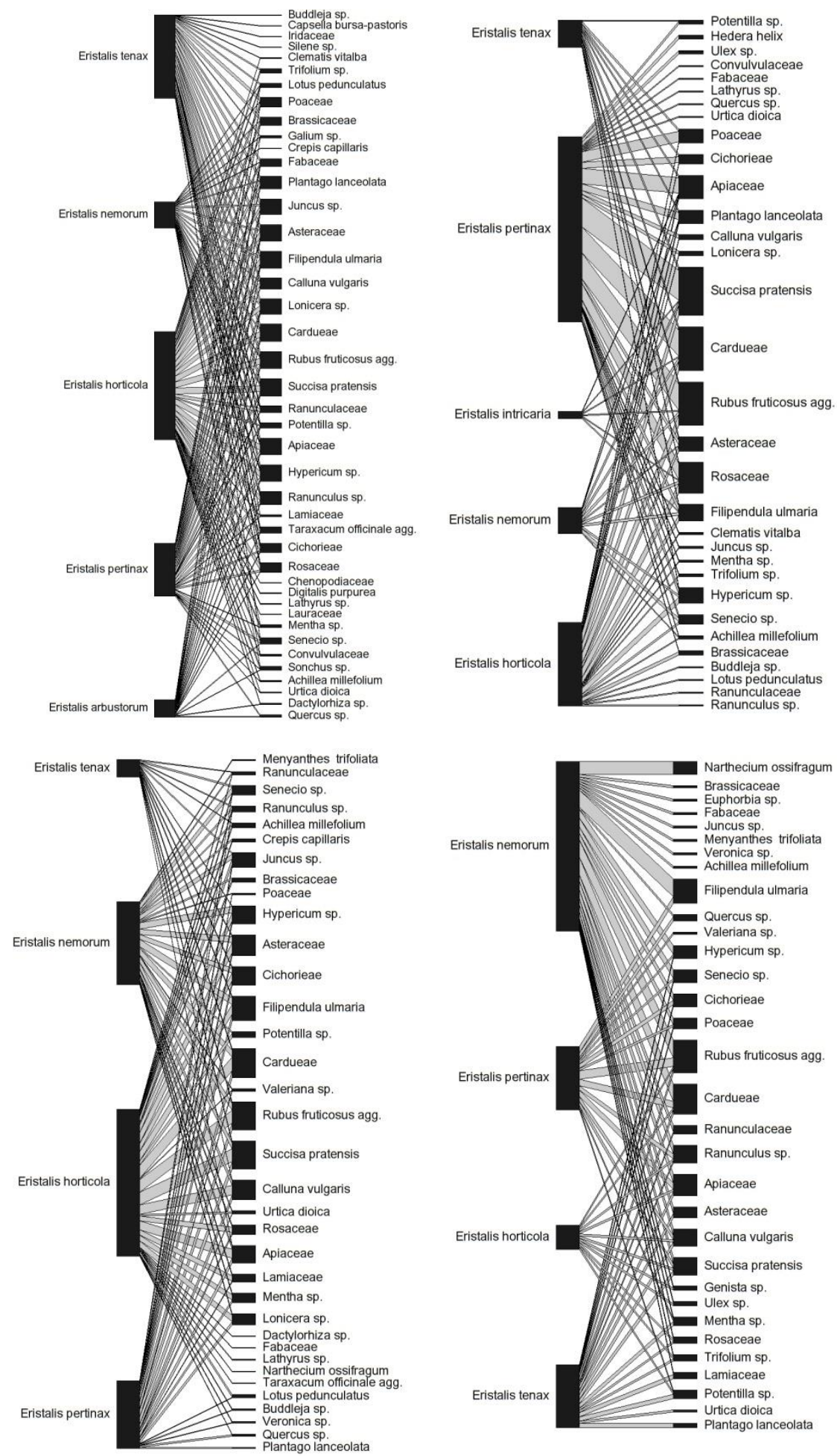

Figure 2. Eristalis hoverfly pollen transport networks at four grassland sites CAD (top left), LLC (top right, RHC (bottom left) and TRE (bottom right). Insects collected between July 16 and August 312014 ('late'). 


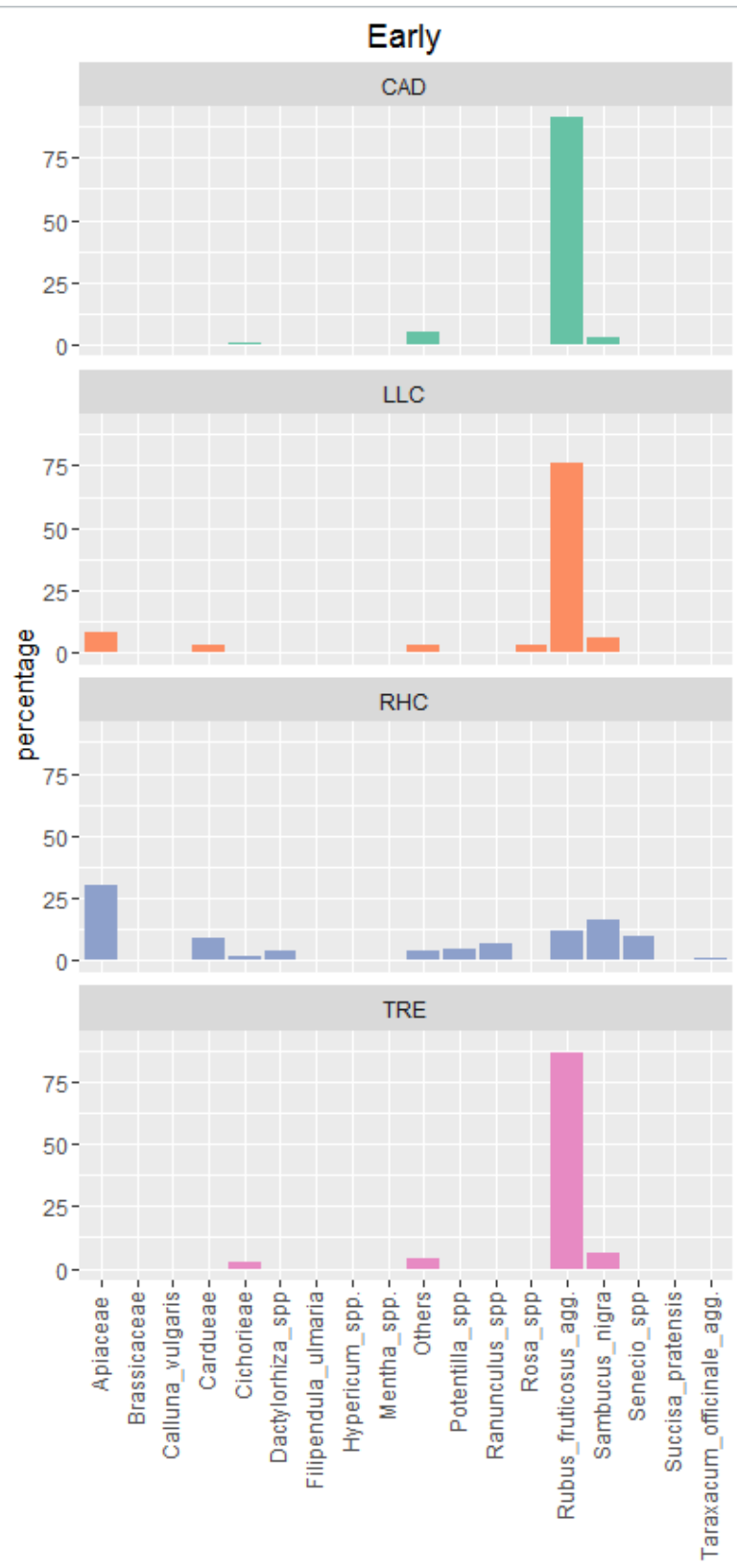

species
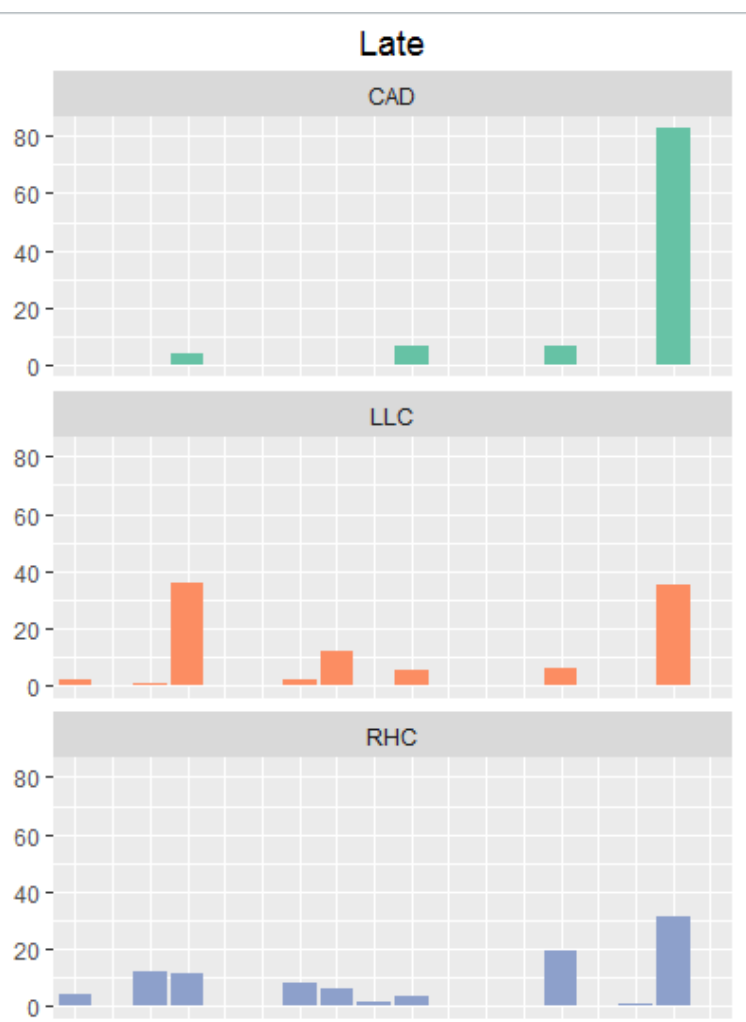

TRE

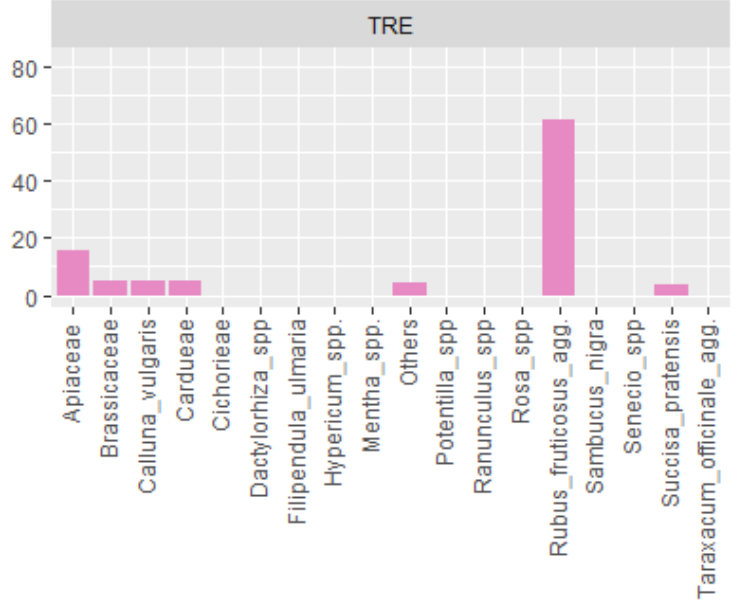

species

Figure 3. Proportions (\%) of pollen DNA sequences from hoverflies on four grasslands.

Early - insects collected between 1 June and 15 July. Late - insects collected between 16 July and 31 August. Pollen taxa contributing 1\% or less to the total are combined into the 'others' category. 


\section{How are Eristalis pollen transport networks structured?}

The numbers of Eristalis individuals identified, together with network metrics, $\mathrm{H}_{2}$ ' and $d^{\prime}$, are shown in table 2. The network specialisation metrics $H_{2}{ }^{\prime}$ indicate that networks were generalised, with all values below 0.3 (Bluthgen, Menzel \& Bluthgen 2006). $H_{2}$ ' values ranged from 0.071 (LLC late) to 0.298 (TRE early). Values of $H_{2}$ ' fell from the early period to the late period at all sites, indicating that network generalisation increased during the summer.

Values of the species level metric $d^{\prime}$ 'at all sites were low (table 2), ranging from $0.00(E$. intricaria at site CAD late) to 0.32 (E. nemorum at site CAD early). This indicates that very few hoverfly - plant interactions were exclusive to a particular hoverfly species at any site in either time period. When all sites in the early period are considered, $d$ 'values ranged from 0.01 to 0.32 , whilst in the late period, they ranged from 0.00 to 0.20 . When the degree of specialisation in a species at the same site between time periods was considered, almost all values of $d$ ' fell from early summer to late summer, with the exception of E. horticola at site LLC and at TRE. 
Table 2. Values of network metric $H_{2}^{\prime}$ and the species interaction specialisation metric $d$ ' for Eristalis $\mathrm{h}$ west Wales from June 1 - July 15 (early) and July 16 - August 31 (late) in 2014.

\begin{tabular}{|c|c|c|c|c|c|c|c|c|c|c|c|}
\hline & \multicolumn{8}{|c|}{ Early } & & & \\
\hline & \multicolumn{2}{|c|}{ CAD } & \multicolumn{2}{|c|}{ LLC } & \multicolumn{2}{|c|}{ RHC } & \multicolumn{2}{|c|}{ TRE } & \multicolumn{2}{|c|}{ CAD } & \multirow{2}{*}{$\begin{array}{c}\text { LL } \\
0.0\end{array}$} \\
\hline Network specialisation $\boldsymbol{H}_{2}$ & \multicolumn{2}{|c|}{0.279} & \multicolumn{2}{|c|}{0.133} & \multicolumn{2}{|c|}{0.130} & \multicolumn{2}{|c|}{0.298} & \multicolumn{2}{|c|}{0.117} & \\
\hline Species specialisation $d^{\prime}$ & d' & $\mathbf{n}$ & d' & $\mathbf{n}$ & d' & $\mathbf{n}$ & d' & $\mathbf{n}$ & d' & $\mathbf{n}$ & d' \\
\hline Eristalis arbustorum & 0.02 & 1 & & 0 & 0.09 & 5 & 0.17 & 2 & & 0 & 0.09 \\
\hline Eristalis horticola & 0.08 & 3 & 0.01 & 5 & 0.11 & 8 & 0.15 & 3 & 0.08 & 9 & 0.03 \\
\hline Eristalis intricaria & 0.24 & 1 & & 0 & & 0 & & 0 & 0.00 & 1 & \\
\hline Eristalis pertinax & 0.15 & 3 & 0.05 & 6 & & 0 & & 0 & 0.06 & 25 & 0.04 \\
\hline Eristalis nemorum & 0.32 & 3 & 0.11 & 3 & 0.08 & 8 & 0.15 & 4 & 0.09 & 3 & 0.04 \\
\hline Eristalis tenax & & 0 & & 0 & & 0 & & 0 & 0.08 & 3 & 0.06 \\
\hline
\end{tabular}




\section{Are individual hoverflies specialised?}

Results from the binomial-errors mixed-effects model showed that multi-species plant visitors (defined as individuals for which fewer than $90 \%$ of pollen sequences came from a single plant taxon) were significantly more common in the late vs the early time period ( $\mathrm{z}=2.712, P<0.01)$, but that sex was not significantly related to the proportion of multispecies visits.

The range of proportions of sequences from a single plant taxon coming from individual hoverflies is shown in figure 4. Most of the pollen on hoverfly individuals came from a single plant taxon. In the early period, 22 out of 55 (40\%) hoverflies had $90 \%$ or more of their pollen sequences coming from a single plant taxon, and 37 out of $55(67 \%)$ had at least $60 \%$ of their pollen sequences from a single plant taxon. In the late period, 30 out of $125(24 \%)$ had $90 \%$ or more of their pollen sequences coming from a single plant taxon, and 87 out of $125(70 \%)$ had at least $60 \%$ of their pollen sequences from a single plant taxon. 


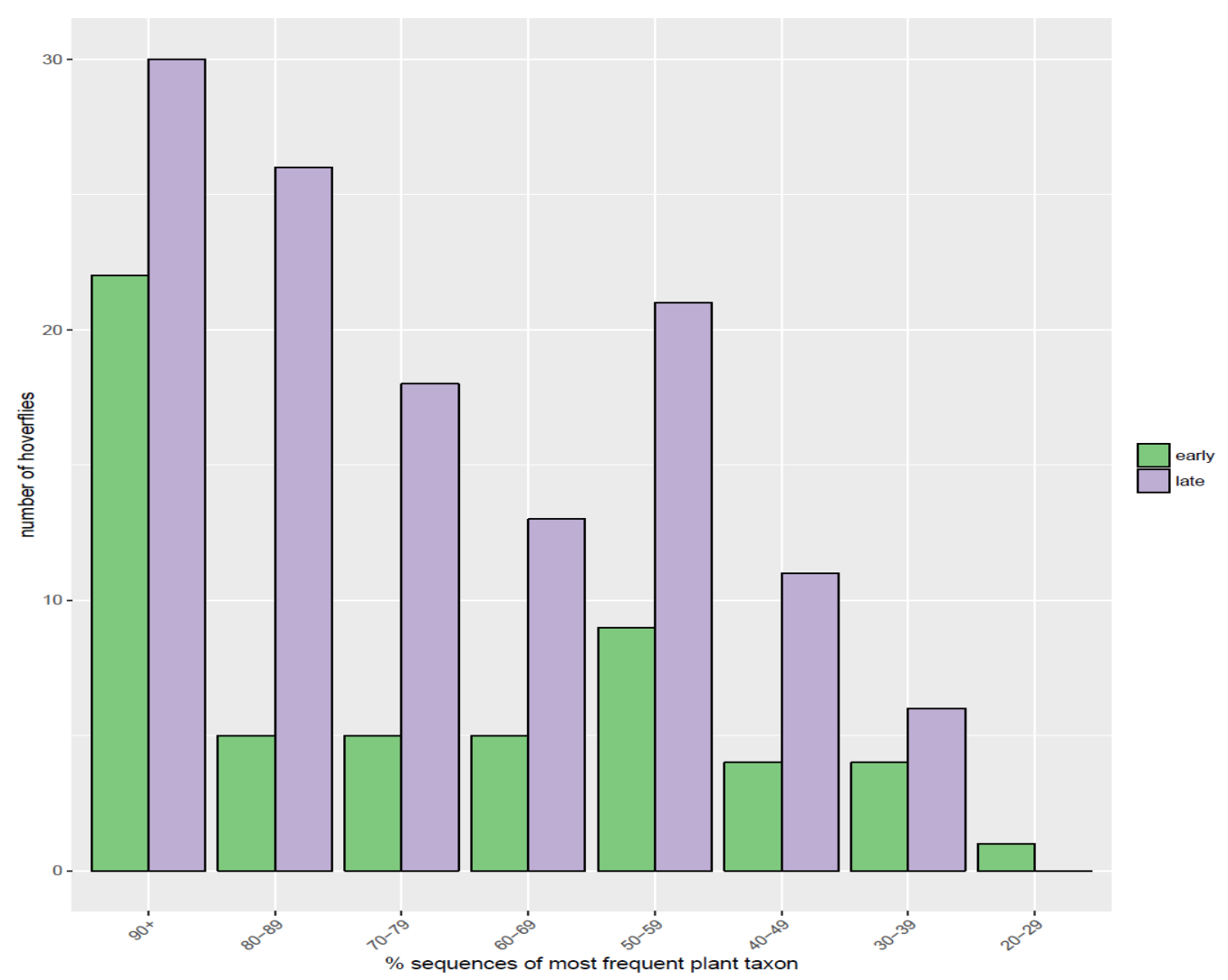

Figure 4. The percentage categories of the most frequent pollen DNA sequences from a single plant taxon recovered from individual Eristalis hoverflies at four grassland sites in early $(n=55)$ and late $(n=125)$ summer 2014

\section{Discussion}

Our results demonstrate that pollination transport networks amongst Eristalis hoverflies are generalised, but that this generalisation may be a consequence of short-term individual specialisation by individuals on particular plant species. The results have implications for the effectiveness of hoverflies as potential pollinators, and the role they play in the functioning of the grassland ecosystems used in this study.

All of the networks were generalised, with $H_{2}$ ' values below 0.3 . These values are comparable to those recorded in flower-visitor networks in bumblebees (Bombus) (Ballantyne, Baldock \& Willmer 2015) and moths (Lepidoptera) (Banza, Belo \& Evans 2015). The increasing generalisation (i.e. lower $\mathrm{H}_{2}$ 'value) during the summer may reflect the increasing amount and diversity of flower resources as the summer progresses. 
This is similar to the results of Baldock et al. (2015), who attributed generalisation in mixed pollinator networks in urban areas to the greater diversity of plants, including many non-native species. Our results are consistent with these and other studies that have described generalised pollen transport networks in temperate systems (Forup et al. 2008; Devoto, Bailey \& Memmott 2011; Marrero, Torretta \& Medan 2014).

Specialisation at the species level in our pollen transport networks, as described by $d^{\prime}$, was extremely low. This demonstrates that there is considerable functional redundancy in pollen transport amongst Eristalis species at our sites. Functional redundancy within ecological networks can increase ecosystem service stability (Russo et al. 2013) and robustness to extinctions (Kéfi et al. 2016). However, this functional redundancy may not extend to other habitats, as a species that is functionally redundant in one system may be pivotal in another (Fetzer et al. 2015).

Goulson and Wright (1998) demonstrated floral constancy by two species of hoverfly, Episyrphus balteatus and Syrphus ribesii. In our study, between $40 \%$ (early period) and $24 \%$ (late period) of hoverflies had at least $90 \%$ of their pollen sequences from a single plant taxon, with the majority having at least $60 \%$ of sequences from a single plant taxon. This suggests that individuals are showing some degree of specialisation. The number of hoverflies appearing to be visiting a single plant taxon declined during the summer, possibly as a result of increasing flower resources. Hoverflies can have colour preferences (Sutherland, Sullivan \& Poppy 1999) which may facilitate constancy, and evidence that hoverflies fly longer distances between feeding bouts than bees has been attributed to them not being central place foragers (Lysenkov 2009). The presence of predators and variation in feeding resources can also influence foraging behaviour in Eristalis tenax (Llandres, De Mas \& Rodriguez-Girones 2012). Our results show that flower constancy, as inferred by pollen loads, was a feature of foraging by Eristalis species in our study. However, further work is required to describe flower constancy in hoverflies and hoverfly foraging behaviour.

Whilst most plant-pollinator interactions studied appear to be generalised (Bosch et al. 2009; Ollerton et al. 2009), this appears to create a paradox: how do such networks ensure efficient pollination? Generalisation and specialisation can occur simultaneously, because whilst individual behaviour during a short-term foraging bout may be specialised, 
overall pollination by species and communities can be generalised (Ollerton 1996; Brosi 2016). Our results support this view, with relatively specialised pollen transport at the individual level, but generalised at the species and network level. Generalised hoverfly networks may therefore be an emergent property of a diverse set of individual short-term specialisms. This result is consistent with Tur et al. (2014), who investigated pollen transport from the whole network to individual insect level using microscopic palynological techniques.

The proportions of pollen sequence reads from hoverflies at each site are presented in figure 3. DNA metabarcoding does not provide a robustly quantitative measure of the amount of pollen. This is because of the possible variation in plastid copy number within the pollens of different species, along with biases that can be introduced during analysis, at DNA extraction, PCR and sequencing (Hawkins et al. 2015; ) 27 compared microscopy with 454-sequencing of pollen derived from honey and found that the most the most abundant plant taxa were similar between the two methods. Kraaijeveld et al. (2015) showed a good correlation between microscopy-based pollen counts and DNA sequence reads from airborne pollen, and proportions of sequence reads have been used as a semiquantitative measure of pollen abundance in honey bee pollen loads (de Vere et al., 2017). Conversely, Bell et al. (2017) noted that, although there may be some correlation between the number of sequence reads and amount of visually identified pollen within mixed samples, this correlation is only moderate, with some species found in different proportions between sequence read and pollen count data (Richardson et al., 2015). As a result, the data in figure 3 should be interpreted as only a semi-quantitative measure of the relative proportions of different plant taxa used by hoverflies. Because of these limitations, presence/absence data was used for the network analysis, as recommended by Bell et al. (2017).

Our study has revealed the extent to which hoverflies are transporting pollen in grassland systems. Morris (1998) lists 188 plant species visited by all hoverfly species in southern England. In contrast, this study found 65 distinct pollen taxa on Eristalis hoverflies at four sites, of which 33 were also recorded as visited by Eristalis species by Morris 
(1998). This indicates that hoverflies are visiting a wider range of plants than has been previously understood based on observations of flower visitation.

Our data indicate that Rubus fruticosus agg. and Succisa pratensis are critical plants for the hoverfly genus in our study. Rubus fruticosus agg. is a very rewarding nectarproducing plant for many insects (Baude et al. 2016). Hoverflies have also been recorded as key flower visitors for S. pratensis (Kwak 1993), a plant of conservation interest as the food plant of the endangered butterfly Euphydryas aurinia (marsh fritillary) (Wahlberg, Klemetti \& Hanski 2002). Our research suggests that this plant may also be a critical resource for hoverflies, who in turn may be playing an important role in S. pratensis reproduction. Both $R$. fruticosus agg. and S. pratensis may represent 'keystone species' (Memmott 1999) in these pollen transport networks, and may be facilitating the pollination of other plant species by acting as 'magnet species' (Johnson et al. 2003).

The pollen accumulated on the body of a hoverfly represents a record of its activity. The residence time of a pollen grain on the body of a hoverfly will determine how long a time period that record represents. Hoverflies engage in regular cleaning, by rubbing their legs across their body, wings and eyes (Holloway 1976). Gilbert (1985) showed that Eristalis species spend between 10 and $13 \%$ of their time resting, during which time they perform cleaning behaviour. However, this resting behaviour was mostly concentrated between 0800 and 1000, and again between 1400 and 1500. The remaining time was devoted to feeding or flight between flowers. Although even relatively brief cleaning bouts could potentially remove pollen, and different pollens will have varying adhesive quality, pollen loads could constitute a record of hoverfly behaviour over a significant proportion of a day's activity (Gyan \& Woodell 1987). Almost all insects carried at least two pollen taxa, suggesting that pollen is retained over a long enough period for the insect to have visited several plant taxa. Exploring the dynamics of pollen transport by hoverflies is an important subject to fully understand the role of these insects in pollination, and requires further research.

Bees are recognised to be the most effective insect pollinators in most systems, including grasslands (Willmer, Cunnold \& Ballantyne 2017). Nonetheless, non-bee pollinators can be effective pollinators of both wild and crop plants (Horsburgh, Semple \& Kevan 2011; Orford, Vaughan \& Memmott 2015; Rader et al. 2015). Our results suggest that 
individual Eristalis hoverflies show a degree of flower fidelity (Brosi 2016), a trait recognised as increasing pollination effectiveness (Morales \& Traveset 2008). However, transport of pollen by a flower-visiting species does not necessarily imply that the species is an effective pollinator (King, Ballantyne \& Willmer 2013; Ballantyne, Baldock \& Willmer 2015). Therefore, this study can only indicate the potential role that hoverflies may be playing in pollination services, and provides some insight into the foraging behaviour of hoverflies themselves. Further work is required, particularly to provide more data on hoverfly pollen loads early in the flight season. Similarly, this work focusses on one widespread genus of hoverflies. Other hoverfly species may have different foraging strategies (Haslett 1989; Branquart \& Hemptinn 2000), or may utilise other habitats, and consequently carry different pollen loads. Further work is also needed to reconcile pollen transport and actual pollination effectiveness, particularly in nonHymenopteran species.

\section{Conclusion}

There has been considerable debate about the structures of pollination networks, and the generalised nature of such networks, which appear contrary to the requirement of plants for efficient conspecific transport of pollen. Here, we show the value of DNA metabarcoding in the investigation of plant-pollinator interactions, which can reveal relationships more effectively than visit observations (Pornon et al. 2016). By allowing the systematic investigation of pollination networks from the level of individual insects through to whole communities, our results show how generalised networks can emerge from the short-term specialisation of individuals, thus reconciling generalised network structures with effective plant pollination. This study presents an example of DNA metabarcoding being used in the investigation of pollination by non-hymenopteran species, and adds to the knowledge base of ecosystem service provision. A future focus on integrating flower visitation, pollen transport, and pollination effectiveness will allow a more complete description of the structure and function of pollination networks.

\section{References}


Ambrosino, M.D., Luna, J.M., Jepson, P.C. \& Wratten, S.D. (2006) Relative Frequencies of Visits to Selected Insectary Plants by Predatory Hoverflies (Diptera: Syrphidae), Other Beneficial Insects, and Herbivores. Environmental Entomology, 35, 394 - 400. doi: 10.1603/0046-225X-35.2.394

Armbruster, W.S. (2016) The specialization continuum in pollination systems: diversity of concepts and implications for ecology, evolution and conservation. Functional Ecology, 31, doi: 10.1111/1365-2435.12783

Baldock, K.C.R., Goddard, M.A., Hicks, D.M., Kunin, W.E., Mitschunas, N., Osgathorpe, L.M., Potts, S.G., Robertson, K.M., Scott, A.V., Stone, G.N., Vaughan, I.P. \& Memmott, J. (2015) Where is the UK's pollinator biodiversity? The importance of urban areas for flower-visiting insects. Proceedings of the Royal Society of London B: Biological Sciences, 282. doi: 10.1098/rspb.2014.2849

Ballantyne, G., Baldock, K.C.R. \& Willmer, P.G. (2015) Constructing more informative plant-pollinator networks: visitation and pollen deposition networks in a heathland plant community. Proceedings of the Royal Society of London B: Biological Sciences, 282. doi: 10.1098/rspb.2014.2849

Banza, P., Belo, A.D.F. \& Evans, D.M. (2015) The structure and robustness of nocturnal Lepidopteran pollen-transfer networks in a Biodiversity Hotspot. Insect Conservation and Diversity, 8, 538-546. doi: 10.1111/icad.12134

Bascompte, J., Jordano, P., Melian, C.J. \& Olesen, J.M. (2003) The nested assembly of plant-animal mutualistic networks. Proceedings of the National Academy of Sciences of the United States of America, 100, 9383-9387. doi: 10.1073/pnas.1633576100

Bates, D., Mächler, M., Bolker, B. \& Walker, S. (2015) Fitting Linear Mixed-Effects Models Using lme4. Journal of Statistical Software; Vol 1, Issue 1 (2015). doi: 10.18637/jss.v067.i01

Baude, M., Kunin, W.E., Boatman, N.D., Conyers, S., Davies, N., Gillespie, M.A.K., Morton, R.D., Smart, S.M. \& Memmott, J. (2016) Historical nectar assessment reveals the fall and rise of floral resources in Britain. Nature, 530, 85-88. doi: 10.1038/nature16532 
Bell, K.L., de Vere, N., Keller, A., Richardson, R.T., Gous, A., Burgess, K.S. \& Brosi, B.J. (2016) Pollen DNA barcoding: current applications and future prospects. Genome, 59, 1-12. doi: 10.1139/gen-2015-0200

Bell, K.L., Fowler, J., Burgess, K.S., Dobbs, E.K., Gruenewald, D., Lawley, B., Morozumi, C. \& Brosi, B.J. (2017) Applying pollen DNA metabarcoding to the study of plant-pollinator interactions. Applications in Plant Sciences, 5. doi: 10.3732/apps. 1600124

Bell, K.L., Loeffler, V.M. \& Brosi, B.J. (2017) An rbcL reference library to aid in the identification of plant species mixtures by DNA metabarcoding. Applications in Plant Sciences, 5, doi: 10.3732/apps.1600110.

Blackstock, T., Howe, E. \& Stevens, J. (2010) Habitats of Wales: A Comprehensive Field Survey, 1979-1997 University of Wales.

Bluthgen, N., Menzel, F. \& Bluthgen, N. (2006) Measuring specialization in species interaction networks. BMC Ecology, 6, 9 doi: 10.1186/1472-6785-6-9

Bosch, J., Martín González, A.M., Rodrigo, A. \& Navarro, D. (2009) Plant-pollinator networks: adding the pollinator's perspective. Ecology Letters, 12, 409-419. doi: 10.1111/j.1461-0248.2009.01296.x

Branquart, E. \& Hemptinn, J. (2000) Selectivity in the exploitation of floral resources by hoverflies (Diptera: Syrphinae). Ecography, 23, 732 - 742.

Brosi, B.J. (2016) Pollinator specialization: from the individual to the community. New Phytologist, 4, 1190 - 1194. doi: 10.1111/nph.13951

Brosi, B.J. \& Briggs, H.M. (2013) Single pollinator species losses reduce floral fidelity and plant reproductive function. Proceedings of the National Academy of Sciences, 110, 13044-13048. doi: 10.1073/pnas.1307438110

Bruni, I., Galimberti, A., Caridi, L., Scaccabarozzi, D., De Mattia, F., Casiraghi, M. \& Labra, M. (2015) A DNA barcoding approach to identify plant species in multiflower honey. Food Chemistry, 170, 308 - 315. doi:

10.1016/j.foodchem.2014.08.060

CBOL Plant Working Group, Hollingsworth, P.M., Forrest, L.L., Spouge, J.L., Hajibabaei, M., Ratnasingham, S., van der Bank, M., Chase, M.W., Cowan, R.S., Erickson, D.L., Fazekas, A.J., Graham, S.W., James, K.E., Kim, K.-J., Kress, W.J., Schneider, H., van AlphenStahl, J., Barrett, S.C.H., van den Berg, C., Bogarin, D., Burgess, K.S., Cameron, K.M., Carine, M., Chacón, J., Clark, A., 
Clarkson, J.J., Conrad, F., Devey, D.S., Ford, C.S., Hedderson, T.A.J., Hollingsworth, M.L., Husband, B.C., Kelly, L.J., Kesanakurti, P.R., Kim, J.S., Kim, Y.-D., Lahaye, R., Lee, H.-L., Long, D.G., Madriñán, S., Maurin, O., Meusnier, I., Newmaster, S.G., Park, C.-W., Percy, D.M., Petersen, G., Richardson, J.E., Salazar, G.A., Savolainen, V., Seberg, O., Wilkinson, M.J., Yi, D.-K. \& Little, D.P. (2009) A DNA barcode for land plants. Proceedings of the National Academy of Sciences, 106, 12794-12797. doi: 10.1073/pnas.0905845106 Clare, E.L., Schiestl, F.P., Leitch, A.R. \& Chittka, L. (2013) The promise of genomics in the study of plant-pollinator interactions. Genome Biology, 14. doi:10.1186/gb2013-14-6-207

Creer, S., Deiner, K., Frey, S., Porazinska, D., Taberlet, P., Thomas, W.K., Potter, C. \& Bik, H.M. (2016) The ecologist's field guide to sequence-based identification of biodiversity. Methods in Ecology and Evolution, 9, doi: 10.1111/2041210X.12574.

de Vere, N., Jones, L., Gilmore, T., Moscrop, J., Lowe, A., Smith, D., Hegarty, M., Creer, S. \& Ford, C. (2017) Using DNA metabarcoding to investigate honey bee foraging reveals limited flower use despite high floral availability. Scientific Reports, 7. doi: $10.1038 \% 2 F s r e p 42838$

de Vere, N., Rich, T.C.G., Ford, C.R., Trinder, S.A., Long, C., Moore, C.W., Satterthwaite, D., Davies, H., Allainguillaume, J., Ronca, S., Tatarinova, T., Garbett, H., Walker, K. \& Wilkinson, M.J. (2012) DNA Barcoding the Native Flowering Plants and Conifers of Wales. Plos One, 7. doi: 10.1371/journal.pone.0037945

Devoto, M., Bailey, S. \& Memmott, J. (2011) The 'night shift': Nocturnal pollen-transport networks in a boreal pine forest. Ecological Entomology, 36, 25-35. doi: $10.1111 / \mathrm{j} .1365-2311.2010 .01247 . \mathrm{x}$

Dicks, L.V., Abrahams, A., Atkinson, J., Biesmeijer, J., Bourn, N., Brown, C., Brown, M.J.F., Carvell, C., Connolly, C., Cresswell, J.E., Croft, P., Darvill, B., De Zylva, P., Effingham, P., Fountain, M., Goggin, A., Harding, D., Harding, A., Hartfield, C., Heard, M.E., Heathcote, R., Heaver, D., Holland, J., Howe, M., Hughes, B., Huxley, Y., Kunin, W.E., Little, J., Mason, C., Memmott, J., Osborne, J., Pankhurst, T., Paxton, R.J., Pocock, M.J.O., Potts, S.G., Power, E.F., Raine, N.E., Ranelagh, E., Roberts, S., Saunders, R., Smith, K., Smith, R.M., Sutton, P., Tilley, 
L.A.N., Tinsley, A., Tonhasca, A., Vanbergen, A.J., Webster, S., Wilson, A. \& Sutherland, W.J. (2013) Identifying key knowledge needs for evidence-based conservation of wild insect pollinators: a collaborative cross-sectoral exercise Insect Conservation and Diversity, 6, 435 - 446. doi: 10.1111/j.17524598.2012.00221.x

Dicks, L.V., Corbet, S.A. \& Pywell, R.F. (2002) Compartmentalization in plant-insect flower visitor webs. Journal of Animal Ecology, 71, 32-43. doi: 10.1046/j.00218790.2001.00572.x

Dormann, C.F., Gruber, B. \& Frund, J. (2008) Introducing the bipartite package: analysing ecological networks. $R$ News, 8,8 - 11.

Fetzer, I., Johst, K., Schäwe, R., Banitz, T., Harms, H. \& Chatzinotas, A. (2015) The extent of functional redundancy changes as species' roles shift in different environments. Proceedings of the National Academy of Sciences, 112, 1488814893. doi: 10.1073/pnas. 1505587112

Forup, M.L., Henson, K.S.E., Craze, P.G. \& Memmott, J. (2008) The restoration of ecological interactions: Plant-pollinator networks on ancient and restored heathlands. Journal of Applied Ecology, 45, 742-752. doi: 10.1111/j.13652664.2007.01390.x

Galimberti, A., De Mattia, F., Bruni, I., Scaccabarozzi, D., Sandionigi, A., Barbuto, M., Casiraghi, M. \& Labr, M. (2014) A DNA Barcoding Approach to Characterize Pollen Collected by Honeybees. PLoS ONE, 9(10). doi:

10.1371/journal.pone.0109363

Garibaldi, L., Steffan-Dewenter, I., Winfree, R., Aizen, M., Bommarco, R., Cunningham, S., Kremen, C., Carvalheiro, L., Harder, L., Afik, O., Bartomeus, I., Benjamin, F., Boreux, V., Cariveau, D., Chacoff, N., Dudenhoffer, J., Freitas, B., Ghazoul, J., Greenleaf, S., Hipolito, J., Holzschuh, A., Howlett, B., Isaacs, R., Javorek, S., Kennedy, C., Krewenka, K., Krishnan, S., Mandelik, Y., Mayfield, M., Motzke, I., Munyuli, T., Nault, B., Otieno, M., Petersen, J., Pisanty, G., Potts, S., Rader, R., Ricketts, T., Rundlof, M., Seymour, C., Schuepp, C., Szentgyorgyi, H., Taki, H., Tscharntke, T., Vergara, C., Viana, B., Wanger, T., Westphal, C., Williams, N. \& Klein, A. (2013) Wild Pollinators Enhance Fruit Set of Crops Regardless of Honey Bee Abundance. Science, 339, 1608-1611. doi: 10.1126/science.1230200 
Gilbert, F. (1985) Diurnal activity patterns in hoverflies (Diptera: Syrphidae). Ecological Entomology, 10, 385 - 392.

Gill, R.J., Baldock, K.C.R., Brown, M.J.F., Cresswell, J.E., Dicks, L.V., Fountain, M.T., Garratt, M.P.D., Gough, L.A., Heard, M.S., Holland, J.M., Ollerton, J., Stone, G.N., Tang, C.Q., Vanbergen, A.J., Vogler, A.P., Woodward, G., Arce, A.N., Boatman, N.D., Brand-Hardy, R., Breeze, T.D., Green, M., Hartfield, C.M., O’Connor, R.S., Osborne, J.L., Phillips, J., Sutton, P.B. \& Potts, S.G. (2016) Protecting an Ecosystem Service: Approaches to Understanding and Mitigating Threats to Wild Insect Pollinators. Advances in Ecological Research, 54, 135 206. doi: 10.1016/bs.aecr.2015.10.007

Gilman, R.T., Fabina, N.S., Abbott, K.C. \& Rafferty, N.E. (2012) Evolution of plantpollinator mutualisms in response to climate change. Evolutionary Applications, 5, 2-16. doi: 10.1111/j.1752-4571.2011.00202.x

Golding, Y. \& Edmunds, M. (2003) A novel method to investigate the pollen diets of hoverflies. Journal of Biological Education, 37, 182-185.

Goulson, D. \& Wright, N.P. (1998) Flower constancy in the hoverflies Episyrphus balteatus (Degeer) and Syrphus ribesii (L.) (Syrphidae). Behavioral Ecology, 9, 213 - 219. doi: 10.1093/beheco/9.3.213

Gyan, K.Y. \& Woodell, S.R.J. (1987) Analysis of Insect Pollen Loads and Pollination Efficiency of Some Common Insect Visitors of Four Species of Woody Rosaceae. Functional Ecology, 1, 269-274. doi: 10.2307/2389430

Haslett, J.R. (1989) Interpreting patterns of resource utilization: randomness and selectivity in pollen feeding by adult hoverflies. Oecologia, 78, 433 - 442. doi: 10.1007/BF00378732

Hawkins, J., de Vere, N., Griffith, A., Ford, C.R., Allainguillaume, J., Hegarty, M.J., Baillie, L. \& Adams-Groom, B. (2015) Using DNA Metabarcoding to Identify the Floral Composition of Honey: A New Tool for Investigating Honey Bee Foraging Preferences. PLoS ONE, 10, doi: 10.1371/journal.pone.0134735

Holloway, B.A. (1976) Pollen-feeding in hover-flies (Diptera: Syrphidae). New Zealand Journal of Zoology, 3, 339-350. doi: 10.1080/03014223.1976.9517924

Horsburgh, M., Semple, J.C. \& Kevan, P.G. (2011) Relative Pollinator Effectiveness of Insect Floral Visitors to Two Sympatric Species of Wild Aster: Symphyotrichum 
lanceolatum (Willd.) Nesom and S. lateriflorum (L.) Löve \& Löve (Asteraceae: Astereae). Rhodora, 113, 64-86. doi: 10.3119/08-09.1

Illumina (2013) 16S Metagenomic Sequencing Library Preparation. pp.

https://support.illumina.com/content/dam/illumina-

support/documents/documentation/chemistry_documentation/16s/16smetagenomic-library-prep-guide-15044223-b.pdf.

IPBES (2016) Summary for policymakers of the assessment report of the Intergovernmental Science-Policy Platform on Biodiversity and Ecosystem Services on pollinators, pollination and food production. (eds S.G. Potts, V.L. Imperatriz-Fonseca, H.T. Ngo, J.C. Biesmeijer, T.D. Breeze, L.V. Dicks, L.A. Garibaldi, R. Hill, J. Settele, A.J. Vanbergen, M.A. Aizen, S.A. Cunningham, C. Eardley, B.M. Freitas, N. Gallai, P.G. Kevan, A. Kovács-Hostyánszki, P.K. Kwapong, J. Li, X. Li, D.J. Martins, G. Nates-Parra, J.S. Pettis, R. Rader \& B.F. Viana), pp. 36 pages. Secretariat of the Intergovernmental Science-Policy Platform on Biodiversity and Ecosystem Services, Bonn, Germany.

Johnson, S.D., Hollens, H. \& Kuhlmann, M. (2012) Competition versus facilitation: conspecific effects on pollinator visitation and seed set in the iris Lapeirousia oreogena. Oikos, 121, 545-550.

Johnson, S.D., Peter, C.I., Nilsson, L.A. \& Ågren, J. (2003) Pollination success in a deceptive orchid is enhanced by co-occurring rewarding magnet plants. Ecology, 84, 2919-2927. doi: 10.1111/j.1600-0706.2011.19516.x

Jordano, P. (2016) Natural history matters: how biological constraints shape diversified interactions in pollination networks. Journal of Animal Ecology, 85, 1423-1426. doi: 10.1111/1365-2656.12584

Kaiser-Bunbury, C.N., Muff, S., Memmott, J., Müller, C.B. \& Caflisch, A. (2010) The robustness of pollination networks to the loss of species and interactions: A quantitative approach incorporating pollinator behaviour. Ecology Letters, 13, 442-452. doi: 10.1111/j.1461-0248.2009.01437.x

King, C., Ballantyne, G. \& Willmer, P. (2013) Why flower visitation is a poor proxy for pollination: measuring single-visit pollen deposition, with implications for pollination networks and conservation. Methods in Ecology and Evolution, 4, 811818. doi: 10.1111/2041-210X.12074 
Kraaijeveld, K., de Weger, L.A., Ventayol García, M., Buermans, H., Frank, J., Hiemstra, P.S. \& den Dunnen, J.T. (2015) Efficient and sensitive identification and quantification of airborne pollen using next-generation DNA sequencing. Molecular Ecology Resources, 15, 8-16.

Kwak, M.M. (1993) The relative importance of syrphidae and bumblebees as pollinators of three plant species. Proceedings of Experimental and Applied Entomology, 4, $137-143$.

Kéfi, S., Miele, V., Wieters, E.A., Navarrete, S.A. \& Berlow, E.L. (2016) How Structured Is the Entangled Bank? The Surprisingly Simple Organization of Multiplex Ecological Networks Leads to Increased Persistence and Resilience. PLoS Biol, 14, doi: 10.1371/journal.pbio.1002527

Llandres, A.L., De Mas, E. \& Rodriguez-Girones, M.A. (2012) Response of pollinators to the tradeoff between resource acquisition and predator avoidance. Oikos, 121, 687-696. doi: 10.1111/j.1600-0706.2011.19910.x

Lysenkov, S.N. (2009) On the estimation of the influence of the character of insect pollinators movements on the pollen transfer dynamics. Entomological Review, 89, 143-149. doi: 10.1134/S0013873809020031

Marrero, H.J., Torretta, J.P. \& Medan, D. (2014) Effect of land use intensification on specialization in plant-floral visitor interaction networks in the Pampas of Argentina. Agriculture, Ecosystems and Environment, 188, 63-71. doi: 10.1016/j.agee.2014.02.017

Memmott, J. (1999) The structure of a plant-pollinator food web. Ecology Letters, 2, 276280. doi: 10.1046/j.1461-0248.1999.00087.x

Memmott, J., Craze, P.G., Waser, N.M. \& Price, M.V. (2007) Global warming and the disruption of plant-pollinator interactions. Ecology Letters, 10, 710-717. doi: 10.1111/j.1461-0248.2007.01061.x

Memmott, J., Waser, N.M. \& Price, M.V. (2004) Tolerance of pollinator networks to species extinctions. Proceedings of the Royal Society B, 271, 2605 - 2611. doi: https://dx.doi.org/10.1098\%2Frspb.2004.2909

Morales, C.L. \& Traveset, A. (2008) Interspecific Pollen Transfer: Magnitude, Prevalence and Consequences for Plant Fitness. Critical Reviews in Plant Sciences, 27, 221238. doi: $10.1080 / 07352680802205631$

Morris, R.K.A. (1998) Hoverflies of Surrey. Surrey Wildlife Trust, Woking. 
Nicolson, S.W. \& Wright, G.A. (2017) Plant-pollinator interactions and threats to pollination: perspectives from the flower to the landscape. Functional Ecology, 31, 22-25. doi: 10.1111/1365-2435.12810

Ollerton, J. (1996) Reconciling Ecological Processes with Phylogenetic Patterns: The Apparent Paradox of Plant--Pollinator Systems. Journal of Ecology, 84, 767-769. doi: $10.2307 / 2261338$

Ollerton, J., Alarcón, R., Waser, N.M., Price, M.V., Watts, S., Cranmer, L., Hingston, A., Peter, C.I. \& Rotenberry, J. (2009) A global test of the pollination syndrome hypothesis. Annals of Botany, 103, 1471-1480. doi: 10.1093/aob/mcp031

Orford, K.A., Vaughan, I.P. \& Memmott, J. (2015) The forgotten flies: the importance of non-syrphid Diptera as pollinators. Proceedings of the Royal Society B, 282. doi: 10.1098/rspb.2014.2934

Petanidou, T., Kallimanis, A.S., Tzanopoulos, J., Sgardelis, S.P. \& Pantis, J.D. (2008) Long-term observation of a pollination network: Fluctuation in species and interactions, relative invariance of network structure and implications for estimates of specialization. Ecology Letters, 11, 564-575. doi: 10.1111/j.14610248.2008.01170.x

Pornon, A., Escaravage, N., Burrus, M., Holota, H., Khimoun, A., Mariette, J., Pellizzari, C., Iribar, A., Etienne, R., Taberlet, P., Vidal, M., Winterton, P., Zinger, L. \& Andalo, C. (2016) Using metabarcoding to reveal and quantify plant-pollinator interactions. Scientific Reports, 6, doi: 10.1038/srep27282

Potts, S.G., Imperatriz-Fonseca, V., Ngo, H.T., Aizen, M.A., Biesmeijer, J.C., Breeze, T.D., Dicks, L.V., Garibaldi, L.A., Hill, R., Settele, J. \& Vanbergen, A.J. (2016) Safeguarding pollinators and their values to human well-being. Nature. 540, 220 229 doi:10.1038/nature20588

R Core Team (2014) R: a language and environment for statistical computing., pp. http://www.R-project.org R Foundation for Statistical Computing, Vienna, Austria.

Rader, R., Bartomeus, I., Garibaldi, L.A., Garratt, M.P.D., Howlett, B.G., Winfree, R., Cunningham, S.A., Mayfield, M.M., Arthur, A.D., Andersson, G.K.S., Bommarco, R., Brittain, C., Carvalheiro, L.G., Chacoff, N.P., Entling, M.H., Foully, B., Freitas, B.M., Gemmill-Herren, B., Ghazoul, J., Griffin, S.R., Gross, C.L., Herbertsson, L., Herzog, F., Hipólito, J., Jaggar, S., Jauker, F., Klein, A.-M., 
Kleijn, D., Krishnan, S., Lemos, C.Q., Lindström, S.A.M., Mandelik, Y., Monteiro, V.M., Nelson, W., Nilsson, L., Pattemore, D.E., de O. Pereira, N., Pisanty, G., Potts, S.G., Reemer, M., Rundlöf, M., Sheffield, C.S., Scheper, J., Schüepp, C., Smith, H.G., Stanley, D.A., Stout, J.C., Szentgyörgyi, H., Taki, H., Vergara, C.H., Viana, B.F. \& Woyciechowski, M. (2015) Non-bee insects are important contributors to global crop pollination. Proceedings of the National Academy of Sciences, 113, 146 - 151. doi: 10.1073/pnas.1517092112

Richardson, R. T., Lin, C.-H., Quijia, J. O., Riusech, N. S., Goodell, K., \& Johnson, R. M. (2015a). Rank-Based Characterization of Pollen Assemblages Collected by Honey Bees Using a Multi-Locus Metabarcoding Approach. Applications in Plant Sciences, 3(11), 1500043. doi:10.3732/apps.1500043

Rodwell, J., Pigott, C.D., Ratclliffe, D.A., Malloch, A.J.C., Proctor, M.C.F., Shimwell, D.W., Huntley, J.P., Radford, E., Wigginton, M.J. \& Wilkins, P. (1991) British Plant Communities Volume 2. Mires and heaths. Cambridge University Press, Cambridge.

Russo, L., Debarros, N., Yang, S., Shea, K. \& Mortensen, D. (2013) Supporting crop pollinators with floral resources: Network-based phenological matching. Ecology and Evolution, 3, 3125-3140. doi: 10.1002/ece3.703

Stanley, D.A., Gunning, D. \& Stout, J.C. (2013) Pollinators and pollination of oilseed rape crops (Brassica napus L.) in Ireland: ecological and economic incentives for pollinator conservation. Journal of Insect Conservation, 17, 1181-1189. doi: $10.1007 / \mathrm{s} 10841-013-9599-\mathrm{z}$

Stokl, J., Brodmann, J., Dafni, A., Ayasse, M. \& Hansson, B.S. (2011) Smells like aphids: orchid flowers mimic aphid alarm pheromones to attract hoverflies for pollination. Proceedings of the Royal Society B-Biological Sciences, 278, 1216 1222. doi: $10.1098 /$ rspb.2010.1770

Sutherland, J.P., Sullivan, M.S. \& Poppy, G.M. (1999) The influence of floral character on the foraging behaviour of the hoverfly, Episyrphus balteatus. Entomologia Experimentalis Et Applicata, 93, 157-164. doi: 10.1046/j.15707458.1999.00574.x 
Tucker, E.M. \& Rehan, S.M. (2016) Wild bee pollination networks in northern New England. Journal of Insect Conservation, 20, 325-337. doi: 10.1007/s10841-0169870-1

Tur, C., Vigalondo, B., Trøjelsgaard, K., Olesen, J.M. \& Traveset, A. (2014)

Downscaling pollen-transport networks to the level of individuals. Journal of Animal Ecology, 83, 306-317. doi: 10.1111/1365-2656.12130

Vanbergen, A.J., Woodcock, B.A., Gray, A., Grant, F., Telford, A., Lambdon, P., Chapman, D.S., Pywell, R.F., Heard, M.S. \& Cavers, S. (2014) Grazing alters insect visitation networks and plant mating systems. Functional Ecology, 28, 178 189. doi: 10.1111/1365-2435.12191

Wahlberg, N., Klemetti, T. \& Hanski, I. (2002) Dynamic populations in a dynamic landscape: the metapopulation structure of the marsh fritillary butterfly. Ecography, 25, 224-232. doi: 10.1034/j.1600-0587.2002.250210.x

Waser, N.M., Chittka, L., Price, M.V., Williams, N.M. \& Ollerton, J. (1996) Generalization in Pollination Systems, and Why it Matters. Ecology, 77, 10431060.

Waser, N.W. (1986) Flower Constancy: definition, cause and measurement. American Naturalist, 127, 593 - 603. doi: 10.2307/2265575

Willmer, P.G., Cunnold, H. \& Ballantyne, G. (2017) Insights from measuring pollen deposition: quantifying the pre-eminence of bees as flower visitors and effective pollinators. Arthropod-Plant Interactions, 11, 411-425. doi: 10.1007/s11829-0179528-2

Wilson, E.E., Sidhu, C.S., LeVan, K.E. \& Holway, D.A. (2010) Pollen foraging behaviour of solitary Hawaiian bees revealed through molecular pollen analysis. Molecular Ecology, 19, 4823-4829. doi: 10.1111/j.1365-294X.2010.04849.x Woodcock, T.S., Larson, B.M.H., Kevan, P.G., Inouye, D.W. \& Lunau, K. (2014) Flies and Flowers II: Floral Attractants and Rewards. Journal of Pollination Ecology 12(8), 63-94 


\section{Chapter 6}

\section{Floral resource partitioning by individuals within generalised hoverfly pollination networks revealed by DNA metabarcoding}

Andrew Lucas, Owen Bodger, Berry J Brosi, Col R. Ford, Dan W. Forman, Carolyn Greig, Matthew Hegarty, Laura Jones, Penelope J. Neyland, Natasha de Vere

(NB: following peer review, this chapter was published in an amended form as Lucas et al. (2018) Floral resource partitioning by individuals within generalised hoverfly pollination networks revealed by DNA metabarcoding. Scientific Reports volume 8, Article number: 5133 (2018) doi:10.1038/s41598-018-23103-0)

Andrew Lucas conceived the study, undertook fieldwork, DNA sample preparation, statistical analysis, and led the writing of the manuscript. Owen Bodger and Berry Brosi performed statistical analysis and drafted the manuscript. Col Ford undertook data analysis and figure design. Dan Forman and Penny Neyland helped to conceive and plan the study, and draft the manuscript. Carolyn Greig designed the pollen removal protocol, and drafted the manuscript. Matt Hegarty and Laura Jones assisted with development of NGS metabarcoding protocols and creation of the sequencing libraries. Matt Hegarty performed the NGS runs and assisted with data analysis. Natasha de Vere conceived and designed the experiments, acquired and analysed the data, and drafted the manuscript. 


\section{Summary}

Pollination is a key ecosystem service for agriculture and wider ecosystem function. However, most pollination studies focus on Hymenoptera, with hoverflies (Syrphidae) frequently treated as a single functional group. We tested this assumption by investigating pollen carried by eleven species of hoverfly in five genera, Cheilosia, Eristalis, Rhingia, Sericomyia and Volucella, using DNA metabarcoding. Hoverflies carried pollen from 59 plant taxa, suggesting they visit a wider number of plant species than previously appreciated. Most pollen recorded came from plant taxa frequently found at our study sites, predominantly Apiaceae, Cardueae, Calluna vulgaris, Rubus fruticosus agg., and Succisa pratensis, with hoverflies transporting pollen from $\mathbf{4 0 \%}$ of entomophilous plant species present. Overall pollen transport network structures were generalised, similar to other pollination networks elsewhere. All hoverfly species were also generalised with few exclusive plant/hoverfly interactions. However, using the Jaccard Index, we found significant differences in the relative composition of pollen loads between hoverfly genera, except for Volucella, demonstrating some degree of functional complementarity. Eristalis and Sericomyia species had significant differences in relative pollen load composition compared to congeners. Our results indicate that treating hoverflies as a single group may underestimate the range of pollination function within this ecologically and morphologically diverse guild. 


\section{Introduction}

Pollination is a key ecosystem service which sustains significant food production (Klein et al. 2007; Vanbergen et al. 2013). In addition, by enabling wild plant reproduction (Ollerton, Winfree \& Tarrant 2011), pollination maintains plant diversity and therefore promotes wider ecosystem functioning on which other services, such as production of biomass and the cycling of nutrients, depend (Isbell et al. 2011). Wild insect species are effective pollinators that, in many situations, exceed the importance of domesticated honey bees Apis mellifera (Rader et al. 2009; Garibaldi et al. 2013). Understanding interactions between wild pollinators and plants is critical, because pollination network structure has implications for the stability of pollination as an ecosystem service in the face of environmental change (Valdovinos et al. 2013; Vanbergen et al. 2017).

Pollination networks previously studied have had a generalised structure, with plants having numerous potential pollinators, and pollinators in turn visiting many plant species (Memmott 1999; Bascompte et al. 2003). The plant species in these networks are predominantly ecological and functional generalists, with flowers that are accessible to a range of potential pollinators (Armbruster 2016; Fort, Vázquez \& Lan 2016). Such generalised networks can be more robust to species extinctions, because plants are able to exchange pollinator species if pollinator populations fluctuate (CaraDonna et al. 2017).

There is an increasing appreciation that flies (Diptera) have an important role in pollination, particularly at higher latitudes (Orford, Vaughan \& Memmott 2015; Grass et al. 2016). Amongst the Diptera, hoverflies (Syrphidae) are key pollinators of both crops (Rader et al. 2015) and wild plant species (Branquart \& Hemptinn 2000). Most studies of hoverflies have focussed on a small number of well-known species, particularly Eristalis tenax and Episyrphus balteatus (Sutherland, Sullivan \& Poppy 1999; van Rijn \& Wäckers 2016). However, hoverflies are a diverse family containing approximately 6000 species worldwide (Wardhaugh 2015), with 282 species recorded from Britain (Chandler 2017). The flower preferences of adult hoverflies, and their role in pollination, are little known for most species (Mayer et al. 2011). With the observed decline in many hymenopteran pollinators, there is a need for a greater understanding of the role of flies in plant pollinator interactions (Dicks et al. 2013). 
A range of techniques have been used to study plant - pollinator interactions. There is a long history of counting plant visitors in natural communities (Parmenter 1958; Larson, Kevan \& Inouye 2001), whilst other methods include devising experimental situations with a limited choice of foraging options (Ambrosino et al. 2006), or retrieving and identifying pollen from insect guts using traditional palynological methods (Haslett 1989). However, the existing techniques have strong limitations. Hoverflies can be difficult to follow in the wild, with some species known to forage in woodland canopies (Birtele \& Hardersen 2012). The visual identification of pollen can also be challenging, even for experienced observers, given the similarity in pollen morphology within some plant families (Hawkins et al. 2015).

DNA metabarcoding - the sequencing and identification of mixed DNA samples using next-generation sequencing - has opened new opportunities for study in a range of ecological contexts (Creer et al. 2016). This technique has been used to investigate the composition of invertebrate communities (Yu et al. 2012) and to examine the structure of food webs (Kaartinen et al. 2010; Kartzinel et al. 2015), and also has shown considerable potential in the study of pollen transport (Richardson et al. 2015; Bell et al. 2016; Bell et al. 2017). DNA metabarcoding has been shown to be a reliable method of identifying pollen, either carried as loads by insects (Pornon et al. 2016) or derived from honey (Hawkins et al. 2015). Molecular techniques to identify pollen have been used to investigate wild bee pollination of native and non-native plant species (Wilson et al. 2010), and pollen collection by domestic honey bees (de Vere et al. 2017).

Here, we use DNA metabarcoding to investigate pollen transport in hoverfly communities in fen-meadows, a species-rich grassland community found on peaty mineral soils in grasslands of conservation importance in lowland Wales, United Kingdom (Rodwell et al. 1991), and which are an endangered habitat of European importance (McLeod et al.). Such agriculturally unimproved grasslands remain a significant part of the biodiversity in south-west Wales (Stevens, Smith \& Blackstock 2010), and have the potential to provide ecosystem services, such as pollination by hoverflies, to the wider countryside (Power, Jackson \& Stout 2016). We retrieved pollen carried by eleven hoverfly species in five genera - Cheilosia, Eristalis, Rhingia, Sericomyia and Volucella - and sequenced the standard plant DNA barcode region $r b c L$. We then matched and identified the sequences using a standard pre-existing library of plant barcode sequences (de Vere et al. 2012), 
allowing us to characterise the overall composition of pollen loads for each hoverfly species. We used this information to construct pollen transport networks for the three grasslands in our study, and calculated a series of established network metrics to describe structure at the level of the overall network $\left(\mathrm{H}_{2}{ }^{\prime}\right)$ and species $\left(d^{\prime}\right)$ (Bluthgen, Menzel \& Bluthgen 2006).

We predicted that the networks would have a generalised structure (i.e. low values of $\mathrm{H}_{2}$ ' and $d^{\prime}$ ) consistent with other networks studied elsewhere (Baldock et al. 2015;

Ballantyne, Baldock \& Willmer 2015). Using the Jaccard Index, we investigated the similarity in pollen load composition between the five genera, and between species in two genera, Eristalis and Sericomyia, where more than one species was available. Given the notable morphological and behavioural differences, we predicted significant differences in the pollen loads between these distinctive hoverfly genera. For the six Eristalis species we predicted that, given that all species are common in the study area and are relatively morphologically uniform, there would be no differences in the composition of pollen loads between species. However, the two Sericomyia species are quite distinctive in their morphology and ecology. Sericomyia silentis is a relatively common, wasp-mimic species, whilst $S$. superbiens is a bumble bee mimic that, in Britain, is mainly restricted to wet pastures in the west and north. We therefore predicted that, in contrast to Eristalis species, there would be significant differences in the composition of pollen loads between the two species of Sericomyia.

\section{Methods}

\section{Site Descriptions}

The study took place during 2014 at three grassland sites of high conservation importance in west Wales, United Kingdom. We collected hoverflies at these locations (referred to here as 'CAD', 'LLC', and 'TRE'), where the National Vegetation Classification community M24 Molinia caerulea - Cirsium dissectum fen-meadow (Cirsio Molinietum caerulae) (Rodwell et al. 1991) was present (for full site information, see Appendix 1).

All sites were typical of this community. Molinia caerulea, Potentilla erecta, Succisa pratensis, and Lotus pedunculatus were all common in the sward, with Cirsium dissectum 
occurring more locally. Other frequent forb species included Calluna vulgaris, Ranunculus species, other Cirsium species, Serratula tinctoria and Carum verticillatum. Sward height was between approximately $20 \mathrm{~cm}$ and $60 \mathrm{~cm}$. Each site consisted of a single field, surrounded by hedgerows consisting mainly of Crategus monogyna, Prunus spinosa, and Corylus avellana, with frequent Rubus fruticosus agg. also present. We compiled a plant species list from existing grassland quadrat data for each site (Bevan et al. 2006), together with records of hedgerow species for each site collected in October 2015. From this species list, a sub-list of entomophilous plants was created by excluding grasses (Poaceae), sedges (Cyperaceae), and rushes (Juncaceae). Subsequently, a list of all plant pollen taxa recorded from pollen loads of all hoverfly species was compared to the entomophilous plant sub-list. For this purpose, all plant taxa recorded at a higher level than species were assumed to have come from a single plant species, irrespective of how many plant species were present. A species list for each site is included as Appendix 2.

\section{Field Collection of Hoverflies}

We collected insects between July 10 and August 27 2014. To ensure the insects captured were representative of the site as a whole, a series of transects $20 \mathrm{~m}$ apart were walked across each site, during which hoverflies were collected, ensuring that the entire site was searched. Each site was searched for three hours in total, with transects repeated as necessary. We placed the insects individually in $1.5 \mathrm{ml}$ tubes immediately after capture, which were subsequently stored at $-20^{\circ} \mathrm{C}$ prior to pollen removal. Following pollen removal, we identified the hoverflies morphologically to species (Stubbs \& Falk 2002).

\section{Pollen removal}

We initially washed the insects in the tube in which the insect had been placed in the field. The fly was immersed in $1 \mathrm{ml}$ of a $1 \%$ sodium dodecyl sulphate (SDS) and $2 \%$ poly-vinyl pyrrolidinone (PVP) solution in water. The tube was shaken vigorously by hand for 1 minute, and then centrifuged briefly to ensure that the insect was fully immersed in the liquid. It was then allowed to stand at room temperature for 5 minutes. The tube was then shaken vigorously by hand for 20 seconds. The fly was removed using 
forceps to a clean $1.5 \mathrm{ml}$ microfuge tube and frozen at $-20^{\circ} \mathrm{C}$ for subsequent species identification. The tube containing the detergent and pollen was centrifuged at 13000 rpm for 5 minutes.

\section{DNA extraction}

We used the DNeasy plant mini kit (Qiagen) for DNA extraction. The supernatant was discarded and the pellet suspended in $400 \mu \mathrm{L}$ AP1 and $80 \mu \mathrm{L}$ proteinase $\mathrm{K}(1 \mathrm{mg} / \mathrm{ml})$. This was incubated for 60 minutes at $65^{\circ} \mathrm{C}$ in a water bath and then disrupted using a TissueLyser II (Qiagen) for 4 minutes at $30 \mathrm{~Hz}$ with $3 \mathrm{~mm}$ tungsten carbide beads. The subsequent steps were followed according to the manufacturer's instructions, with the exception that QIAshredder column and second wash stage were omitted.

\section{Amplification and Sequencing: Illumina Miseq}

We amplified the DNA using the $r b c L$ DNA barcode marker region (CBOL Plant Working Group et al. 2009). Two rounds of PCR were carried out: a primary tailed amplification of the $r b c L$ region, followed by a second round of amplification that added the Illumina Nextera index adaptor sequences so that samples could be processed on Illumina platforms and be subsequently separated via bioinformatic processing. Samples were initially amplified using the universal primers $r b c L a f$ and $r b c L r 506$ (de Vere et al. 2012), to which adaptor 5 ' overhangs had been added:

(rbcLaf+adaptor:

TCGTCGGCAGCGTCAGATGTGTATAAGAGACAGATGTCACCACAAACAGAGA CTAAAGC

rbcLr506+adaptor:

GTCTCGTGGGCTCGGAGATGTGTATAAGAGACAGAGGGGACGACCATACTTG TTCA).

PCR was performed using a final volume of $20 \mu \mathrm{l}$. A mix of $10 \mu \mathrm{l}$ of $2 \mathrm{x}$ Phusion Mastermix (New England Biolabs), $0.4 \mu \mathrm{l}$ of forward primer (rbcLa-F), $0.4 \mu \mathrm{l}$ of reverse primer (rbcL506), and $7.2 \mu 1$ of molecular biology grade water was made, to which $2.0 \mu 1$ of template DNA was added. The PCR conditions were: $95^{\circ} \mathrm{C}$ for 2 minutes; $95^{\circ} \mathrm{C}$ for 30 seconds, $50^{\circ} \mathrm{C}$ for 1 minute 30 seconds, $72^{\circ} \mathrm{C}$ for 40 seconds ( 35 cycles); $72^{\circ} \mathrm{C}$ for 5 
minutes, $30^{\circ} \mathrm{C}$ for 10 seconds. We visualised the PCR products using agarose gel electrophoresis to confirm successful amplification.

Products from the first PCR were purified following Illumina's 16S Metagenomic Sequencing Library Preparation protocol (Illumina 2013) using Agencourt AMPure XP beads (Beckman Coulter). The Index PCR stage (following the Illumina protocol) used a $25 \mu 1$ reaction $(12.5 \mu 1$ of $2 x$ Phusion Mastermix, $2.5 \mu 1$ of Nextera XT i7 Index Primer, $2.5 \mu 1$ of Nextera XT i5 Index Primer, $5 \mu$ of PCR grade water, and $2.5 \mu 1$ of purified first-round PCR product). PCR clean-up 2 of the Illumina protocol was then followed, cleaning $20 \mu \mathrm{l}$ of Indexed PCR product, with a 1:0.8 ratio of product to AMPure XP beads.

Amplified products were quantified using a Qubit fluorescence spectrophotometer (Life Technologies) and pooled at equal concentrations to produce the final library. This was again quantified via Qubit to determine concentration and adjusted to $10 \mathrm{nM}$ concentration with $0.1 \mathrm{M}$ Tris- $\mathrm{HCl} / 0.01 \%$ Tween 20 solution prior to sequencing on an Illumina MiSeq platform. Library denaturation and sample loading steps followed the Illumina protocol: sample was loaded at 3pM concentration with $20 \%$ PhiX control spike and paired-end sequences generated in $2 \times 300 \mathrm{bp}$ format.

\section{Data Analysis}

We created a data analysis pipeline to process the Illumina sequence reads and to match them to known taxa within a local reference database. Files containing the sequence reads used in this study are available through the NCBI sequence read archive (SRA accession SRP076527). The source code and tools used for the pipeline are available on github at https://github.com/colford/nbgw-plant-illumina-pipeline. Sequences were quality trimmed and then merged with only sequences greater than $450 \mathrm{bp}$ used in downstream analysis.

We used a local BLAST database created from chloroplast sequence data from GenBank which included $r b c L$ sequences obtained from the Barcode Wales project, which provides 98\% coverage for the native flowering plants of Wales (de Vere et al. 2012). DNA sequences from the pollen samples were scored against the database using MegaBLAST. If the sequence top bit score matched to a single species, then the sequence was identified to that species. If the top bit score was the same for different species belonging to the 
same genus, then the result was given to genus. If the top bit score belonged to multiple genera within the same family then a family level designation was made. Sequences blasting to multiple families were considered to be unknown(Hawkins et al. 2015; de Vere et al. 2017). Results for each pollen sample were manually filtered so that only species recorded within the UK (Stace 2010) were retained.

\section{Statistical analysis}

We converted the number of DNA sequences for each insect to a percentage, to control for differences in DNA amplification between samples in the initial PCR. This can provide semi-quantitative data on the proportions of each pollen taxon (de Vere et al. 2017). However, we used qualitative data (presence/ absence) for the network analysis and investigation of differences in pollen loads, to avoid any bias caused by differences in pollen retrieval, DNA extraction, amplification and sequencing.

We investigated the pollen transport networks and interspecific differences in pollen loads using two complementary analyses. Interaction network metrics were analysed using the Bipartite Package (v. 2.05) in R version 3.0.1 (Dormann, Gruber \& Frund 2008; R Core Team 2014), including specialisation $\left(H_{2}{ }^{\prime}\right)$, which represents the overall level of specialisation of all species in a network, and varies from 0 (complete generalisation) to 1 (complete specialisation); and $d$ ', which measures how exclusive a given species' interactions are compared to the other species in a network, and varies from 0 (no exclusivity) to 1 (completely exclusive).

To test for differences in pollen load composition, we created a priori dummy variables representing each comparison arising from our hypothesis predictions (Cheilosia/all other genera; Eristalis/all other genera; Rhingia/all other genera; Sericomyia/all other genera; Volucella/all other genera). For the species-level analysis of six Eristalis species and two Sericomyia species (the two genera which had more than one species represented in our samples), comparisons were made within the two genera, and not with other species in this study. We then investigated the similarity between pollen loads between genera and species using the Jaccard similarity index (Jaccard 1901), with statistical differences in pollen loads assessed using adonis, a permutational MANOVA procedure in the $\mathrm{R}$ package 'vegan' version 2.4-3 (Oksanen et al. 2013), using 9999 permutations. Since this 
index is based on species presence - absence, it can overemphasise the significance of rare taxa. To avoid this, we calculated the index based on the data excluding sequences identified to taxa above genus which contributed less than $1 \%$ of all sequences. Unidentified sequences were also excluded from the analysis. To correct for multiple comparisons in comparing each genus against all of the other hoverflies, we used the Dunn-Šidák correction. To account for the lack of independence of insects collected within the same site, we used the strata argument in adonis, which is similar to a random effect in a mixed-effects model.

\section{Results}

\section{Overview}

We sequenced pollen loads from 143 hoverflies of 11 species (Cheilosia illustrata, Eristalis arbustorum, E. horticola, E. intricaria, E. nemorum, E. pertinax, E. tenax, Rhingia campestris, Sericomyia silentis, S. superbiens, and Volucella bombylans) (table 1 and figure 1). A total of 1,810,674 sequences over $450 \mathrm{bp}$ in length could be attributed to tagged sequences of $r b c L$. Of these, 1,791,574 (98.9\%) could be identified to plants at species, genus or family level. We identified 58 plant taxa from pollen retrieved from all 11 hoverfly species, consisting of 21 species, 22 genera and 15 families (figures $1-4$ and Appendix 3). Plant species richness (table 1) was comparable at each site, ranging from 64 to 75. A list of the plant species recorded at each site is given in Appendix 2.

The proportions of sequences (percentages) for each plant taxa recovered varied between hoverfly species. The sequences contributing $5 \%$ or more for a species are shown in figure 1, whilst the network figures $2-4$ show all plant pollen taxa recovered from hoverflies at each site. Pollen sequences from Cheilosia illustrata were predominantly from Calluna vulgaris and Succisa pratensis, with lesser amounts of Rubus fruticosus agg. and Cardueae. Eristalis species carried a number of pollen taxa, with sequences from the Cardueae, Rubus fruticosus agg., and S. pratensis predominating, although Hypericum species were also a significant proportion of the pollen load on E. arbustorum and, to a lesser extent, E. horticola. Apiaceae were the most frequently recorded sequences carried by Rhingia campestris with smaller amounts of both Cardueae, Rubus fruticosus agg. and Brassicaeae. Both Sericomyia silentis and S. superbiens sequences 
came predominantly from Rubus fruticosus agg. pollen. However, S. silentis also favoured Cardueae and, to a lesser extent, Apiaceae, whilst $S$. superbiens had smaller amounts of both Calluna vulgaris and Succisa pratensis. Volucella bombylans pollen sequences consisted mainly of Calluna vulgaris, Succisa pratensis and Cardueae, with smaller amounts of Cichoreae and Eupatorium cannabinum.

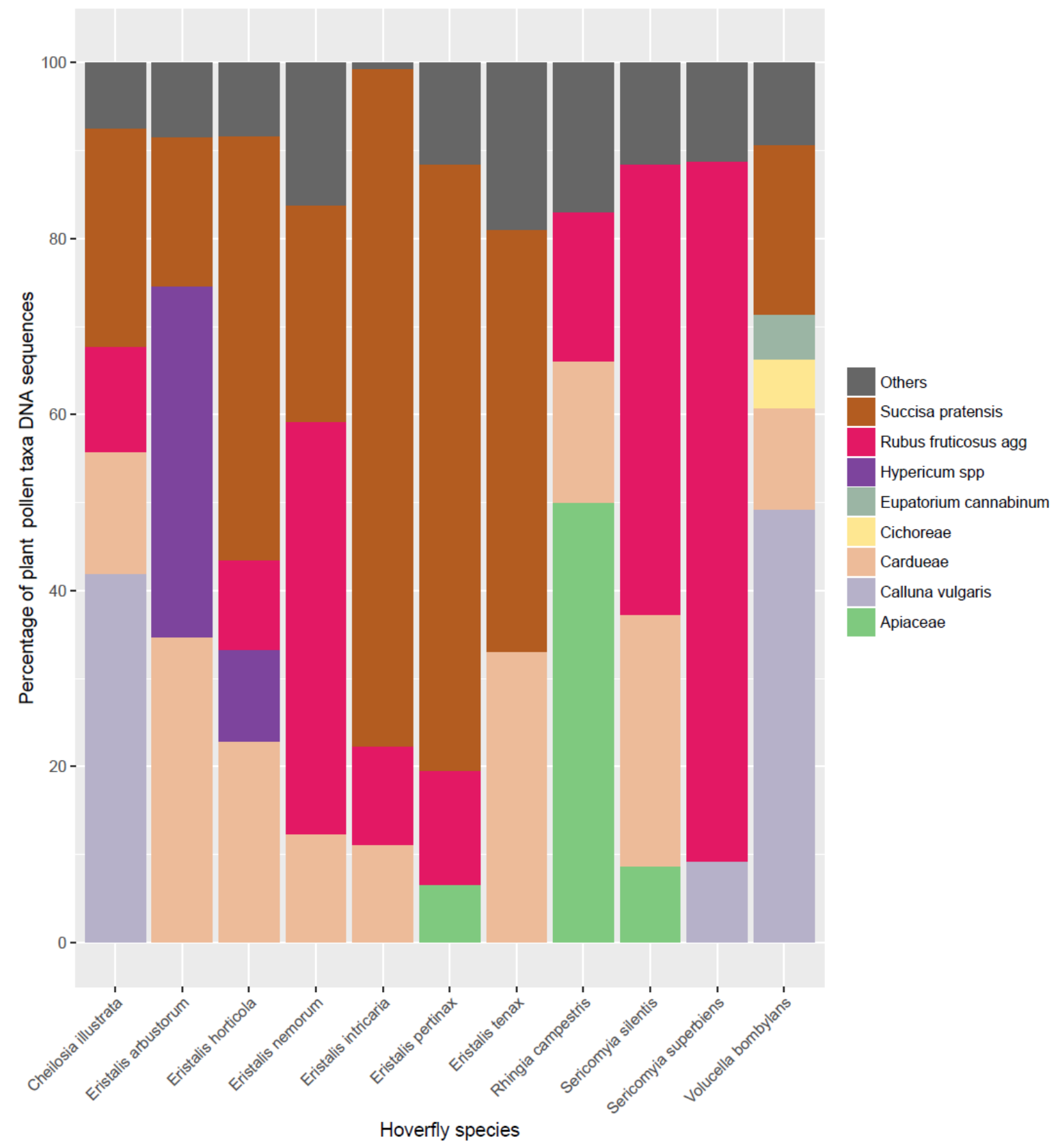

Figure 13 Mean \% of plant taxa pollen DNA sequences retrieved from pollen loads carried by 11 hoverfly species at three grasslands in west Wales, July - August 2014. 


\section{For clarity, all plant taxa contributing less than $\mathbf{5 \%}$ of sequences for a hoverfly species have been combined as 'Others'.}

The number of entomophilous plant species at each site, and the number of those species that were also recorded in pollen samples from all hoverflies is also shown in table 2. The proportion of entomophilous species at each site also recorded as present in pollen were 13/33 (39\%) at site CAD, $17 / 39(44 \%)$ at site LLC, and 13/31 (42\%) at site TRE.

\section{Pollination Network Structures}

The network metrics are given in table 1, with the networks themselves illustrated in figure $2-4$. The network specialisation metric $H_{2}$ ' (table 1 ) is a measure of overall generalisation or specialisation of a network, and ranges from 0 (perfect generalisation) to 1 (perfect specialisation). The values of $H_{2}$ ' for the networks at each site in our study had values below 0.5 , ranging from 0.12 (LLC) to 0.24 (TRE). This indicates that the pollen transport networks at the site level were more generalised in their structure than specialised (Bluthgen, Menzel \& Bluthgen 2006), with plants having multiple hoverfly species transporting their pollen, and hoverfly species in turn visiting multiple plant species (see also figures $2-4$ ) .

The network metric $d$ ' (table 1) measures the degree of exclusivity in a species' interactions in a network, and ranges from 0 (no exclusivity) to 1 (complete exclusivity). The range of values of $d$ ' for all Eristalis species combined were relatively low (mean = 0.08 , range $0-0.19$ ) indicating that few interactions were unique to these species. However, results amongst other species had some higher values of $d$ ', notably for Rhingia campestris $($ median $=0.19$, range $0.15-0.37)$. However, a Kruskall - Wallis test of all values of d' showed no significant difference between species $\left(\mathrm{X}^{2}=16.23, p=0.09\right)$. The number of exclusive interactions by species was therefore low, with no difference in exclusivity between species. The generalisation of whole networks and the lack of exclusive interactions at the species level are further illustrated by the network diagrams for each site shown in figures 2, 3 and 4 . These show all plant pollen taxon groups that were identified as part of this study at each site, and the presence or absence of pollen taxa carried by each hoverfly species. 
Table 8 Values of $\mathrm{H}_{2}{ }^{\prime}$, plant species richness, entomophilous plant species richness, number of entomc number of pollen taxa, and values of $d$ ' for pollen loads carried by $\mathbf{1 1}$ species of hoverfly at three gras: August 2014

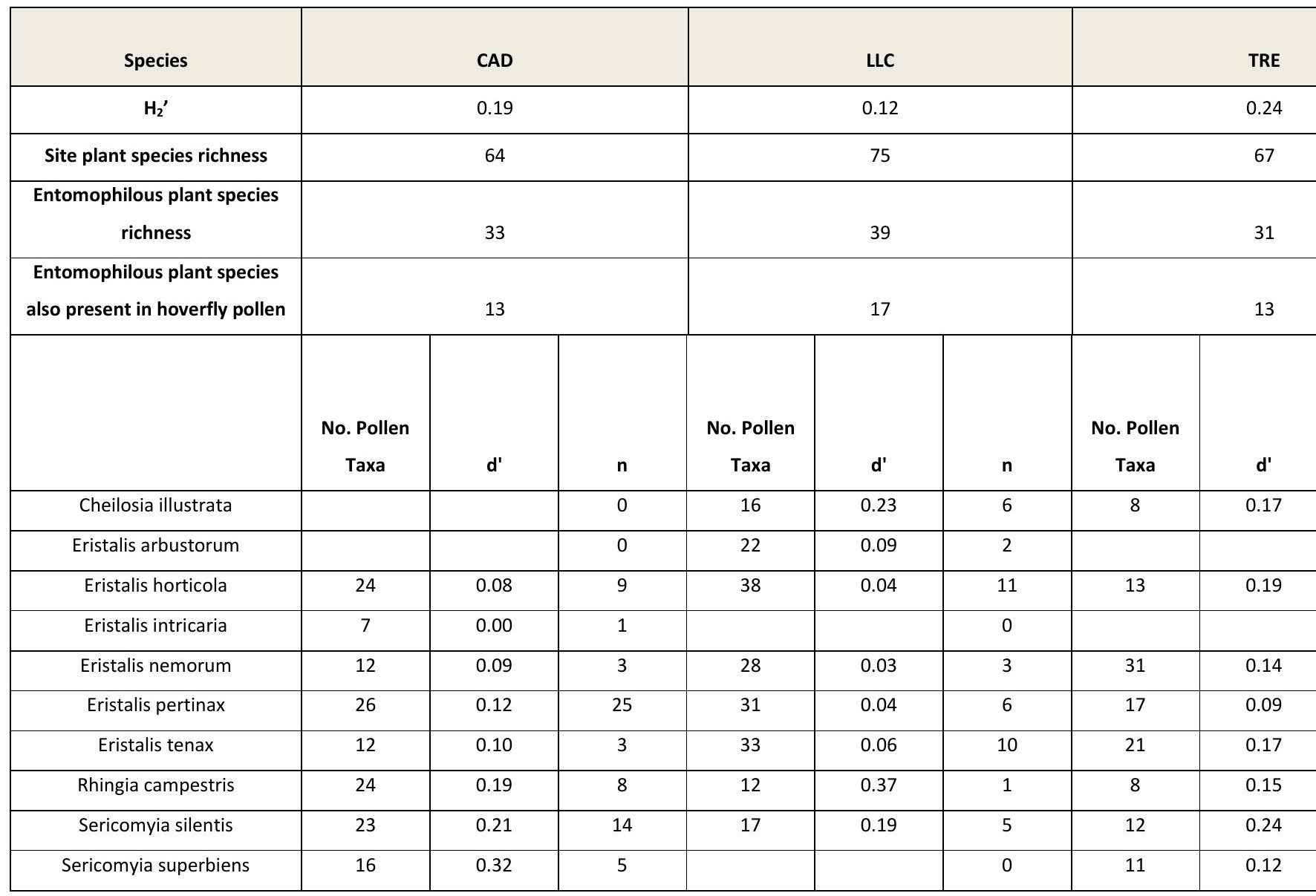




\begin{tabular}{|c|c|c|c|c|c|c|}
\hline Volucella bombylans & 10 & 0.15 & 1 & 0 & 15 & 0.20 \\
\hline Total $\mathbf{n}$ & & & 69 & 44 & & \\
\hline
\end{tabular}




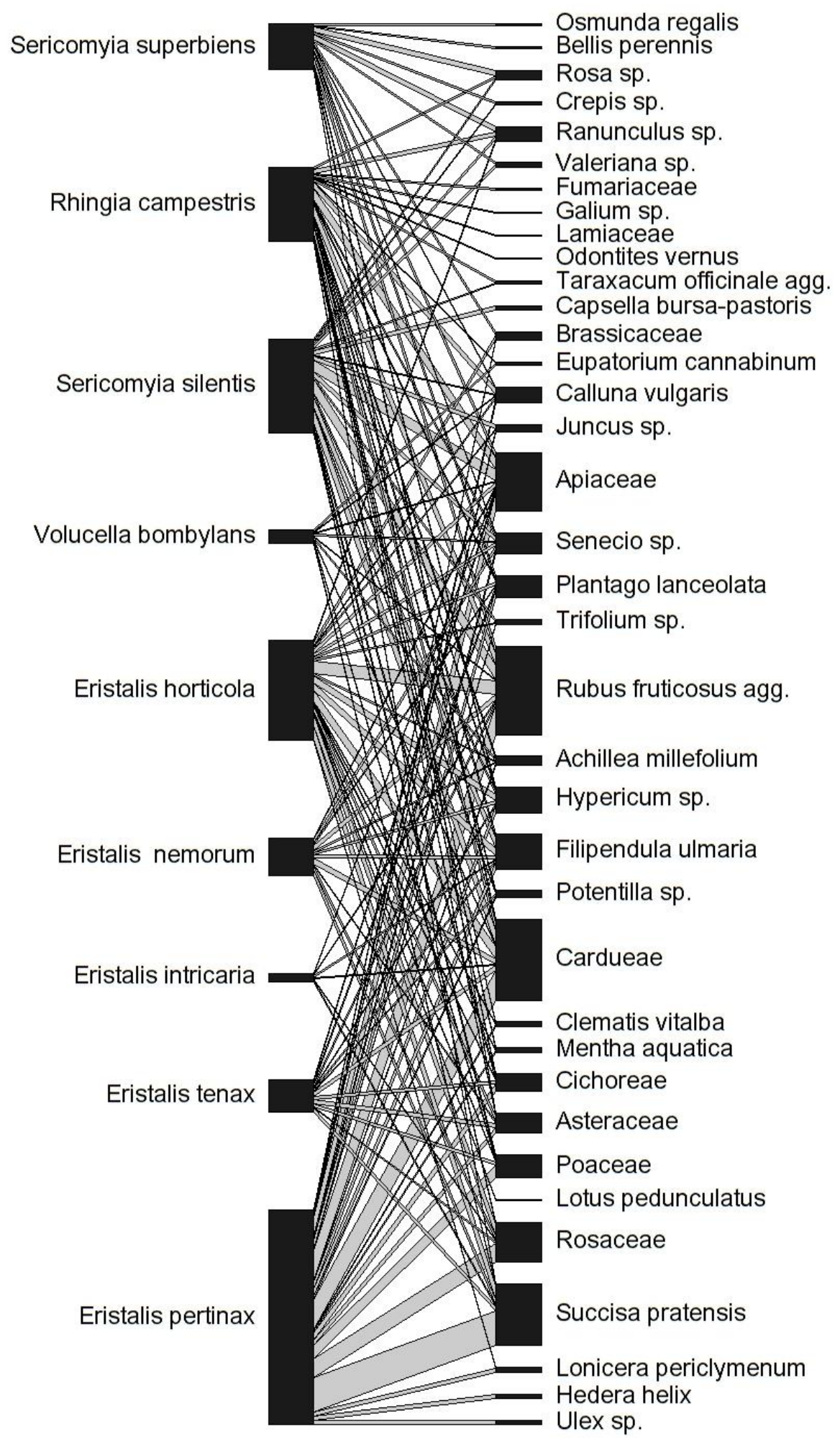

Figure 14 Pollen transport network derived from analysis of pollen carried by hoverflies at site CAD, July - August 2014. The length of the hoverfly and plant taxon bars indicates the proportion of the respective taxa in the study, and the width of the connecting ribbon represents the strength of the interaction. 


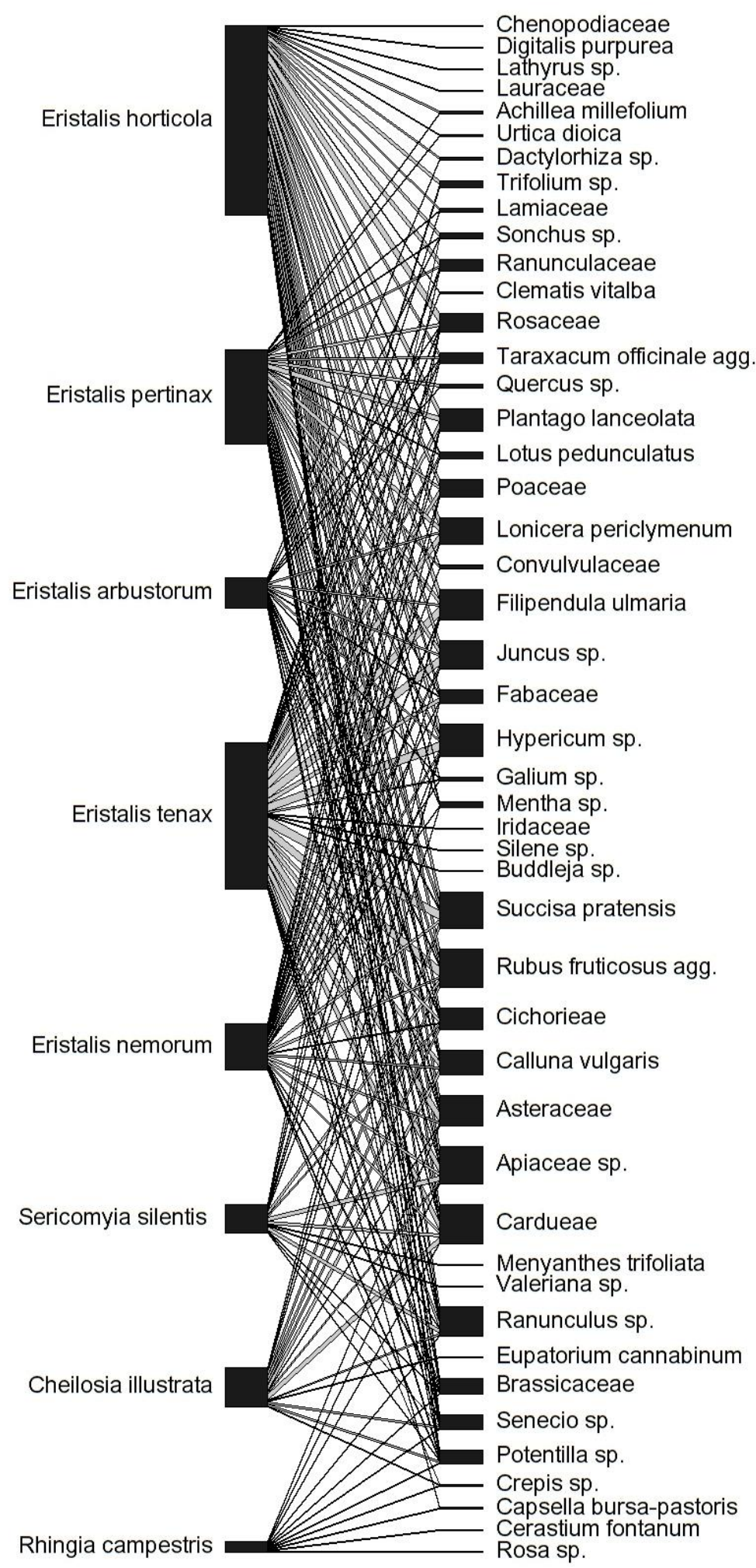

Figure 15 Pollen transport network derived from analysis of pollen carried by hoverflies at site LLC, July - August 2014. The length of the hoverfly and plant taxon bars indicates the proportion of the respective taxa in the study, and the width of the connecting ribbon represents the strength of the interaction. 


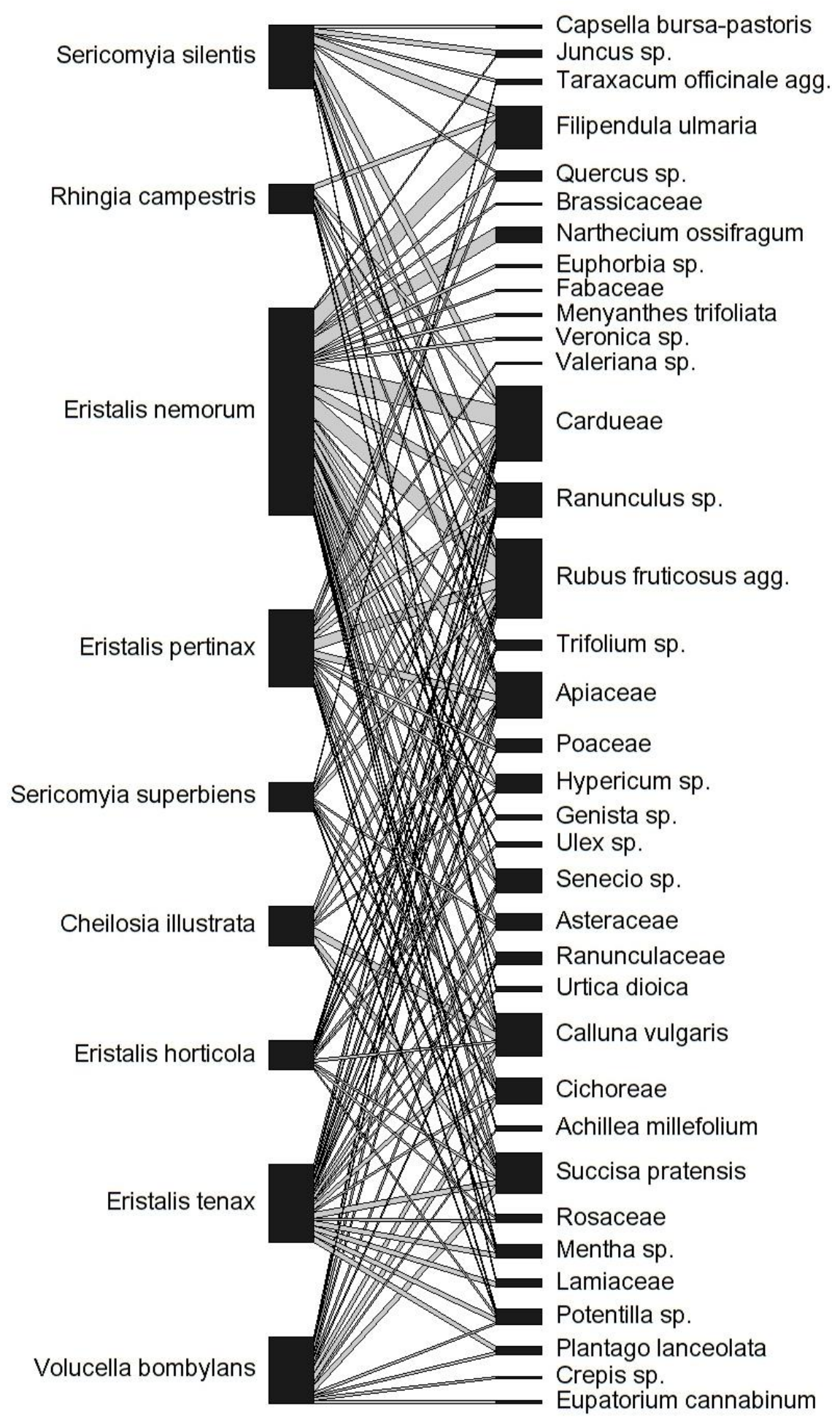

Figure 16 Pollen transport network derived from analysis of pollen carried by hoverflies at site TRE, July - August 2014. The length of the hoverfly and plant taxon bars indicates the proportion of the respective taxa in the study, and the width of the connecting ribbon represents the strength of the interaction. 


\section{Pollen Load Differences - Genera and Species}

Having found very few exclusive interactions, we then tested for differences among taxa in pollen load composition, as measured by mean pairwise comparisons between individuals using the Jaccard Similarity Index. We initially investigated whether a significant difference existed between pollen loads of the five hoverfly genera in this study, using an adonis (permutational MANOVA) analysis. We found that there is a significant difference between hoverfly genera overall $\left(\mathrm{F}_{(4,142)}=9.860, \mathrm{R}^{2}=0.222, p=\right.$ $0.0001)$.

To explore specifically where these differences were, we then ran five separate analyses comparing each genus with the remaining four genera. We used the Dunn-Šidák correction to correct for multiple comparisons, yielding a $p$-value significance cut-off of 0.0073008 . We found that each genus carried pollen loads with significantly distinct species composition, compared to all other hoverfly genera, with the exception of Volucella which was not significant when correcting for multiple comparisons (Table 2).

Table 9 Comparison of the pollen loads of five hoverfly genera using the Jaccard

Similarity Index. One species was tested for Cheilosia, Rhingia and Volucella, and therefore the species name is given. The analysis used the Dunn-Šidák correction for

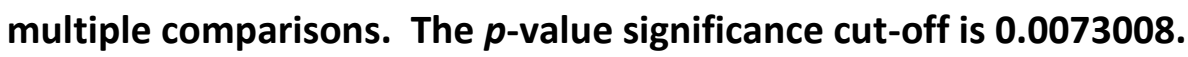

\begin{tabular}{|c|c|c|c|}
\hline Species/Genus & F & R2 & $\begin{array}{c}\text { Unadjusted } \\
\boldsymbol{p} \text { value }\end{array}$ \\
\hline Cheilosia illustrata & 5.895 & 0.04 & $0.0001^{*}$ \\
\hline Eristalis species & 15.568 & 0.099 & $0.0001^{*}$ \\
\hline Rhingia campestris & 7.147 & 0.048 & $0.0001^{*}$ \\
\hline Sericomyia species & 16.24 & 0.103 & $0.0001^{*}$ \\
\hline Volucella bombylans & 3.115 & 0.022 & 0.013 \\
\hline
\end{tabular}


At the species level, in an initial analysis comparing all eleven species, there was a significant difference in pollen load composition $\left(\mathrm{F}_{(10,142)}=6.335, \mathrm{R}^{2}=0.324, p=\right.$ 0.0001). We then investigated whether there were significant differences in pollen load composition between the species in the two genera for which there were multiple species. For the six Eristalis species, there was a significant difference in pollen load composition $\left(\mathrm{F}_{(5,87)}=2.972, \mathrm{R}^{2}=0.153, p=0.033\right)$. This was contrary to our prediction of no significant difference. For the two Sericomyia species there was also a significant difference in pollen loads $\left(\mathrm{F}_{(1,30)}=3.695, \mathrm{R}^{2}=0.113, p=0.016\right)$. This confirmed our prediction of a significant difference in pollen loads between species.

\section{Discussion}

The eleven hoverfly species in this study form a pollinator community that is relatively generalised, both in terms of overall network structure and individual species. Although a large number of taxa were recorded from pollen removed from hoverflies, there were few exclusive hoverfly/pollen taxa interactions, with the main constituents of the pollen loads of all species being relatively similar. Nonetheless, there were significant differences in the composition of pollen loads among hoverfly species, which suggests they may fulfil complementary pollination roles in the grassland habitats we studied.

A relatively generalised structure is a consistent feature of pollinator visitation networks found in other ecosystems, such as arable habitats (Rollin et al. 2016), heathlands (Ballantyne, Baldock \& Willmer 2015), urban areas (Baldock et al. 2015), and Mediterranean grasslands (Banza, Belo \& Evans 2015). In these systems, plants have a number of pollinators, and pollinators, in turn, visit a number of different plant species. The pollen transport networks of hoverfly communities at our sites showed a similar pattern, with $\mathrm{H}_{2}$ ' values lower than 0.5 , indicating a structure closer to generalisation than specialisation.

The network metric $d$ ' measures the degree of specialisation, in terms of exclusive interactions, at the species level. Values of $d$ 'were especially low for the Eristalis species, indicating low levels of specialisation. This was unsurprising given the morphological similarity of the species in this genus, which have been noted visiting a comparable suit of plant species (Stanley, Gunning \& Stout 2013). The slightly higher values of $d$ ' amongst non-Eristalis hoverfly species is of note, particularly that of Rhingia 
campestris which may indicate a small degree of exclusivity in their pollen loads (Bluthgen, Menzel \& Bluthgen 2006). However, values of $d$ ' are still less than 0.5 , and there was no significant difference in the values of $d$ ' between species. Overall, pollen transport networks amongst hoverflies at our sites were characterised by generalisation at the species level.

Differences in the value of $d$ ' reflect the degree of exclusive interactions of a particular species. Hoverflies at our sites carried pollen predominantly drawn from a suite of 8 plant taxonomic groups (Apiaceae, Calluna vulgaris, Cardueae, Cichoreae, Eupatorium cannabinum, Hypericum species, Rubus fruticosus agg. and Succisa pratensis (figure 1), many of which were visited by multiple hoverfly species. However, there were significant differences in interspecific pollen loads between all genera in our study, with the exception of $V$. bombylans, and between species in the genera Eristalis and Sericomyia. This suggests some degree of floral resource partitioning by adult hoverflies at our sites.

Previous work gives some limited evidence of niche partitioning in hoverflies (Branquart \& Hemptinn 2000). Temporal niche segregation has been observed in adult Copestylum hoverflies in desert environments (Martinez-Falcon, Marcos-Garcia \& Moreno 2011), and Fründ et al. (Fründ, Linsenmair \& Blüthgen 2010) found evidence of differences in flower preference in four species of adult hoverflies: Episyrphus balteatus, Eristalis tenax, Syritta pipiens and Sphaerophoria scripta. However, in many pollination studies, resource partitioning is recorded at a higher taxonomic level than species, with hoverflies frequently considered together as a single functional group (Dicks, Corbet \& Pywell 2002; Venjakob et al. 2016). Resource partitioning has also been previously noted in a range of pollinators, including bumblebees (Scriven et al. 2016), mixed bee communities, (Carvalho, Presley \& Santos 2014), birds (Maglianesi, Bohning-Gaese \& Schleuning 2015) and bats (Clairmont, Mora \& Fenton 2014). Our results demonstrate significant differences in the proportions of pollen taxa in the pollen loads of hoverfly genera and species, and suggest that treating hoverflies as a single functional group may overlook the complementary pollination role between hoverfly species. 
A number of processes may be leading to differences in pollen loads between species. These include innate differences in flower choice (Inouye et al. 2015), agonistic interactions between hoverfly species, or interactions between hoverflies and other pollinator guilds (Morse 1981; Dworschak \& Bluthgen 2010). Plant species can vary in the energy content of their nectar (Baude et al. 2016), and there is some limited evidence of differences in hoverfly metabolism between species (Tomlinson \& Menz 2015). There is also a wide variation in the proboscis length in the species in this study (Ssymank 1991), ranging from $3.3 \mathrm{~mm}$ (Cheilosia illustrata), to 10.6mm (Rhingia campestris) which could result in differences in plant visitation. Differences in the composition of pollen loads may therefore be arising from a combination of morphology, differing physiological requirements between species, behaviour, and interaction with other pollinator species. Understanding the mechanisms behind resource partitioning in hoverfly pollen loads is critical, because pollinator species diversity is a key factor in the functioning of pollination as an ecosystem service (Burkle \& Alarcón 2011; Gill et al. 2016).

Overall, 59 plant pollen taxa were recorded on hoverflies at our field sites. Whilst some of these categories may represent duplicates (e.g. pollen identified either as Rubus fruticosus agg. or as 'Rosaceae'), some categories will include several species (e.g. 'Apiaceae'). Morris (1998), lists 188 plants visited by all hoverfly species in Surrey in southern England. Our study, based on eleven species in three fields in west Wales, suggests that the range of plants visited by hoverflies is far wider than previously appreciated. Hoverflies were transporting pollen from between $39 \%$ and $44 \%$ of entomophilous plant species recorded at our sites. This result should be interpreted with care, because some entomophilous plant species (e.g. Prunus spinosa and Crategus monogyna) would not have been flowering at the time of the study. Hoverflies also carried pollen from anemophilous species, such as grasses. Pollen from such species has been found in the diet of some hoverflies (Ssymank \& Gilbert 1993) and bee pollen loads (de Vere et al. 2017), although whether this constitutes a significant role pollination function is unclear (Inouye et al. 2015). In addition, the data used to compile the plant species list was originally collected to characterise the grassland communities, and not to provide an exhaustive site species list. However, hoverflies are potentially transporting the pollen from a significant proportion of the entomophilous plant community on our sites. Further work is needed, combining pollen load information with contemporaneous 
data on plant flowering, to fully assess the potential contribution of hoverflies to pollination.

The pollen loads for Cheilosia illustrata in this study are notable for the scarcity of Heracleum sphondylium, as the larvae feed exclusively on this species (Stubbs \& Falk 2002). Observations of other Cheilosia species have shown this genus visits a range of species (Radisic et al. 2001). Our results for C. illustrata recorded C. vulgaris, Cardueae, $S$. pratensis and $R$. fruticosus agg. pollens, together with a small amount of Apiaceae pollen, which may represent $H$. sphondylium . The genus Eristalis (principally E. tenax) is one of the most well-studied hoverfly genera, recorded visiting a range of plant species (Jarlan, De Oliveira \& Gingras 1997). In this study, the pollens most frequently recovered from Eristalis species were S. pratensis, R. fruticosus agg., and Cardueae species. The pollen loads of $R$. campestris were of particular interest, as the genus has long mouth parts, making many tubular flowers accessible to this species (van der Kooi et al. 2016). However, loads on this species were distinctive for their high proportion of Apiaceae pollen, a plant family with open, readily accessible inflorescences utilised by a number of hoverfly species (Branquart \& Hemptinn 2000). The species $S$. silentis and $S$. superbiens have differences in status in Britain; S. silentis is relatively common, whilst $S$. superbiens is a localised species primarily found in the west and north (Ball et al. 2011). Sericomyia silentis has been noted as a visitor to a number of plant species, including Ericaceae, Asteraceae and Apiaceae (Morris 1998). In this study, S. silentis pollen loads consisted predominantly of $R$. fruticosus agg. with lesser amounts of Cardueae pollen. In Estonia, S. superbiens fed on Centaurea and Sonchus species (Dlusskii \& Lavrova 2001), but although Asteraceae were present on our sites, S. superbiens pollen loads consisted mainly of $R$. fruticosus with some $C$. vulgaris and $S$. pratensis. The final species, $V$. bombylans, has been observed visiting domestic Rubus species (Prodorutti \& Frilli 2008), whilst other Volucella species have been recorded visiting a range of flowers, including Calluna vulgaris (Descamps et al. 2015). In our study, it was the only species where the highest percentage of pollen carried came from Calluna vulgaris together with S. pratensis.

This study was concerned with eleven hoverfly species that are, with the exception of $R$. campestris, relatively large wasp or bee mimics (Stubbs \& Falk 2002). However, hoverflies are a diverse family, which in Britain includes small species, such as the genus 
Neoascia (Olesen \& Warncke 1989) or species that are morphologically uniform with little or no mimicry of hymenoptera, such as many Cheilosia species (Radisic et al. 2001). Moreover, this study was limited to a short period in late summer at three sites. The evidence of resource partitioning found amongst the hoverfly species in our study, and of involvement with a high proportion of plant taxa invites further investigation to determine how the full diversity of the hoverfly fauna contributes to pollination. Understanding the full role of hoverflies in plant pollinator interactions is important because flower visitation by hoverflies may be complementary to bees, taking place when the resource is unavailable to other pollinators, not least because air temperature can influence both insect activity and nectar concentration (Inouye et al. 2015). These seasonal and diel effects may have a key influence on flower visitation and potential pollination by hoverflies. Pollination networks can also vary in their structure between years, so that observations over a number of field seasons is required to fully describe how insect communities deliver a pollination ecosystem service (Alarcón, Waser \& Ollerton 2008).

Similarly, further examination is required of the role of hoverflies in the function of grassland systems. Whilst most pollen carried by hoverflies was from a small number of common plant taxa, these plants may be supporting diverse pollinator communities that, in turn, can occasionally pollinate scarce plant species (Seifan et al. 2014). The many pollen taxa carried by hoverflies at low levels may represent a significant role in the pollination of scarcer plant species, and thus in wider ecosystem function.

Numerous authors have noted that pollen transport is not equivalent to pollination (King, Ballantyne \& Willmer 2013; Popic, Wardle \& Davila 2013; Armbruster 2016). Networks may appear to be generalised due to a large number of potential pollinators visiting plants, but this can resolve into a much more specialised network when pollination effectiveness, as opposed to pollen transport, is taken into account (Ballantyne, Baldock \& Willmer 2015). Our results demonstrate the role of hoverflies in pollen transport in grassland ecosystems, but further study is required to fully describe both hoverfly foraging ecology and pollination networks.

In pollination studies hoverflies are frequently considered to be a single functional group, in comparison to other pollinator taxa (Feltham et al. 2015). Our study demonstrates that, 
whilst there is some overlap in the pollen taxa transported by hoverfly species, there are differences in the composition of pollen loads between species, indicating that hoverfly species may perform subtly different pollination functions. Although it may not always be practical to identify hoverflies to species in field studies, this specialisation should be considered when assessing the value of management interventions for pollinators. This study is one of the first to use DNA metabarcoding to investigate a Dipteran pollinator community, and adds to our understanding of the role of hoverflies in pollen transport and the functioning of conservation grassland habitats.

\section{References}

Alarcón, R., Waser, N.M. \& Ollerton, J. (2008) Year-to-year variation in the topology of a plant-pollinator interaction network. Oikos, 117, 1796-1807.

Ambrosino, M.D., Luna, J.M., Jepson, P.C. \& Wratten, S.D. (2006) Relative Frequencies of Visits to Selected Insectary Plants by Predatory Hoverflies (Diptera: Syrphidae), Other Beneficial Insects, and Herbivores. Environmental Entomology, 35, $394-400$.

Armbruster, W.S. (2016) The specialization continuum in pollination systems: diversity of concepts and implications for ecology, evolution and conservation. Functional Ecology 31: 88-100. doi:10.1111/1365-2435.12783

Baldock, K.C.R., Goddard, M.A., Hicks, D.M., Kunin, W.E., Mitschunas, N., Osgathorpe, L.M., Potts, S.G., Robertson, K.M., Scott, A.V., Stone, G.N., Vaughan, I.P. \& Memmott, J. (2015) Where is the UK's pollinator biodiversity? The importance of urban areas for flower-visiting insects. Proceedings of the Royal Society of London B: Biological Sciences, 282 20142849; DOI: 10.1098/rspb.2014.2849.

Ball, S., Morris, R., Rotheray, G. \& Watt, K. (2011) Atlas of the Hoverflies af Great Britain (Diptera, Syrphidae). Wallingford,Biological Records Centre

Ballantyne, G., Baldock, K.C.R. \& Willmer, P.G. (2015) Constructing more informative plant-pollinator networks: visitation and pollen deposition networks in a heathland plant community. Proceedings of the Royal Society of London B: 
Biological Sciences, 282 20151130; DOI: 10.1098/rspb.2015.1130. Published 2 September 2015

Banza, P., Belo, A.D.F. \& Evans, D.M. (2015) The structure and robustness of nocturnal Lepidopteran pollen-transfer networks in a Biodiversity Hotspot. Insect Conservation and Diversity, 8, 538-546.

Bascompte, J., Jordano, P., Melian, C.J. \& Olesen, J.M. (2003) The nested assembly of plant-animal mutualistic networks. Proceedings of the National Academy of Sciences of the United States of America, 100, 9383-9387.

Baude, M., Kunin, W.E., Boatman, N.D., Conyers, S., Davies, N., Gillespie, M.A.K., Morton, R.D., Smart, S.M. \& Memmott, J. (2016) Historical nectar assessment reveals the fall and rise of floral resources in Britain. Nature, 530, 85-88.

Bell, K.L., de Vere, N., Keller, A., Richardson, R.T., Gous, A., Burgess, K.S. \& Brosi, B.J. (2016) Pollen DNA barcoding: current applications and future prospects. Genome, 59, 1-12.

Bell, K.L., Fowler, J., Burgess, K.S., Dobbs, E.K., Gruenewald, D., Lawley, B., Morozumi, C. \& Brosi, B.J. (2017) Applying pollen DNA metabarcoding to the study of plant-pollinator interactions. Applied Plant Science, 5. 5(6):1600124 https://doi.org/10.3732/apps.1600124

Bevan, J.M.S., Motley, G.S., Stevens, D.P. \& Bosanquet, S.D.S. (2006) A vegetation survey and conservation assessment of lowland grasslands in Dinefwr. Countryside Council for wales, Bangor.

Birtele, D. \& Hardersen, S. (2012) Analysis of vertical stratification of Syrphidae (Diptera) in an oak-hornbeam forest in northern Italy. Ecological Research, 27, 755-763.

Bluthgen, N., Menzel, F. \& Bluthgen, N. (2006) Measuring specialization in species interaction networks. BMC Ecology, 6: 9. https://doi.org/10.1186/1472-6785-6-9

Branquart, E. \& Hemptinn, J. (2000) Selectivity in the exploitation of floral resources by hoverflies (Diptera: Syrphinae). Ecography, 23, 732 - 742.

Burkle, L.A. \& Alarcón, R. (2011) The future of plant-pollinator diversity: Understanding interaction networks acrosss time, space, and global change. American Journal of Botany, 98, 528-538. 
CaraDonna, P.J., Petry, W.K., Brennan, R.M., Cunningham, J.L., Bronstein, J.L., Waser, N.M. \& Sanders, N.J. (2017) Interaction rewiring and the rapid turnover of plantpollinator networks. Ecology Letters 20: 385-394. doi:10.1111/ele.12740

Carvalho, D.M., Presley, S.J. \& Santos, G.M.M. (2014) Niche Overlap and Network Specialization of Flower-Visiting Bees in an Agricultural System. Neotropical Entomology, 43, 489-499.

CBOL Plant Working Group, Hollingsworth, P.M., Forrest, L.L., Spouge, J.L., Hajibabaei, M., Ratnasingham, S., van der Bank, M., Chase, M.W., Cowan, R.S., Erickson, D.L., Fazekas, A.J., Graham, S.W., James, K.E., Kim, K.-J., Kress, W.J., Schneider, H., van AlphenStahl, J., Barrett, S.C.H., van den Berg, C., Bogarin, D., Burgess, K.S., Cameron, K.M., Carine, M., Chacón, J., Clark, A., Clarkson, J.J., Conrad, F., Devey, D.S., Ford, C.S., Hedderson, T.A.J., Hollingsworth, M.L., Husband, B.C., Kelly, L.J., Kesanakurti, P.R., Kim, J.S., Kim, Y.-D., Lahaye, R., Lee, H.-L., Long, D.G., Madriñán, S., Maurin, O., Meusnier, I., Newmaster, S.G., Park, C.-W., Percy, D.M., Petersen, G., Richardson, J.E., Salazar, G.A., Savolainen, V., Seberg, O., Wilkinson, M.J., Yi, D.-K. \& Little, D.P. (2009) A DNA barcode for land plants. Proceedings of the National Academy of Sciences, 106, 12794-12797.

Chandler, P., J. (2017) An Update of the 1998 Checklist of Diptera of the British Isles [updated 16 January 2017]. pp.

http://www.dipteristsforum.org.uk/documents/BRITISH_ISLES_CHECKLIST.pd f.

Clairmont, L., Mora, E.C. \& Fenton, B. (2014) Morphology, Diet and Flower-visiting by Phyllostomid Bats in Cuba. Biotropica, 46, 433-440.

Creer, S., Deiner, K., Frey, S., Porazinska, D., Taberlet, P., Thomas, W.K., Potter, C. \& Bik, H.M. (2016) The ecologist's field guide to sequence-based identification of biodiversity. Methods in Ecology and Evolution 7: 1008-1018. doi:10.1111/2041210X.12574

de Vere, N., Jones, L., Gilmore, T., Moscrop, J., Lowe, A., Smith, D., Hegarty, M., Creer, S. \& Ford, C. (2017) Using DNA metabarcoding to investigate honey bee foraging reveals limited flower use despite high floral availability. Scientific Reports, 7:42838. doi: 10.1038/srep42838. 
de Vere, N., Rich, T.C.G., Ford, C.R., Trinder, S.A., Long, C., Moore, C.W.,

Satterthwaite, D., Davies, H., Allainguillaume, J., Ronca, S., Tatarinova, T., Garbett, H., Walker, K. \& Wilkinson, M.J. (2012) DNA Barcoding the Native Flowering Plants and Conifers of Wales. Plos One, 7(6): e37945. https://doi.org/10.1371/journal.pone.0037945

Descamps, C., Moquet, L., Migon, M. \& Jacquemart, A.L. (2015) Diversity of the Insect Visitors on Calluna vulgaris (Ericaceae) in Southern France Heathlands. Journal of Insect Science, 15, 5.

Dicks, L.V., Abrahams, A., Atkinson, J., Biesmeijer, J., Bourn, N., Brown, C., Brown, M.J.F., Carvell, C., Connolly, C., Cresswell, J.E., Croft, P., Darvill, B., De Zylva, P., Effingham, P., Fountain, M., Goggin, A., Harding, D., Harding, A., Hartfield, C., Heard, M.E., Heathcote, R., Heaver, D., Holland, J., Howe, M., Hughes, B., Huxley, Y., Kunin, W.E., Little, J., Mason, C., Memmott, J., Osborne, J., Pankhurst, T., Paxton, R.J., Pocock, M.J.O., Potts, S.G., Power, E.F., Raine, N.E., Ranelagh, E., Roberts, S., Saunders, R., Smith, K., Smith, R.M., Sutton, P., Tilley, L.A.N., Tinsley, A., Tonhasca, A., Vanbergen, A.J., Webster, S., Wilson, A. \& Sutherland, W.J. (2013) Identifying key knowledge needs for evidence-based conservation of wild insect pollinators: a collaborative cross-sectoral exercise Insect Conservation and Diversity, 6, 435 - 446.

Dicks, L.V., Corbet, S.A. \& Pywell, R.F. (2002) Compartmentalization in plant-insect flower visitor webs. Journal of Animal Ecology, 71, 32-43.

Dlusskii, G.M. \& Lavrova, N.V. (2001) Comparison of imaginal diets of various Syrphidae (Diptera) species. Zhurnal Obshchĕ̌ Biologii, 62, 57-65.

Dormann, C.F., Gruber, B. \& Frund, J. (2008) Introducing the bipartite package: analysing ecological networks. $R$ News, 8, 8 - 11.

Dworschak, K.A.I. \& Bluthgen, N. (2010) Networks and dominance hierarchies: does interspecific aggression explain flower partitioning among stingless bees? Ecological Entomology, 35, 216-225.

Feltham, H., Park, K., Minderman, J. \& Goulson, D. (2015) Experimental evidence that wildflower strips increase pollinator visits to crops. Ecology and Evolution, 5, 3523-3530.

Fort, H., Vázquez, D.P. \& Lan, B.L. (2016) Abundance and generalisation in mutualistic networks: Solving the chicken-and-egg dilemma. Ecology Letters, 19, 4-11. 
Fründ, J., Linsenmair, K.E. \& Blüthgen, N. (2010) Pollinator diversity and specialization in relation to flower diversity. Oikos, 119, 1581-1590.

Garibaldi, L., Steffan-Dewenter, I., Winfree, R., Aizen, M., Bommarco, R., Cunningham, S., Kremen, C., Carvalheiro, L., Harder, L., Afik, O., Bartomeus, I., Benjamin, F., Boreux, V., Cariveau, D., Chacoff, N., Dudenhoffer, J., Freitas, B., Ghazoul, J., Greenleaf, S., Hipolito, J., Holzschuh, A., Howlett, B., Isaacs, R., Javorek, S., Kennedy, C., Krewenka, K., Krishnan, S., Mandelik, Y., Mayfield, M., Motzke, I., Munyuli, T., Nault, B., Otieno, M., Petersen, J., Pisanty, G., Potts, S., Rader, R., Ricketts, T., Rundlof, M., Seymour, C., Schuepp, C., Szentgyorgyi, H., Taki, H., Tscharntke, T., Vergara, C., Viana, B., Wanger, T., Westphal, C., Williams, N. \& Klein, A. (2013) Wild Pollinators Enhance Fruit Set of Crops Regardless of Honey Bee Abundance. Science, 339, 1608-1611.

Gill, R.J., Baldock, K.C.R., Brown, M.J.F., Cresswell, J.E., Dicks, L.V., Fountain, M.T., Garratt, M.P.D., Gough, L.A., Heard, M.S., Holland, J.M., Ollerton, J., Stone, G.N., Tang, C.Q., Vanbergen, A.J., Vogler, A.P., Woodward, G., Arce, A.N., Boatman, N.D., Brand-Hardy, R., Breeze, T.D., Green, M., Hartfield, C.M., O’Connor, R.S., Osborne, J.L., Phillips, J., Sutton, P.B. \& Potts, S.G. (2016) Protecting an Ecosystem Service: Approaches to Understanding and Mitigating Threats to Wild Insect Pollinators. Advances in Ecological Research, 54, 135 206.

Grass, I., Albrecht, J., Jauker, F., Diekötter, T., Warzecha, D., Wolters, V. \& Farwig, N. (2016) Much more than bees - Wildflower plantings support highly diverse flower-visitor communities from complex to structurally simple agricultural landscapes. Agriculture, Ecosystems \& Environment, 225, 45-53.

Haslett, J.R. (1989) Interpreting patterns of resource utilization: randomness and selectivity in pollen feeding by adult hoverflies. Oecologia, 78, 433 - 442.

Hawkins, J., de Vere, N., Griffith, A., Ford, C.R., Allainguillaume, J., Hegarty, M.J., Baillie, L. \& Adams-Groom, B. (2015) Using DNA Metabarcoding to Identify the Floral Composition of Honey: A New Tool for Investigating Honey Bee Foraging Preferences. PLoS ONE, 10(8): e0134735. https://doi.org/10.1371/journal.pone.0134735.

Illumina (2013) 16S Metagenomic Sequencing Library Preparation. pp. https://support.illumina.com/content/dam/illumina- 
support/documents/documentation/chemistry_documentation/16s/16smetagenomic-library-prep-guide-15044223-b.pdf.

Inouye, D.W., Larson, B.M.H., Ssymank, A. \& Kevan, P.G. (2015) Flies and Flower III: Ecology of Foraging and Pollination. Journal of Pollination Ecology, 16115-133. Isbell, F., Calcagno, V., Hector, A., Connolly, J., Harpole, W.S., Reich, P.B., SchererLorenzen, M., Schmid, B., Tilman, D., van Ruijven, J., Weigelt, A., Wilsey, B.J., Zavaleta, E.S. \& Loreau, M. (2011) High plant diversity is needed to maintain ecosystem services. Nature, 477, 199-202.

Jaccard, P. (1901) Distribution de la flore alpine dans le bassin des Dranses et dans quelques régions voisines. Bulletin de la Société Vaudoise des Sciences Naturelles, 37, 547 - 579.

Jarlan, A., De Oliveira, D. \& Gingras, J. (1997) Pollination by Eristalis tenax (Diptera : syrphidae) and seed set of greenhouse sweet pepper. Journal of Economic Entomology, 90, 1646-1649.

Kaartinen, R., Stone, G.N., Hearn, J., Lohse, K. \& Roslin, T. (2010) Revealing secret liaisons: DNA barcoding changes our understanding of food webs. Ecological Entomology, 35, 623-638.

Kartzinel, T.R., Chen, P.A., Coverdale, T.C., Erickson, D.L., Kress, W.J., Kuzmina, M.L., Rubenstein, D.I., Wang, W. \& Pringle, R.M. (2015) DNA metabarcoding illuminates dietary niche partitioning by African large herbivores. Proceedings of the National Academy of Sciences, 112, 8019-8024.

King, C., Ballantyne, G. \& Willmer, P. (2013) Why flower visitation is a poor proxy for pollination: measuring single-visit pollen deposition, with implications for pollination networks and conservation. Methods in Ecology and Evolution, 4, 811818.

Klein, A., Vaissière, B.E., Cane, J.H., Steffan-Dewenter, I., Cunningham, S.A., Kremen, C. \& Tscharntke, T. (2007) Importance of pollinators in changing landscapes for world crops. Proceedings of the Royal Society B, 274, 303 - 313.

Larson, B.M.H., Kevan, P.G. \& Inouye, D.W. (2001) Flies and Flowers: the taxonomic diversity of anthophiles and pollinators. Canadian Entomologist, 133, 439 - 465.

Maglianesi, M.A., Bohning-Gaese, K. \& Schleuning, M. (2015) Different foraging preferences of hummingbirds on artificial and natural flowers reveal mechanisms structuring plant-pollinator interactions. Journal of Animal Ecology, 84, 655-664. 
Martinez-Falcon, A.P., Marcos-Garcia, M.A. \& Moreno, C.E. (2011) Temporal shifts and niche overlapping in Copestylum (Diptera, Syrphidae) communities reared in cactus species in a central Mexican scrubland. Ecological Research, 26, 341-350.

Mayer, C., Adler, L., Armbruster, S., Dafni, A., Eardley, C., Huang, S., Kevan, P.G., Ollerton, J., Packer, L., Ssymank, A., Stout, J.C. \& Potts, S.G. (2011) Pollination ecology in the the 21st century: key questions for future research. Journal of Pollination Ecology, 3, 8 - 23.

McLeod, C.R., Yeo, M., Brown, A.E., Burn, A.J., Hopkins, J.J. \& Way, S.F.e. The Habitats Directive: selection of Special Areas of Conservation in the UK . . Joint Nature Conservation Committee, Peterborough.

Memmott, J. (1999) The structure of a plant-pollinator food web. Ecology Letters, 2, 276280.

Morris, R.K.A. (1998) Hoverflies of Surrey. Surrey Wildlife Trust, Woking.

Morse, D.H. (1981) Interactions Among Syrphid Flies and Bumblebees on Flowers. Ecology, 62, 81-88.

Oksanen, J., Guillaume Blanchet, F., Friendly, M., Kindt, R., Legendre, P., McGlinn, D., Minchin, P.R., O'Hara, R.B., Simpson, G.L., Solymos, P., , M., Stevens, H., Szoecs, E. \& Wagner, H. (2013) vegan: Community Ecology Package., pp. Available at CRAN.Rproject. org/package=vegan.

Olesen, J.M. \& Warncke, E. (1989) Predation and Potential Transfer of Pollen in a Population of Saxifraga hirculus. Holarctic Ecology, 12, 87-95.

Ollerton, J., Winfree, R. \& Tarrant, S. (2011) How many flowering plants are pollinated by animals? Oikos, 120, 321-326.

Orford, K.A., Vaughan, I.P. \& Memmott, J. (2015) The forgotten flies: the importance of non-syrphid Diptera as pollinators. Proceedings of the Royal Society B, 282 20142934; DOI: 10.1098/rspb.2014.2934.

Parmenter, L. (1958) Flies (Diptera) and their relationships with plants. Nature, 37, 115 125.

Popic, T.J., Wardle, G.M. \& Davila, Y.C. (2013) Flower-visitor networks only partially predict the function of pollen transport by bees. Austral Ecology, 38, 76-86.

Pornon, A., Escaravage, N., Burrus, M., Holota, H., Khimoun, A., Mariette, J., Pellizzari, C., Iribar, A., Etienne, R., Taberlet, P., Vidal, M., Winterton, P., Zinger, L. \& 
Andalo, C. (2016) Using metabarcoding to reveal and quantify plant-pollinator interactions. Sci Rep, 6, 27282. doi:10.1038/srep27282

Power, E.F., Jackson, Z. \& Stout, J.C. (2016) Organic farming and landscape factors affect abundance and richness of hoverflies (Diptera, Syrphidae) in grasslands. Insect Conservation and Diversity, 9, 244 - 253.

Prodorutti, D. \& Frilli, F. (2008) Entomophilous pollination of raspberry, red currant and highbush blueberry in a mountain area of Friuli-Venezia Giulia (north-eastern Italy). Proceedings of the Ixth International Rubus and Ribes Symposium (eds P. Banados \& A. Dale), pp. 429-434.

R Core Team (2014) R: a language and environment for statistical computing., pp. http://www.R-project.org R Foundation for Statistical Computing, Vienna, Austria.

Rader, R., Bartomeus, I., Garibaldi, L.A., Garratt, M.P.D., Howlett, B.G., Winfree, R., Cunningham, S.A., Mayfield, M.M., Arthur, A.D., Andersson, G.K.S., Bommarco, R., Brittain, C., Carvalheiro, L.G., Chacoff, N.P., Entling, M.H., Foully, B., Freitas, B.M., Gemmill-Herren, B., Ghazoul, J., Griffin, S.R., Gross, C.L., Herbertsson, L., Herzog, F., Hipólito, J., Jaggar, S., Jauker, F., Klein, A.-M., Kleijn, D., Krishnan, S., Lemos, C.Q., Lindström, S.A.M., Mandelik, Y., Monteiro, V.M., Nelson, W., Nilsson, L., Pattemore, D.E., de O. Pereira, N., Pisanty, G., Potts, S.G., Reemer, M., Rundlöf, M., Sheffield, C.S., Scheper, J., Schüepp, C., Smith, H.G., Stanley, D.A., Stout, J.C., Szentgyörgyi, H., Taki, H., Vergara, C.H., Viana, B.F. \& Woyciechowski, M. (2015) Non-bee insects are important contributors to global crop pollination. Proceedings of the National Academy of Sciences, 113, 146 - 151.

Rader, R., Howlett, B.G., Cunningham, S.A., Westcott, D.A., Newstrom-Lloyd, L.E., Walker, M.K., Teulon, D.A.J. \& Edwards, W. (2009) Alternative pollinator taxa are equally efficient but not as effective as the honeybee in a mass flowering crop. Journal of Applied Ecology, 46, 1080-1087.

Radisic, P., Papadopoulos, A., Vujic, A. \& Simic, S. (2001) Pollen feeding of Cheilosia albipila Meigen, 1838 (Diptera: Syrphidae). Acta Entomologica Serbica, 6, 83 92.

Richardson, R.T., Lin, C.-H., Sponsler, D.B., Quijia, J.O., Goodell, K. \& Johnson, R.M. (2015) Application of ITS2 metabarcoding to determine the provenance of pollen 
collected by honey bees in an agroecosystem. Applications in Plant Sciences, $\mathbf{3}$, apps.1400066.

Rodwell, J., Pigott, C.D., Ratclliffe, D.A., Malloch, A.J.C., Proctor, M.C.F., Shimwell, D.W., Huntley, J.P., Radford, E., Wigginton, M.J. \& Wilkins, P. (1991) British Plant Communities Volume 2. Mires and Heaths. Cambridge University Press, Cambridge.

Rollin, O., Benelli, G., Benvenuti, S., Decourtye, A., Wratten, S.D., Canale, A. \& Desneux, N. (2016) Weed-insect pollinator networks as bio-indicators of ecological sustainability in agriculture. A review. Agronomy for Sustainable Development, 36, 1-22.

Scriven, J.J., Whitehorn, P.R., Goulson, D. \& Tinsley, M.C. (2016) Niche partitioning in a sympatric cryptic species complex. Ecology and Evolution, 6, 1328-1339.

Seifan, M., Hoch, E.-M., Hanoteaux, S. \& Tielbörger, K. (2014) The outcome of shared pollination services is affected by the density and spatial pattern of an attractive neighbour. Journal of Ecology, 102, 953-962.

Ssymank, A. (1991) Rüssel- und Körperlängen von Schwebefliegen (Diptera, Syrphidae) unter Berücksichtigung der Verwendung von Alkoholmaterial. Mitteilungen der Schweizerischen Entomologischen Gesellschaft, 64, 67 - 80.

Ssymank, A. \& Gilbert, F. (1993) Anemophilous pollen in the diet of syrphid flies with special reference to the leaf feeding strategy occurring in Xylotini (Diptera: Syrphidae). Deutsche Entomologische Zeitschrift, 40, 245 - 258.

Stace, C. (2010) New Flora of the British Isles. Cambridge University Press, Cambridge. Stanley, D.A., Gunning, D. \& Stout, J.C. (2013) Pollinators and pollination of oilseed rape crops (Brassica napus L.) in Ireland: ecological and economic incentives for pollinator conservation. Journal of Insect Conservation, 17, 1181-1189.

Stevens, D., Smith, S. \& Blackstock, T. (2010) Grasslands of Wales: a Survey of Lowland Species-rich Grasslands 1987 - 2004. University of Wales.

Stubbs, A.E. \& Falk, S.J. (2002) British Hoverflies. An illustrated identification guide. BENHS, Reading.

Sutherland, J.P., Sullivan, M.S. \& Poppy, G.M. (1999) The influence of floral character on the foraging behaviour of the hoverfly, Episyrphus balteatus. Entomologia Experimentalis Et Applicata, 93, 157-164. 
Tomlinson, S. \& Menz, M.H.M. (2015) Does metabolic rate and evaporative water loss reflect differences in migratory strategy in sexually dimorphic hoverflies? Comparative Biochemistry and Physiology a-Molecular \& Integrative Physiology, 190, 61-67.

Valdovinos, F.S., Moisset de Espanés, P., Flores, J.D. \& Ramos-Jiliberto, R. (2013) Adaptive foraging allows the maintenance of biodiversity of pollination networks. Oikos, 122, 907-917.

van der Kooi, C.J., Pen, I., Staal, M., Stavenga, D.G. \& Elzenga, J.T. (2016) Competition for pollinators and intra-communal spectral dissimilarity of flowers. Plant Biology (Stuttg), 18, 56-62.

van Rijn, P.C.J. \& Wäckers, F.L. (2016) Nectar accessibility determines fitness, flower choice and abundance of hoverflies that provide natural pest control. Journal of Applied Ecology, 53, 925 - 933.

Vanbergen, A., Baude, M., Biesmeijer, J., Britton, N., Brown, M., Brown, M., Bryden, J., Budge, G., Bull, J., Carvel, C., Challinor, A., Connolly, C., Evans, D., Feil, E., Garratt, M., Greco, M., Heard, M., Jansen, V., Keeling, M., Kunis, W., Marris, G., Memmott, J., Murray, J., Nicolson, S., Osborne, J., Paxton, R., Pirk, C., Polce, C., Potts, S., Priest, N., Raine, N., Roberts, S., Ryabov, E., Shafir, S., Shirley, M., Simpson, S., Stevenson, P., Stone, G., Termansen, M., Wright, G. \& Initiative, I.P. (2013) Threats to an ecosystem service: pressures on pollinators. Frontiers in Ecology and the Environment, 11, 251-259.

Vanbergen, A.J., Woodcock, B.A., Heard, M.S. \& Chapman, D.S. (2017) Network size, structure and mutualism dependence affect the propensity for plant-pollinator extinction cascades. Functional Ecology, 31: 1285-1293. doi:10.1111/13652435.12823

Venjakob, C., Klein, A.M., Ebeling, A., Tscharntke, T. \& Scherber, C. (2016) Plant diversity increases spatio-temporal niche complementarity in plant-pollinator interactions. Ecology and Evolution 6: 2249-2261. doi:10.1002/ece3.2026

Wardhaugh, C.W. (2015) How many species of arthropods visit flowers? ArthropodPlant Interactions, 9, 547-565.

Wilson, E.E., Sidhu, C.S., LeVan, K.E. \& Holway, D.A. (2010) Pollen foraging behaviour of solitary Hawaiian bees revealed through molecular pollen analysis. Molecular Ecology, 19, 4823-4829. 
Yu, D.W., Ji, Y., Emerson, B.C., Wang, X., Ye, C., Yang, C. \& Ding, Z. (2012)

Biodiversity soup: metabarcoding of arthropods for rapid biodiversity assessment and biomonitoring. Methods in Ecology and Evolution, 3, 613 - 623.

\section{Chapter Seven - DISCUSSION}




\section{Introduction}

This thesis began with an examination of the ecosystem services paradigm as a motivation for the protection of the natural world. Some kind of valuation is intrinsic to the ecosystem service approach, and pollination is readily translated into financial terms (for agricultural production at least) by calculating the difference in the value of crop production (Allsopp, de Lange \& Veldtman 2008). The aim of this thesis was to set pollination, and specifically the role played by hoverflies, in that wider debate around how nature conservation delivers ecosystem services, a debate that requires an evidencebase for informed discussion. A site-based approach has been the focus of nature conservation since the acquisition of the first nature reserves (see Chapter 1). Statutory nature conservation organisations in Britain expend a significant part of their resources on safeguarding and monitoring of individual sites, protected under UK and international law. We need to understand how the ecosystems within these sites are comprised and function, and monitor them effectively, if we are to fully realise their potential to provide ecosystem services.

\section{Hoverflies and Conservation Management - the importance of community integrity}

This study has demonstrated the importance of the hoverfly community as a whole in maintaining the potential pollination service provided by hoverflies. Chapter 2 showed that there were distinctive hoverfly communities, particularly in agriculturally unimproved marshy grasslands, but also in unimproved dry grassland sand agriculturally improved marshy grasslands, where some flower resource is present. This was taken further in Chapter 6, by examining pollen transport networks containing multiple hoverfly genera and species in marshy grasslands. Its key finding was that, whilst pollen loads carried by different species all drew on a core group of about 14 plant taxa, pollen loads differed significantly between hoverfly species.

Some pollination studies have treated hoverflies as a single functional group (Kohler et al. 2008; Barbir et al. 2015; Feltham et al. 2015), especially when they are being compared to other pollinator guilds such as bumblebees or solitary bees. To an extent, this is reasonable; hoverflies will share similarities in feeding behaviour and morphology that will be distinct from those of bees. However, this study has shown that within the hoverfly community, there are likely to be subtle but significant differences in plant 
visitation. Similarly, some studies have focussed on a few easily identified species (frequently Eristalis tenax and Episyrphus balteatus) (Jarlan, De Oliveira \& Gingras 1997; Sutherland, Sullivan \& Poppy 1999; Sarthou et al. 2005). Again, this can be defended, as these species are common, and likely to have a role in pollination in many agricultural systems. There is also considerable value in autecological studies of common and widespread species. Nonetheless, the results from chapter 6 highlight that focussing on a few, easily identified species may underestimate the range of pollination function undertaken by hoverflies. Given the distinctive, species-rich, hoverfly community in marshy grassland, and the complementary pollen loads transported by hoverflies, it is clear that maintaining the integrity of a hoverfly community is essential to retain the full range of potential pollination service hoverflies provide.

Chapter 5 investigated the structure of pollen transport networks of one genus of hoverfly, Eristalis. The structure was generalised at the whole network and species level, but showed some degree of specialisation at the individual level. This supports the results of other studies using observations of flower visitation or palynology, which have also found similar structures in pollination networks in temperate latitudes, and partly explains how generalised networks can still deliver successful pollination for individual plants. The temporal change also shown in chapter 5, with network structure becoming more generalised as the summer flight season progressed, demonstrates the importance of including this aspect in pollination studies (CaraDonna et al. 2017). Pollination networks can change through time on a weekly, seasonal and yearly basis (Alarcón, Waser \& Ollerton 2008; Ponisio, Gaiarsa \& Kremen 2017), yet many pollination studies rely on 'snapshots' over a short time period. Given the effort required to obtain observational data on pollinator behaviour, metabarcoding using reference COI barcode sequences (chapter 4) can offer an enhanced method of data collection for pollination network studies.

These studies on temporal change have implications for the stability of pollination networks. Whilst the role of a particular pollinator species may change over time, the generalised nature of networks may enhance their robustness in the face of environmental change (Nielsen \& Totland 2014). This suggests that pollination networks may be able to withstand disturbance and habitat degradation if a continuity of suitable flower resource can be maintained (Burkle \& Alarcón 2011; Rosa García \& Miñarro 2014). 
However, maintaining the diversity of pollinator guilds will require management that targets all aspects of a species' lifecycle, as described in chapter 2.

These data on pollen transport by different hoverfly species relate back to those in chapter 2, which in part sought to explain hoverfly community composition in different grassland habitats. If individual hoverfly species are carrying distinct pollen loads, then the importance of species-rich hoverfly communities is clear. Other studies have investigated hoverfly diversity in a range of habitats (Haenke et al. 2009; Power, Kelly \& Stout 2012; Wolton et al. 2014). A diverse hoverfly community may appear to be intuitively beneficial from a pollination service perspective, and therefore conserving hoverfly communities can be a justifiable nature conservation aim if ecosystem services are a priority. Chapter 6 gives clear evidence as to how a diverse hoverfly community might provide a more broad-based pollination service. However, the work described in chapter 6 is a limited study of a small proportion of the British hoverfly fauna in one habitat in a short time period. Further work will be required to test whether these pollen load differences extend to other species, habitats, or time frames.

Generalised pollination networks, such as those in this thesis, have implications for plant conservation. Management of sites for rare plant species frequently focuses on creating the desired seral stage for the species in question. However, the requirements of the plant's pollinators, should it be insect pollinated, are rarely considered. The implications of this, in the context of Rubus fruticosus agg., are discussed below.

\section{Factors affecting hoverfly communities}

In conservation management, a factor is an external process affecting the conservation status of a habitat or species in a protected site. Chapter 2 addressed whether the way protected sites are selected in Britain, which is primarily through the extent and quality of particular plant communities, is sufficient to safeguard a pollination service. Although this was a limited study, the result was still unexpected; NVC community could not be used as a proxy for pollinator populations. It was only when the flower resource was considered that the pollinator abundance and species-richness could be predicted. This connection might seem obvious, but flower resource is unlikely to be included in a conservation objective used to monitor a grassland (JNCC 2004) . 'Monitoring', strictly used, refers to a repeated series of measurements that measure whether a desired 
predetermined state is being achieved, or the deviation from that desired state (Hellawell 1991). The aim is to provide a consistent rationale for conservation management, and a trigger for a management response. A conservation objective is a description of the desired state of a site, habitat or feature, and includes both a vision statement (which describes the aim of management) and performance indicators (which are a series of quantifiable measures that specify whether the vision statement is being met). For a grassland, performance indicators are likely to include a requirement for the presence of desirable plant species (Hellawell 1991). However it may not distinguish between a positive indicator species that is flowering, such as Cirsium dissectum, versus one that is not, unless a performance indicator of the number of flowers is specifically included (Hurford 2006). In theory, a grassland SSSI could be in favourable condition (if designated for a plant community), yet offer very little resources to its pollinators.

This result can be set in the context of other studies that look at how low intensity agricultural management can favour pollinators. Some authors have found that managing land organically may have a limited effect on pollinator communities (Brittain et al. 2010; Holland et al. 2015; Hardman et al. 2016). Conversely, others (Andersson et al. 2013; Power, Jackson \& Stout 2016) found that organic farming increased hoverfly abundance and species-richness. Grazing intensity can be a key influence on invertebrate assemblages (Milberg et al. 2016). This study found that wild plant diversity as such did not predict hoverfly or bee abundance and species-richness. Taken together, these studies suggest that a model describing how hoverflies respond to agricultural management should include a number of factors that influence hoverfly populations. These include adult feeding resource (expressed as a density of types of flowers used by hoverflies), the availability of larval habitats, and the impact of wider landscape factors such as habitat connectivity and heterogeneity. Many of these are potentially delivered by organic or 'organic-like' farming. However, agri-environment schemes that have been simplified to reduce the administrative burden may not deliver the desired nature conservation result (Armsworth et al. 2012). Management incentives to encourage hoverfly populations are likely to be detailed and specific, and require a significant monitoring effort (see below) to ensure effective implementation (Dicks et al. 2016; Kovács-Hostyánszki et al. 2017) a combination unlikely to be welcomed by policy makers or farming industry representatives. 
Climate change remains a significant long-term factor affecting pollinator communities. Whilst phenological changes have received some attention, the more direct effects of weather have been largely unstudied. Chapter 3 investigated these direct effects of weather conditions on hoverfly abundance and species-richness. There are numerous anecdotes from naturalists reporting that hoverflies become scarce in cool and wet, and very warm conditions. During periods of high temperatures hoverflies may simply alter their activity to become more active during the cooler times of the day. However, this could have potential impacts on the pollination service provided by hoverflies if warm weather reduces the window in which hoverflies can forage. Diptera are known to be significant pollinators in colder climates (Tiusanen et al. 2016), and any climate warming could have adverse consequences for the pollination service they provide. The effect of such warming on the structure of pollination networks, such as those described in chapters 5 and 6, is also unclear. Pollination networks at higher altitudes have been shown to be particularly vulnerable to climate change (Santamaría et al. 2014). If some hoverfly species retreat northwards, or alter their flight periods, the structure of pollination networks may become modified. Conversely, there is no doubt that the British hoverfly fauna is impoverished compared to that in continental Europe, with nearly three times as many species in northern Europe as in Britain (van Veen 2010). Given the complementary nature of the pollination service by existing hoverfly species described in chapter 6 , the arrival of new species as a result of climate change will have uncertain effects. Considering how little we understand of pollination networks in a range of habitats, there may be insufficient time to study them before these changes take place.

\section{DNA Barcoding as a tool for identification and monitoring}

The importance of hoverfly communities to a potential pollination service shown in chapters 2 and 6 underlines the need for an efficient method of monitoring hoverflies in a range of habitats. Chapter 4 developed a library of COI DNA barcodes for British hoverfly species. Although such sequences have a role in taxonomy (Perez-Banon et al. 2003; Pires \& Marinoni 2010), their purpose here is as a tool for ecological management and monitoring. Safeguarding pollination as an ecosystem service requires an evidence based approach to confirm that our management actions are effective. Monitoring - in the general sense, rather than the more specific definition of Hellawell (1991) - has been 
a feature of ornithology in Britain for many years. Recently, there have been attempts to broaden citizen science with schemes for butterflies (Thomas 2005), plants (Pescott et al. 2015) and, most recently, pollinators (Carvell et al. 2016). How might a library of hoverfly DNA barcodes contribute to this effort?

Citizen scientists can collect samples, but a major impediment is in species identification of the large amounts of material that can be generated (Giangrande 2003). Volunteers can be asked to identify material themselves, but this requires extra work, could deter participation, and may lead to data of dubious quality for taxonomically difficult pollinator species. One option may be to ask volunteers to identify pollinators to broad taxonomic groups ('bumblebee', 'hoverfly') but, as chapter 6 showed, the roles of different hoverfly species in pollination can be complementary. Conserving, and therefore monitoring, species diversity is critical to maintaining the resilience of pollination ecosystem services (Senapathi et al. 2015).

There are four significant drawbacks to the use of DNA barcoding in monitoring. The first is that it cannot give a reliable estimate of abundance, although correction factors for estimating abundance from mixed species samples have been proposed (Thomas et al. 2015). Multiple samples from single locations could help address this, by providing replicates that could then be used to give some relative indication of abundance (Tang et al. 2015). The second is the possibility of biases in the DNA extraction and amplification step. This will improve as new DNA sequencing technologies become available (Creer $e t$ al. 2016), but can also be alleviated by the relatively prosaic precaution of sorting invertebrates into size categories prior to DNA extraction (Elbrecht, Peinert \& Leese 2017). The third is that discrimination between some species groups is poor, as was the case in this study with two genera in particular, Eupeodes and Sphaerophoria. The final drawback is the cost of sequencing. This will undoubtedly reduce as the technology matures, but in any event has to be set against the cost, time and difficulty of identifying samples using morphology. However, despite these shortcomings, DNA barcoding has already been successfully applied to mixed species invertebrate samples collected using Malaise and pan traps as part of monitoring programmes (Yu et al. 2012), including as part of citizen science projects (Geiger et al. 2016; Moriniere et al. 2016), and is ready to be used in pollinator monitoring studies. The future role of DNA barcoding in monitoring hoverfly communities is explored below. 


\section{Future Research Directions}

In addition to the habitat requirements of hoverflies, impacts of weather and further work on the detailed nature of hoverfly pollen transport networks, there are other research directions that are prompted by this study.

\section{Monitoring hoverflies in agricultural situations}

Given their wide range of larval habitats, and importance in the delivery of a pollination service, monitoring hoverflies is an attractive option as a method of evaluating the condition of an ecosystem and its services. The varied larval habitat traits of hoverflies have been shown to be important in interpreting changes in climate and land use (Aguirre-Gutiérrez et al. 2016). A similar argument has been made for using the decline in populations of bees as indicators of wider ecological damage (Goulson \& Nicholls 2016). Hoverfly assemblages have been suggested both as a monitoring tool and a means to select areas of conservation designation (Sommaggio 1999; Vujić et al. 2016).

Using hoverfly assemblages for monitoring would present two issues. The first would be the difficulty of defining a required condition for a hoverfly assemblage, both at a site and at a national level. This is not unusual. Site managers frequently find it difficult to define such limits, to answer the 'what does favourable condition look like?' question (Hurford 2006). The second would be selecting species that are informative in a monitoring sense, particularly if the responses of pollinator assemblages to environmental change are unpredictable (Bartomeus et al. 2017). Monitoring all species may not be practical (but see below), and therefore species have to be carefully selected, both to inform monitoring about the species itself and also to provide some information about wider assemblage condition.

A list of candidate pollinator species for monitoring has been suggested by Carvell et al. (2016), selected because they are widespread and abundant in a range of habitats, or visitors to crops. This included 16 species of hoverfly (see table 1), all of which could be readily detected using pan trapping. 
Table 10 A list of candidate hoverfly species for monitoring as part of a wider UK pollinator monitoring scheme. Adapted from Carvell et al. (2016). 'Ease of Identification' from 1 (easy) to 3 (difficult). The most abundant visitors to four key UK crops and indicated by ' $Y$ '.

\begin{tabular}{|l|c|c|l|}
\hline \multicolumn{1}{|c|}{ Species } & $\begin{array}{c}\text { Ease of } \\
\text { Identification }\end{array}$ & $\begin{array}{c}\text { Flight } \\
\text { Season }\end{array}$ & $\begin{array}{l}\text { Crop } \\
\text { Visitor }\end{array}$ \\
\hline Episyrphus balteatus & 1 & Jan - Dec & \\
\hline Eristalis abusivus & 3 & Mar - Oct & \\
\hline Eristalis arbustorum & 2 & Apr - Nov & \\
\hline Eristalis pertinax & 2 & Mar - Nov & \\
\hline Eristalis tenax & 1 & Jan - Dec & \\
\hline Eupeodes corollae & 1 & Mar - Nov & \\
\hline Helophilus hybridus & 2 & Apr - Oct & \\
\hline Helophilus pendulus & 2 & Apr - Nov & Y \\
\hline Melanostoma mellinum & 2 & Apr - Oct & Y \\
\hline Melanostoma scalare & 2 & Apr - Nov & Y \\
\hline Neoascia podagrica & 3 & Apr - Nov & \\
\hline Platycheirus albimanus & 2 & Mar - Nov & Y \\
\hline Platycheirus granditarsus & 1 & May - Oct & \\
\hline Platycheirus manicatus & 2 & Apr - Nov & Y \\
\hline Rhingia campestris & 1 & Apr - Oct & \\
\hline Sericomyia silentis & 1 & May - Nov & \\
\hline Syrphus ribesii & 3 & Mar - Nov & \\
\hline
\end{tabular}

This list could be used to develop a list of indicator species to evaluate the speciesrichness of a wider hoverfly community. Hegland et al. (2010) showed that between 70 and $85 \%$ of functionally important species could be recorded by sampling at what they termed 'peak season'. From the data in this thesis, the number of species present in one sampling interval in late August appears to be positively correlated with both total abundance and species-richness from June to August (author unpublished data). 
One major obstacle to the collection of pollinator monitoring data on a large scale would be insufficient specialists to identify species from the large numbers of samples that would be generated, as described above. With the increasing availability of libraries of pollinator DNA barcode sequences, such as that created in this study, using barcoding as part of monitoring protocols is becoming increasingly practical.

\section{How variation in pollen deposition influences plant reproduction}

This study has shown the relative proportions, in semi-quantitative terms, of pollen of various plant taxonomic groups hoverflies are transporting (chapters 5 and 6). This gives an indication of the role of hoverflies in the pollination function in marshy grasslands, but questions remain to be addressed. Plant reproductive success has been shown to be linked to the amount of pollen deposited on stigmas in a variety of plant taxa ('pollen limitation') (Knight et al. 2005). Seed set follows a curve that rises to an asymptote, beyond which seed set is limited by factors other than pollen availability, such as the accessibility of resources for seed production and the trade off in resources devoted to high pollen production (Haig \& Westoby 1988). This limitation has been observed in plants in the field (Campbell \& Bischoff 2013; Lázaro, Lundgren \& Totland 2015). The phenomenon could be a result of limits in the pollination service, but could also be a result of a 'bet hedging' (Ashman et al. 2004) strategy by plants, whereby the ability to increase seed set when pollen deposition is increased is retained to take advantage of rare situations where an exceptional amount of pollen becomes available (Knight et al. 2005) .

Pollinator studies are starting to move beyond pollen transport to look at how successful pollinator visitation is in pollen deposition and fertilisation (King, Ballantyne \& Willmer 2013; Ballantyne et al. 2017). However, this is still some way from answering the fundamental question for plant reproduction - for pollinator visitation and pollen loads, how much is enough? We might assume that increasing the number of pollen grains deposited on a stigma should increase plant reproductive success, given the observations of pollen limitation. However, evidence is limited, and resolving the relationship between pollinator visitation, pollen load, transport, deposition, and fertilisation remains a key question in pollination research. Molecular techniques that could accurately estimate pollen loads (rather than give an indication of relative frequency) would be a significant step forward in answering this question. 
The role of Rubus fruticosus agg. and Succisa pratensis in the functioning of pollination networks

This study has shown that Rubus fruticosus agg. is a critical species for feeding by adult hoverflies, if the number of Rubus pollen DNA sequences retrieved from pollen carried by hoverflies is used as a proxy for the frequency with which the plant's flowers are visited. However, the complexity of $R$. fruticosus agg. biology means there is still much to learn about the significance of this species for pollinators. Rubus fruticosus agg. is facultatively apomictic; seed is formed asexually by the plant, but requires fertilisation to produce the endosperm (pseudogamy). There are approximately 320 microspecies within the Rubus fruticosus species complex in Britain, some of which are widespread, but others having specific ecological requirements (Taylor 2005). There are 22 microspecies associated with the south Wales florula, a number of which are endemic to the area (Newton \& Randall 2004). This range of microspecies has a variety of reproductive strategies, including pseudogamy, self- and cross-pollination, and vegetative reproduction (Nybom 1987; Kollmann, Steinger \& Roy 2000) with the species able to set fruit in some situations in the absence of insect pollinators (Jacobs et al. 2009). R. fruticosus can also potentially flower from May to September, providing a consistent nectar resource throughout most hoverfly species flight periods (Baude et al. 2016) (see below). Its taxonomic diversity, range of habitats and continuity of nectar resource makes the plant an important forage species for short-tongued bumblebees and honey bees (Fussell \& Corbet 1991), and satyrid butterflies (Dover 1996), as well as hoverflies.

However, significant questions remain. How are $R$. fruticosus microspecies diversity and abundance related to pollinator abundance - is one more important than the other? What role do insects have in the reproduction of various microspecies? Although attempts have been made to emphasise the importance of scrub, of which $R$. fruticosus is often a significant component (Day, Symes \& Robertson 2003), it is frequently seen as a problem to be removed in both agricultural and nature conservation settings. However, its role in providing a consistent and high-quality food resource (see below) to pollinator populations in adjacent habitats should not be underestimated. DNA sequencing will have an important role to play in answering questions about the ecological importance of the taxonomic variety of Rubus, once consistent genetic loci have been identified that can differentiate microspecies within the $R$. fruticosus species complex. 
Rubus fruticosus agg. and Succisa pratensis pollen were both a significant part of the pollen loads of hoverflies in this study, yet the species provide quite contrasting resources for pollinators. Using data from Baude et al. (2016), R. fruticosus has the second highest nectar sugar content (1892 ug/flower/day) of any plant species present on the field sites in this study, the highest being Iris pseudacorus (3412 ug/flower/day). Of the ten top species for nectar sugar content, only $R$. fruticosus and Silene dioica (relatively rare on field sites in this study) have radially symmetrical flowers readily accessible to the majority of hoverflies. The remainder (e.g Iris pseudacorus, Lonicera periclymenum, Digitalis purpurea, and Lathyrus pratensis) all have deep flowers, or flowers with bilateral symmetry that cannot be readily accessed by hoverflies (Gilbert 1981). In addition, $R$. fruticosus nectar has a range of sugars whose attractiveness to pollinators has long being recognised (Wykes 1952). The value of $R$. fruticosus agg. flowers to hoverflies is therefore easily explained.

However, of the species for which data is available in Baude et al. (Baude et al. 2016), 70 were present on field sites in this study. Succisa pratensis ranked 31 (47 ug/flower/day). Given its relatively modest nectar production, why is hoverfly visitation to $S$. pratensis so high? S. pratensis 'flowers' are actually composed of many individual florets, in which the male stamen is held close to the flower, whilst the female stigma is held on a long style that projects above the flower. It is possible that the number of S. pratensis flowers in late summer in marshy grasslands, together with their colour (blue, at a time when there are few other blue flowers present) may make them a reliable and easily recognised food source. Alternatively, S. pratensis nectar or pollen may have particular components that make it an especially valuable food source. As $S$. pratensis is present in a number of plant communities of conservation interest (e.g. NVC communities M22, M24, M25, MG5c and U4c), these are further questions that further research could address.

Compared to many British invertebrate taxa, hoverflies are relatively well known. There are guides that make identification relatively straightforward, with care, for the majority of British species. Yet this study has shown that there is still much to learn about how they respond to habitat management and climate, what role DNA barcoding can play in their identification, and the structure of their pollination networks. Hoverflies contribute 
to a valuable pollination ecosystem service that supports a range of crops, and natural ecosystems, both in Britain and elsewhere in the world. Beyond that, they are also beautiful insects with a bewildering range of mimicry and larval ecology. More discoveries wait to be made, particularly as new analytical tools become available, about these remarkable insects.

\section{References}

Aguirre-Gutiérrez, J., Kissling, W.D., Carvalheiro, L.G., WallisDeVries, M.F., Franzén, M. \& Biesmeijer, J.C. (2016) Functional traits help to explain half-century long shifts in pollinator distributions. Scientific Reports, 6, 24451 doi:10.1038/srep24451

Alarcón, R., Waser, N.M. \& Ollerton, J. (2008) Year-to-year variation in the topology of a plant-pollinator interaction network. Oikos, 117, 1796-1807.

Allsopp, M.H., de Lange, W.J. \& Veldtman, R. (2008) Valuing insect pollination services with cost of replacement. PLoS ONE, 3(9): e3128. https://doi.org/10.1371/journal.pone.0003128

Andersson, G.K.S., Birkhofer, K., Rundlof, M. \& Smith, H.G. (2013) Landscape heterogeneity and farming practice alter the species composition and taxonomic breadth of pollinator communities. Basic and Applied Ecology, 14, 540-546.

Armsworth, P.R., Acs, S., Dallimer, M., Gaston, K.J., Hanley, N. \& Wilson, P. (2012) The cost of policy simplification in conservation incentive programs. Ecology Letters, 15, 406-414.

Ashman, T.-L., Knight, T.M., Steets, J.A., Amarasekare, P., Burd, M., Campbell, D.R., Dudash, M.R., Johnston, M.O., Mazer, S.J., Mitchell, R.J., Morgan, M.T. \& Wilson, W.G. (2004) Pollen limitation of plant reproduction: ecological and evolutionary causes and consequences. Ecology, 85, 2408-2421.

Ballantyne, G., Baldock, K.C.R., Rendell, L. \& Willmer, P.G. (2017) Pollinator importance networks illustrate the crucial value of bees in a highly speciose plant community. Scientific Reports, 7, 8389. doi:10.1038/s41598-017-08798-x

Barbir, J., Badenes-Pérez, F.R., Fernández-Quintanilla, C. \& Dorado, J. (2015) The attractiveness of flowering herbaceous plants to bees (Hymenoptera: Apoidea) and 
hoverflies (Diptera: Syrphidae) in agro-ecosystems of Central Spain. Agricultural and Forest Entomology, 17, 20-28.

Bartomeus, I., Cariveau, D.P., Harrison, T. \& Winfree, R. (2017) On the inconsistency of pollinator species traits for predicting either response to land-use change or functional contribution. Oikos, doi:10.1111/oik.04507

Baude, M., Kunin, W.E., Boatman, N.D., Conyers, S., Davies, N., Gillespie, M.A.K., Morton, R.D., Smart, S.M. \& Memmott, J. (2016) Historical nectar assessment reveals the fall and rise of floral resources in Britain. Nature, 530, 85-88.

Brittain, C., Bommarco, R., Vighi, M., Settele, J. \& Potts, S.G. (2010) Organic farming in isolated landscapes does not benefit flower-visiting insects and pollination. Biological Conservation, 143, 1860-1867.

Burkle, L.A. \& Alarcón, R. (2011) The future of plant-pollinator diversity: Understanding interaction networks acrosss time, space, and global change. American Journal of Botany, 98, 528-538.

Campbell, D.R. \& Bischoff, M. (2013) Selection for a floral trait is not mediated by pollen receipt even though seed set in the population is pollen-limited. Functional Ecology, 27, 1117-1125.

CaraDonna, P.J., Petry, W.K., Brennan, R.M., Cunningham, J.L., Bronstein, J.L., Waser, N.M. \& Sanders, N.J. (2017) Interaction rewiring and the rapid turnover of plantpollinator networks. Ecology Letters, 20: 385-394. doi:10.1111/ele.12740 n/a-n/a.

Carvell, C., Isaac, N.J.B., Jitlal, M., Peyton, J., Powney, G.D., Roy, D.B., Vanbergen, A.J., O’Connor, R.S., Jones, C.M., Kunin, W.E., Breeze, T.D., Garratt, M.P.D., Potts, S.G., Harvey, M., Ansine, J., Comont, R.F., Lee, P., Edwards, M., Roberts, S.P.M., Morris, R.K.A., Musgrove, A.J., Brereton, T., Hawes, C. \& Roy, H.E. (2016) Design and Testing of a National Pollinator and Pollination Monitoring Framework. Final summary report to the Department for Environment, Food and Rural Affairs (Defra), Scottish Government and Welsh Government: Project WC1101.

Creer, S., Deiner, K., Frey, S., Porazinska, D., Taberlet, P., Thomas, W.K., Potter, C. \& Bik, H.M. (2016) The ecologist's field guide to sequence-based identification of biodiversity. Methods in Ecology and Evolution, 7, 1008 - 1018. 
Day, J., Symes, N. \& Robertson, P. (2003) The Scrub Management Handbook: Guidance on themanagement of scrub on nature conservation sites. The Forum for the Application of Conservation Techniques/English Nature.

Dicks, L.V., Viana, B., Bommarco, R., Brosi, B., Arizmendi, M.d.C., Cunningham, S.A., Galetto, L., Hill, R., Lopes, A.V., Pires, C., Taki, H. \& Potts, S.G. (2016) Ten policies for pollinators. Science, 354, 975-976 DOI: 10.1126/science.aai9226

Dover, J.W. (1996) Factors affecting the distribution of satyrid butterflies on arable farmland. Journal of Applied Ecology, 33, 723-734.

Elbrecht, V., Peinert, B. \& Leese, F. (2017) Sorting things out: Assessing effects of unequal specimen biomass on DNA metabarcoding. Ecology and Evolution, 7:6918-6926. https://doi.org/10.1002/ece3.3192

Feltham, H., Park, K., Minderman, J. \& Goulson, D. (2015) Experimental evidence that wildflower strips increase pollinator visits to crops. Ecology and Evolution, 5, 3523-3530.

Fussell, M. \& Corbet, S.A. (1991) Forage for bumblebees and honey-bees in farmland - a case-study. Journal of Apicultural Research, 30, 87-97.

Geiger, M.F., Moriniere, J., Hausmann, A., Haszprunar, G., Wägele, W., Hebert, P.D.N. \& Rulik, B. (2016) Testing the Global Malaise Trap Program - How well does the current barcode reference library identify flying insects in Germany? Biodiversity Data Journal, (4): e10671 doi: 10.3897/BDJ.4.e10671

Giangrande, A. (2003) Biodiversity, conservation, and the 'Taxonomic impediment'. Aquatic Conservation-Marine and Freshwater Ecosystems, 13, 451-459.

Gilbert, F.S. (1981) Foraging ecology of hoverflies: morphology of the mouthparts in relation to feeding on nectar and pollen in some common urban species. Ecological Entomology 6, 245 - 262

Goulson, D. \& Nicholls, E. (2016) The canary in the coalmine; bee declines as an indicator of environmental health. Science Progress, 99, 312-326.

Haenke, S., Scheid, B., Schaefer, M., Tscharntke, T. \& Thies, C. (2009) Increasing syrphid fly diversity and density in sown flower strips within simple vs. complex landscapes. Journal of Applied Ecology, 46, 1106-1114.

Haig, D. \& Westoby, M. (1988) On limits to seed production. American Naturalist, 131, 757-759. 
Hardman, C.J., Harrison, D.P., Shaw, P.J., Nevard, T.D., Hughes, B., Potts, S.G. \& Norris, K. (2016) Supporting local diversity of habitats and species on farmland: a comparison of three wildlife-friendly schemes. Journal of Applied Ecology, 53, 171-180.

Hegland, S.J., Dunne, J., Nielsen, A. \& Memmott, J. (2010) How to monitor ecological communities cost-efficiently: The example of plant-pollinator networks.

Biological Conservation, 143, 2092-2101.

Hellawell, J.M. (1991) Development of a rationale for monitoring. Monitoring for Conservation and Ecology (ed. B. Goldsmith). Chapman and Hall, London.

Holland, J.M., Smith, B.M., Storkey, J., Lutman, P.J.W. \& Aebischer, N.J. (2015) Managing habitats on English farmland for insect pollinator conservation. Biological Conservation, 182, 215-222.

Hurford, C. (2006) Monitoring in Cultural Habitats. Monitoring Nature Conservation in Cultural Habitats: A practical Guide and Case Studies (eds C. Hurford \& M. Schneider). Springer, Dordrecht.

Jacobs, J.H., Clark, S.J., Denholm, I., Goulson, D., Stoate, C. \& Osborne, J.L. (2009) Pollination biology of fruit-bearing hedgerow plants and the role of flowervisiting insects in fruit-set. Annals of Botany, 104, 1397-1404.

Jarlan, A., De Oliveira, D. \& Gingras, J. (1997) Pollination by Eristalis tenax (Diptera : syrphidae) and seed set of greenhouse sweet pepper. Journal of Economic Entomology, 90, 1646-1649.

JNCC (2004) Common Standards Monitoring Guidance for Lowland Grassland Habitats. Peterborough.

King, C., Ballantyne, G. \& Willmer, P. (2013) Why flower visitation is a poor proxy for pollination: measuring single-visit pollen deposition, with implications for pollination networks and conservation. Methods in Ecology and Evolution, 4, 811818.

Knight, T.M., Steets, J.A., Vamosi, J.C., Mazer, S.J., Burd, M., Campbell, D.R., Dudash, M.R., Johnston, M.O., Mitchell, R.J. \& Ashman, T.L. (2005) Pollen limitation of plant reproduction: Pattern and process. Annual Review of Ecology Evolution and Systematics, 36, 467-497. 
Kohler, F., Verhulst, J., van Klink, R. \& Kleijn, D. (2008) At what spatial scale do highquality habitats enhance the diversity of forbs and pollinators in intensively farmed landscapes? Journal of Applied Ecology, 45, 753-762.

Kollmann, J., Steinger, T. \& Roy, B.A. (2000) Evidence of sexuality in European Rubus (Rosaceae) species based on AFLP and allozyme analysis. American Journal of Botany, 87, 1592-1598.

Kovács-Hostyánszki, A., Espíndola, A., Vanbergen, A.J., Settele, J., Kremen, C. \& Dicks, L.V. (2017) Ecological intensification to mitigate impacts of conventional intensive land use on pollinators and pollination. Ecology Letters, 20: 673-689. doi:10.1111/ele.12762

Lázaro, A., Lundgren, R. \& Totland, Ø. (2015) Pollen limitation, species’ floral traits and pollinator visitation: different relationships in contrasting communities. Oikos, 124, 174-186.

Milberg, P., Bergman, K.-O., Cronvall, E., Eriksson, Å.I., Glimskär, A., Islamovic, A., Jonason, D., Löfqvist, Z. \& Westerberg, L. (2016) Flower abundance and vegetation height as predictors for nectar-feeding insect occurrence in Swedish semi-natural grasslands. Agriculture, Ecosystems \& Environment, 230, 47-54.

Moriniere, J., de Araujo, B.C., Lam, A.W., Hausmann, A., Balke, M., Schmidt, S., Hendrich, L., Doczkal, D., Fartmann, B., Arvidsson, S. \& Haszprunar, G. (2016) Species Identification in Malaise Trap Samples by DNA Barcoding Based on NGS Technologies and a Scoring Matrix. Plos One, 11(5): e0155497. https://doi.org/10.1371/journal.pone.0155497

Newton, A. \& Randall, R.D. (2004) Atlas of British and Irish Brambles. Botanical Society of the British Isles, London.

Nielsen, A. \& Totland, Ø. (2014) Structural properties of mutualistic networks withstand habitat degradation while species functional roles might change. Oikos, 123, 323333.

Nybom, H. (1987) Pollen-limited seed set in pseudogamous blackberries (Rubus L. subgen. Rubus). Oecologia, 72, 562-568.

Perez-Banon, C., Rojo, S., Stahls, G. \& Marcos-Garcia, M. (2003) Taxonomy of European Eristalinus (Diptera: Syrphidae) based on larval morphology and molecular data. European Journal of Entomology, 100, 417-428. 
Pescott, O.L., Walker, K.J., Pocock, M.J.O., Jitlal, M., Outhwaite, C.L., Cheffings, C.M., Harris, F. \& Roy, D.B. (2015) Ecological monitoring with citizen science: the design and implementation of schemes for recording plants in Britain and Ireland. Biological Journal of the Linnean Society, 115, 505-521.

Pires, A.C. \& Marinoni, L. (2010) DNA barcoding and traditional taxonomy unified through Integrative Taxonomy: a view that challenges the debate questioning both methodologies. Biota Neotropica, 10, 339-346.

Ponisio, L.C., Gaiarsa, M.P. \& Kremen, C. (2017) Opportunistic attachment assembles plant-pollinator networks. Ecology Letters, 20, 1261-1272.

Power, E.F., Jackson, Z. \& Stout, J.C. (2016) Organic farming and landscape factors affect abundance and richness of hoverflies (Diptera, Syrphidae) in grasslands. Insect Conservation and Diversity, 9, 244 - 253.

Power, E.F., Kelly, D.L. \& Stout, J.C. (2012) Organic Farming and Landscape Structure: Effects on Insect-Pollinated Plant Diversity in Intensively Managed Grasslands. Plos One, 7(5): e38073. https://doi.org/10.1371/journal.pone.0038073

Rosa García, R. \& Miñarro, M. (2014) Role of floral resources in the conservation of pollinator communities in cider-apple orchards. Agriculture, Ecosystems and Environment, 183, 118-126.

Santamaría, S., Galeano, J., Pastort, J.M. \& Méndez, M. (2014) Robustness of alpine pollination networks: Effects of network structure and consequences for endemic plants. Arctic, Antarctic, and Alpine Research, 46, 568-580.

Sarthou, J.P., Ouin, A., Arrignon, F., Barreau, G. \& Bouyjou, B. (2005) Landscape parameters explain the distribution and abundance of Episyrphus balteatus (Diptera : Syrphidae). European Journal of Entomology, 102, 539-545.

Senapathi, D., Biesmeijer, J.C., Breeze, T.D., Kleijn, D., Potts, S.G. \& Carvalheiro, L.G. (2015) Pollinator conservation - the difference between managing for pollination services and preserving pollinator diversity. Current Opinion in Insect Science, 12, 93-101.

Sommaggio, D. (1999) Syrphidae: can they be used as environmental bioindicators? Agriculture Ecosystems \& Environment, 74, 343-356.

Sutherland, J.P., Sullivan, M.S. \& Poppy, G.M. (1999) The influence of floral character on the foraging behaviour of the hoverfly, Episyrphus balteatus. Entomologia Experimentalis Et Applicata, 93, 157-164. 
Tang, M., Hardman, C.J., Ji, Y., Meng, G., Liu, S., Tan, M., Yang, S., Moss, E.D., Wang, J., Yang, C., Bruce, C., Nevard, T., Potts, S.G., Zhou, X. \& Yu, D.W. (2015) High-throughput monitoring of wild bee diversity and abundance via mitogenomics. Methods in Ecology and Evolution 6: 1034-1043. doi:10.1111/2041-210X.12416

Taylor, K. (2005) Biological Flora of the British Isles: Rubus vestitus Weihe. Journal of Ecology, 93, 1249-1262.

Thomas, A.C., Deagle, B.E., Paige Eveson, J., Harsch, C.H. \& Trites, A.W. (2015) Quantitative DNA metabarcoding: improved estimates of species proportional biomass using correction factors derived from control material. Molecular Ecology Resources, 16: 714-726. doi:10.1111/1755-0998.12490.

Thomas, J.A. (2005) Monitoring change in the abundance and distribution of insects using butterflies and other indicator groups. Philosophical Transactions of the Royal Society B-Biological Sciences, 360, 339-357.

Tiusanen, M., Hebert, P.D., Schmidt, N.M. \& Roslin, T. (2016) One fly to rule them allmuscid flies are the key pollinators in the Arctic. Proceeding of the Royal Society B, 283 20161271; DOI: 10.1098/rspb.2016.1271.

van Veen, M.P. (2010) Hoverflies of Northwest Europe: Identification Keys to the Syrphidae KNNV Uitgeverij, Zeist.

Vujić, A., Radenković, S., Nikolić, T., Radišić, D., Trifunov, S., Andrić, A., Markov, Z., Jovičić, S., Stojnić, S.M., Janković, M. \& Lugonja, P. (2016) Prime Hoverfly (Insecta: Diptera: Syrphidae) Areas (PHA) as a conservation tool in Serbia. Biological Conservation, 198, 22-32.

Wolton, R.J., Bentley, H., Chandler, P.J., Drake, C.M., Kramer, J., Plant, A.R. \& Stubbs, A.E. (2014) The diversity of Diptera associated with a British hedge. Dipterists Digest, 21, 1 - 36.

Wykes, G.R. (1952) An investigation of the sugars present in in the nectar of flowers of various species. New Phytologist, 51, 210-215.

Yu, D.W., Ji, Y., Emerson, B.C., Wang, X., Ye, C., Yang, C. \& Ding, Z. (2012) Biodiversity soup: metabarcoding of arthropods for rapid biodiversity assessment and biomonitoring. Methods in Ecology and Evolution, 3, 613 - 623. 


\section{Appendices}

Selected appendices are included here. Complete appendices for all chapters are available via doi: $10.6084 / \mathrm{m} 9$. figshare.6210311 
Chapter 2 Appendix 1. Grassland sites details and sampling dates.

\begin{tabular}{|l|c|c|c|l|l|l}
\hline Site Name & Altitude (m) & $\begin{array}{l}\text { Field Area } \\
\text { (ha) }\end{array}$ & $\begin{array}{l}\text { GB Grid } \\
\text { Reference }\end{array}$ & $\begin{array}{l}\text { Sample Date } \\
\mathbf{1}\end{array}$ & $\begin{array}{l}\text { Sample Date } \\
\mathbf{2}\end{array}$ & $\begin{array}{l}\text { Sample D } \\
\mathbf{3}\end{array}$ \\
\hline DG1 & 144 & 1 & SN 627305 & $24 / 06 / 2011$ & $08 / 07 / 2011$ & $22 / 07 / 2$ \\
\hline DG2 & 145 & 2 & SN 676318 & $24 / 06 / 2011$ & $08 / 07 / 2011$ & $22 / 07 / 2$ \\
\hline DG3 & 127 & 2.3 & SN 656302 & $17 / 06 / 2011$ & $08 / 07 / 2011$ & $22 / 07 / 2$ \\
\hline DG4 & 195 & 1.2 & SN 720117 & $17 / 06 / 2011$ & $01 / 07 / 2011$ & $15 / 07 / 2$ \\
\hline DG5 & 216 & 1.7 & SN 587160 & $17 / 06 / 2011$ & $01 / 07 / 2011$ & $15 / 07 / 2$ \\
\hline IDG 1 & 135 & 2.5 & SN642188 & $24 / 06 / 2011$ & $08 / 07 / 2011$ & $22 / 07 / 2$ \\
\hline IDG2 & 112 & 1.3 & SN 671280 & $24 / 06 / 2011$ & $08 / 07 / 2011$ & $22 / 07 / 2$ \\
\hline IDG3 & 72 & 6.9 & SN 527175 & $17 / 06 / 2011$ & $01 / 07 / 2011$ & $15 / 07 / 2$ \\
\hline IDG4 & 80 & 4.5 & SN 533185 & $17 / 06 / 2011$ & $01 / 07 / 2011$ & $15 / 07 / 2$ \\
\hline IDG5 & 34 & 1.5 & SN 6372222 & $17 / 06 / 2011$ & $01 / 07 / 2011$ & $15 / 07 / 2$ \\
\hline IMG1 & 207 & 2.8 & SN 685073 & $24 / 06 / 2011$ & $08 / 07 / 2011$ & $22 / 07 / 2$ \\
\hline IMG2 & 208 & 1.3 & SN 668215 & $24 / 06 / 2011$ & $08 / 07 / 2011$ & $22 / 07 / 2$ \\
\hline IMG3 & 84 & 2.4 & SN 498156 & $17 / 06 / 2011$ & $01 / 07 / 2011$ & $15 / 07 / 2$ \\
\hline IMG4 & 60 & 0.6 & SN 519164 & $17 / 06 / 2011$ & $01 / 07 / 2011$ & $15 / 07 / 2$ \\
\hline IMG5 & 173 & 2.3 & SN720138 & $17 / 06 / 2011$ & $01 / 07 / 2011$ & $15 / 07 / 2$ \\
\hline MG1 & 209 & 0.4 & SN 711213 & $24 / 06 / 2011$ & $08 / 07 / 2011$ & $22 / 07 / 2$ \\
\hline MG2 & 84 & 1.2 & SN 681283 & $24 / 06 / 2011$ & $08 / 07 / 2011$ & $22 / 07 / 2$ \\
\hline MG3 & 186 & 0.8 & SN 744226 & $24 / 06 / 2011$ & $08 / 07 / 2011$ & $22 / 07 / 2$ \\
\hline MG4 & 170 & 3.7 & SN 683240 & $17 / 06 / 2011$ & $01 / 07 / 2011$ & $15 / 07 / 2$ \\
\hline MG5 & 193 & 2.8 & SN 650205 & $17 / 06 / 2011$ & $01 / 07 / 2011$ & $15 / 07 / 2$ \\
\hline & & & & & & \\
\hline
\end{tabular}

Chapter 2 Appendix 4. Hoverfly species recorded at 20 grassland sites in west Wales June - August 


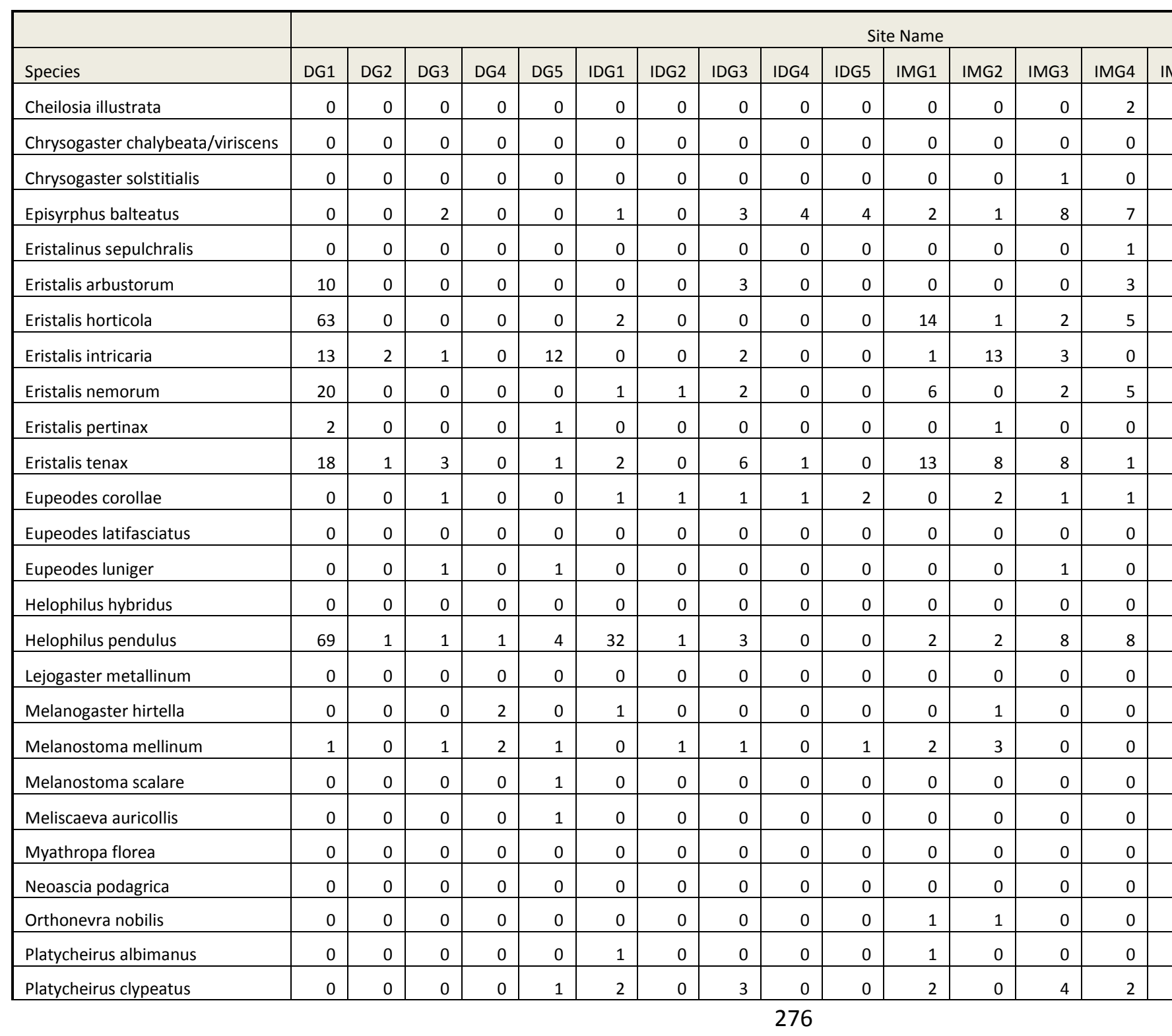




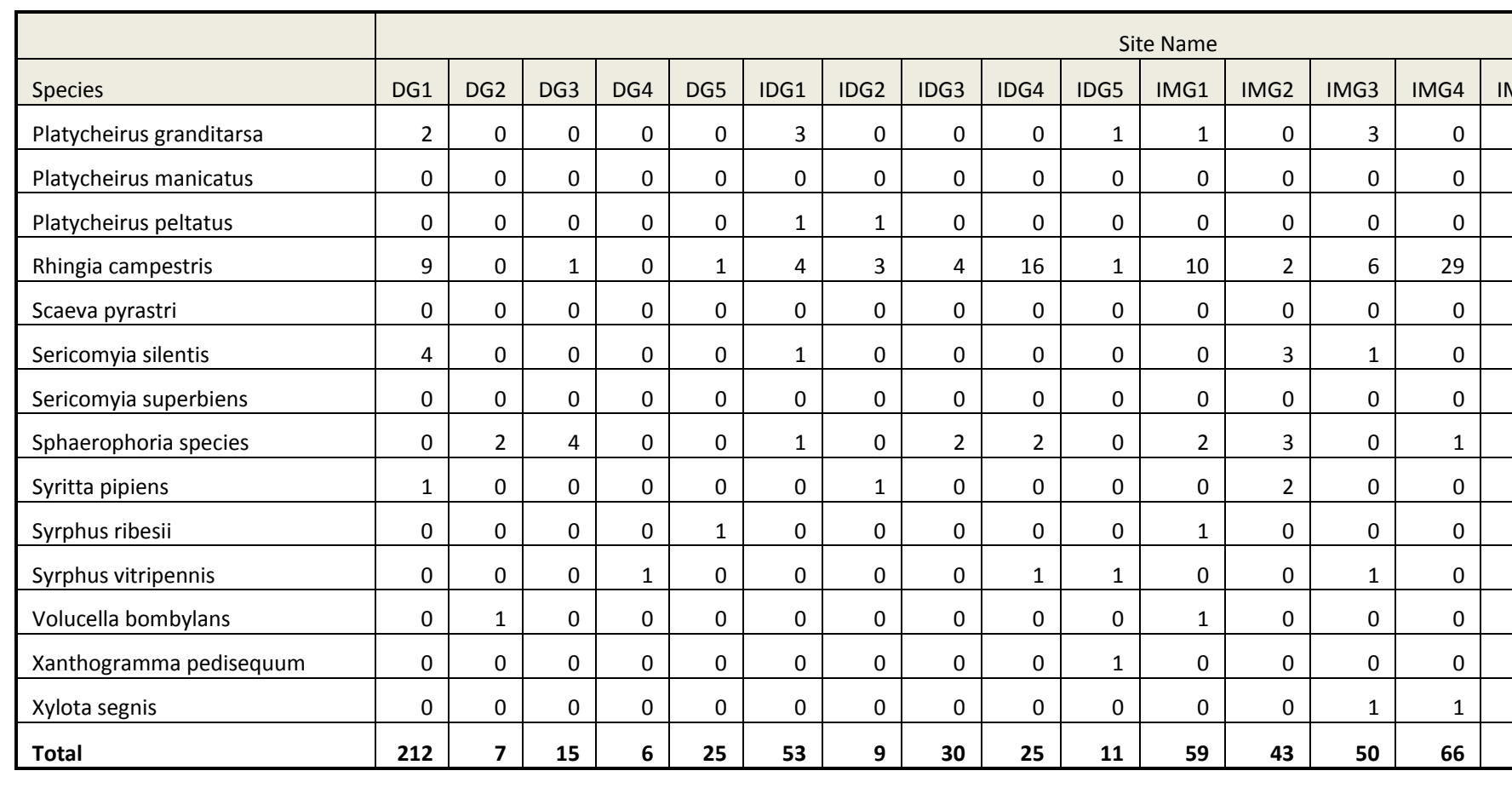


Chapter 4 Appendix 5 Countries of origin and numbers of specimens for hoverfly specimens used i mutabilis agg.)

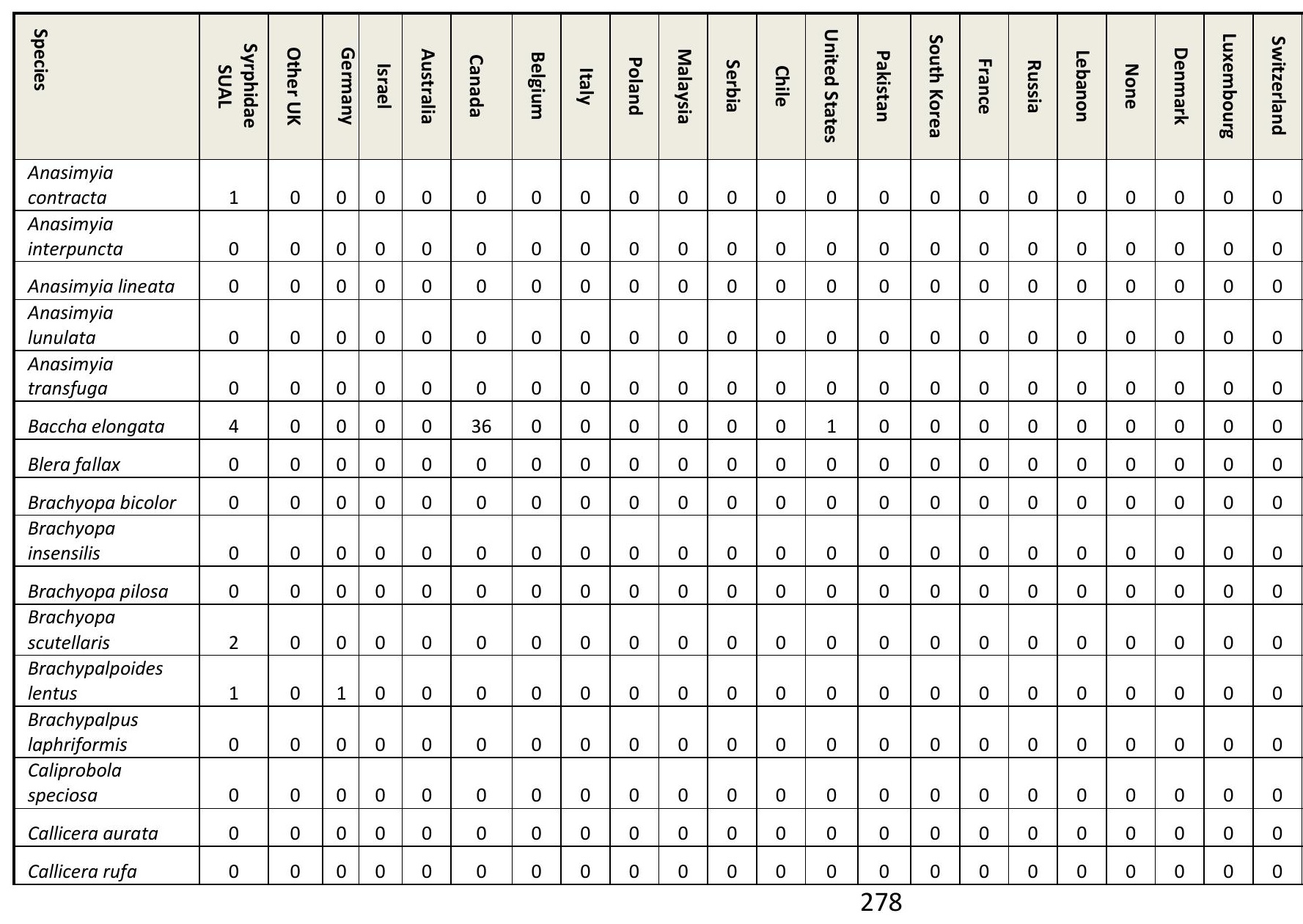




\begin{tabular}{|c|c|c|c|c|c|c|c|c|c|c|c|c|c|c|c|c|c|c|c|c|c|c|}
\hline 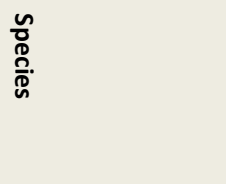 & 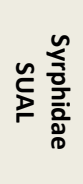 & 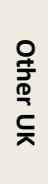 & 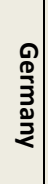 & $\begin{array}{l}\overline{\underline{n}} \\
\mathbb{D} \\
\underline{\mathbb{D}}\end{array}$ & 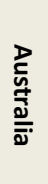 & 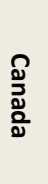 & 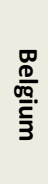 & $\frac{\bar{\Phi}}{2}$ & $\begin{array}{l}\frac{0}{2} \\
\frac{0}{2}\end{array}$ & $\begin{array}{l}\frac{3}{0 .} \\
\frac{0}{2} \\
\frac{\underline{4}}{2}\end{array}$ & $\begin{array}{l}\tilde{\Phi} \\
\frac{\mathbb{D}}{\frac{\sigma}{N}}\end{array}$ & $\frac{9}{\overline{\bar{D}}}$ & 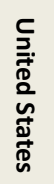 & 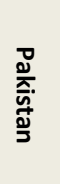 & 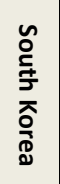 & 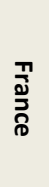 & 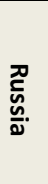 & $\begin{array}{l}\frac{5}{0} \\
\frac{0}{2} \\
\frac{3}{3} \\
\frac{0}{3}\end{array}$ & $\begin{array}{l}2 \\
\text { Z } \\
\stackrel{0}{0}\end{array}$ & $\begin{array}{l}\text { ס } \\
\stackrel{0}{3} \\
3 \\
\frac{2}{\lambda} \\
\frac{3}{\lambda}\end{array}$ & 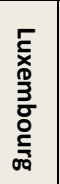 & 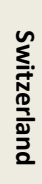 \\
\hline Callicera spinolae & 0 & 0 & 0 & 0 & 0 & 0 & 0 & 0 & 0 & 0 & 0 & 0 & 0 & 0 & 0 & 0 & 0 & 0 & 0 & 0 & 0 & 0 \\
\hline $\begin{array}{l}\text { Chalcosyrphus } \\
\text { eunotus }\end{array}$ & 0 & 0 & 0 & 0 & 0 & 0 & 0 & 0 & 0 & 0 & 0 & 0 & 0 & 0 & 0 & 0 & 0 & 0 & 0 & 0 & 0 & 0 \\
\hline $\begin{array}{l}\text { Chalcosyrphus } \\
\text { nemorum }\end{array}$ & 3 & 0 & 0 & 0 & 0 & 59 & 0 & 0 & 0 & 0 & 0 & 0 & 0 & 0 & 0 & 0 & 0 & 0 & 0 & 0 & 0 & 0 \\
\hline Cheilosia ahenea & 0 & 0 & 0 & 0 & 0 & 0 & 0 & 0 & 0 & 0 & 0 & 0 & 0 & 0 & 0 & 0 & 0 & 0 & 0 & 0 & 0 & 0 \\
\hline Cheilosia albipila & 0 & 0 & 0 & 0 & 0 & 0 & 0 & 0 & 0 & 0 & 0 & 0 & 0 & 0 & 0 & 0 & 0 & 0 & 0 & 0 & 0 & 0 \\
\hline Cheilosia albitarsis & 4 & 0 & 1 & 0 & 0 & 0 & 0 & 0 & 0 & 0 & 0 & 0 & 0 & 0 & 0 & 0 & 0 & 0 & 0 & 0 & 0 & 0 \\
\hline Cheilosia antiqua & 0 & 0 & 0 & 0 & 0 & 0 & 0 & 0 & 0 & 0 & 0 & 0 & 0 & 0 & 0 & 0 & 0 & 0 & 0 & 0 & 0 & 0 \\
\hline Cheilosia barbata & 0 & 0 & 0 & 0 & 0 & 0 & 0 & 0 & 0 & 0 & 0 & 0 & 0 & 0 & 0 & 0 & 0 & 0 & 0 & 0 & 0 & 0 \\
\hline $\begin{array}{l}\text { Cheilosia } \\
\text { bergenstammi }\end{array}$ & 3 & 0 & 0 & 0 & 0 & 0 & 0 & 0 & 0 & 0 & 0 & 0 & 0 & 0 & 0 & 0 & 0 & 0 & 0 & 0 & 0 & 0 \\
\hline $\begin{array}{l}\text { Cheilosia } \\
\text { caerulescens }\end{array}$ & 0 & 0 & 0 & 0 & 0 & 0 & 0 & 0 & 0 & 0 & 0 & 0 & 0 & 0 & 0 & 1 & 0 & 0 & 0 & 0 & 0 & 0 \\
\hline $\begin{array}{l}\text { Cheilosia } \\
\text { carbonaria }\end{array}$ & 0 & 0 & 1 & 0 & 0 & 0 & 0 & 0 & 0 & 0 & 0 & 0 & 0 & 0 & 0 & 0 & 0 & 0 & 0 & 0 & 0 & 0 \\
\hline $\begin{array}{l}\text { Cheilosia } \\
\text { chrysocoma }\end{array}$ & 0 & 0 & 0 & 0 & 0 & 0 & 0 & 0 & 0 & 0 & 0 & 0 & 0 & 0 & 0 & 0 & 0 & 0 & 0 & 0 & 0 & 0 \\
\hline $\begin{array}{l}\text { Cheilosia } \\
\text { cynocephala }\end{array}$ & 0 & 0 & 0 & 0 & 0 & 0 & 0 & 0 & 0 & 0 & 0 & 0 & 0 & 0 & 0 & 0 & 0 & 0 & 0 & 0 & 0 & 0 \\
\hline Cheilosia fraterna & 4 & 0 & 0 & 0 & 0 & 0 & 0 & 0 & 0 & 0 & 0 & 0 & 0 & 0 & 0 & 0 & 0 & 0 & 0 & 0 & 0 & 0 \\
\hline $\begin{array}{l}\text { Cheilosia } \\
\text { griseiventris }\end{array}$ & 0 & 0 & 0 & 0 & 0 & 0 & 0 & 0 & 0 & 0 & 0 & 0 & 0 & 0 & 0 & 0 & 0 & 0 & 0 & 0 & 0 & 0 \\
\hline Cheilosia grossa & 0 & 0 & 2 & 0 & 0 & 0 & 0 & 0 & 0 & 0 & 0 & 0 & 0 & 0 & 0 & 0 & 0 & 0 & 0 & 0 & 0 & 0 \\
\hline Cheilosia illustrata & 4 & 0 & 0 & 0 & 0 & 0 & 0 & 0 & 0 & 0 & 0 & 0 & 0 & 0 & 0 & 0 & 0 & 0 & 0 & 0 & 0 & 0 \\
\hline Cheilosia impressa & 3 & 0 & 0 & 0 & 0 & 0 & 0 & 0 & 0 & 0 & 0 & 0 & 0 & 0 & 0 & 0 & 0 & 0 & 0 & 0 & 0 & 0 \\
\hline Cheilosia lasiopa & 0 & 0 & 0 & 0 & 0 & 0 & 0 & 0 & 0 & 0 & 0 & 0 & 0 & 0 & 0 & 0 & 0 & 0 & 0 & 0 & 0 & 0 \\
\hline Cheilosia latifrons & 0 & 0 & 0 & 0 & 0 & 0 & 0 & 0 & 0 & 0 & 0 & 0 & 0 & 0 & 0 & 0 & 0 & 0 & 0 & 0 & 0 & 0 \\
\hline Cheilosia longula & 0 & 0 & 0 & 0 & 0 & 0 & 0 & 0 & 0 & 0 & 0 & 0 & 0 & 0 & 0 & 0 & 0 & 0 & 0 & 0 & 0 & 0 \\
\hline Cheilosia mutabilis & 0 & 0 & 2 & 0 & 0 & 0 & 0 & 0 & 0 & 0 & 0 & 0 & 0 & 0 & 0 & 0 & 0 & 0 & 0 & 0 & 0 & 0 \\
\hline
\end{tabular}




\begin{tabular}{|c|c|c|c|c|c|c|c|c|c|c|c|c|c|c|c|c|c|c|c|c|c|c|}
\hline $\begin{array}{l}\frac{n}{0} \\
\text { D. } \\
\frac{n}{p} .\end{array}$ & 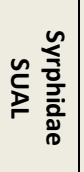 & 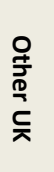 & 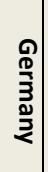 & $\begin{array}{l}\overline{\underline{n}} \\
\bar{D} \\
\underline{D}\end{array}$ & 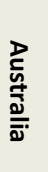 & $\begin{array}{l}\stackrel{\Omega}{2} \\
\frac{2}{2} \\
\frac{0}{2}\end{array}$ & $\begin{array}{l}\frac{\mathbb{0}}{\frac{0}{0}} \\
\frac{000}{0.0} \\
\frac{5}{3}\end{array}$ & $\frac{\overline{\bar{d}}}{2}$ & $\begin{array}{l}\frac{2}{2} \\
\frac{0}{2} \\
\frac{2}{2}\end{array}$ & 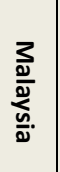 & $\begin{array}{l}\tilde{D} \\
\frac{\mathbb{D}}{\sigma} \\
\frac{\bar{\sigma}}{\mathbb{N}}\end{array}$ & $\frac{\rho}{\overline{\bar{D}}}$ & 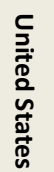 & 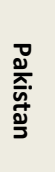 & 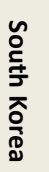 & 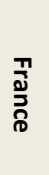 & 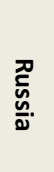 & \begin{tabular}{l}
$\overline{0}$ \\
$\frac{0}{2}$ \\
\multirow{2}{2}{} \\
$\frac{1}{3}$
\end{tabular} & 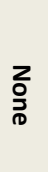 & 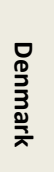 & 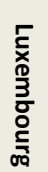 & 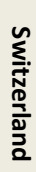 \\
\hline Cheilosia nebulosa & 0 & 0 & 0 & 0 & 0 & 0 & 0 & 0 & 0 & 0 & 0 & 0 & 0 & 0 & 0 & 0 & 0 & 0 & 0 & 0 & 0 & 0 \\
\hline Cheilosia nigripes & 0 & 0 & 0 & 0 & 0 & 0 & 0 & 0 & 0 & 0 & 0 & 0 & 0 & 0 & 0 & 0 & 0 & 0 & 0 & 0 & 0 & 0 \\
\hline Cheilosia pagana & 4 & 0 & 1 & 0 & 0 & 0 & 0 & 0 & 0 & 0 & 0 & 0 & 0 & 0 & 0 & 0 & 0 & 0 & 0 & 0 & 0 & 0 \\
\hline Cheilosia proxima & 4 & 0 & 6 & 0 & 0 & 0 & 0 & 0 & 0 & 0 & 0 & 0 & 0 & 0 & 0 & 0 & 0 & 0 & 0 & 0 & 0 & 0 \\
\hline $\begin{array}{l}\text { Cheilosia } \\
\text { psilophthalma }\end{array}$ & 0 & 0 & 0 & 0 & 0 & 0 & 0 & 0 & 0 & 0 & 0 & 0 & 0 & 0 & 0 & 0 & 0 & 0 & 0 & 0 & 0 & 0 \\
\hline Cheilosia pubera & 0 & 0 & 0 & 0 & 0 & 0 & 0 & 0 & 0 & 0 & 0 & 0 & 0 & 0 & 0 & 0 & 0 & 0 & 0 & 0 & 0 & 0 \\
\hline Cheilosia ranunculi & 0 & 0 & 0 & 0 & 0 & 0 & 0 & 0 & 0 & 0 & 0 & 0 & 0 & 0 & 0 & 0 & 0 & 0 & 0 & 0 & 0 & 0 \\
\hline Cheilosia sahlbergi & 0 & 0 & 0 & 0 & 0 & 0 & 0 & 0 & 0 & 0 & 0 & 0 & 0 & 0 & 0 & 0 & 0 & 0 & 0 & 0 & 0 & 0 \\
\hline $\begin{array}{l}\text { Cheilosia } \\
\text { scutellata }\end{array}$ & 3 & 0 & 0 & 0 & 0 & 0 & 0 & 0 & 0 & 0 & 0 & 0 & 0 & 0 & 0 & 0 & 0 & 0 & 0 & 0 & 0 & 0 \\
\hline $\begin{array}{l}\text { Cheilosia } \\
\text { semifasciata }\end{array}$ & 0 & 0 & 0 & 0 & 0 & 0 & 0 & 0 & 0 & 0 & 0 & 0 & 0 & 0 & 0 & 0 & 0 & 0 & 0 & 0 & 0 & 0 \\
\hline Cheilosia soror & 0 & 0 & 5 & 0 & 0 & 0 & 0 & 0 & 0 & 0 & 0 & 0 & 0 & 0 & 0 & 0 & 0 & 0 & 0 & 0 & 0 & 0 \\
\hline Cheilosia urbana & 0 & 0 & 0 & 0 & 0 & 0 & 0 & 0 & 0 & 0 & 0 & 0 & 0 & 0 & 0 & 0 & 0 & 0 & 0 & 0 & 0 & 0 \\
\hline Cheilosia uviformis & 0 & 0 & 0 & 0 & 0 & 0 & 0 & 0 & 0 & 0 & 0 & 0 & 0 & 0 & 0 & 0 & 0 & 0 & 0 & 0 & 0 & 0 \\
\hline Cheilosia variabilis & 3 & 0 & 0 & 0 & 0 & 0 & 0 & 0 & 0 & 0 & 0 & 0 & 0 & 0 & 0 & 0 & 0 & 0 & 0 & 0 & 0 & 0 \\
\hline Cheilosia velutina & 0 & 0 & 0 & 0 & 0 & 0 & 0 & 0 & 0 & 0 & 0 & 0 & 0 & 0 & 0 & 0 & 0 & 0 & 0 & 0 & 0 & 0 \\
\hline Cheilosia vernalis & 3 & 0 & 0 & 0 & 0 & 0 & 0 & 0 & 0 & 0 & 0 & 0 & 0 & 0 & 0 & 0 & 0 & 0 & 0 & 0 & 0 & 0 \\
\hline Cheilosia vicinia & 0 & 0 & 0 & 0 & 0 & 0 & 0 & 0 & 0 & 0 & 0 & 0 & 0 & 0 & 0 & 0 & 0 & 0 & 0 & 0 & 0 & 0 \\
\hline Cheilosia vulpina & 0 & 0 & 0 & 0 & 0 & 0 & 0 & 0 & 0 & 0 & 0 & 0 & 0 & 0 & 0 & 0 & 0 & 0 & 0 & 0 & 0 & 0 \\
\hline $\begin{array}{l}\text { Chrysogaster } \\
\text { cemiteriorum }\end{array}$ & 0 & 0 & 0 & 0 & 0 & 0 & 0 & 0 & 0 & 0 & 0 & 0 & 0 & 0 & 0 & 0 & 0 & 0 & 0 & 0 & 0 & 0 \\
\hline $\begin{array}{l}\text { Chrysogaster } \\
\text { solstitialis }\end{array}$ & 3 & 0 & 0 & 0 & 0 & 0 & 0 & 0 & 0 & 0 & 0 & 0 & 0 & 0 & 0 & 0 & 0 & 0 & 0 & 0 & 0 & 0 \\
\hline $\begin{array}{l}\text { Chrysogaster } \\
\text { virescens }\end{array}$ & 0 & 0 & 0 & 0 & 0 & 0 & 0 & 0 & 0 & 0 & 0 & 0 & 0 & 0 & 0 & 0 & 0 & 0 & 0 & 0 & 0 & 0 \\
\hline $\begin{array}{l}\text { Chrysotoxum } \\
\text { arcuatum }\end{array}$ & 1 & 0 & 7 & 0 & 0 & 0 & 0 & 0 & 0 & 0 & 0 & 0 & 0 & 0 & 0 & 0 & 0 & 0 & 0 & 0 & 0 & 0 \\
\hline
\end{tabular}




\begin{tabular}{|c|c|c|c|c|c|c|c|c|c|c|c|c|c|c|c|c|c|c|c|c|c|c|}
\hline 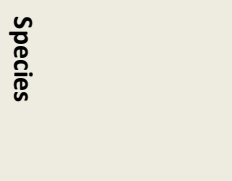 & 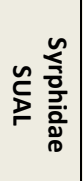 & $\begin{array}{l}\text { 올 } \\
\stackrel{+}{\overline{0}} \\
\stackrel{0}{c} \\
\text { 듯 }\end{array}$ & \begin{tabular}{l}
$\stackrel{Q}{0}$ \\
$\stackrel{0}{3}$ \\
\multirow{3}{0}{} \\
$\stackrel{2}{2}$
\end{tabular} & $\begin{array}{l}\overline{\underline{n}} \\
\stackrel{\Xi}{\mathbb{D}} \\
\end{array}$ & 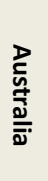 & $\begin{array}{l}\stackrel{8}{2} \\
\frac{\mathscr{2}}{2}\end{array}$ & 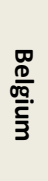 & $\stackrel{\bar{\Phi}}{\gtrless}$ & $\begin{array}{l}\frac{0}{0} \\
\frac{0}{2} \\
\text { בे }\end{array}$ & $\frac{3}{\frac{3}{2}}$ & $\begin{array}{l}\tilde{\text { D }} \\
\frac{\bar{\sigma}}{\frac{v}{v}}\end{array}$ & $\frac{\rho}{\overline{\bar{D}}}$ & 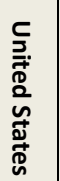 & 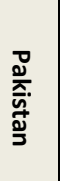 & 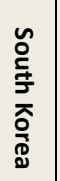 & 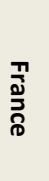 & 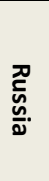 & $\begin{array}{l}\sqrt[5]{0} \\
\stackrel{0}{0} \\
\frac{0}{3} \\
0\end{array}$ & $\begin{array}{l}z \\
0 \\
0 \\
0\end{array}$ & 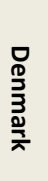 & 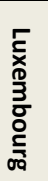 & 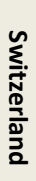 \\
\hline $\begin{array}{l}\text { Chrysotoxum } \\
\text { bicinctum }\end{array}$ & 4 & 0 & 4 & 0 & 0 & 0 & 0 & 0 & 0 & 0 & 0 & 0 & 0 & 0 & 0 & 0 & 0 & 0 & 0 & 0 & 0 & 0 \\
\hline $\begin{array}{l}\text { Chrysotoxum } \\
\text { cautum }\end{array}$ & 1 & 0 & $\begin{array}{l}1 \\
7 \\
\end{array}$ & 0 & 0 & 0 & 0 & 0 & 0 & 0 & 0 & 0 & 0 & 0 & 0 & 0 & 0 & 0 & 0 & 0 & 0 & 0 \\
\hline $\begin{array}{l}\text { Chrysotoxum } \\
\text { elegans }\end{array}$ & 0 & 0 & 0 & 0 & 0 & 0 & 0 & 0 & 0 & 0 & 0 & 0 & 0 & 0 & 0 & 0 & 0 & 0 & 0 & 0 & 0 & 0 \\
\hline $\begin{array}{l}\text { Chrysotoxum } \\
\text { festivum }\end{array}$ & 0 & 0 & 0 & 0 & 0 & 0 & 0 & 0 & 0 & 0 & 0 & 0 & 0 & 0 & 0 & 0 & 0 & 0 & 0 & 0 & 0 & 0 \\
\hline $\begin{array}{l}\text { Chrysotoxum } \\
\text { octomaculatum }\end{array}$ & 0 & 0 & 0 & 0 & 0 & 0 & 0 & 0 & 0 & 0 & 0 & 0 & 0 & 0 & 0 & 0 & 0 & 0 & 0 & 0 & 0 & 0 \\
\hline $\begin{array}{l}\text { Chrysotoxum } \\
\text { vernale }\end{array}$ & 0 & 0 & 0 & 0 & 0 & 0 & 0 & 0 & 0 & 0 & 0 & 0 & 0 & 0 & 0 & 0 & 0 & 0 & 0 & 0 & 0 & 0 \\
\hline $\begin{array}{l}\text { Chrysotoxum } \\
\text { verralli }\end{array}$ & 0 & 0 & 0 & 0 & 0 & 0 & 0 & 0 & 0 & 0 & 0 & 0 & 0 & 0 & 0 & 0 & 0 & 0 & 0 & 0 & 0 & 0 \\
\hline Criorhina asilica & 0 & 0 & 1 & 0 & 0 & 0 & 0 & 0 & 0 & 0 & 0 & 0 & 0 & 0 & 0 & 0 & 0 & 0 & 0 & 0 & 0 & 0 \\
\hline $\begin{array}{l}\text { Criorhina } \\
\text { berberina }\end{array}$ & 0 & 0 & 0 & 0 & 0 & 0 & 0 & 0 & 0 & 0 & 0 & 0 & 0 & 0 & 0 & 0 & 0 & 0 & 0 & 0 & 0 & 0 \\
\hline Criorhina floccosa & 0 & 0 & 0 & 0 & 0 & 0 & 0 & 0 & 0 & 0 & 0 & 0 & 0 & 0 & 0 & 0 & 0 & 0 & 0 & 0 & 0 & 0 \\
\hline Criorhina ranunculi & 4 & 0 & 0 & 0 & 0 & 0 & 0 & 0 & 0 & 0 & 0 & 0 & 0 & 0 & 0 & 0 & 0 & 0 & 0 & 0 & 0 & 0 \\
\hline $\begin{array}{l}\text { Dasysyrphus } \\
\text { albostriatus }\end{array}$ & 3 & 0 & 1 & 0 & 0 & 0 & 0 & 0 & 0 & 0 & 0 & 0 & 0 & 0 & 0 & 0 & 0 & 0 & 0 & 0 & 0 & 0 \\
\hline $\begin{array}{l}\text { Dasysyrphus } \\
\text { friuliensis }\end{array}$ & 0 & 0 & 0 & 0 & 0 & 0 & 0 & 0 & 0 & 0 & 0 & 0 & 0 & 0 & 0 & 0 & 0 & 0 & 0 & 0 & 0 & 0 \\
\hline Dasysyrphus hilaris & 0 & 0 & 0 & 0 & 0 & 0 & 0 & 0 & 0 & 0 & 0 & 0 & 0 & 0 & 0 & 0 & 0 & 0 & 0 & 0 & 0 & 0 \\
\hline $\begin{array}{l}\text { Dasysyrphus } \\
\text { pauxillus }\end{array}$ & 0 & 0 & 0 & 0 & 0 & 7 & 0 & 0 & 0 & 0 & 0 & 0 & 11 & 0 & 0 & 0 & 0 & 0 & 0 & 0 & 0 & 0 \\
\hline $\begin{array}{l}\text { Dasysyrphus } \\
\text { pinastri }\end{array}$ & 0 & 0 & 0 & 0 & 0 & 0 & 0 & 0 & 0 & 0 & 0 & 0 & 0 & 0 & 0 & 0 & 0 & 0 & 0 & 0 & 0 & 0 \\
\hline $\begin{array}{l}\text { Dasysyrphus } \\
\text { tricinctus }\end{array}$ & 1 & 0 & 0 & 0 & 0 & 0 & 0 & 0 & 1 & 0 & 0 & 0 & 0 & 0 & 1 & 0 & 0 & 0 & 0 & 0 & 0 & 0 \\
\hline $\begin{array}{l}\text { Dasysyrphus } \\
\text { venustus }\end{array}$ & 4 & 0 & 2 & 0 & 0 & 58 & 0 & 0 & 0 & 0 & 0 & 0 & 17 & 0 & 5 & 0 & 0 & 0 & 0 & 0 & 0 & 0 \\
\hline Didea alneti & 0 & 0 & 0 & 0 & 0 & 1 & 0 & 0 & 0 & 0 & 0 & 0 & 0 & 0 & 0 & 0 & 0 & 0 & 0 & 0 & 0 & 0 \\
\hline Didea fasciata & 0 & 0 & 0 & 0 & 0 & 0 & 0 & 0 & 0 & 0 & 0 & 0 & 0 & 0 & 0 & 0 & 0 & 0 & 0 & 0 & 0 & 0 \\
\hline
\end{tabular}




\begin{tabular}{|c|c|c|c|c|c|c|c|c|c|c|c|c|c|c|c|c|c|c|c|c|c|c|}
\hline 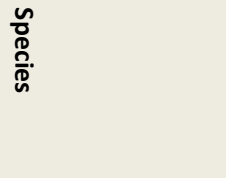 & 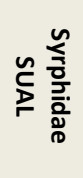 & 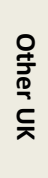 & 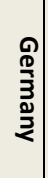 & $\begin{array}{l}\overline{\underline{n}} \\
\stackrel{\mathbb{D}}{\mathbb{D}} \\
\end{array}$ & $\begin{array}{l}\text { D } \\
\frac{1}{4} \\
\frac{1}{3} \\
\frac{\overline{\bar{a}}}{2}\end{array}$ & $\begin{array}{l}\stackrel{8}{3} \\
\frac{2}{2} \\
\frac{2}{2}\end{array}$ & 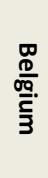 & $\frac{\bar{\Phi}}{2}$ & $\begin{array}{l}\frac{0}{2} \\
\frac{0}{2}\end{array}$ & & 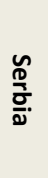 & $\frac{\rho}{\overline{\bar{t}}}$ & 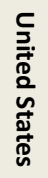 & 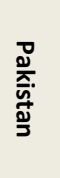 & 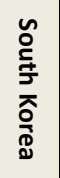 & 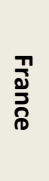 & 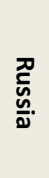 & $\begin{array}{l}\overline{0} \\
\frac{0}{0} \\
\frac{0}{3} \\
0\end{array}$ & 2 & 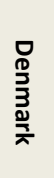 & 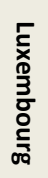 & 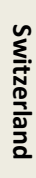 \\
\hline Didea intermedia & 0 & 0 & 0 & 0 & 0 & 0 & 0 & 0 & 0 & 0 & 0 & 0 & 0 & 0 & 0 & 0 & 0 & 0 & 0 & 0 & 0 & 0 \\
\hline Doros profuges & 0 & 0 & 0 & 0 & 0 & 0 & 0 & 0 & 0 & 0 & 0 & 0 & 0 & 0 & 0 & 0 & 0 & 0 & 0 & 0 & 0 & 0 \\
\hline $\begin{array}{l}\text { Epistrophe } \\
\text { diaphana }\end{array}$ & 0 & 0 & 0 & 0 & 0 & 0 & 0 & 0 & 0 & 0 & 0 & 0 & 0 & 0 & 0 & 0 & 0 & 0 & 0 & 0 & 0 & 0 \\
\hline Epistrophe eligans & 4 & 0 & $\begin{array}{l}1 \\
5 \\
\end{array}$ & 0 & 0 & 0 & 0 & 0 & 0 & 0 & 1 & 0 & 0 & 0 & 0 & 0 & 0 & 0 & 0 & 0 & 0 & 0 \\
\hline $\begin{array}{l}\text { Epistrophe } \\
\text { grossulariae }\end{array}$ & 2 & 0 & 2 & 0 & 0 & 7 & 0 & 0 & 0 & 0 & 0 & 0 & 2 & 0 & 0 & 0 & 0 & 0 & 0 & 0 & 0 & 0 \\
\hline $\begin{array}{l}\text { Epistrophe } \\
\text { melanostoma }\end{array}$ & 0 & 0 & 2 & 0 & 0 & 1 & 0 & 0 & 0 & 0 & 0 & 0 & 0 & 0 & 0 & 0 & 0 & 0 & 0 & 0 & 0 & 0 \\
\hline $\begin{array}{l}\text { Epistrophe } \\
\text { nitidicollis }\end{array}$ & 0 & 0 & 7 & 0 & 0 & 3 & 0 & 0 & 0 & 0 & 0 & 0 & 0 & 0 & 0 & 0 & 0 & 0 & 0 & 0 & 0 & 0 \\
\hline $\begin{array}{l}\text { Epistrophe } \\
\text { ochrostoma }\end{array}$ & 0 & 0 & 0 & 0 & 0 & 0 & 0 & 0 & 0 & 0 & 0 & 0 & 0 & 0 & 0 & 0 & 0 & 0 & 0 & 0 & 0 & 0 \\
\hline $\begin{array}{l}\text { Episyrphus } \\
\text { balteatus }\end{array}$ & 4 & 0 & $\begin{array}{l}1 \\
0 \\
1\end{array}$ & 0 & 0 & 0 & 0 & 0 & 0 & 6 & 1 & 0 & 0 & 75 & 0 & 0 & 0 & 0 & 0 & 0 & 0 & 0 \\
\hline $\begin{array}{l}\text { Eriozona } \\
\text { syrphoides }\end{array}$ & 0 & 0 & 0 & 0 & 0 & 0 & 0 & 0 & 0 & 0 & 0 & 0 & 0 & 0 & 0 & 0 & 0 & 0 & 0 & 0 & 0 & 0 \\
\hline Eristalinus aeneus & 4 & 0 & 0 & 0 & 0 & 0 & 0 & 0 & 0 & 0 & 0 & 0 & 0 & 0 & 0 & 0 & 0 & 0 & 0 & 0 & 0 & 0 \\
\hline $\begin{array}{l}\text { Eristalinus } \\
\text { sepulchralis }\end{array}$ & 2 & 0 & 0 & 0 & 0 & 0 & 0 & 0 & 0 & 0 & 0 & 0 & 0 & 0 & 0 & 0 & 0 & 0 & 0 & 0 & 0 & 0 \\
\hline Eristalis abusiva & 0 & 0 & 0 & 0 & 0 & 0 & 0 & 0 & 0 & 0 & 0 & 0 & 0 & 0 & 0 & 0 & 0 & 0 & 0 & 0 & 0 & 0 \\
\hline $\begin{array}{l}\text { Eristalis } \\
\text { arbustorum }\end{array}$ & 4 & 0 & 0 & 0 & 0 & 2 & 0 & 0 & 0 & 0 & 0 & 0 & 1 & 0 & 0 & 0 & 0 & 0 & 0 & 0 & 0 & 0 \\
\hline Eristalis cryptarum & 0 & 0 & 0 & 0 & 0 & 10 & 0 & 0 & 0 & 0 & 0 & 0 & 1 & 0 & 0 & 0 & 0 & 0 & 0 & 0 & 0 & 0 \\
\hline Eristalis horticola & 4 & 0 & 0 & 0 & 0 & 0 & 0 & 0 & 0 & 0 & 0 & 0 & 0 & 0 & 0 & 0 & 0 & 0 & 0 & 0 & 0 & 0 \\
\hline Eristalis intricaria & 4 & 0 & 0 & 0 & 0 & 0 & 0 & 0 & 0 & 0 & 0 & 0 & 0 & 0 & 0 & 0 & 0 & 0 & 0 & 0 & 0 & 0 \\
\hline Eristalis nemorum & 3 & 0 & 0 & 0 & 0 & 0 & 0 & 0 & 0 & 0 & 0 & 0 & 0 & 0 & 0 & 0 & 0 & 0 & 0 & 0 & 0 & 0 \\
\hline Eristalis pertinax & 4 & 0 & $\begin{array}{l}1 \\
4 \\
\end{array}$ & 0 & 0 & 0 & 0 & 0 & 0 & 0 & 0 & 0 & 0 & 0 & 0 & 0 & 0 & 0 & 0 & 0 & 0 & 0 \\
\hline Eristalis rupium & 0 & 0 & 0 & 0 & 0 & 2 & 0 & 0 & 0 & 0 & 0 & 0 & 0 & 0 & 0 & 0 & 0 & 0 & 0 & 0 & 0 & 0 \\
\hline
\end{tabular}




\begin{tabular}{|c|c|c|c|c|c|c|c|c|c|c|c|c|c|c|c|c|c|c|c|c|c|c|}
\hline $\begin{array}{l}\text { n } \\
\text { D } \\
\text { n. }\end{array}$ & 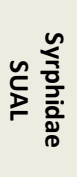 & $\begin{array}{l}\text { 옹 } \\
\stackrel{+}{\overrightarrow{0}} \\
\stackrel{0}{c} \\
\text { c듯 }\end{array}$ & $\begin{array}{l}\text { Q } \\
\stackrel{D}{3} \\
3 \\
\stackrel{2}{2} \\
\sum\end{array}$ & 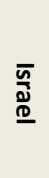 & 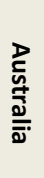 & $\begin{array}{l}\stackrel{0}{3} \\
\text { 음 }\end{array}$ & $\frac{\underset{D}{D}}{\frac{\mathbb{D}}{\sigma a}}$ & $\frac{\bar{\Phi}}{\gtrless}$ & $\begin{array}{l}\frac{0}{0} \\
\frac{\circ}{2} \\
\frac{0}{2}\end{array}$ & $\frac{3}{\frac{a}{0}}$ & 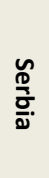 & $\frac{\text { 올 }}{\overline{\bar{D}}}$ & 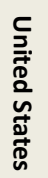 & 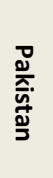 & 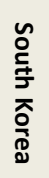 & 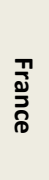 & 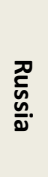 & 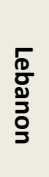 & $\underset{\substack{2 \\
0}}{2}$ & 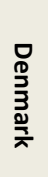 & $\begin{array}{l}5 \\
\frac{1}{x} \\
0 \\
3 \\
\frac{D}{0} \\
0 \\
\frac{0}{0}\end{array}$ & 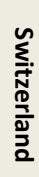 \\
\hline Eristalis similis & 0 & 0 & 1 & 0 & 0 & 0 & 0 & 0 & 0 & 0 & 0 & 0 & 0 & 0 & 0 & 0 & 0 & 0 & 0 & 0 & 0 & 0 \\
\hline Eristalis tenax & 4 & 0 & $\begin{array}{l}1 \\
0 \\
\end{array}$ & 0 & 2 & 24 & 0 & 0 & 0 & 0 & 0 & 0 & 1 & 0 & 0 & 0 & 0 & 0 & 0 & 0 & 0 & 0 \\
\hline Eumerus funeralis & 3 & 0 & 2 & 0 & 0 & 27 & 0 & 0 & 0 & 0 & 0 & 0 & 0 & 0 & 0 & 0 & 0 & 0 & 0 & 0 & 0 & 0 \\
\hline Eumerus ornatus & 0 & 0 & 0 & 0 & 0 & 0 & 0 & 0 & 0 & 0 & 0 & 0 & 0 & 0 & 0 & 0 & 0 & 0 & 0 & 0 & 0 & 0 \\
\hline $\begin{array}{l}\text { Eumerus } \\
\text { sabulonum }\end{array}$ & 0 & 0 & 0 & 0 & 0 & 0 & 0 & 0 & 0 & 0 & 0 & 0 & 0 & 0 & 0 & 0 & 0 & 0 & 0 & 0 & 0 & 0 \\
\hline $\begin{array}{l}\text { Eumerus } \\
\text { sogdianus }\end{array}$ & 0 & 0 & 0 & 0 & 0 & 0 & 0 & 0 & 0 & 0 & 0 & 0 & 0 & 0 & 0 & 0 & 0 & 0 & 0 & 0 & 0 & 0 \\
\hline Eumerus strigatus & 0 & 0 & 0 & 0 & 0 & 7 & 0 & 0 & 0 & 0 & 0 & 1 & 0 & 0 & 0 & 0 & 0 & 0 & 0 & 0 & 0 & 0 \\
\hline $\begin{array}{l}\text { Eupeodes } \\
\text { bucculatus }\end{array}$ & 0 & 0 & 0 & 0 & 0 & 0 & 0 & 0 & 0 & 0 & 0 & 0 & 0 & 0 & 2 & 0 & 0 & 0 & 0 & 0 & 0 & 0 \\
\hline Eupeodes corollae & 4 & 0 & $\begin{array}{l}5 \\
4\end{array}$ & 0 & 0 & 0 & 0 & 1 & 0 & 0 & 0 & 0 & 0 & 29 & 0 & 0 & 0 & 0 & 0 & 0 & 0 & 0 \\
\hline Eupeodes goeldlini & 0 & 0 & 0 & 0 & 0 & 0 & 0 & 0 & 0 & 0 & 0 & 0 & 0 & 0 & 0 & 0 & 0 & 0 & 0 & 0 & 0 & 0 \\
\hline $\begin{array}{l}\text { Eupeodes } \\
\text { Iapponicus }\end{array}$ & 0 & 0 & 2 & 0 & 0 & 13 & 0 & 0 & 0 & 0 & 0 & 0 & 0 & 0 & 0 & 0 & 0 & 0 & 0 & 0 & 0 & 0 \\
\hline $\begin{array}{l}\text { Eupeodes } \\
\text { latifasciatus }\end{array}$ & 0 & 0 & 5 & 0 & 0 & 58 & 0 & 0 & 0 & 0 & 0 & 0 & 0 & 0 & 0 & 0 & 0 & 0 & 0 & 0 & 0 & 0 \\
\hline $\begin{array}{l}\text { Eupeodes } \\
\text { lundbecki }\end{array}$ & 0 & 0 & 0 & 0 & 0 & 0 & 0 & 0 & 0 & 0 & 0 & 0 & 0 & 0 & 0 & 0 & 0 & 0 & 0 & 0 & 0 & 0 \\
\hline Eupeodes luniger & 4 & 0 & 2 & 0 & 0 & 1 & 0 & 0 & 0 & 0 & 0 & 0 & 2 & 0 & 0 & 0 & 0 & 0 & 0 & 0 & 0 & 0 \\
\hline Eupeodes nielseni & 0 & 0 & 0 & 0 & 0 & 0 & 0 & 0 & 0 & 0 & 0 & 0 & 0 & 0 & 0 & 0 & 0 & 0 & 0 & 0 & 0 & 0 \\
\hline Eupeodes nitens & 0 & 0 & 0 & 0 & 0 & 0 & 0 & 0 & 0 & 0 & 0 & 0 & 0 & 0 & 0 & 0 & 0 & 0 & 0 & 0 & 0 & 0 \\
\hline $\begin{array}{l}\text { Ferdinandea } \\
\text { cuprea }\end{array}$ & 2 & 0 & 4 & 0 & 0 & 0 & 0 & 0 & 0 & 0 & 0 & 0 & 0 & 0 & 0 & 0 & 0 & 0 & 0 & 0 & 0 & 0 \\
\hline $\begin{array}{l}\text { Ferdinandea } \\
\text { ruficornis }\end{array}$ & 0 & 0 & 1 & 0 & 0 & 0 & 0 & 0 & 0 & 0 & 0 & 0 & 0 & 0 & 0 & 0 & 0 & 0 & 0 & 0 & 0 & 0 \\
\hline $\begin{array}{l}\text { Hammerschmidtia } \\
\text { ferruginea }\end{array}$ & 0 & 0 & 0 & 0 & 0 & 0 & 0 & 0 & 0 & 0 & 0 & 0 & 0 & 0 & 0 & 0 & 0 & 0 & 0 & 0 & 0 & 0 \\
\hline Helophilus affinis & 0 & 0 & 0 & 0 & 0 & 0 & 0 & 0 & 0 & 0 & 0 & 0 & 0 & 0 & 0 & 0 & 0 & 0 & 0 & 0 & 0 & 0 \\
\hline $\begin{array}{l}\text { Helophilus } \\
\text { groenlandicus }\end{array}$ & 0 & 0 & 0 & 0 & 0 & 19 & 0 & 0 & 0 & 0 & 0 & 0 & 0 & 0 & 0 & 0 & 0 & 0 & 0 & 0 & 0 & 0 \\
\hline
\end{tabular}




\begin{tabular}{|c|c|c|c|c|c|c|c|c|c|c|c|c|c|c|c|c|c|c|c|c|c|c|}
\hline 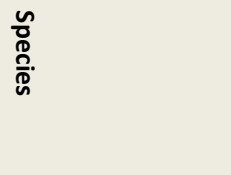 & 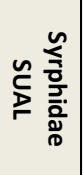 & $\begin{array}{l}\text { 올 } \\
\stackrel{+}{\overline{0}} \\
\stackrel{0}{c} \\
\text { 듯 }\end{array}$ & \begin{tabular}{l}
$\stackrel{Q}{0}$ \\
$\stackrel{0}{3}$ \\
\multirow{3}{0}{} \\
$\stackrel{2}{2}$
\end{tabular} & $\begin{array}{l}\overline{\underline{w}} \\
\overline{\underline{D}} \\
\underline{\underline{\omega}}\end{array}$ & 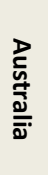 & $\begin{array}{l}\stackrel{8}{2} \\
\frac{\mathscr{2}}{2}\end{array}$ & 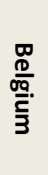 & $\stackrel{\bar{\Phi}}{\gtrless}$ & $\begin{array}{l}\frac{0}{0} \\
\frac{0}{2} \\
\text { בे }\end{array}$ & $\frac{3}{\frac{3}{2}}$ & $\begin{array}{l}\tilde{\text { D }} \\
\frac{\bar{\sigma}}{\frac{v}{v}}\end{array}$ & $\frac{\text { 울 }}{\overline{1}}$ & 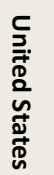 & 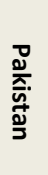 & 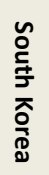 & 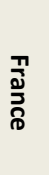 & 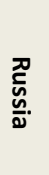 & $\begin{array}{l}\sqrt[5]{0} \\
\stackrel{0}{0} \\
\frac{0}{3} \\
0\end{array}$ & $\begin{array}{l}z \\
0 \\
0 \\
0\end{array}$ & 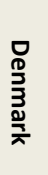 & 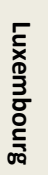 & 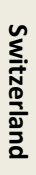 \\
\hline $\begin{array}{l}\text { Helophilus } \\
\text { hybridus }\end{array}$ & 3 & 0 & 3 & 0 & 0 & 59 & 0 & 0 & 0 & 0 & 0 & 0 & 1 & 0 & 0 & 0 & 0 & 0 & 0 & 0 & 0 & 0 \\
\hline $\begin{array}{l}\text { Helophilus } \\
\text { pendulus }\end{array}$ & 4 & 0 & 6 & 0 & 0 & 1 & 0 & 0 & 0 & 0 & 0 & 0 & 0 & 0 & 0 & 0 & 0 & 0 & 0 & 0 & 0 & 0 \\
\hline $\begin{array}{l}\text { Helophilus } \\
\text { trivittatus }\end{array}$ & 3 & 0 & $\begin{array}{l}1 \\
2\end{array}$ & 0 & 0 & 0 & 0 & 0 & 0 & 0 & 0 & 0 & 0 & 0 & 0 & 0 & 0 & 0 & 0 & 0 & 0 & 0 \\
\hline Heringia brevidens & 0 & 0 & 0 & 0 & 0 & 0 & 0 & 0 & 0 & 0 & 0 & 0 & 0 & 0 & 0 & 0 & 0 & 0 & 0 & 0 & 0 & 0 \\
\hline Heringia heringi & 0 & 0 & 0 & 0 & 0 & 0 & 0 & 0 & 0 & 0 & 0 & 0 & 0 & 0 & 0 & 0 & 0 & 0 & 0 & 0 & 0 & 0 \\
\hline Heringia latitarsis & 0 & 0 & 0 & 0 & 0 & 0 & 0 & 0 & 0 & 0 & 0 & 0 & 0 & 0 & 0 & 0 & 0 & 0 & 0 & 0 & 0 & 0 \\
\hline $\begin{array}{l}\text { Heringia } \\
\text { pubescens }\end{array}$ & 0 & 0 & 0 & 0 & 0 & 0 & 0 & 0 & 0 & 0 & 0 & 0 & 0 & 0 & 0 & 0 & 0 & 0 & 0 & 0 & 0 & 0 \\
\hline Heringia senilis & 0 & 0 & 0 & 0 & 0 & 0 & 0 & 0 & 0 & 0 & 0 & 0 & 0 & 0 & 0 & 0 & 0 & 0 & 0 & 0 & 0 & 0 \\
\hline Heringia verrucula & 0 & 0 & 0 & 0 & 0 & 0 & 0 & 0 & 0 & 0 & 0 & 0 & 0 & 0 & 0 & 0 & 0 & 0 & 0 & 0 & 0 & 0 \\
\hline $\begin{array}{l}\text { Heringia } \\
\text { vitripennis }\end{array}$ & 0 & 0 & 0 & 0 & 0 & 0 & 0 & 0 & 0 & 0 & 0 & 0 & 0 & 0 & 0 & 0 & 0 & 0 & 0 & 0 & 0 & 0 \\
\hline $\begin{array}{l}\text { Lejogaster } \\
\text { metallina }\end{array}$ & 0 & 0 & 0 & 0 & 0 & 0 & 0 & 0 & 0 & 0 & 0 & 0 & 0 & 0 & 0 & 0 & 0 & 0 & 0 & 0 & 0 & 0 \\
\hline Lejogaster tarsata & 0 & 0 & 0 & 0 & 0 & 0 & 0 & 0 & 0 & 0 & 0 & 0 & 0 & 0 & 0 & 0 & 0 & 0 & 0 & 0 & 0 & 0 \\
\hline Lejops vittatus & 0 & 0 & 0 & 0 & 0 & 0 & 0 & 0 & 0 & 0 & 0 & 0 & 0 & 0 & 0 & 0 & 0 & 0 & 0 & 0 & 0 & 0 \\
\hline Leucozona glaucia & 4 & 0 & 0 & 0 & 0 & 0 & 0 & 0 & 0 & 0 & 0 & 0 & 0 & 0 & 0 & 0 & 0 & 0 & 0 & 0 & 0 & 0 \\
\hline $\begin{array}{l}\text { Leucozona } \\
\text { laternaria }\end{array}$ & 1 & 0 & 0 & 0 & 0 & 0 & 0 & 0 & 0 & 0 & 0 & 0 & 0 & 0 & 0 & 0 & 0 & 0 & 0 & 0 & 0 & 0 \\
\hline $\begin{array}{l}\text { Leucozona } \\
\text { lucorum }\end{array}$ & 3 & 0 & 0 & 0 & 0 & 2 & 0 & 0 & 0 & 0 & 0 & 0 & 0 & 0 & 0 & 0 & 0 & 0 & 0 & 0 & 0 & 0 \\
\hline $\begin{array}{l}\text { Mallota } \\
\text { cimbiciformis }\end{array}$ & 0 & 0 & 0 & 0 & 0 & 0 & 0 & 0 & 0 & 0 & 0 & 0 & 0 & 0 & 0 & 0 & 0 & 0 & 0 & 0 & 0 & 0 \\
\hline $\begin{array}{l}\text { Megasyrphus } \\
\text { erraticus }\end{array}$ & 0 & 0 & 0 & 0 & 0 & 0 & 0 & 0 & 0 & 0 & 0 & 0 & 0 & 0 & 0 & 0 & 0 & 0 & 0 & 0 & 0 & 0 \\
\hline Melangyna arctica & 0 & 0 & 0 & 0 & 0 & 16 & 0 & 0 & 0 & 0 & 0 & 0 & 2 & 0 & 0 & 0 & 0 & 0 & 0 & 0 & 0 & 0 \\
\hline $\begin{array}{l}\text { Melangyna } \\
\text { barbifrons }\end{array}$ & 0 & 0 & 0 & 0 & 0 & 0 & 0 & 0 & 0 & 0 & 0 & 0 & 0 & 0 & 0 & 0 & 0 & 0 & 0 & 0 & 0 & 0 \\
\hline Melangyna cincta & 0 & 0 & 0 & 0 & 0 & 0 & 0 & 0 & 0 & 0 & 0 & 0 & 0 & 0 & 0 & 0 & 0 & 0 & 0 & 0 & 0 & 0 \\
\hline
\end{tabular}




\begin{tabular}{|c|c|c|c|c|c|c|c|c|c|c|c|c|c|c|c|c|c|c|c|c|c|c|}
\hline 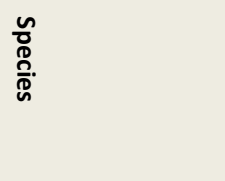 & 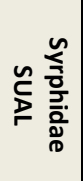 & 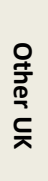 & 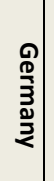 & $\begin{array}{l}\overline{\underline{n}} \\
\overline{\mathbb{N}} \\
\underline{\underline{D}}\end{array}$ & 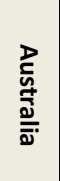 & 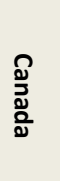 & 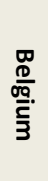 & $\stackrel{\bar{\Phi}}{\gtrless}$ & $\begin{array}{l}\frac{0}{2} \\
\frac{0}{2} \\
\text { בे }\end{array}$ & & $\begin{array}{l}\widetilde{\infty} \\
\frac{\mathbb{D}}{\sigma} \\
\frac{\sigma}{\mathbb{N}}\end{array}$ & $\frac{9}{\overline{\bar{D}}}$ & 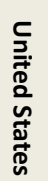 & 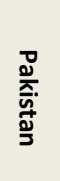 & 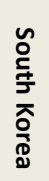 & 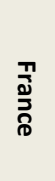 & 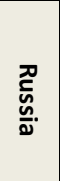 & 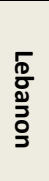 & zo & 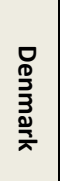 & 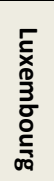 & 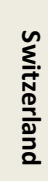 \\
\hline $\begin{array}{l}\text { Melangyna } \\
\text { compositarum }\end{array}$ & 0 & 0 & 0 & 0 & 0 & 4 & 0 & 0 & 0 & 0 & 0 & 0 & 0 & 0 & 0 & 0 & 0 & 0 & 0 & 0 & 0 & 0 \\
\hline $\begin{array}{l}\text { Melangyna } \\
\text { ericarum }\end{array}$ & 0 & 0 & 0 & 0 & 0 & 0 & 0 & 0 & 0 & 0 & 0 & 0 & 0 & 0 & 0 & 0 & 0 & 0 & 0 & 0 & 0 & 0 \\
\hline $\begin{array}{l}\text { Melangyna } \\
\text { labiatarum }\end{array}$ & 0 & 0 & 0 & 0 & 0 & 11 & 0 & 0 & 0 & 0 & 0 & 0 & 0 & 0 & 0 & 0 & 0 & 0 & 0 & 0 & 0 & 0 \\
\hline $\begin{array}{l}\text { Melangyna } \\
\text { lasiophthalma }\end{array}$ & 0 & 0 & 1 & 0 & 0 & 24 & 0 & 0 & 0 & 0 & 0 & 0 & 0 & 0 & 0 & 0 & 0 & 0 & 0 & 0 & 0 & 0 \\
\hline $\begin{array}{l}\text { Melangyna } \\
\text { quadrimaculata }\end{array}$ & 0 & 0 & 0 & 0 & 0 & 0 & 0 & 0 & 0 & 0 & 0 & 0 & 0 & 0 & 0 & 0 & 0 & 0 & 0 & 0 & 0 & 0 \\
\hline $\begin{array}{l}\text { Melangyna } \\
\text { umbellatarum }\end{array}$ & 0 & 0 & 0 & 0 & 0 & 1 & 0 & 0 & 0 & 0 & 0 & 0 & 0 & 0 & 0 & 0 & 0 & 0 & 0 & 0 & 0 & 0 \\
\hline $\begin{array}{l}\text { Melanogaster } \\
\text { aerosa }\end{array}$ & 0 & 0 & 0 & 0 & 0 & 0 & 0 & 0 & 0 & 0 & 0 & 0 & 0 & 0 & 0 & 0 & 0 & 0 & 0 & 0 & 0 & 0 \\
\hline $\begin{array}{l}\text { Melanogaster } \\
\text { hirtella }\end{array}$ & 4 & 0 & 0 & 0 & 0 & 0 & 0 & 0 & 0 & 0 & 0 & 0 & 0 & 0 & 0 & 0 & 0 & 0 & 0 & 0 & 0 & 0 \\
\hline $\begin{array}{l}\text { Melanostoma } \\
\text { dubium }\end{array}$ & 0 & 0 & 0 & 0 & 0 & 0 & 0 & 0 & 0 & 0 & 0 & 0 & 0 & 0 & 0 & 0 & 0 & 0 & 0 & 0 & 0 & 0 \\
\hline $\begin{array}{l}\text { Melanostoma } \\
\text { mellinum }\end{array}$ & 4 & 0 & 0 & 0 & 0 & 60 & 0 & 0 & 0 & 0 & 4 & 0 & 28 & 0 & 0 & 0 & 0 & 0 & 0 & 0 & 0 & 0 \\
\hline $\begin{array}{l}\text { Melanostoma } \\
\text { scalare }\end{array}$ & 4 & 0 & 0 & 0 & 0 & 0 & 0 & 0 & 0 & 0 & 0 & 0 & 0 & 0 & 0 & 0 & 0 & 0 & 0 & 0 & 0 & 0 \\
\hline $\begin{array}{l}\text { Meligramma } \\
\text { euchromum }\end{array}$ & 0 & 0 & 0 & 0 & 0 & 0 & 0 & 0 & 0 & 0 & 0 & 0 & 0 & 0 & 0 & 0 & 0 & 0 & 0 & 0 & 0 & 0 \\
\hline $\begin{array}{l}\text { Meligramma } \\
\text { guttatum }\end{array}$ & 0 & 0 & 0 & 0 & 0 & 0 & 0 & 0 & 0 & 0 & 0 & 0 & 0 & 0 & 0 & 0 & 0 & 0 & 0 & 0 & 0 & 0 \\
\hline $\begin{array}{l}\text { Meligramma } \\
\text { trianguliferum }\end{array}$ & 0 & 0 & 0 & 0 & 0 & 0 & 0 & 0 & 0 & 0 & 0 & 0 & 0 & 0 & 0 & 0 & 0 & 0 & 0 & 0 & 0 & 0 \\
\hline $\begin{array}{l}\text { Meliscaeva } \\
\text { auricollis }\end{array}$ & 4 & 0 & 0 & 1 & 0 & 0 & 0 & 0 & 0 & 0 & 0 & 0 & 0 & 0 & 0 & 0 & 0 & 0 & 0 & 0 & 0 & 0 \\
\hline $\begin{array}{l}\text { Meliscaeva } \\
\text { cinctella }\end{array}$ & 4 & 0 & 1 & 0 & 0 & 87 & 0 & 0 & 0 & 0 & 0 & 0 & 2 & 0 & 0 & 0 & 0 & 0 & 0 & 0 & 0 & 0 \\
\hline Merodon equestris & 3 & 0 & $\begin{array}{l}1 \\
0 \\
\end{array}$ & 0 & 0 & 4 & 0 & 0 & 0 & 0 & 0 & 0 & 0 & 0 & 0 & 0 & 0 & 0 & 0 & 0 & 0 & 0 \\
\hline Microdon analis & 0 & 0 & 0 & 0 & 0 & 0 & 0 & 0 & 0 & 0 & 0 & 0 & 0 & 0 & 0 & 0 & 0 & 0 & 0 & 0 & 0 & 0 \\
\hline Microdon devius & 0 & 0 & 0 & 0 & 0 & 0 & 0 & 0 & 0 & 0 & 0 & 0 & 0 & 0 & 0 & 0 & 0 & 0 & 0 & 0 & 0 & 0 \\
\hline
\end{tabular}




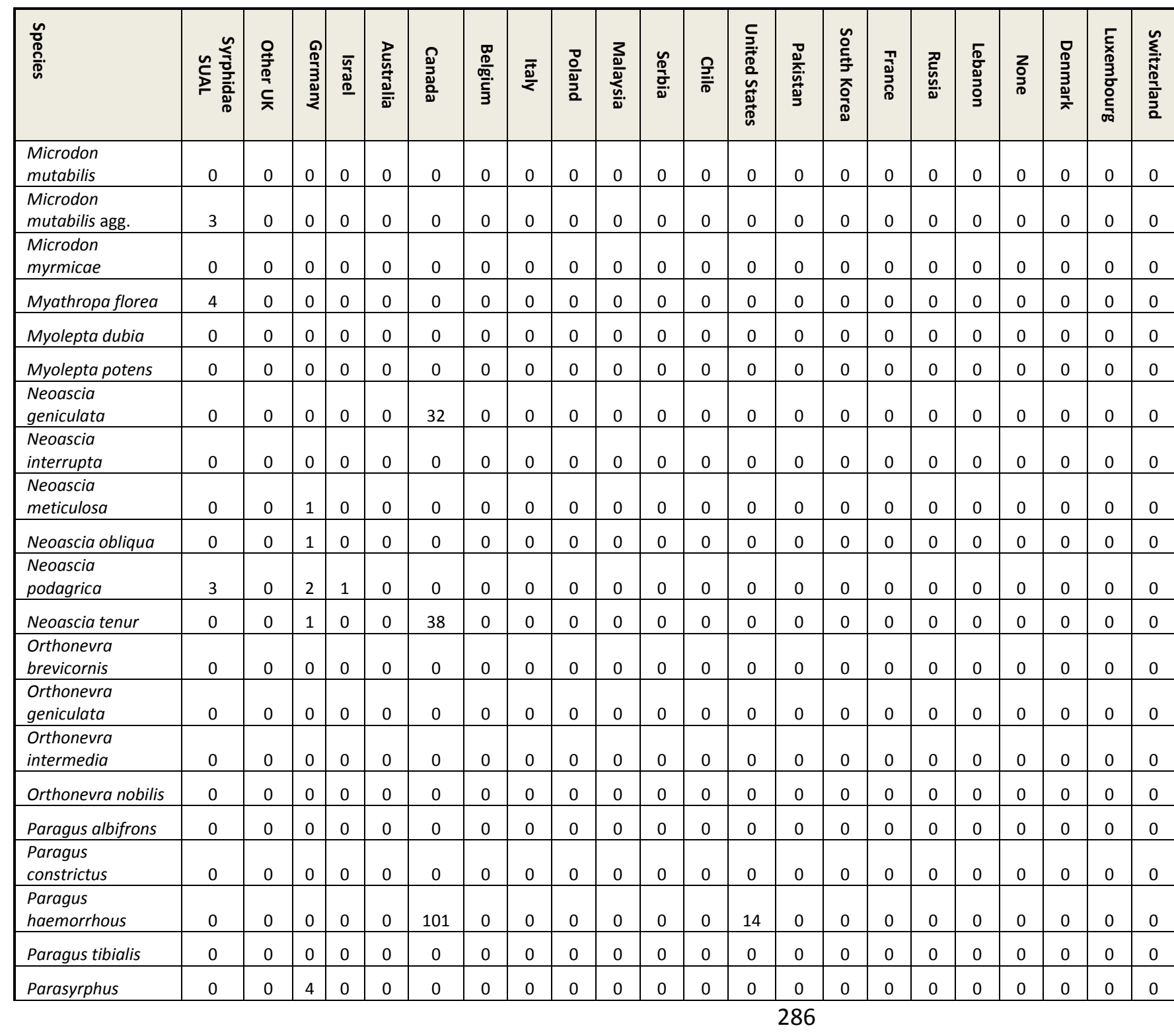




\begin{tabular}{|c|c|c|c|c|c|c|c|c|c|c|c|c|c|c|c|c|c|c|c|c|c|c|}
\hline $\begin{array}{l}\text { n } \\
\text { D } \\
\text { ก. }\end{array}$ & 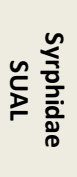 & 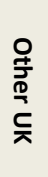 & $\begin{array}{l}\stackrel{Q}{D} \\
\stackrel{\mathbb{D}}{3} \\
3 \\
\stackrel{2}{\mathcal{D}} \\
\sum\end{array}$ & $\begin{array}{l}\overline{\underline{n}} \\
\stackrel{\Xi}{\Phi}\end{array}$ & 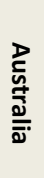 & $\begin{array}{l}\stackrel{2}{2} \\
\frac{2}{2} \\
\frac{0}{2}\end{array}$ & $\frac{\underset{D}{D}}{\frac{\mathbb{D}}{\sigma a}}$ & $\stackrel{\bar{\Phi}}{\gtrless}$ & 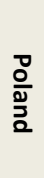 & $\begin{array}{l}\frac{3}{0} \\
\frac{\mathfrak{M}}{N} \\
\frac{0}{0}\end{array}$ & $\begin{array}{l}\frac{\mathscr{D}}{\frac{0}{0}} \\
\frac{0}{2}\end{array}$ & $\frac{\text { 울 }}{\overline{\bar{D}}}$ & 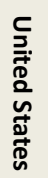 & 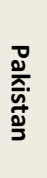 & 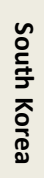 & 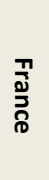 & 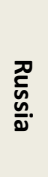 & 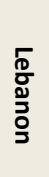 & $\frac{2}{o}$ & 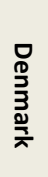 & 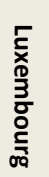 & 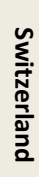 \\
\hline \multicolumn{23}{|l|}{ annulatus } \\
\hline $\begin{array}{l}\text { Parasyrphus } \\
\text { lineola }\end{array}$ & 0 & 0 & 0 & 0 & 0 & 0 & 0 & 0 & 0 & 0 & 0 & 0 & 0 & 0 & 0 & 0 & 0 & 0 & 0 & 0 & 0 & 0 \\
\hline $\begin{array}{l}\text { Parasyrphus } \\
\text { mallinellus }\end{array}$ & 0 & 0 & 0 & 0 & 0 & 0 & 0 & 0 & 0 & 0 & 0 & 0 & 0 & 0 & 0 & 0 & 0 & 0 & 0 & 0 & 0 & 0 \\
\hline $\begin{array}{l}\text { Parasyrphus } \\
\text { nigritarsis }\end{array}$ & 0 & 0 & 0 & 0 & 0 & 9 & 0 & 0 & 0 & 0 & 0 & 0 & 0 & 0 & 0 & 0 & 0 & 0 & 0 & 0 & 0 & 0 \\
\hline $\begin{array}{l}\text { Parasyrphus } \\
\text { punctulatus }\end{array}$ & 0 & 0 & 4 & 0 & 0 & 0 & 0 & 0 & 0 & 0 & 0 & 0 & 0 & 0 & 0 & 0 & 0 & 0 & 0 & 0 & 0 & 0 \\
\hline $\begin{array}{l}\text { Parasyrphus } \\
\text { vittiger }\end{array}$ & 0 & 0 & 1 & 0 & 0 & 0 & 0 & 0 & 0 & 0 & 0 & 0 & 0 & 0 & 0 & 0 & 0 & 0 & 0 & 0 & 0 & 0 \\
\hline $\begin{array}{l}\text { Parhelophilus } \\
\text { consimilis }\end{array}$ & 0 & 0 & 0 & 0 & 0 & 0 & 0 & 0 & 0 & 0 & 0 & 0 & 0 & 0 & 0 & 0 & 0 & 0 & 0 & 0 & 0 & 0 \\
\hline $\begin{array}{l}\text { Parhelophilus } \\
\text { frutetorum }\end{array}$ & 0 & 0 & 0 & 0 & 0 & 0 & 0 & 0 & 0 & 0 & 0 & 0 & 0 & 0 & 0 & 0 & 0 & 0 & 0 & 0 & 0 & 0 \\
\hline $\begin{array}{l}\text { Parhelophilus } \\
\text { versicolor }\end{array}$ & 0 & 0 & 0 & 0 & 0 & 0 & 0 & 0 & 0 & 0 & 0 & 0 & 0 & 0 & 0 & 0 & 0 & 0 & 0 & 0 & 0 & 0 \\
\hline $\begin{array}{l}\text { Pelecocera } \\
\text { caledonica }\end{array}$ & 0 & 0 & 0 & 0 & 0 & 0 & 0 & 0 & 0 & 0 & 0 & 0 & 0 & 0 & 0 & 0 & 0 & 0 & 0 & 0 & 0 & 0 \\
\hline $\begin{array}{l}\text { Pelecocera } \\
\text { scaevoides }\end{array}$ & 0 & 0 & 0 & 0 & 0 & 0 & 0 & 0 & 0 & 0 & 0 & 0 & 0 & 0 & 0 & 0 & 0 & 0 & 0 & 0 & 0 & 0 \\
\hline $\begin{array}{l}\text { Pelecocera } \\
\text { tricincta }\end{array}$ & 0 & 0 & 0 & 0 & 0 & 0 & 0 & 0 & 0 & 0 & 0 & 0 & 0 & 0 & 0 & 0 & 0 & 0 & 0 & 0 & 0 & 0 \\
\hline Pipiza austriaca & 0 & 0 & 0 & 0 & 0 & 0 & 0 & 0 & 0 & 0 & 0 & 0 & 0 & 0 & 0 & 0 & 0 & 0 & 0 & 0 & 0 & 0 \\
\hline Pipiza fasciata & 0 & 0 & 0 & 0 & 0 & 0 & 0 & 0 & 0 & 0 & 0 & 0 & 0 & 0 & 0 & 0 & 0 & 0 & 0 & 0 & 0 & 0 \\
\hline Pipiza festiva & 0 & 0 & 0 & 0 & 0 & 0 & 0 & 0 & 0 & 0 & 0 & 0 & 0 & 0 & 0 & 0 & 0 & 0 & 0 & 0 & 0 & 0 \\
\hline Pipiza lugubris & 0 & 0 & 0 & 0 & 0 & 0 & 0 & 0 & 0 & 0 & 0 & 0 & 0 & 0 & 0 & 0 & 0 & 0 & 0 & 0 & 0 & 0 \\
\hline Pipiza luteitarsis & 2 & 0 & 5 & 0 & 0 & 0 & 0 & 0 & 0 & 0 & 0 & 0 & 0 & 0 & 0 & 0 & 0 & 0 & 0 & 0 & 0 & 0 \\
\hline Pipiza noctiluca & 8 & 0 & 0 & 0 & 0 & 0 & 0 & 0 & 0 & 0 & 0 & 0 & 0 & 0 & 0 & 0 & 0 & 0 & 0 & 0 & 0 & 0 \\
\hline Pipiza notata & 0 & 0 & 0 & 0 & 0 & 0 & 0 & 0 & 0 & 0 & 0 & 0 & 0 & 0 & 0 & 0 & 0 & 0 & 0 & 0 & 0 & 0 \\
\hline $\begin{array}{l}\text { Pipizella } \\
\text { maculipennis }\end{array}$ & 0 & 0 & 0 & 0 & 0 & 0 & 0 & 0 & 0 & 0 & 0 & 0 & 0 & 0 & 0 & 0 & 0 & 0 & 0 & 0 & 0 & 0 \\
\hline Pipizella viduata & 4 & 0 & 0 & 0 & 0 & 0 & 0 & 0 & 0 & 0 & 0 & 0 & 0 & 0 & 0 & 0 & 0 & 0 & 0 & 0 & 0 & 0 \\
\hline
\end{tabular}




\begin{tabular}{|c|c|c|c|c|c|c|c|c|c|c|c|c|c|c|c|c|c|c|c|c|c|c|}
\hline $\begin{array}{l}\text { n } \\
\text { D } \\
\text { ก. } \\
\text { ฌ }\end{array}$ & 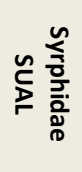 & 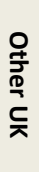 & $\begin{array}{l}\text { Q } \\
\stackrel{0}{3} \\
3 \\
\\
2\end{array}$ & 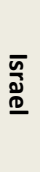 & 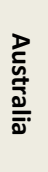 & 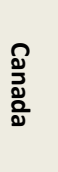 & 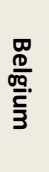 & $\stackrel{\bar{\Xi}}{\gtrless}$ & $\begin{array}{l}\text { 믈 } \\
\frac{0}{2} \\
2\end{array}$ & $\frac{3}{\frac{3}{0}}$ & $\begin{array}{l}\text { n } \\
\frac{D}{\frac{D}{0}}\end{array}$ & $\frac{\rho}{\bar{D}}$ & 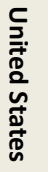 & 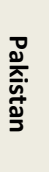 & 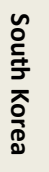 & 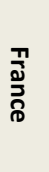 & 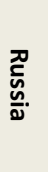 & \begin{tabular}{l} 
ס \\
$\frac{D}{0}$ \\
\multirow{2}{3}{} \\
0
\end{tabular} & $\underset{0}{2}$ & 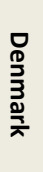 & 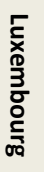 & 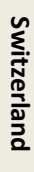 \\
\hline Pipizella virens & 0 & 0 & 0 & 0 & 0 & 0 & 0 & 0 & 0 & 0 & 0 & 0 & 0 & 0 & 0 & 0 & 0 & 0 & 0 & 0 & 0 & 0 \\
\hline $\begin{array}{l}\text { Platycheirus } \\
\text { albimanus }\end{array}$ & 2 & 0 & $\begin{array}{l}2 \\
9 \\
\end{array}$ & 0 & 0 & 8 & 0 & 0 & 0 & 0 & 0 & 0 & 0 & 0 & 0 & 0 & 0 & 0 & 0 & 0 & 0 & 0 \\
\hline $\begin{array}{l}\text { Platycheirus } \\
\text { ambiguus }\end{array}$ & 0 & 0 & 1 & 0 & 0 & 0 & 0 & 0 & 0 & 0 & 0 & 0 & 0 & 0 & 0 & 0 & 0 & 0 & 0 & 0 & 0 & 0 \\
\hline $\begin{array}{l}\text { Platycheirus } \\
\text { amplus }\end{array}$ & 0 & 0 & 0 & 0 & 0 & 1 & 0 & 0 & 0 & 0 & 0 & 0 & 1 & 0 & 0 & 0 & 0 & 0 & 0 & 0 & 0 & 0 \\
\hline $\begin{array}{l}\text { Platycheirus } \\
\text { angustatus }\end{array}$ & 0 & 0 & 0 & 0 & 0 & 6 & 0 & 0 & 0 & 0 & 0 & 0 & 0 & 0 & 0 & 0 & 1 & 0 & 0 & 0 & 0 & 0 \\
\hline $\begin{array}{l}\text { Platycheirus } \\
\text { aurolateralis }\end{array}$ & 0 & 0 & 0 & 0 & 0 & 0 & 0 & 0 & 0 & 0 & 0 & 0 & 0 & 0 & 0 & 0 & 0 & 0 & 0 & 0 & 0 & 0 \\
\hline $\begin{array}{l}\text { Platycheirus } \\
\text { clypeatus }\end{array}$ & 1 & 2 & 0 & 0 & 0 & 52 & 0 & 0 & 0 & 0 & 0 & 0 & 0 & 0 & 0 & 0 & 1 & 0 & 0 & 0 & 0 & 0 \\
\hline $\begin{array}{l}\text { Platycheirus } \\
\text { discimanus }\end{array}$ & 0 & 0 & 0 & 0 & 0 & 0 & 0 & 0 & 0 & 0 & 0 & 0 & 0 & 0 & 0 & 0 & 0 & 0 & 0 & 0 & 0 & 2 \\
\hline $\begin{array}{l}\text { Platycheirus } \\
\text { europaeus }\end{array}$ & 0 & 0 & 0 & 0 & 0 & 0 & 0 & 0 & 0 & 0 & 0 & 0 & 0 & 0 & 0 & 0 & 0 & 0 & 0 & 0 & 0 & 0 \\
\hline $\begin{array}{l}\text { Platycheirus } \\
\text { fulviventris }\end{array}$ & 4 & 0 & 2 & 0 & 0 & 0 & 0 & 0 & 0 & 0 & 0 & 0 & 0 & 0 & 0 & 0 & 0 & 0 & 0 & 0 & 0 & 0 \\
\hline $\begin{array}{l}\text { Platycheirus } \\
\text { granditarsis }\end{array}$ & 3 & 0 & 0 & 0 & 0 & 52 & 0 & 0 & 0 & 0 & 0 & 0 & 4 & 0 & 0 & 0 & 0 & 0 & 0 & 0 & 0 & 0 \\
\hline $\begin{array}{l}\text { Platycheirus } \\
\text { immarginatus }\end{array}$ & 0 & 0 & 0 & 0 & 0 & 0 & 0 & 0 & 0 & 0 & 0 & 0 & 0 & 0 & 0 & 0 & 0 & 0 & 0 & 0 & 0 & 0 \\
\hline $\begin{array}{l}\text { Platycheirus } \\
\text { manicatus }\end{array}$ & 3 & 0 & 0 & 0 & 0 & 0 & 0 & 0 & 0 & 0 & 0 & 0 & 0 & 0 & 0 & 0 & 1 & 0 & 0 & 0 & 0 & 2 \\
\hline $\begin{array}{l}\text { Platycheirus } \\
\text { melanopsis }\end{array}$ & 0 & 0 & 0 & 0 & 0 & 0 & 0 & 0 & 0 & 0 & 0 & 0 & 0 & 0 & 0 & 0 & 0 & 0 & 0 & 0 & 0 & 2 \\
\hline $\begin{array}{l}\text { Platycheirus } \\
\text { occultus }\end{array}$ & 0 & 0 & 0 & 0 & 0 & 0 & 0 & 0 & 0 & 0 & 0 & 0 & 0 & 0 & 0 & 0 & 0 & 0 & 0 & 0 & 1 & 1 \\
\hline $\begin{array}{l}\text { Platycheirus } \\
\text { peltatus }\end{array}$ & 2 & 0 & 3 & 0 & 0 & 0 & 0 & 0 & 0 & 0 & 0 & 0 & 0 & 0 & 0 & 0 & 4 & 0 & 0 & 0 & 0 & 0 \\
\hline $\begin{array}{l}\text { Platycheirus } \\
\text { perpallidus }\end{array}$ & 0 & 0 & 0 & 0 & 0 & 2 & 0 & 0 & 0 & 0 & 0 & 0 & 6 & 0 & 0 & 0 & 0 & 0 & 0 & 0 & 0 & 0 \\
\hline Platycheirus & 0 & 0 & 0 & 0 & 0 & 4 & 0 & 0 & 0 & 0 & 0 & 0 & 29 & 0 & 0 & 0 & 1 & 0 & 0 & 0 & 0 & 1 \\
\hline
\end{tabular}




\begin{tabular}{|c|c|c|c|c|c|c|c|c|c|c|c|c|c|c|c|c|c|c|c|c|c|c|}
\hline $\begin{array}{l}\widetilde{n} \\
\text { D } \\
\frac{0}{\Phi} .\end{array}$ & 号 & 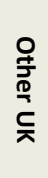 & $\begin{array}{l}\text { Q } \\
\stackrel{0}{3} \\
\stackrel{0}{3} \\
\stackrel{2}{2}\end{array}$ & $\begin{array}{l}\overline{\underline{n}} \\
\mathbb{\mathbb { D }} \\
\underline{\mathbb{D}}\end{array}$ & 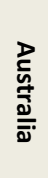 & $\begin{array}{l}\stackrel{8}{3} \\
\frac{2}{2}\end{array}$ & 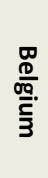 & $\stackrel{\bar{\Phi}}{<}$ & $\begin{array}{l}\frac{0}{2} \\
\frac{0}{20}\end{array}$ & $\frac{3}{\frac{3}{2}}$ & $\begin{array}{l}\tilde{\alpha} \\
\frac{0}{\frac{0}{\alpha}}\end{array}$ & $\frac{9}{\overline{\bar{D}}}$ & 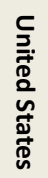 & 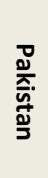 & 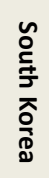 & 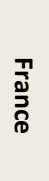 & 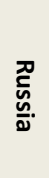 & $\begin{array}{l}5 \\
\frac{0}{0} \\
\frac{0}{2} \\
0 \\
0\end{array}$ & $\begin{array}{l}2 \\
\text { Z } \\
\stackrel{0}{0}\end{array}$ & $\begin{array}{l}\text { ס } \\
\stackrel{0}{3} \\
3 \\
\frac{2}{\lambda} \\
\frac{3}{\lambda}\end{array}$ & 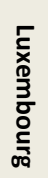 & 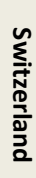 \\
\hline \multicolumn{23}{|l|}{ podagratus } \\
\hline $\begin{array}{l}\text { Platycheirus } \\
\text { ramsarensis }\end{array}$ & 0 & 0 & 0 & 0 & 0 & 0 & 0 & 0 & 0 & 0 & 0 & 0 & 0 & 0 & 0 & 0 & 0 & 0 & 0 & 0 & 0 & 0 \\
\hline $\begin{array}{l}\text { Platycheirus } \\
\text { rosarum }\end{array}$ & 3 & 0 & 3 & 0 & 0 & 26 & 0 & 0 & 0 & 0 & 0 & 0 & 0 & 0 & 0 & 0 & 0 & 0 & 0 & 1 & 0 & 0 \\
\hline $\begin{array}{l}\text { Platycheirus } \\
\text { scambus }\end{array}$ & 0 & 0 & 0 & 0 & 0 & 110 & 0 & 0 & 0 & 0 & 0 & 0 & 5 & 0 & 0 & 0 & 3 & 0 & 0 & 0 & 0 & 0 \\
\hline $\begin{array}{l}\text { Platycheirus } \\
\text { scutatus }\end{array}$ & 0 & 0 & 6 & 0 & 0 & 5 & 0 & 0 & 0 & 0 & 0 & 0 & 0 & 0 & 0 & 1 & 0 & 0 & 0 & 0 & 0 & 0 \\
\hline $\begin{array}{l}\text { Platycheirus } \\
\text { spendidus }\end{array}$ & 0 & 0 & 0 & 0 & 0 & 0 & 0 & 0 & 0 & 0 & 0 & 0 & 0 & 0 & 0 & 0 & 0 & 0 & 0 & 0 & 0 & 0 \\
\hline $\begin{array}{l}\text { Platycheirus } \\
\text { sticticus }\end{array}$ & 0 & 0 & 0 & 0 & 0 & 0 & 0 & 0 & 0 & 0 & 0 & 0 & 0 & 0 & 0 & 0 & 0 & 0 & 0 & 0 & 0 & 0 \\
\hline $\begin{array}{l}\text { Platycheirus } \\
\text { tarsalis }\end{array}$ & 1 & 0 & 0 & 0 & 0 & 0 & 1 & 0 & 0 & 0 & 0 & 0 & 0 & 0 & 0 & 0 & 0 & 0 & 0 & 0 & 0 & 0 \\
\hline Pocota personata & 0 & 0 & 0 & 0 & 0 & 0 & 0 & 0 & 0 & 0 & 0 & 0 & 0 & 0 & 0 & 0 & 0 & 0 & 0 & 0 & 0 & 0 \\
\hline $\begin{array}{l}\text { Portevinia } \\
\text { maculata }\end{array}$ & 4 & 0 & 0 & 0 & 0 & 0 & 0 & 0 & 0 & 0 & 0 & 0 & 0 & 0 & 0 & 0 & 0 & 0 & 0 & 0 & 0 & 0 \\
\hline Psilota anthracina & 0 & 0 & 0 & 0 & 0 & 0 & 0 & 0 & 0 & 0 & 0 & 0 & 0 & 0 & 0 & 0 & 0 & 0 & 0 & 0 & 0 & 0 \\
\hline Rhingia campestris & 4 & 0 & $\begin{array}{l}1 \\
3 \\
\end{array}$ & 0 & 0 & 0 & 0 & 0 & 0 & 0 & 0 & 0 & 0 & 0 & 0 & 0 & 0 & 0 & 0 & 0 & 0 & 0 \\
\hline Rhingia rostrata & 3 & 0 & 3 & 0 & 0 & 0 & 0 & 0 & 0 & 0 & 0 & 0 & 0 & 0 & 0 & 0 & 0 & 0 & 0 & 0 & 0 & 0 \\
\hline $\begin{array}{l}\text { Riponnensia } \\
\text { splendens }\end{array}$ & 0 & 0 & 0 & 0 & 0 & 0 & 0 & 0 & 0 & 0 & 0 & 0 & 0 & 0 & 0 & 0 & 0 & 0 & 0 & 0 & 0 & 0 \\
\hline $\begin{array}{l}\text { Scaeva } \\
\text { albomaculata }\end{array}$ & 0 & 0 & 0 & 0 & 0 & 0 & 0 & 0 & 0 & 0 & 0 & 0 & 0 & 0 & 0 & 0 & 0 & 0 & 0 & 0 & 0 & 0 \\
\hline Scaeva dignota & 0 & 0 & 0 & 0 & 0 & 0 & 0 & 0 & 0 & 0 & 0 & 0 & 0 & 0 & 0 & 0 & 0 & 0 & 0 & 0 & 0 & 0 \\
\hline $\begin{array}{l}\text { Scaeva } \\
\text { mecogramma }\end{array}$ & 0 & 0 & 0 & 0 & 0 & 0 & 0 & 0 & 0 & 0 & 0 & 0 & 0 & 0 & 0 & 0 & 0 & 0 & 0 & 0 & 0 & 0 \\
\hline Scaeva pyrastri & 4 & 0 & 4 & 0 & 0 & 17 & 0 & 0 & 0 & 0 & 0 & 0 & 1 & 0 & 0 & 0 & 1 & 0 & 0 & 0 & 0 & 0 \\
\hline Scaeva selenitica & 0 & 0 & 1 & 0 & 0 & 0 & 0 & 0 & 0 & 0 & 1 & 0 & 0 & 0 & 0 & 0 & 0 & 0 & 0 & 0 & 0 & 0 \\
\hline $\begin{array}{l}\text { Sericomyia } \\
\text { lappona }\end{array}$ & 3 & 0 & 0 & 0 & 0 & 0 & 0 & 0 & 0 & 0 & 0 & 0 & 0 & 0 & 0 & 0 & 1 & 0 & 0 & 0 & 0 & 0 \\
\hline
\end{tabular}




\begin{tabular}{|c|c|c|c|c|c|c|c|c|c|c|c|c|c|c|c|c|c|c|c|c|c|c|}
\hline 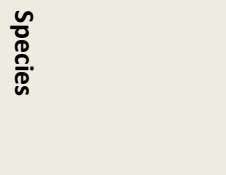 & 号 & 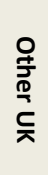 & 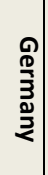 & $\begin{array}{l}\overline{\underline{n}} \\
\stackrel{\mathbb{D}}{\mathbb{D}} \\
\end{array}$ & 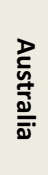 & $\begin{array}{l}\stackrel{8}{3} \\
\frac{2}{2}\end{array}$ & 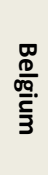 & $\frac{\bar{\Phi}}{2}$ & $\begin{array}{l}\frac{0}{2} \\
\frac{0}{20}\end{array}$ & $\frac{3}{\frac{3}{2}}$ & 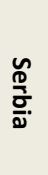 & $\frac{9}{\overline{\bar{D}}}$ & 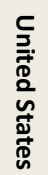 & 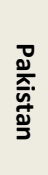 & 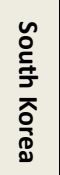 & 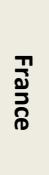 & 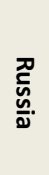 & $\begin{array}{l}5 \\
\frac{0}{0} \\
\frac{0}{2} \\
0 \\
0\end{array}$ & $\begin{array}{l}z \\
0 \\
\stackrel{0}{0}\end{array}$ & $\begin{array}{l}\text { ס } \\
\stackrel{0}{3} \\
3 \\
\frac{2}{\lambda} \\
\frac{3}{\lambda}\end{array}$ & 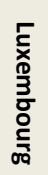 & 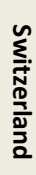 \\
\hline Sericomyia silentis & 4 & 0 & 1 & 0 & 0 & 0 & 0 & 0 & 0 & 0 & 0 & 0 & 0 & 0 & 0 & 0 & 0 & 0 & 0 & 0 & 0 & 0 \\
\hline $\begin{array}{l}\text { Sericomyia } \\
\text { superbiens }\end{array}$ & 4 & 0 & 0 & 0 & 0 & 0 & 0 & 0 & 0 & 0 & 0 & 0 & 0 & 0 & 0 & 0 & 0 & 0 & 0 & 0 & 0 & 0 \\
\hline $\begin{array}{l}\text { Sphaerophoria } \\
\text { bankowskae }\end{array}$ & 0 & 0 & 0 & 0 & 0 & 0 & 0 & 0 & 0 & 0 & 0 & 0 & 0 & 0 & 0 & 0 & 0 & 0 & 0 & 0 & 0 & 0 \\
\hline $\begin{array}{l}\text { Sphaerophoria } \\
\text { batava }\end{array}$ & 0 & 0 & 0 & 0 & 0 & 0 & 0 & 0 & 0 & 0 & 0 & 0 & 0 & 0 & 0 & 0 & 0 & 0 & 0 & 0 & 0 & 0 \\
\hline $\begin{array}{l}\text { Sphaerophoria } \\
\text { fatarum }\end{array}$ & 0 & 0 & 0 & 0 & 0 & 0 & 0 & 0 & 0 & 0 & 0 & 0 & 0 & 0 & 0 & 0 & 0 & 0 & 0 & 0 & 0 & 0 \\
\hline $\begin{array}{l}\text { Sphaerophoria } \\
\text { interrupta }\end{array}$ & 0 & 0 & 0 & 0 & 0 & 0 & 0 & 0 & 0 & 0 & 0 & 0 & 0 & 0 & 0 & 0 & 0 & 0 & 0 & 0 & 0 & 0 \\
\hline $\begin{array}{l}\text { Sphaerophoria } \\
\text { loewi }\end{array}$ & 0 & 0 & 0 & 0 & 0 & 0 & 0 & 0 & 0 & 0 & 0 & 0 & 0 & 0 & 0 & 0 & 0 & 0 & 0 & 0 & 0 & 0 \\
\hline $\begin{array}{l}\text { Sphaerophoria } \\
\text { philanthus }\end{array}$ & 0 & 0 & 0 & 0 & 0 & 29 & 0 & 0 & 0 & 0 & 0 & 0 & 3 & 0 & 0 & 0 & 0 & 0 & 0 & 0 & 0 & 0 \\
\hline $\begin{array}{l}\text { Sphaerophoria } \\
\text { potentillae }\end{array}$ & 0 & 0 & 0 & 0 & 0 & 0 & 0 & 0 & 0 & 0 & 0 & 0 & 0 & 0 & 0 & 0 & 0 & 0 & 0 & 0 & 0 & 0 \\
\hline $\begin{array}{l}\text { Sphaerophoria } \\
\text { rueppellii }\end{array}$ & 0 & 0 & 0 & 0 & 0 & 0 & 0 & 0 & 0 & 0 & 0 & 0 & 0 & 0 & 0 & 0 & 0 & 0 & 0 & 0 & 0 & 0 \\
\hline $\begin{array}{l}\text { Sphaerophoria } \\
\text { scripta }\end{array}$ & 1 & 0 & 0 & 0 & 0 & 1 & 0 & 0 & 0 & 0 & 0 & 0 & 0 & 0 & 0 & 0 & 0 & 1 & 0 & 0 & 0 & 0 \\
\hline $\begin{array}{l}\text { Sphaerophoria } \\
\text { taeniata }\end{array}$ & 0 & 0 & 0 & 0 & 0 & 0 & 0 & 0 & 0 & 0 & 0 & 0 & 0 & 0 & 0 & 0 & 0 & 0 & 0 & 0 & 0 & 0 \\
\hline $\begin{array}{l}\text { Sphaerophoria } \\
\text { virgata }\end{array}$ & 0 & 0 & 0 & 0 & 0 & 0 & 0 & 0 & 0 & 0 & 0 & 0 & 0 & 0 & 0 & 0 & 0 & 0 & 0 & 0 & 0 & 0 \\
\hline Sphegina clunipes & 1 & 0 & 0 & 0 & 0 & 0 & 0 & 0 & 0 & 0 & 0 & 0 & 0 & 0 & 0 & 0 & 0 & 0 & 0 & 0 & 0 & 0 \\
\hline Sphegina elegans & 0 & 0 & 0 & 0 & 0 & 0 & 0 & 0 & 0 & 0 & 0 & 0 & 0 & 0 & 0 & 0 & 0 & 0 & 0 & 0 & 0 & 0 \\
\hline Sphegina sibirica & 0 & 0 & 0 & 0 & 0 & 0 & 0 & 0 & 0 & 0 & 0 & 0 & 0 & 0 & 0 & 0 & 0 & 0 & 0 & 0 & 0 & 0 \\
\hline $\begin{array}{l}\text { Sphegina } \\
\text { verecunda }\end{array}$ & 0 & 0 & 0 & 0 & 0 & 0 & 0 & 0 & 0 & 0 & 0 & 0 & 0 & 0 & 0 & 0 & 0 & 0 & 0 & 0 & 0 & 0 \\
\hline Syritta pipiens & 1 & 0 & 1 & 0 & 0 & 18 & 0 & 0 & 0 & 0 & 0 & 0 & 9 & 0 & 0 & 0 & 0 & 0 & 0 & 0 & 0 & 0 \\
\hline Syrphus nitidifrons & 0 & 0 & 0 & 0 & 0 & 0 & 0 & 0 & 0 & 0 & 0 & 0 & 0 & 0 & 0 & 0 & 0 & 0 & 0 & 0 & 0 & 0 \\
\hline Syrphus rectus & 0 & 0 & 0 & 0 & 0 & 5 & 0 & 0 & 0 & 0 & 0 & 0 & 1 & 0 & 0 & 0 & 0 & 0 & 0 & 0 & 0 & 0 \\
\hline
\end{tabular}




\begin{tabular}{|c|c|c|c|c|c|c|c|c|c|c|c|c|c|c|c|c|c|c|c|c|c|c|}
\hline 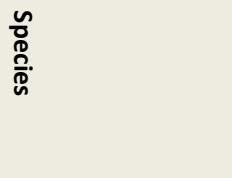 & 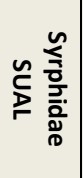 & $\begin{array}{l}\text { 올 } \\
\stackrel{+}{\overline{0}} \\
\stackrel{0}{c} \\
\text { 듯 }\end{array}$ & \begin{tabular}{l}
$\stackrel{Q}{0}$ \\
$\stackrel{0}{3}$ \\
\multirow{3}{0}{} \\
$\stackrel{2}{2}$
\end{tabular} & $\begin{array}{l}\overline{\mathbf{n}} \\
\bar{D} \\
\underline{0}\end{array}$ & 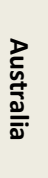 & $\begin{array}{l}\stackrel{8}{2} \\
\frac{\mathscr{2}}{2}\end{array}$ & 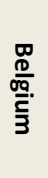 & $\stackrel{\bar{\Phi}}{\gtrless}$ & $\begin{array}{l}\frac{0}{0} \\
\frac{0}{2} \\
\text { בे }\end{array}$ & $\frac{3}{\frac{3}{2}}$ & $\begin{array}{l}\tilde{D} \\
\frac{D}{\frac{\sigma}{v}} \\
\frac{0}{0}\end{array}$ & $\frac{\text { 울 }}{\overline{1}}$ & 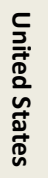 & 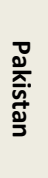 & 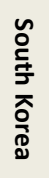 & $\begin{array}{l}\frac{T}{3} \\
\stackrel{2}{3} \\
\stackrel{0}{0}\end{array}$ & 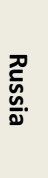 & $\begin{array}{l}\sqrt[5]{0} \\
\stackrel{0}{0} \\
\frac{0}{3} \\
0\end{array}$ & $\begin{array}{l}z \\
0 \\
0 \\
0\end{array}$ & 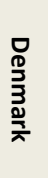 & 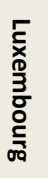 & 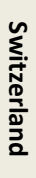 \\
\hline Syrphus ribesii & 3 & 0 & 5 & 0 & 0 & 127 & 0 & 0 & 0 & 0 & 0 & 0 & 2 & 0 & 0 & 0 & 0 & 0 & 0 & 0 & 0 & 0 \\
\hline Syrphus torvus & 3 & 0 & 1 & 0 & 0 & 57 & 0 & 0 & 0 & 0 & 0 & 0 & 0 & 0 & 0 & 0 & 0 & 0 & 0 & 0 & 0 & 0 \\
\hline Syrphus vitripennis & 4 & 0 & 4 & 0 & 0 & 13 & 0 & 0 & 0 & 0 & 0 & 0 & 1 & 0 & 0 & 0 & 0 & 0 & 0 & 0 & 0 & 0 \\
\hline $\begin{array}{l}\text { Trichopsomyia } \\
\text { flavitarsis }\end{array}$ & 0 & 0 & 0 & 0 & 0 & 0 & 0 & 0 & 0 & 0 & 0 & 0 & 0 & 0 & 0 & 0 & 0 & 0 & 0 & 0 & 0 & 0 \\
\hline $\begin{array}{l}\text { Trichopsomyia } \\
\text { lucida }\end{array}$ & 0 & 0 & 0 & 0 & 0 & 0 & 0 & 0 & 0 & 0 & 0 & 0 & 0 & 0 & 0 & 0 & 0 & 0 & 0 & 0 & 0 & 0 \\
\hline Triglyphus primus & 0 & 0 & 1 & 0 & 0 & 0 & 0 & 0 & 0 & 0 & 0 & 0 & 0 & 0 & 0 & 0 & 0 & 0 & 0 & 0 & 0 & 0 \\
\hline Tropidia scita & 3 & 0 & 0 & 0 & 0 & 0 & 0 & 0 & 0 & 0 & 0 & 0 & 0 & 0 & 0 & 0 & 0 & 0 & 0 & 0 & 0 & 0 \\
\hline $\begin{array}{l}\text { Volucella } \\
\text { bombylans }\end{array}$ & 4 & 0 & 0 & 0 & 0 & 0 & 0 & 0 & 0 & 0 & 0 & 0 & 2 & 0 & 0 & 0 & 0 & 0 & 0 & 0 & 0 & 0 \\
\hline Volucella inanis & 0 & 0 & 7 & 0 & 0 & 0 & 0 & 0 & 0 & 0 & 0 & 0 & 0 & 0 & 0 & 0 & 0 & 0 & 0 & 0 & 0 & 0 \\
\hline Volucella inflata & 2 & 0 & 0 & 0 & 0 & 0 & 0 & 0 & 0 & 0 & 0 & 0 & 0 & 0 & 0 & 0 & 0 & 0 & 0 & 0 & 0 & 0 \\
\hline Volucella pellucens & 1 & 0 & 6 & 0 & 0 & 0 & 0 & 0 & 0 & 0 & 0 & 0 & 0 & 0 & 0 & 0 & 0 & 0 & 0 & 0 & 0 & 0 \\
\hline Volucella zonaria & 0 & 0 & 2 & 0 & 0 & 0 & 0 & 0 & 0 & 0 & 0 & 0 & 0 & 0 & 0 & 0 & 0 & 0 & 0 & 0 & 0 & 0 \\
\hline $\begin{array}{l}\text { Xanthandrus } \\
\text { comtus }\end{array}$ & 0 & 0 & 0 & 0 & 0 & 0 & 0 & 0 & 0 & 0 & 0 & 0 & 0 & 0 & 0 & 0 & 0 & 0 & 0 & 0 & 0 & 0 \\
\hline $\begin{array}{l}\text { Xanthogramma } \\
\text { citrofasciatum }\end{array}$ & 0 & 0 & 0 & 0 & 0 & 0 & 0 & 0 & 0 & 0 & 0 & 0 & 0 & 0 & 0 & 0 & 0 & 0 & 0 & 0 & 0 & 0 \\
\hline $\begin{array}{l}\text { Xanthogramma } \\
\text { pedissequum }\end{array}$ & 0 & 0 & 0 & 0 & 0 & 0 & 0 & 0 & 0 & 0 & 0 & 0 & 0 & 0 & 0 & 0 & 0 & 0 & 0 & 0 & 0 & 0 \\
\hline $\begin{array}{l}\text { Xanthogramma } \\
\text { stackelbergi }\end{array}$ & 0 & 0 & 0 & 0 & 0 & 0 & 0 & 0 & 0 & 0 & 0 & 0 & 0 & 0 & 0 & 0 & 0 & 0 & 0 & 0 & 0 & 0 \\
\hline Xylota abiens & 0 & 0 & 0 & 0 & 0 & 0 & 0 & 0 & 0 & 0 & 0 & 0 & 0 & 0 & 0 & 0 & 0 & 0 & 0 & 0 & 0 & 0 \\
\hline Xylota florum & 0 & 0 & 0 & 0 & 0 & 0 & 0 & 0 & 0 & 0 & 0 & 0 & 0 & 0 & 0 & 0 & 0 & 0 & 0 & 0 & 0 & 0 \\
\hline Xylota jakutorum & 0 & 0 & 2 & 0 & 0 & 0 & 0 & 0 & 0 & 0 & 0 & 0 & 0 & 0 & 0 & 0 & 0 & 0 & 0 & 0 & 0 & 0 \\
\hline Xylota segnis & 4 & 0 & $\begin{array}{l}1 \\
4 \\
\end{array}$ & 0 & 0 & 1 & 0 & 0 & 0 & 0 & 0 & 0 & 0 & 0 & 0 & 0 & 0 & 0 & 0 & 0 & 0 & 0 \\
\hline Xylota sylvarum & 0 & 0 & 2 & 0 & 0 & 0 & 0 & 0 & 0 & 0 & 0 & 0 & 0 & 0 & 0 & 0 & 0 & 0 & 0 & 0 & 0 & 0 \\
\hline Xylota tarda & 0 & 0 & 0 & 0 & 0 & 0 & 0 & 0 & 0 & 0 & 0 & 0 & 0 & 0 & 0 & 0 & 0 & 0 & 0 & 0 & 0 & 0 \\
\hline
\end{tabular}




\begin{tabular}{|c|c|c|c|c|c|c|c|c|c|c|c|c|c|c|c|c|c|c|c|c|c|c|}
\hline $\begin{array}{l}\frac{n}{0} \\
\frac{\infty}{0} \\
\frac{2}{\Phi} .\end{array}$ & 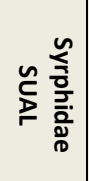 & 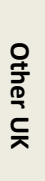 & 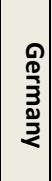 & $\begin{array}{l}\overline{\overline{\underline{D}}} \\
\underline{\underline{D}} \\
\underline{\underline{D}}\end{array}$ & 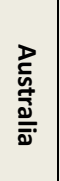 & 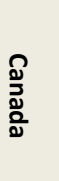 & 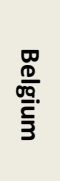 & $\stackrel{\overline{\tilde{D}}}{2}$ & $\begin{array}{l}\frac{0}{0} \\
\frac{0}{2}\end{array}$ & $\begin{array}{l}\frac{3}{2} \\
\frac{2}{2} \\
\frac{\underline{a}}{2}\end{array}$ & $\begin{array}{l}\frac{\widetilde{o}}{\frac{0}{\sigma}} \\
\frac{\sigma}{v}\end{array}$ & ?ํ. & 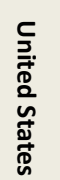 & 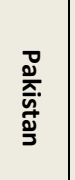 & 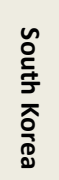 & 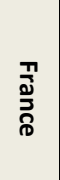 & 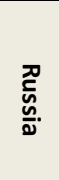 & 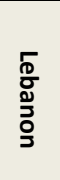 & $\begin{array}{l}z \\
\text { zo } \\
\stackrel{0}{0}\end{array}$ & 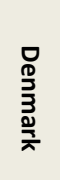 & 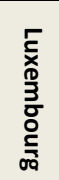 & 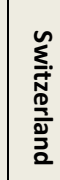 \\
\hline $\begin{array}{l}\text { Xylota } \\
\text { xanthocnema }\end{array}$ & 0 & 0 & 0 & 0 & 0 & 0 & 0 & 0 & 0 & 0 & 0 & 0 & 0 & 0 & 0 & 0 & 0 & 0 & 0 & 0 & 0 & 0 \\
\hline Total & 256 & 3 & $\begin{array}{l}4 \\
3 \\
6 \\
\end{array}$ & 2 & 2 & $\begin{array}{c}132 \\
4\end{array}$ & 1 & 1 & 1 & 6 & 7 & 1 & $\begin{array}{c}14 \\
7 \\
\end{array}$ & $\begin{array}{c}10 \\
4 \\
\end{array}$ & 8 & 2 & 13 & 1 & 0 & 1 & 1 & 8 \\
\hline
\end{tabular}


Chapter 5 Appendix 1 Study site names, study site codes, location, area and altitude

\begin{tabular}{|c|c|c|c|c|c|c|}
\hline Site Name & Site Code & $\begin{array}{c}\text { British National Grid } \\
\text { Reference }\end{array}$ & Latitude & Longitude & $\begin{array}{c}\text { Area } \\
\text { (ha) }\end{array}$ & $\begin{array}{c}\text { Altitude } \\
\text { (m) }\end{array}$ \\
\hline $\begin{array}{c}\text { Rhosydd Castell Du a } \\
\text { Phlas y Betws }\end{array}$ & CAD & SN654117 & 51.787718 & 3.9528712 & 1.79 & 155 \\
\hline $\begin{array}{c}\text { Caeau Heol y Llidiart } \\
\text { Coch }\end{array}$ & LLC & SN711213 & 51.875328 & 3.8738581 & 0.4 & 209 \\
\hline Rhos Cruglas & RHC & SN683240 & 51.898935 & 3.9155394 & 3.7 & 170 \\
\hline Caeau Tir Mawr & TRE & SN650205 & 51.866695 & 3.9621013 & 2.8 & 193 \\
\hline
\end{tabular}

Chapter 6 Appendix 1 Study site names, study site codes, location, area and altitude

\begin{tabular}{|c|c|c|c|c|c|c|}
\hline Site Name & Site Code & $\begin{array}{c}\text { British National Grid } \\
\text { Reference }\end{array}$ & Latitude & Longitude & $\begin{array}{c}\text { Area } \\
\text { (ha) }\end{array}$ & $\begin{array}{c}\text { Altitude } \\
\text { (m) }\end{array}$ \\
\hline $\begin{array}{c}\text { Rhosydd Castell Du a } \\
\text { Phlas y Betws }\end{array}$ & CAD & SN654117 & 51.787718 & 3.9528712 & 1.79 & 155 \\
\hline $\begin{array}{c}\text { Caeau Heol y Llidiart } \\
\text { Coch }\end{array}$ & LLC & SN711213 & 51.875328 & 3.8738581 & 0.4 & 209 \\
\hline \begin{tabular}{c} 
Caeau Tir Mawr \\
\hline
\end{tabular} & TRE & SN650205 & 51.866695 & 3.9621013 & 2.8 & 193 \\
\hline
\end{tabular}

